LBNL-56668

$\mathrm{UC}-\mathbf{x x x x}$

\title{
Wetland Plant Guide for Assessing Habitat Impacts of Real-Time Salinity Management
}

\author{
Nigel W.T. Quinn PhD, P.E. \\ Sara A. Feldmann \\ HydroEcological Engineering Advanced Decision Support \\ Lawrence Berkeley National Laboratory \\ 1 Cyclotron Road, 70A-3317H \\ Berkeley, CA 94720
}

November 15, 2004 


\section{ACKNOWLEDGEMENTS}

This project was supported by the CALFED Ecosystem Restoration Program and administered by the US Bureau of Reclamation under U.S. Department of Interior Interagency Agreement No. 3-AA-20-10970, through US Department of Energy Contract No. DE-AC03-76SF00098. The first author would like to thank CALFED and the US Bureau of Reclamation for their financial support and in particular Ms Diane Buzzard, the project COTR, who provided excellent support and was able to secure funds for additional work in the last year of the project.

Sara Feldmann was responsible for the majority of effort in producing this wetland plant identification guide. Sara came to LBNL as a summer intern and became a research technician during her 12 month employment at LBNL. Her success in producing this guide is in large part attributable to the cooperation and assistance provided by Tim Poole, Wetland Manager at the Salinas Land and Cattle Club and Brandon Jordan, Wetland Biologist at the San Luis National Wildlife Refuge. Their effort has resulted in a document that we think will advance science-based wetland habitat management in the Grasslands Ecological Area. 


\begin{abstract}
This wetland plant guide was developed to aid moist soil plant identification and to assist in the mapping of waterfowl and shorebird habitat in the Grassland Water District and surrounding wetland areas. The motivation for this habitat mapping project was a concern that real-time salinity management of wetland drainage might have long-term consequences for wildfowl habitat health - changes in wetland drawdown schedules might, over the long term, lead to increased soil salinity and other conditions unfavorable to propagation of the most desirable moist soil plants. Hence, the implementation of a program to monitor annual changes in the most common moist soil plants might serve as an index of habitat health and sustainability. Our review of the current scientific and popular literature failed to identify a good, comprehensive field guide that could be used to calibrate and verify high resolution remote sensing imagery, that we had started to use to develop maps of wetland moist soil plants in the Grassland Water District. Since completing the guide it has been used to conduct ground truthing field surveys using the California Native Plant Society methodology in 2004. Results of this survey and a previous wetland plant survey in 2003 are published in a companion LBNL publication summarizing 4 years of fieldwork to advance the science of real-time wetland salinity management.
\end{abstract}




\section{INTRODUCTION}

The Grasslands Ecological Area (GEA) is comprised of 178,000 acres of wetlands in the Central Valley of California and includes federally, state and privately owned land ${ }^{1}$. The primary forces protecting these wetlands are the organizations serving the duck hunters that are drawn to them October to January every year for recreation and sport. GEA wetlands are a hot spot on the Pacific Flyway, each year attracting over 200,000 shorebirds and more than twice that number of ducks ${ }^{2}$. Aerial counts in January 2004 estimated the GEA duck population at $583,000^{3}$.

Many hunters have what has aptly been described as a love-love relationship with the waterfowl that rely on these wetlands. They work to protect and nurture habitat for them in the off-season and they shoot and eat them during hunting season. Depending on your viewpoint, this relationship may be difficult to reconcile, but it informs the perspective that keeps the last five percent of California's historic wetlands prosperous and supporting wildlife despite a premium on the State's water resources.

The remnants of the Central Valley's wetlands are now "managed," which means they are sustained through human-made canals, controlled inlets and outlets, as well as contracts for water with the U.S. Bureau of Reclamation. Years of diverting the San Joaquin and Merced Rivers for the purposes of agriculture and urban development have terminated natural delivery of water to millions of acres of land that formerly served as

\footnotetext{
${ }^{1}$ Grassland Water District. July 2001. Land Use and Economics Study, Grassland Ecological Area. Merced County, CA. Prepared by Karen Weissman of Thomas Reid Associates.

${ }^{2}$ Western Hemisphere Shorebird Reserve Network. 2004. http://www.manomet.org/WHSRN/

${ }^{3}$ Grassland Water District. May/June 2004. Grassland Today. vol. 14, no. 3.
} 
river floodplains. In the past, river levels would seasonally rise, flowing over channel banks and flooding vast areas of the valley floor, supporting shallow seasonal marshes, permanent ponds, lakes and sloughs, as well as riparian habitat ${ }^{4}$. Today, only a fraction of California's original floodplains are managed as wetlands, and competition for land and water resources continues to threaten that which remains.

Many years of negotiations over water rights, involving parties with conflicting priorities, have resulted in complex State water politics. High demand for clean water continues to perpetuate competition among all major consumers and heightens concern about how water usage impacts water quality. Water is often used multiple times as it travels through the State's delivery and drainage infrastructure, so chemical nutrients and salts that enter the system at any point upstream affect users downstream. For instance, farmers lose productivity when the water they rely on for irrigation is salty. Plants become stressed because normal osmotic processes that allow them to take up available water are disrupted by the increased concentration of salts. This is particularly problematic during seed germination when crop roots are small and especially vulnerable to impaired soil and moisture conditions.

While the reasons for and problems stemming from contamination of water supplies are varied and broad, salt management is the paramount issue for wetland managers in the Central Valley. Spring drawdown - the seasonal draining of wetlands into the San Joaquin River - occurs during a period that coincides with crop germination and the most

\footnotetext{
${ }^{4}$ U.S. Department of the Interior, Bureau of Reclamation. July 1997. San Joaquin Basin Action Plan and North Grasslands Area Draft Environmental Assessment/Initial Study.
} 
essential agricultural irrigation of the season. Unfortunately, wetland drawdown does have the effect of increasing salt loads in the San Joaquin River. To some extent this is unavoidable because water supplied to the wetlands during the fall and winter comes primarily from the delta and is already somewhat salty, and is made saltier by the naturally saline soils and evaporation of water from pond surfaces during the months that the wetlands are flooded.

In recent years, total maximum daily loads (TMDLs) have been introduced by the Environmental Protection Agency and enforced locally by State and Regional Water Quality Control Boards in an effort to limit entry of a variety of contaminants into the State's water supply, including salts that come from brackish wetlands. Wetland managers are under pressure to monitor their releases and carefully assess management practices to maximize wetland function while minimizing environmental impact.

Fortunately there are management practices that affect the extent to which salts concentrate and/or pose problems for farmers downstream. Included among these are duration and timing of drawdown. If a pond is drained slowly, more salts will be left on the soil surface and less will be drawn into the River. While this is obviously preferable for the farmer downstream and state regulators, it is not necessarily good for germination of desirable moist-soil plants. Alternatively, drawdown can be done earlier or later in the season to bypass critical irrigation time, but this too impacts vegetation. 
In order to accurately assess the impact of drawdown practices on water as well as habitat quality, monitoring and quantification techniques must be tested and refined. As part of this process, water quality monitoring stations have been designed and built for real-time measurement of temperature, flow and electrical conductivity. Current monitoring efforts are underway at six locations in North Grasslands Water District and four locations in the San Luis National Wildlife Refuge. These locations were selected because they serve as the primary inlets and outlets for water entering and leaving the system in both North Grasslands and the Refuge.

While having information related to water quality is essential, it is not sufficient for wetlands management. Providing nutritious food and sufficient habitat for waterfowl remains a priority for wetland managers, so wetlands management based on releasing clean water into the River needs to be balanced with credible data ensuring that suitable growing conditions for the desired abundance and richness of plant species are not being compromised.

Vegetation is an important indicator of wetland health and determines the viability of an area to support waterfowl. Certain species of moist soil plants produce nutritious seeds or attract various invertebrates that serve as a protein-rich food source, either on land, or submerged after flood-up in the fall. Upland areas are also important, in that they provide habitat and locations for nesting. Wetland managers understand and manage for the right balance of the right plant species in order to attract a large and diverse population of shorebirds and ducks. For example, waterfowl have varying tolerances for density and 
height of vegetation. Wood ducks, mallards and blue-winged teal use habitats with dense vegetation, whereas northern pintails prefer shallow, open habitats with high visibility and sparse vegetation ${ }^{5}$.

In order to effectively balance these competing objectives for clean water and productive wetlands, the nature of the relationship between management practices and these outcomes must be more clearly understood. Vegetation response to various changes in management can be anticipated only through ongoing, consistent measurement and analysis. There are many other factors, including weather variability and environmental disturbances, which also need to be understood before conclusions can be drawn relating specific management strategies to changes in vegetation. So, to complement the ongoing supply of real-time water quality data, plant communities and vegetation densities need to be measured, mapped and tracked from year to year.

For an area as large as Grasslands, traditional vegetation monitoring techniques such as line intercept, point count and quadrats, would be prohibitively expensive or impractical to conduct every year given human resource constraints. For this reason, efforts are underway to determine the potential of using high-resolution satellite imagery and statistical classification techniques to identify and map plant communities. Satellite imaging technology has advanced rapidly in recent years. Private enterprise has made available imagery with resolutions exceeding one square meter. For this project, multispectral imagery was purchased from Digital Globe with 2.4 meter spatial resolution in

\footnotetext{
${ }^{5}$ Fredrickson, Leigh H. and Reid, Frederic A. 1998. Waterfowl Management Handbook, Gaylord Memorial Laboratory. School of Forestry, Fisheries and Wildlife. University of Missouri-Columbia. Puxico, MO 63960 .
} 
red, blue, green and near-infrared bands and a panchromatic image with $60 \mathrm{~cm}$ spatial resolution. Each band captures an image based on reflectance of light between defined wavelengths in the electromagnetic spectrum. Sophisticated computer applications are then used to view the image and correlate ground information with spectral data. If a strong correlation is found, a remote sensing specialist can perform an image classification that pulls out the spectral signatures that distinguish between plant communities as well as land and water features.

Since the full potential and limitations of this technique are still in question, initial efforts to do this are focused on a smaller area that includes the San Luis Unit of the San Luis National Wildlife Refuge and a private duck club in North Grasslands, a combined area of approximately 9,000 acres.

Methodical and extensive ground surveying is critical to using remote sensing technology, as field data forms the basis for conducting and validating image classification. The process used for gathering field data was modeled from the California Native Plant Society's rapid assessment protocol, a reconnaissance-level method of vegetation and habitat sampling ${ }^{6}$. Using this methodology, information was collected about plant communities, including size, geographic location, species composition and distribution, vegetation density and soil properties.

Moist soil plants grow and mature quickly after spring drawdown, so ground surveying was carried out over the entire area of interest during the two-week period immediately

\footnotetext{
${ }^{6}$ California Native Plant Society. 2004. http://www.cnps.org/
} 
preceding and following the date of image collection. For optimal time management, field survey crews had to be equipped with the tools and knowledge for rapid habitat assessments. For this project, with a small team and no trained botanists on staff, a field guide was necessary that would make field identification of plants as simple as possible. The following Wetland Plant Guide was created to serve this purpose.

\section{METHODOLOGY}

The guide contains moist soil, emergent and upland plants known or believed to exist in Central Valley wetlands. An effort was made to include as many of these species as possible. Those not included were omitted due to lack of available data or uncertain identification.

The guide is organized alphabetically by scientific name. Although many people do not know Latin names, attempts to organize the manual by common name or plant type proved complicating and ineffective. Common names are used inconsistently; with one name referring to multiple species and one species often associated with many common names. For instance, in a search for information about Echinochloa crusgalli, one user might look for a plant called Watergrass and another for Barnyardgrass. While it may have been possible to include most of the common names in the guide, navigating through an all-inclusive Table of Contents would have been tedious and confusing.

Consideration was also given for organizing the guide by plant type or morphology, but it proved difficult to define logical groupings that were appropriate in size and distribution, 
so as to break the content into more manageable pieces. It was also a priority that groups not overlap or assume botanical knowledge on the part of the user. A group distinguished by species that have flowers with petals, for example, might seem like a straight-forward grouping, but if a user of the guide is looking at a pre-bloom seedling of a Frankenia salina, the grouping flowers with petals does not reveal information that will lead the user there for details about this species that when mature has small flowers with pink petals.

In summary, it was through a process of elimination that the decision was made to organize the guide by Latin name. While it may prove frustrating for some users at first, it seemed the most simple and accurate way to present the information.

Each page of the guide contains a description and images related to one species or a genus. There are relatively few genera-level pages. They were only created if the correct species was unknown or if multiple species from the same genus are likely to be found in Central Valley wetlands and are similar enough to be grouped together. Distinguishing very similar species is not a priority of this project nor is it realistic with current multispectral satellite or image processing technology. In the event that multiple species from the same genus are represented in the wetlands and one or more of those species is markedly different from the others, a separate page was created. Such is the case with Scirpus maritimus. There are multiple Scirpus species found in the wetlands, but $S$. maritimus is much smaller and is found in communities distinct from other members of the genus. 
Approximately one quarter or every page is dedicated to a bulleted text description of the plant being profiled. For easier reference in the field, the content is divided into three sections: stems, leaves and inflorescence. Descriptions are relatively simple and generally avoid details that would require magnification to see or a trained botanist to understand. The vast majority of the content for this section came from The Jepson Manual: Higher Plants of California.

The remaining three quarters of each page is reserved for a few carefully selected images. Images were chosen to highlight different parts of the plant or to emphasize distinguishing characteristics. For example, Polygonum species have distinctly swollen nodes (where the leaf meets the stem), so an image was included of Polygonum lapathifolium in which this quality is clearly visible. That said, a diverse collection of high quality images was not found for every species and these choices were obviously dependent on the options available.

The back of the guide contains sketches, including a diagram of grass structure and illustrations from The Jepson Manual that display common leaf and flower shapes. Following the illustrations section is a short glossary defining technical terminology used in the guide. Efforts were made to keep use of technical terms to a minimum, but space constraints required using some pithy botanical terms so as to avoid the much longer descriptions often needed to convey the same meaning. In some cases, definitions are 
complemented with an illustration in the previous section. Such instances are noted in the glossary next to the appropriate term.

All images contained in the guide were taken from Internet sources and are not the project team's artistic work. Shortly after the need for a guide became apparent, there was discussion about bringing a camera to Grasslands and taking pictures of wetland plants that could then be compiled for the project field guide. This suggestion was ultimately rejected for a couple of reasons. One is that good photography requires time and skill, and given this, would have been a costly diversion from the objectives of the project. In the few amateur plant pictures taken early on, it is difficult to discern what was even being photographed, much less any defining characteristics that might, for example, help distinguish the leaves of Echinochloa crusgalli from those of Paspalum distichum. The other major reason web images were used is because it was desirable to have pictures of species at various stages of their life cycles and acquiring such photographs independently would have required an addition season in the field.

Photographs and drawings were collected from a wide variety of sources, but a few websites were particularly helpful due to the large sizes of their collections and/or the quality of their photography. CalPhotos, located at http://elib.cs.berkeley.edu/, and www.calflora.org fit both of these descriptions, and though less geographically pertinent,

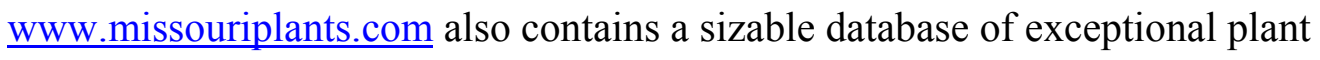
photography. Another frequently used site was the University of California Integrated Pest Management website at http://www.ipm.ucdavis.edu/, which contains photographs 
of common weeds at different growth stages, as well as useful text descriptions for field identification.

While the images contained in this guide already reside in the public domain, this unique compilation provides a valuable resource for researchers or plant enthusiasts interested in the wetlands of Grasslands Ecological Area. Care was taken to produce a guide that is accurate, user friendly and acknowledges all the sources that allowed for its creation. That said, a lot of detailed information is contained within its pages and mistakes may have been made. Using it in conjunction with other field guides or reference materials will help to ensure accurate results. 


\section{CONTENTS}

Allenrolfea occidentalis Ammannia coccinea

Atriplex spp.

Azolla filicoides

Bidens spp.

Bromus diandrus

Bromus hordeaceus

Bromus tectorum

Centaurea solstitialis

Chamomilla suaveolens

Chenopodium album

Conium maculatum

Cotula coronopifolia

Cressa truxillensis

Crypsis schoenoides

Cynodon dactylon

Cyperus esculentus

Distichlis spicata

Downingia spp.

Echinochloa crusgalli

Echinodorus berteroi

Eleocharis spp.

Frankenia salina

Grindelia squarrosa

Hordeum jubatum

Hordeum murinum

Juncus balticus

Juncus bufonius

Lactuca serriola

Lasthenia spp.

Leptochloa fascicularis

Leymus triticoides

Lotus corniculatus

Malva spp.

Melilotus officinalis

Paspalum distichum

Phragmites australis

Polygonum lapathifolium

Polygonum punctatum

Polypogon monspeliensis

Portulaca oleracea

Psilocarphus spp.

Rumex spp.

Sagittaria calycina

Salicornia spp.

Scirpus maritimus

Scirpus spp.

Sorghum halepense

Spergularia spp.

Sporobolus airoides

Typha spp.

Xanthium strumarium

Illustrations

Plant terms

References
Iodinebush 2

Redstems 3

Saltbush 4

Waterfern 5

Beggar-ticks 6

Ripgut brome $\quad 7$

Soft brome $\quad 8$

Cheatgrass 9

Yellow starthistle 10

Pineapple weed 11

Lambsquarters 12

Poison hemlock 13

Brass buttons 14

Alkali weed 15

Swamp timothy 16

Bermuda grass $\quad 17$

Chufa 18

Saltgrass 19

Calicoflower 20

Watergrass 21

Burhead 22

Spikerush 23

Alkali heath $\quad 24$

Curlycup gumweed 25

Foxtail barley 26

Hare barley $\quad 27$

Baltic rush 28

Toad rush 29

Prickly lettuce $\quad 30$

Goldfields 31

Sprangletop 32

Creeping wildrye 33

Trefoil 34

Mallow 35

Yellow sweetclover $\quad 36$

Jointgrass 37

Common reed 38

Pale smartweed 39

Dotted smartweed 40

Rabbitsfoot grass $\quad 41$

Common purslane $\quad 42$

Woolly marbles 43

Dock 44

Hooded arrowhead 45

Pickleweed 46

Alkali bulrush $\quad 47$

Bulrush 48

Johnson grass $\quad 49$

Sandspurry 50

Alkali sacaton $\quad 51$

Cattail 52

Cocklebur 53

54

56

59 
Allenrolfea occidentalis (Iodinebush)

- Native perennial shrub

- Usually from between $30 \mathrm{~cm}$ and $1 \mathrm{~m}$ tall

- Low, straggly, woody shrub that has round, succulent, gray-green, jointed stems that ascend from a woody root

Stems

- Much-branched, jointed

- Green to glaucous, fleshy

Leaves

- Sessile, more or less decurrent

- Alternate, reduced and scale-like

Inflorescence

- Inconspicuous flowers are produced on short scaly spikes

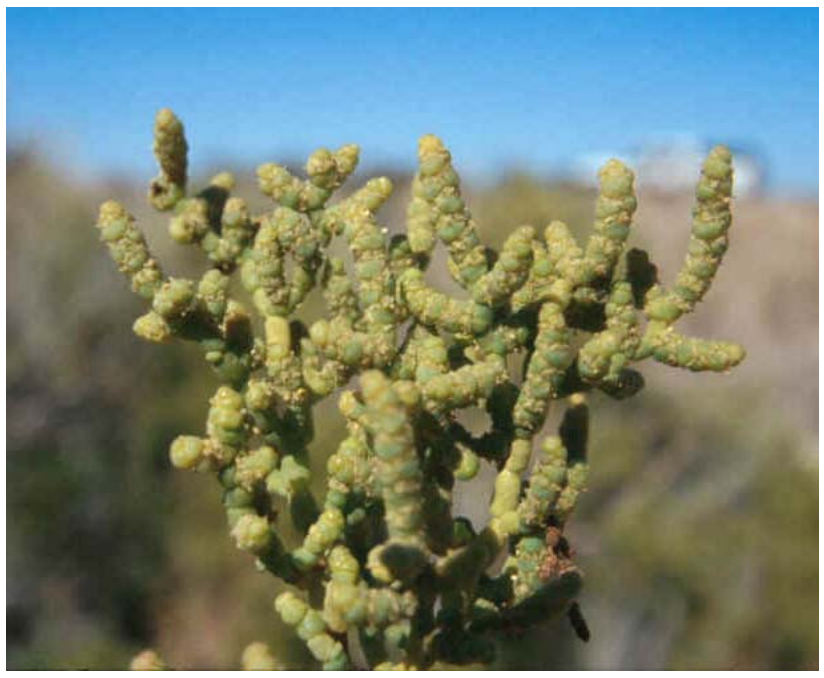

The Vascular Plant Herbarium Arizona State University

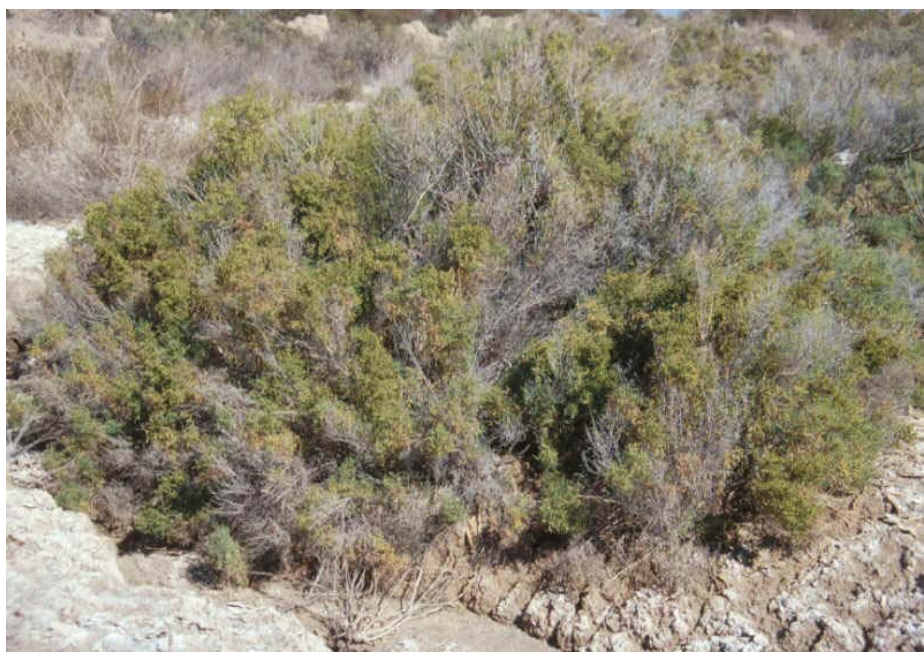

The Vascular Plant Herbarium

Arizona State University

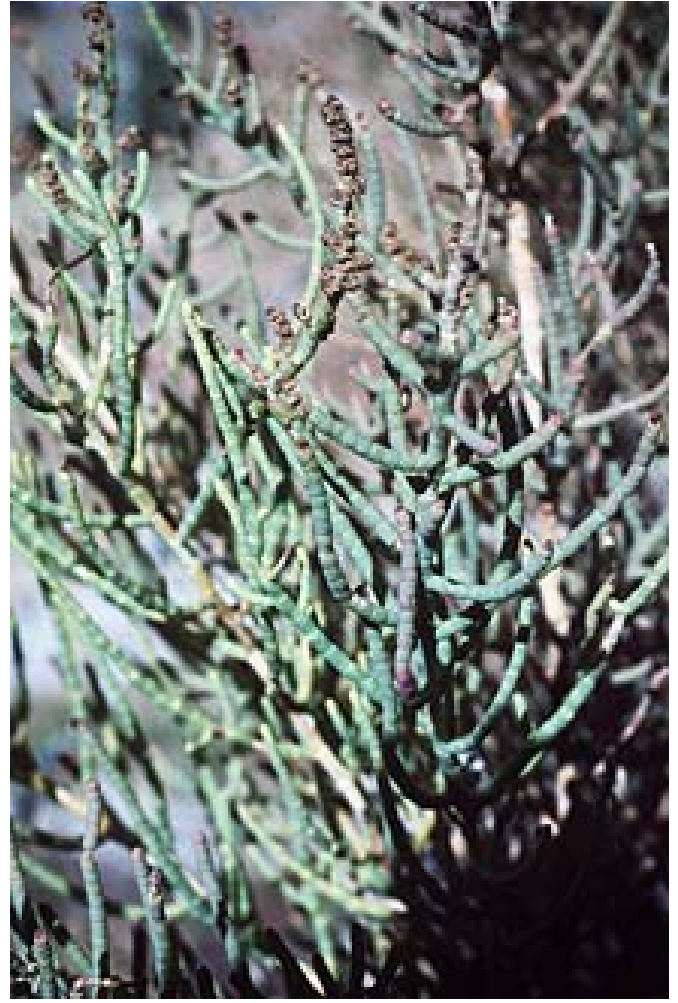

(C) W.L. Wagner

USDA-NRCS PLANTS Database

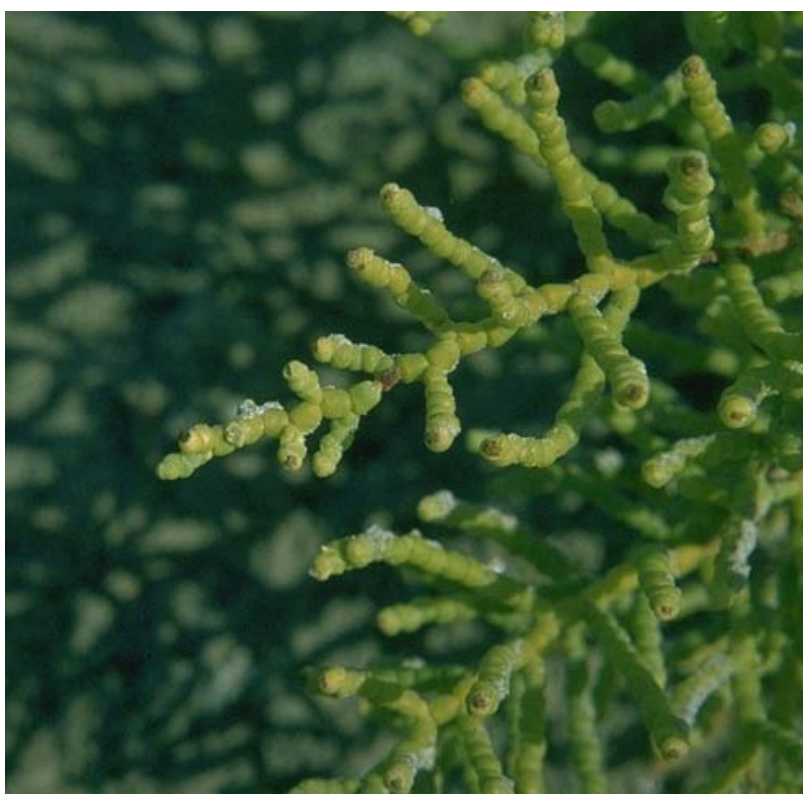

(C) Saint Mary's College of California Br. Alfred Brousseau, photographer 


\section{Ammannia coccinea (Redstems)}

- Native, annual

- Low salinity tolerance

Stems

- 4-angled, decumbent to erect

- $1-10 \mathrm{dm}$ tall

- Single stemmed or extensively branched Leaves

- Opposite, 4-ranked, sessile, linear to oblanceolate

- 2-8 cm long, 2-15 $\mathrm{mm}$ wide

- Auricled at the base, stalkless Inflorescence (May to October)

- Flowers appear in the leaf axils in groups of 3-4

- Very small, approximately 3-4 $\mathrm{mm}$ across

- Hypanthium is urn-shaped

- 4 sepals, 4 deep rose-purple petals

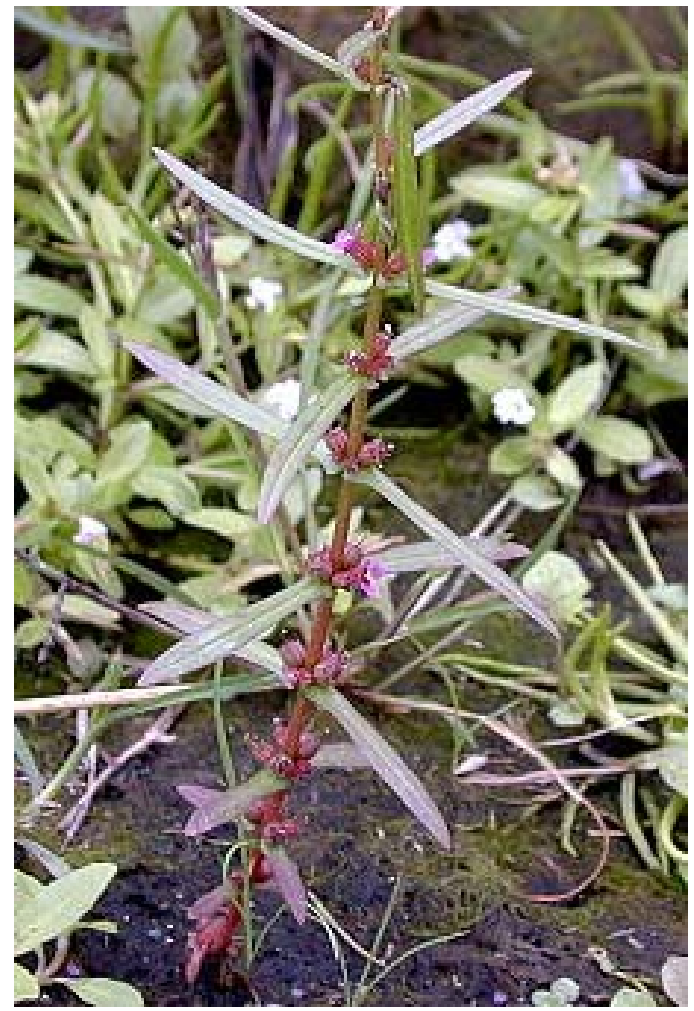

Copyright info unknown

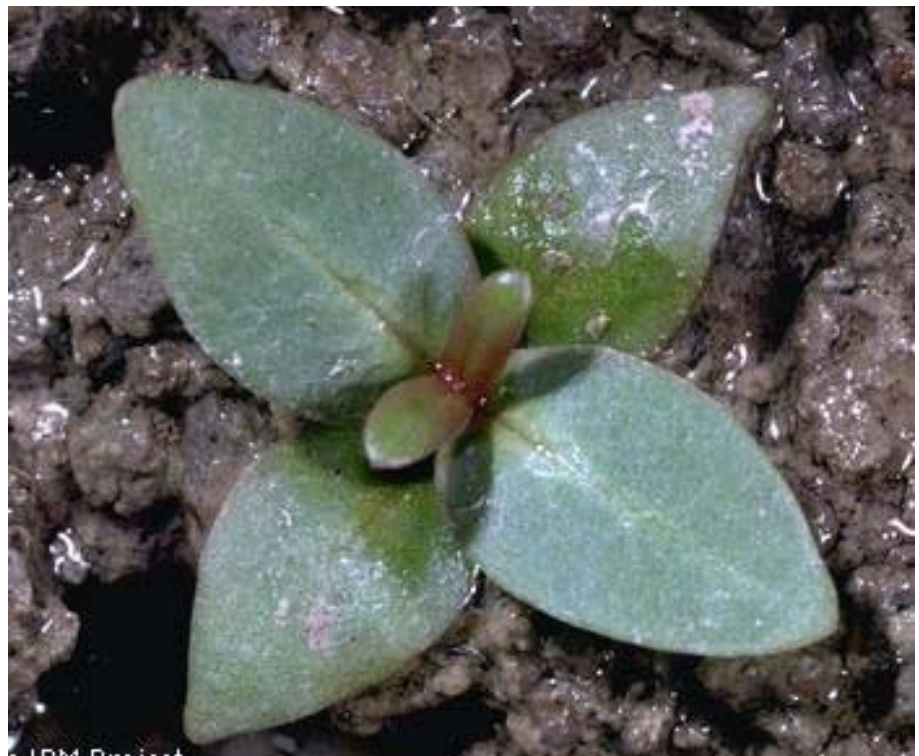

(C) 2000 Regents, University of California UC Statewide IPM Program Jack Kelly Clark, photographer

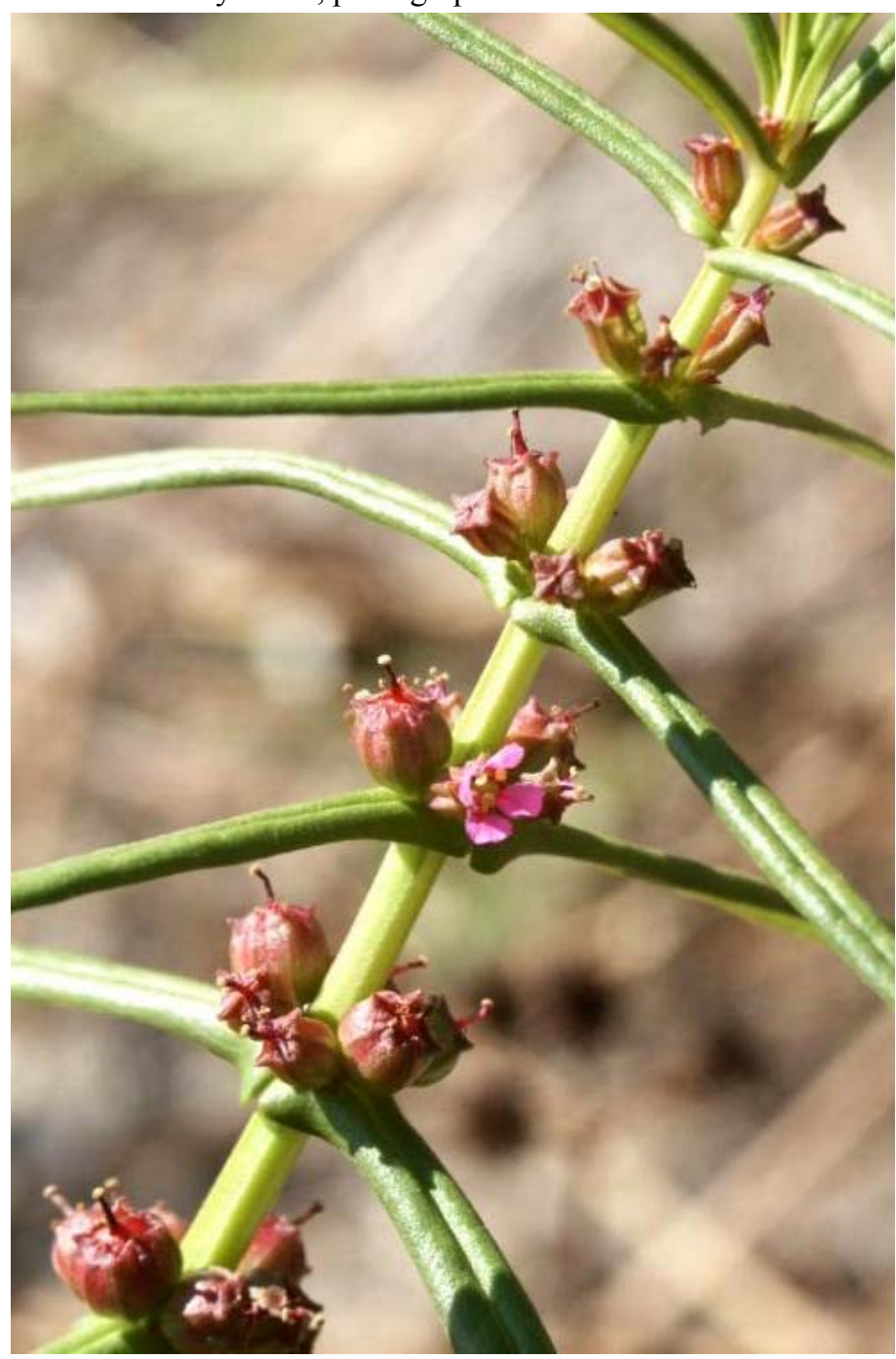

(C) 2003 Michael Charters 
Atriplex spp.

- Many species, highly varied

- Often in alkaline or saline soils (some accumulate selenium)

Stems

- Decumbent to erect

- Often scaly

Leaves

- Generally alternate and without teeth

- Lower with short petioles, upper leaves generally sessile and reduced

Inflorescence

- Separate male and female structures on same plant (monoecious)

- Usually spikes or spheric clusters

- No bracts on male, 2 bracts on female

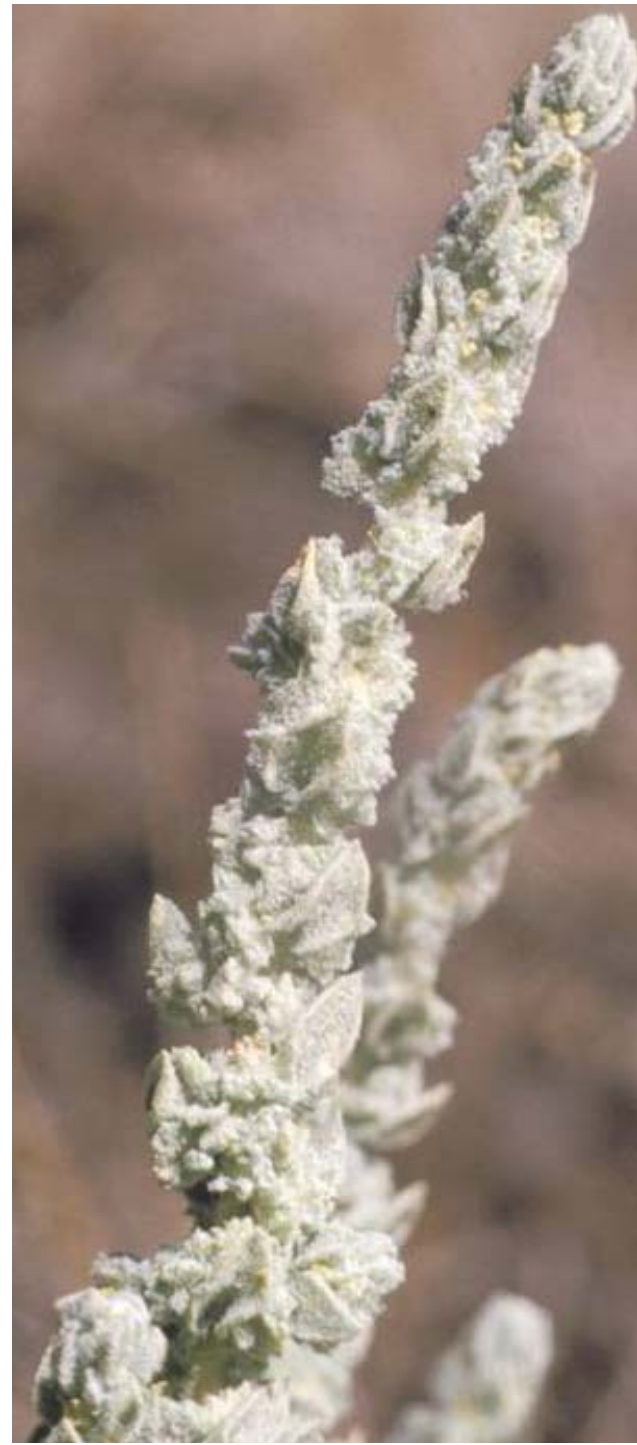

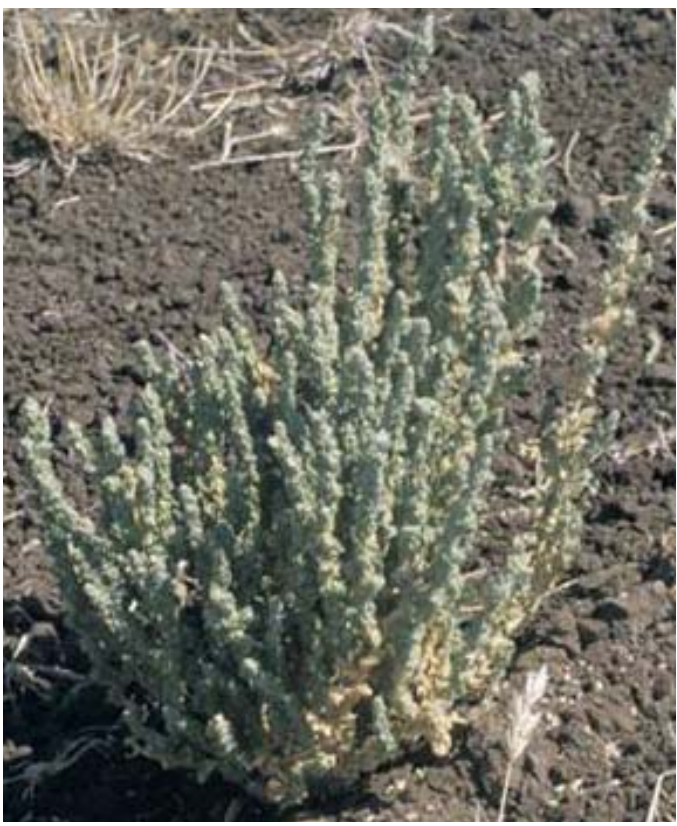

Atriplex coronata

(C) 1994 Robert E. Preston, Ph.D.

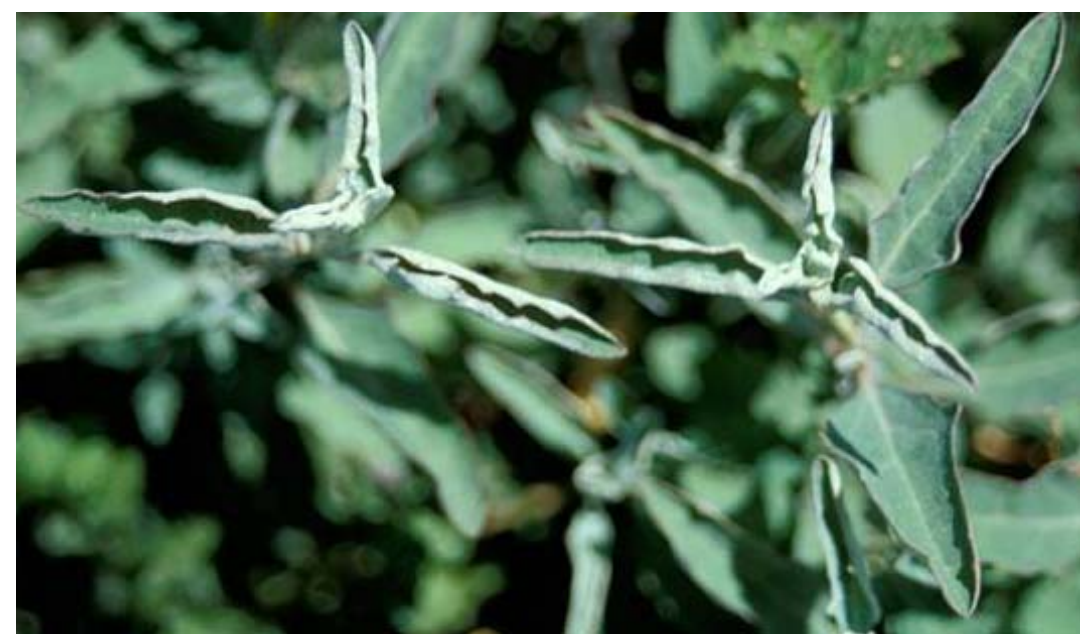

Atriplex semibaccata

(C) John M. Randall, The Nature Conservancy

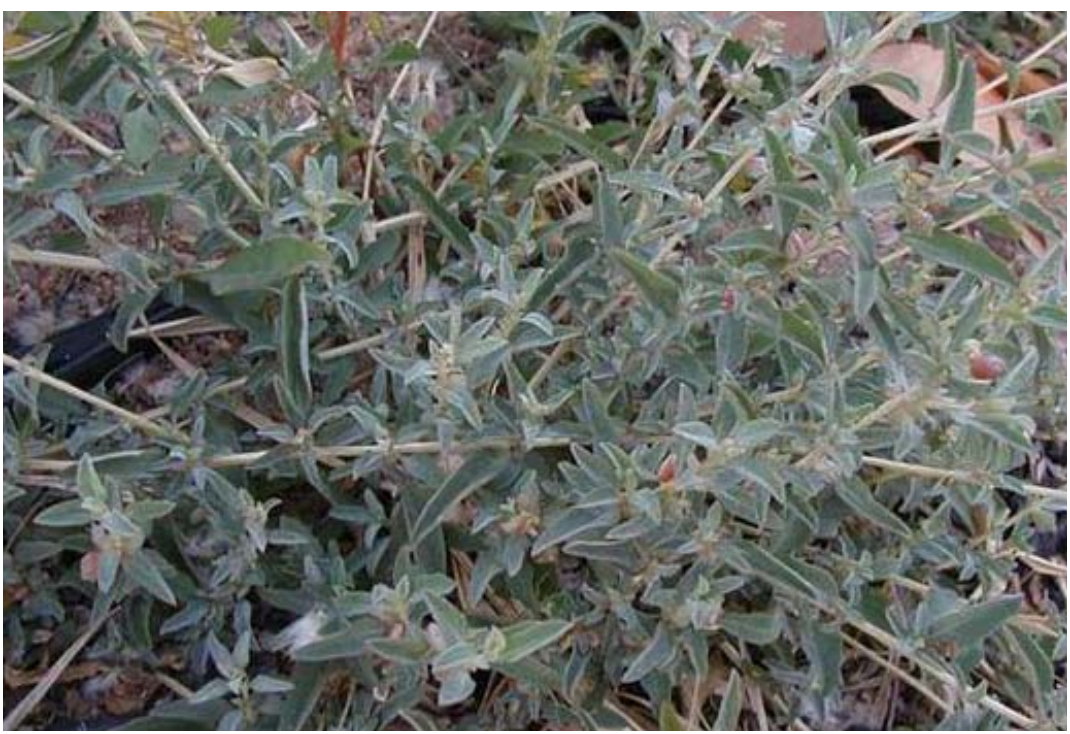

Atriplex semibaccata

(C) 2004 Debra Valov

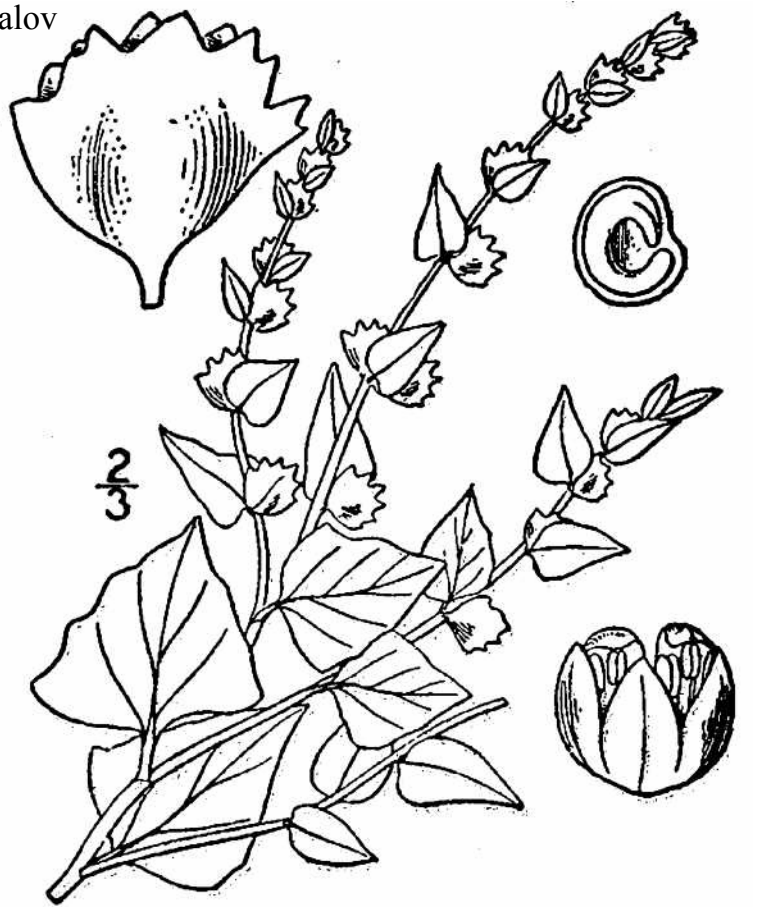

Atriplex argentea

1913 Britton, N.L. and A. Brown 
Azolla filiculoides (Water fern)

- Free-floating green to reddish plant

- Common in slow streams, ponds, wet ditches (not in saline water)

Stems

- Immature prostrate, mature ascending

- Thread-like, easily fragmented at joints Leaves

- $1 / 2-1 \frac{1}{2} \mathrm{~mm}$

- Alternate, in two rows

- Sessile and often overlapped

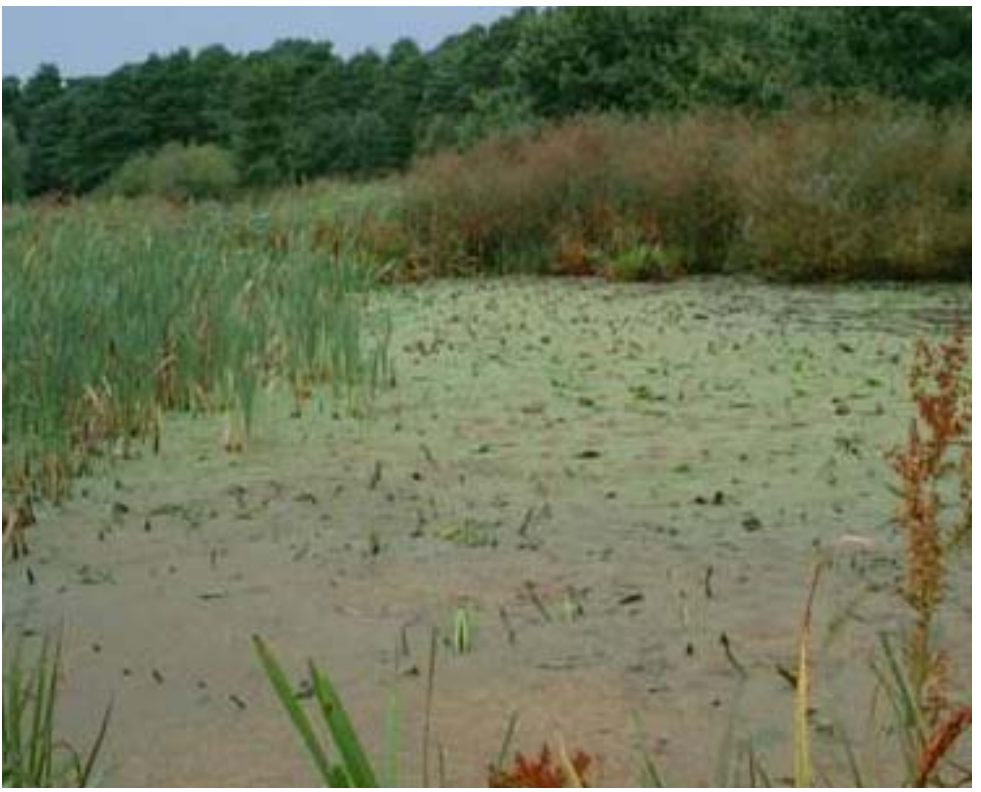

(C) 2001 Dr. Arved Lompe

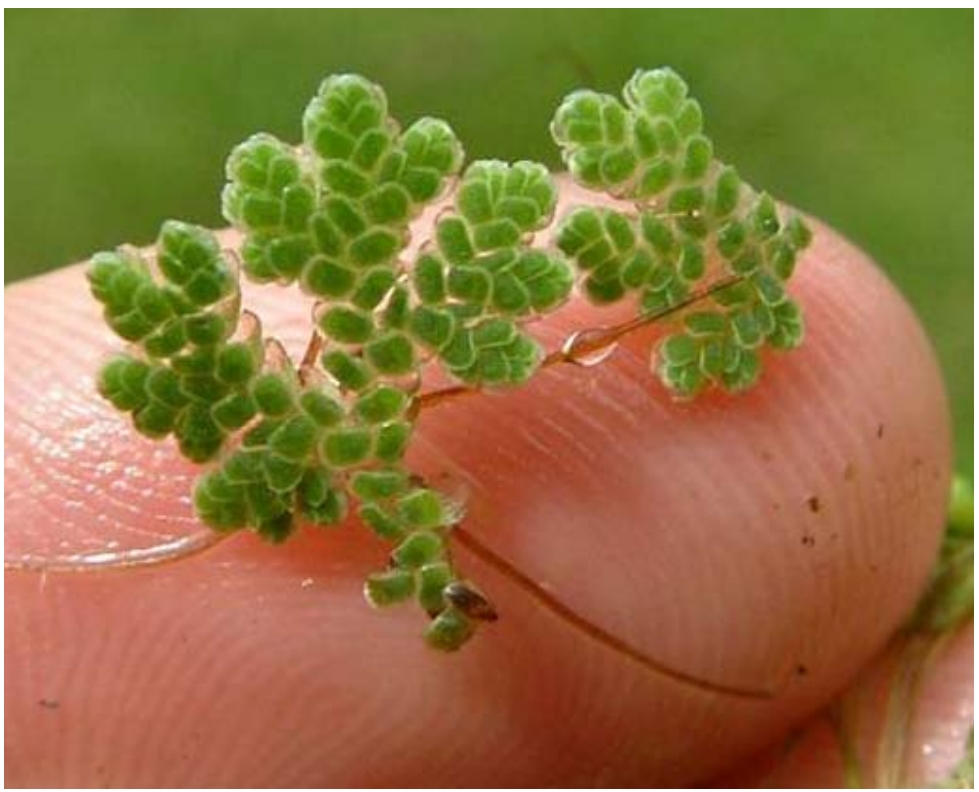

(C) Ian Dodkins

University of Ulster

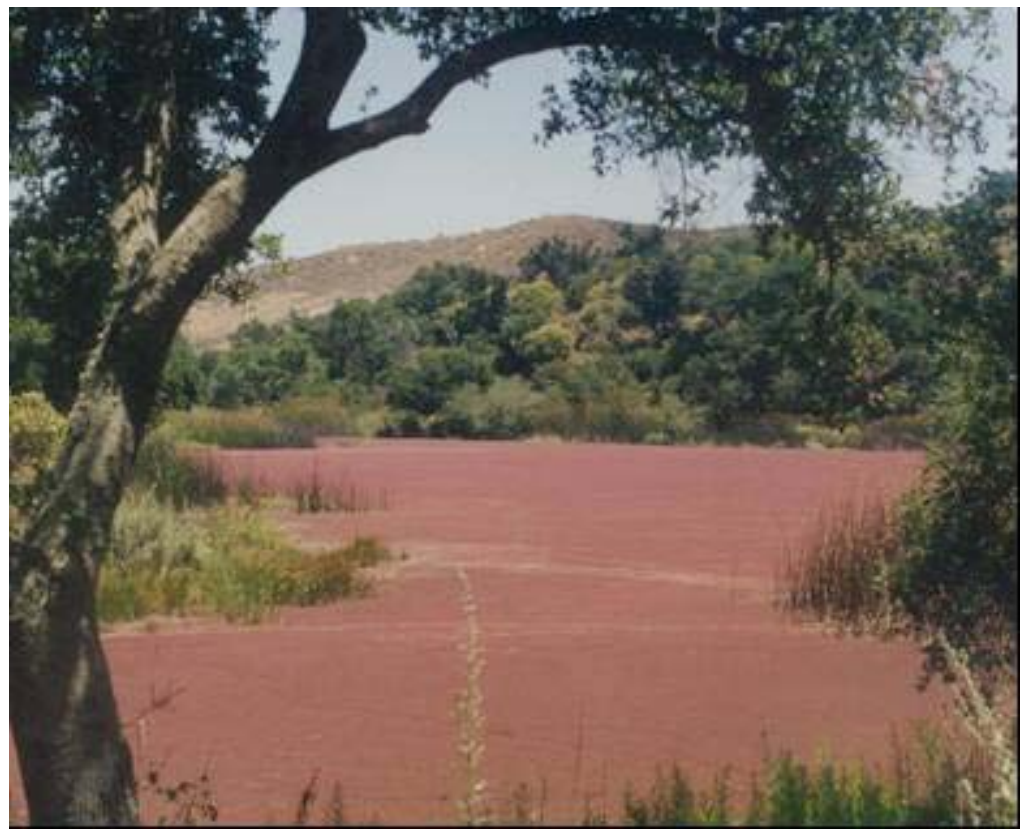

(C) 2000-2003 Barbara J. and Lorence G. Collins

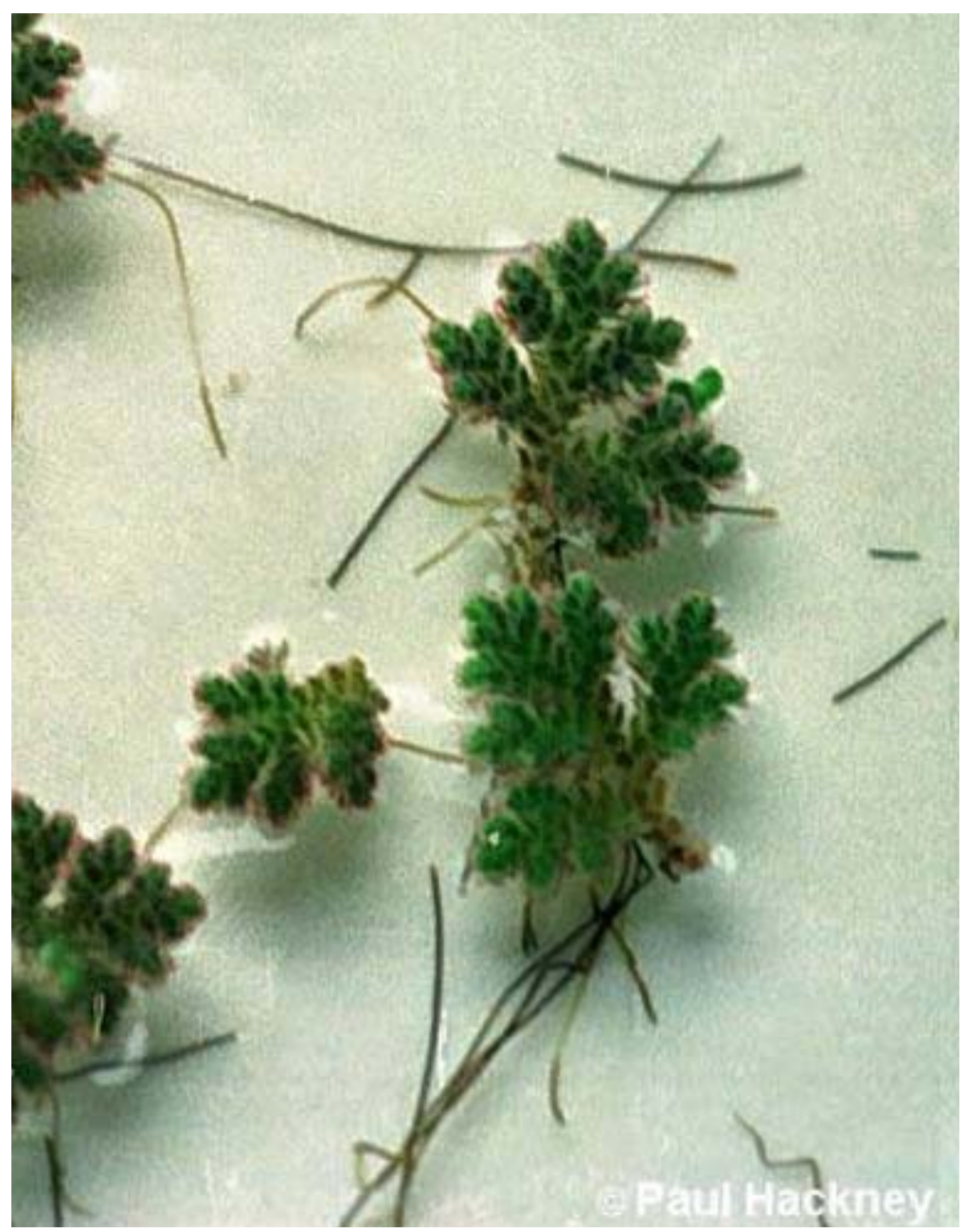

(C) Paul Hackney

Ulster Museum Botanical Gardens 


\section{Bidens spp. (Beggar-ticks)}

- Annual, native

Stems

- $\quad 5-12 \mathrm{dm}$ tall

- Erect and square (rounded angles)

- Smooth

Leaves

- $\quad$ 2-8 $\mathrm{cm}$ long, up to $4 \mathrm{~cm}$ wide

- Opposite, pinnate, serrate and petioled

- Generally long and tapered with sharp tip

- With teeth that generally point tipward

- Leaflets puberulent and light green above, pubescent and dull green below

Inflorescence (August-October)

- Ray flowers not present or few

- Each flower subtended by pinnately divided leaf segments and 5-8 leafy bracts

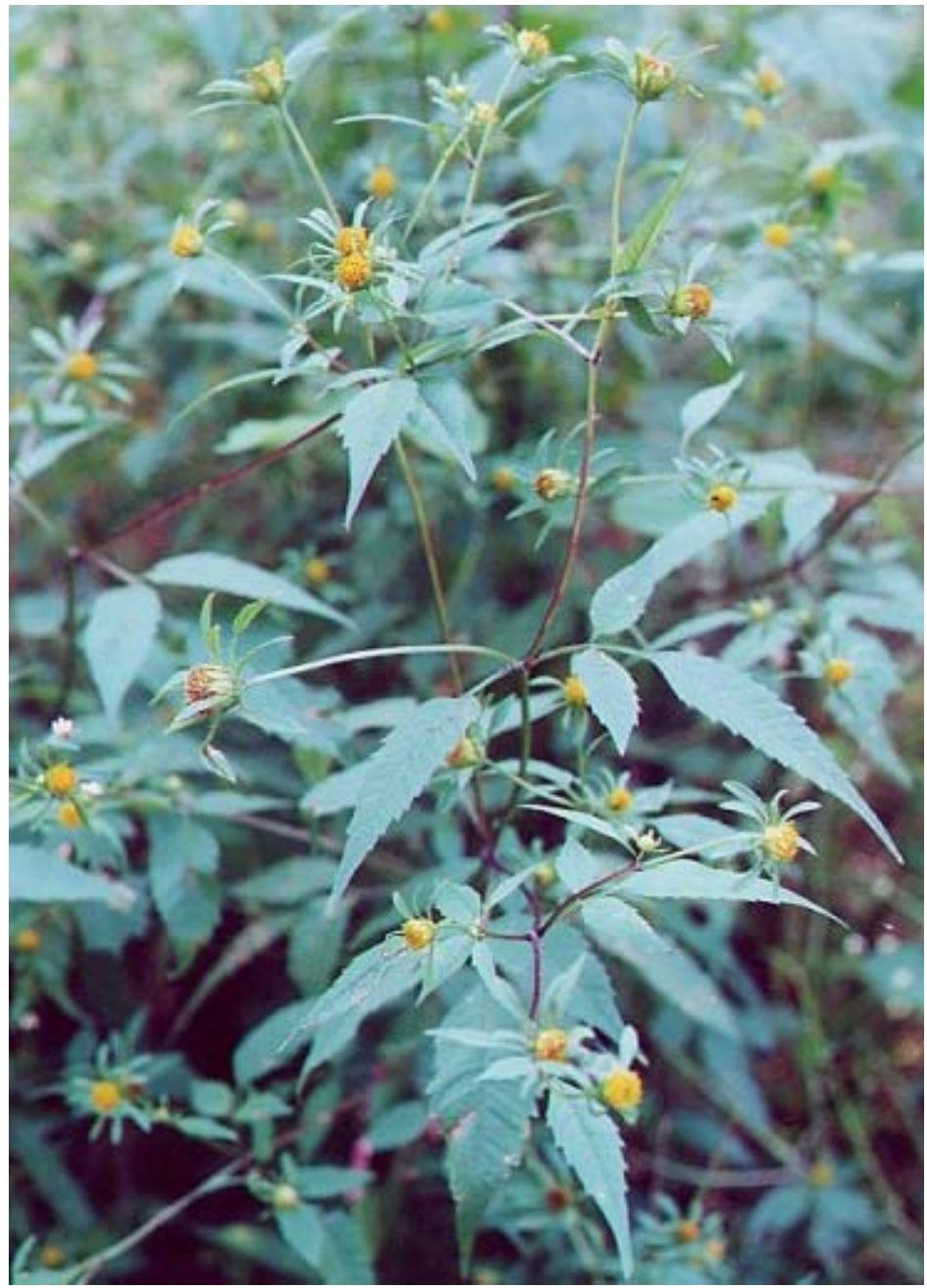

Dan Tenaglia, www.missouriplants.com

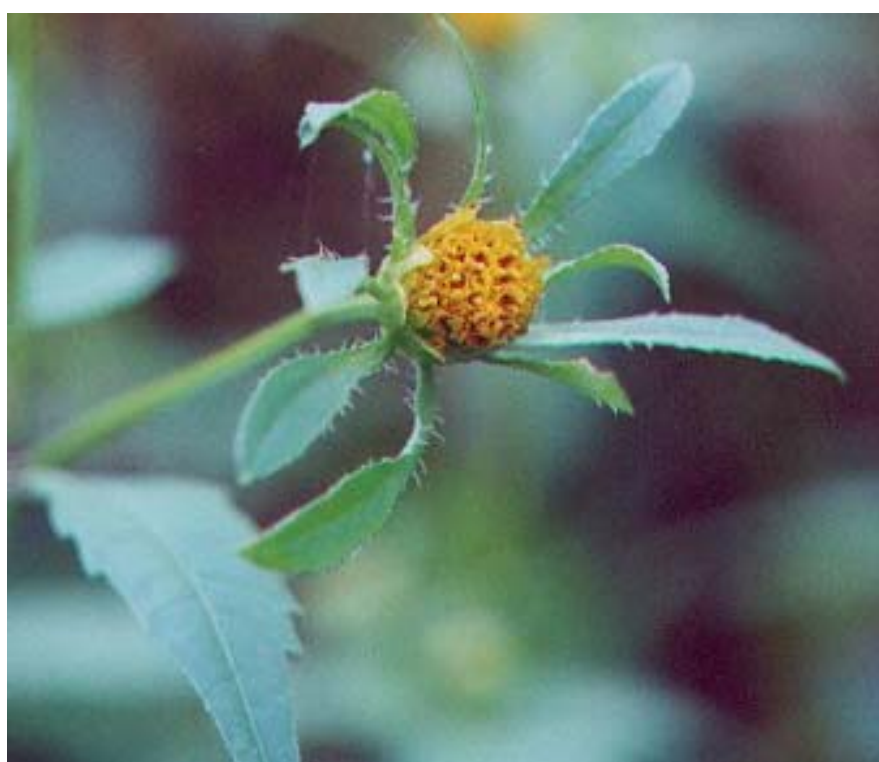

Dan Tenaglia, www.missouriplants.com

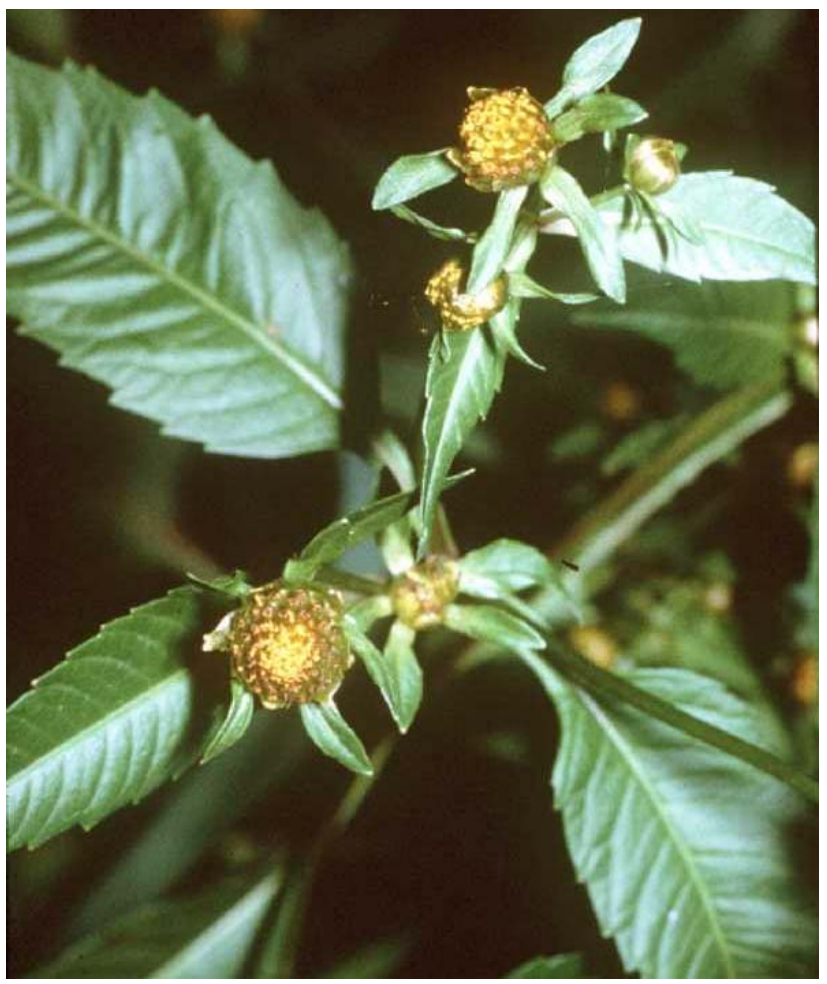

1989 Robert H. Mohlenbrock USDA-NRCS PLANTS Database 
Bromus diandrus (Ripgut brome)

- Not native, annual

Leaves

- Tubular sheath on the seedling, distinguishing it from most other grass seedlings

- Soft hairs cover the blades and sheaths

- The membranous ligule is long, whitish, and jagged, no auricles present

Inflorescence

- Open panicles resemble oats

- Large spikelets have awns that are $21 / 2-5 \mathrm{~cm}$ long, distinguishing it from soft brome, which has much shorter awns

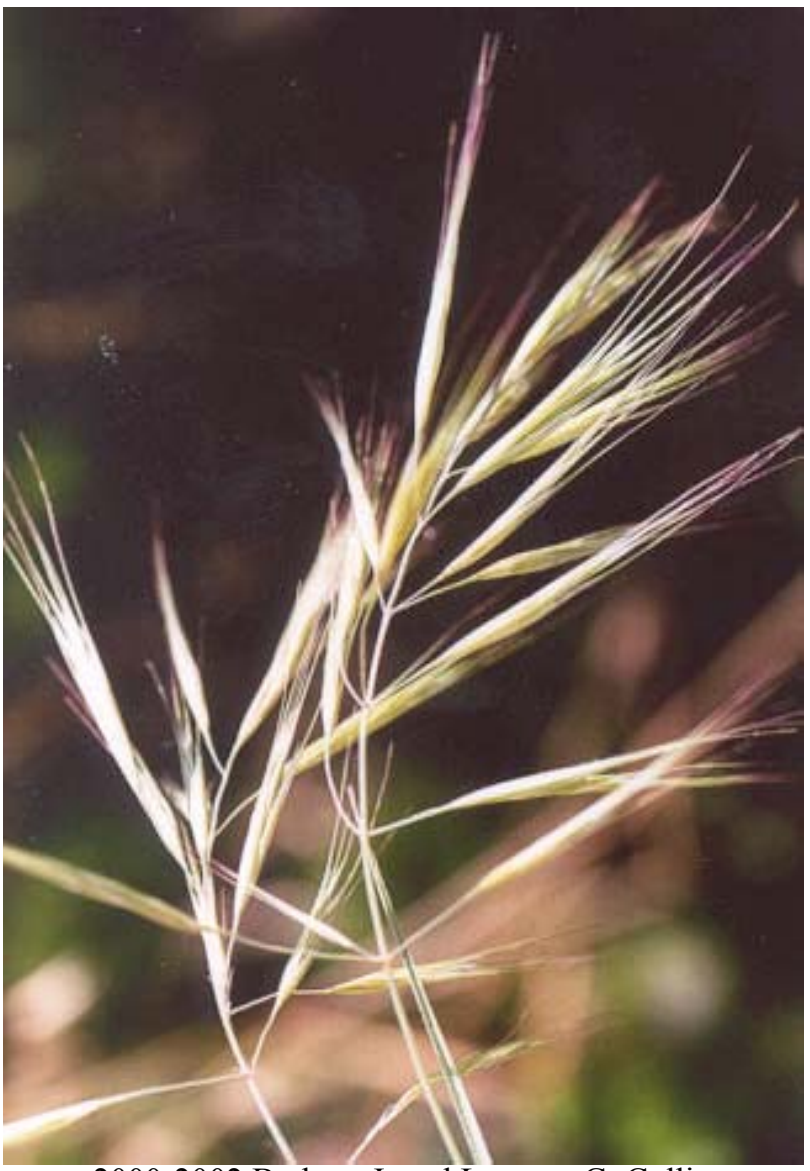

2000-2002 Barbara J. and Lorence G. Collins

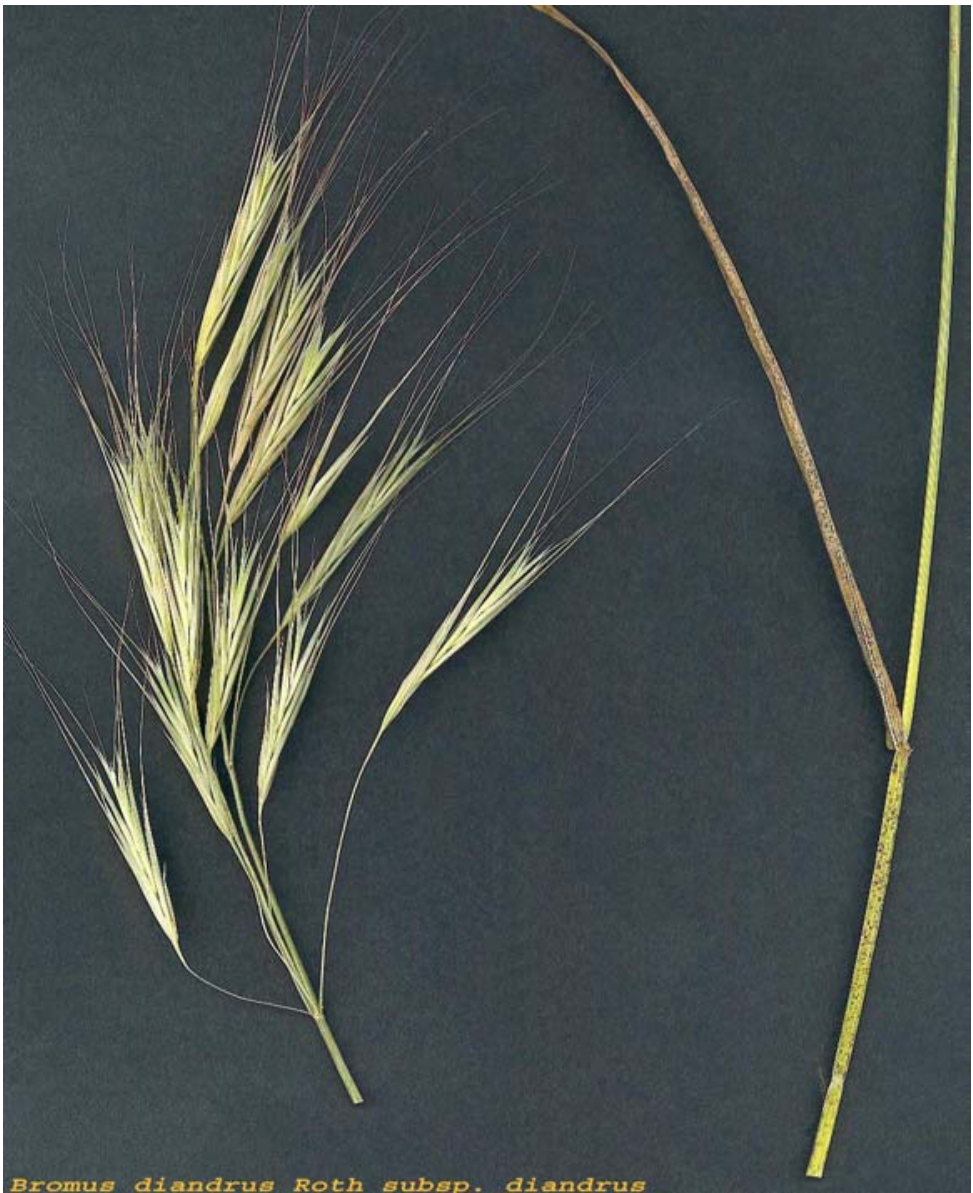

University of Illes Balears (Spain), Dept of Biology

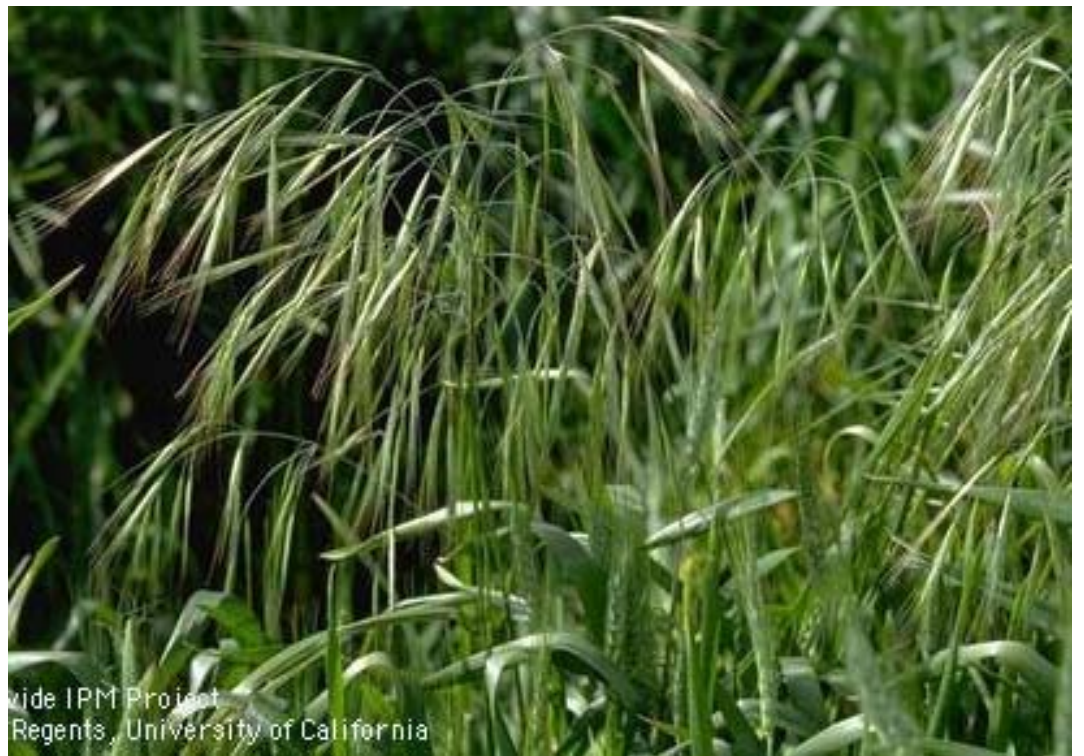

2000 Regents, University of California UC Statewide IPM Program Jack Kelly Clark, photographer 
Bromus hordeaceus (Soft brome)

- Non-native, annual

- Plants are 1-6 dm tall

Leaves

- Mature plants are distinguished by dense, soft hairs on sheaths

- No auricles present

- Membranous ligules

Inflorescence

- Compact spikelets form dense flowering heads with awns about $1-1 \frac{1}{2} \mathrm{~cm}$ long

- Seed germination starts in fall

- Plants reach maturity in early summer

- Other common brome grasses in California include ripgut brome, which has long awns, and rescuegrass (B. catharticus), which is awnless or has awns no longer than $3 \mathrm{~mm}$

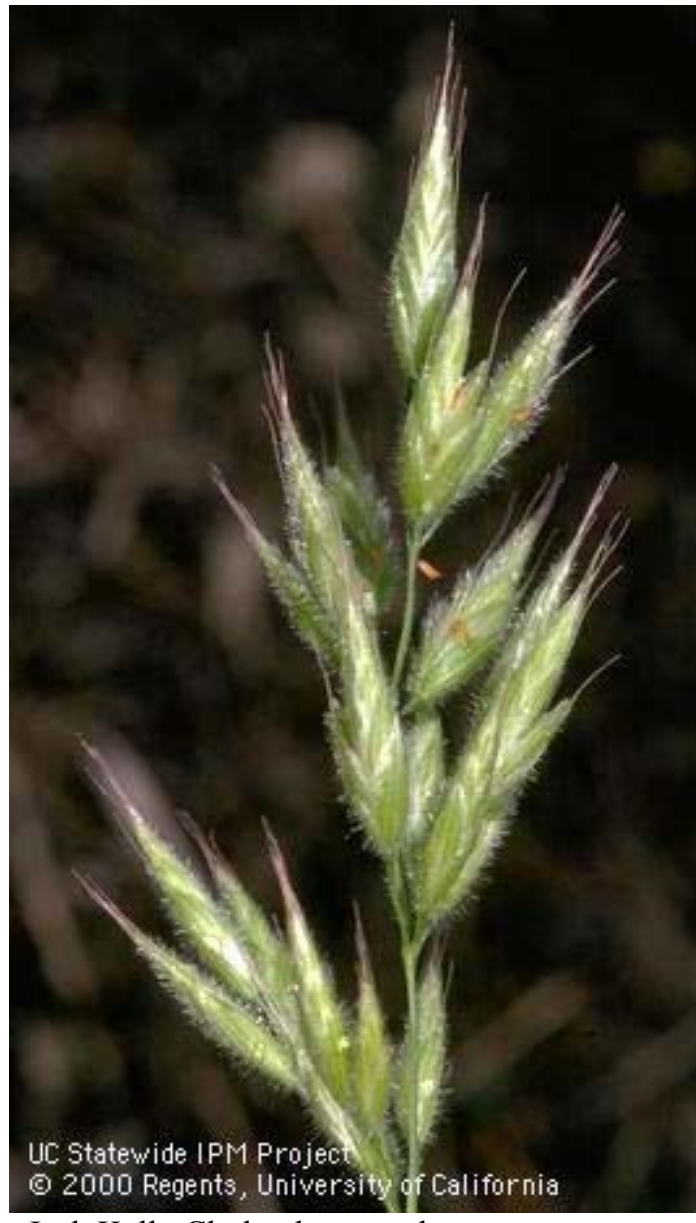

Jack Kelly Clark, photographer

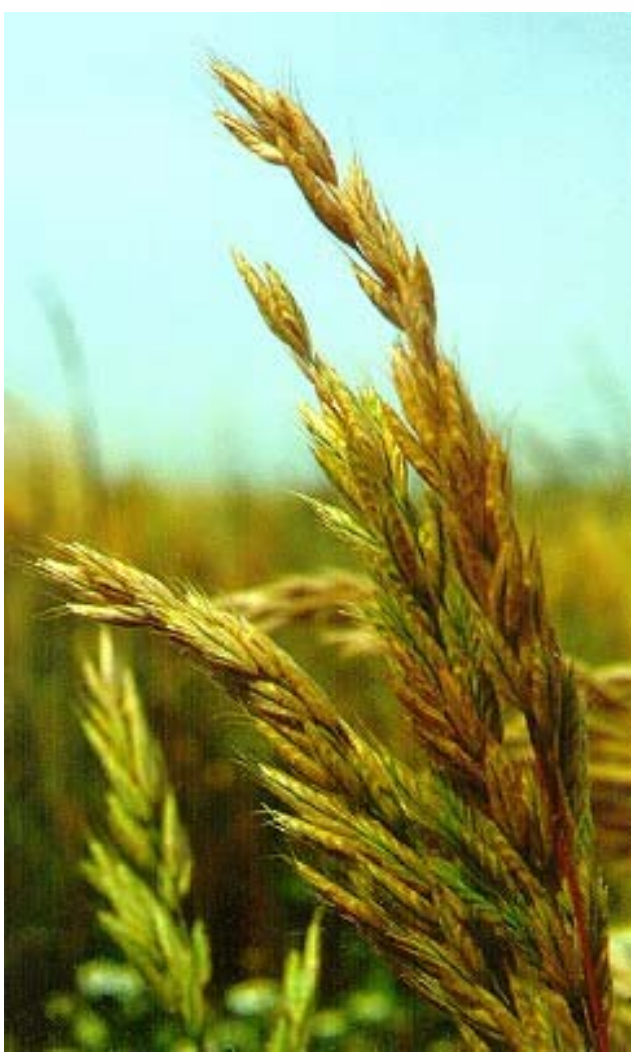

(C) John M. Randall

The Nature Conservancy 


\section{Bromus tectorum (Cheatgrass)}

- Annual, not native

- Seedlings are bright green with conspicuously hairy leaves

- Typically grows 5-6 dm tall

- $\quad$ Species grows quickly in the spring and often matures and sets seeds before most other species

Stems

- Stems are erect, slender, and smooth or may be slightly soft-hairy

- $\quad$ Sheath generally densely soft-hairy

- Blades may be smooth or hairy

- Generally long ciliate near base Inflorescence

- At maturity the foliage and seedheads often become purplish before drying completely and becoming brown or tan

- $\quad$ Nodding, open panicles with moderately awned spikelets are very distinctive

- Panicles are 5-20 cm long, and rather dense

- Branches are slender, with up to 8 spikelets

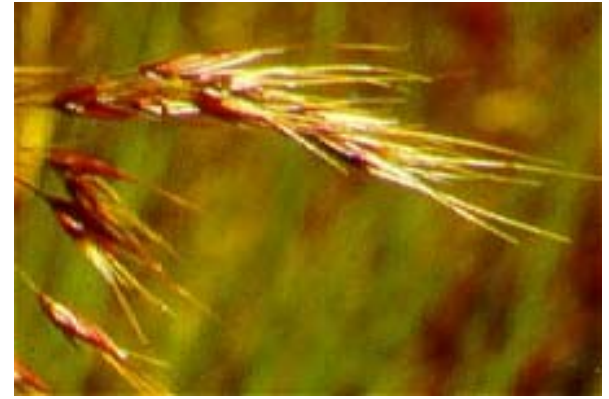

(C) 1995 John M. Randall

The Nature Conservancy

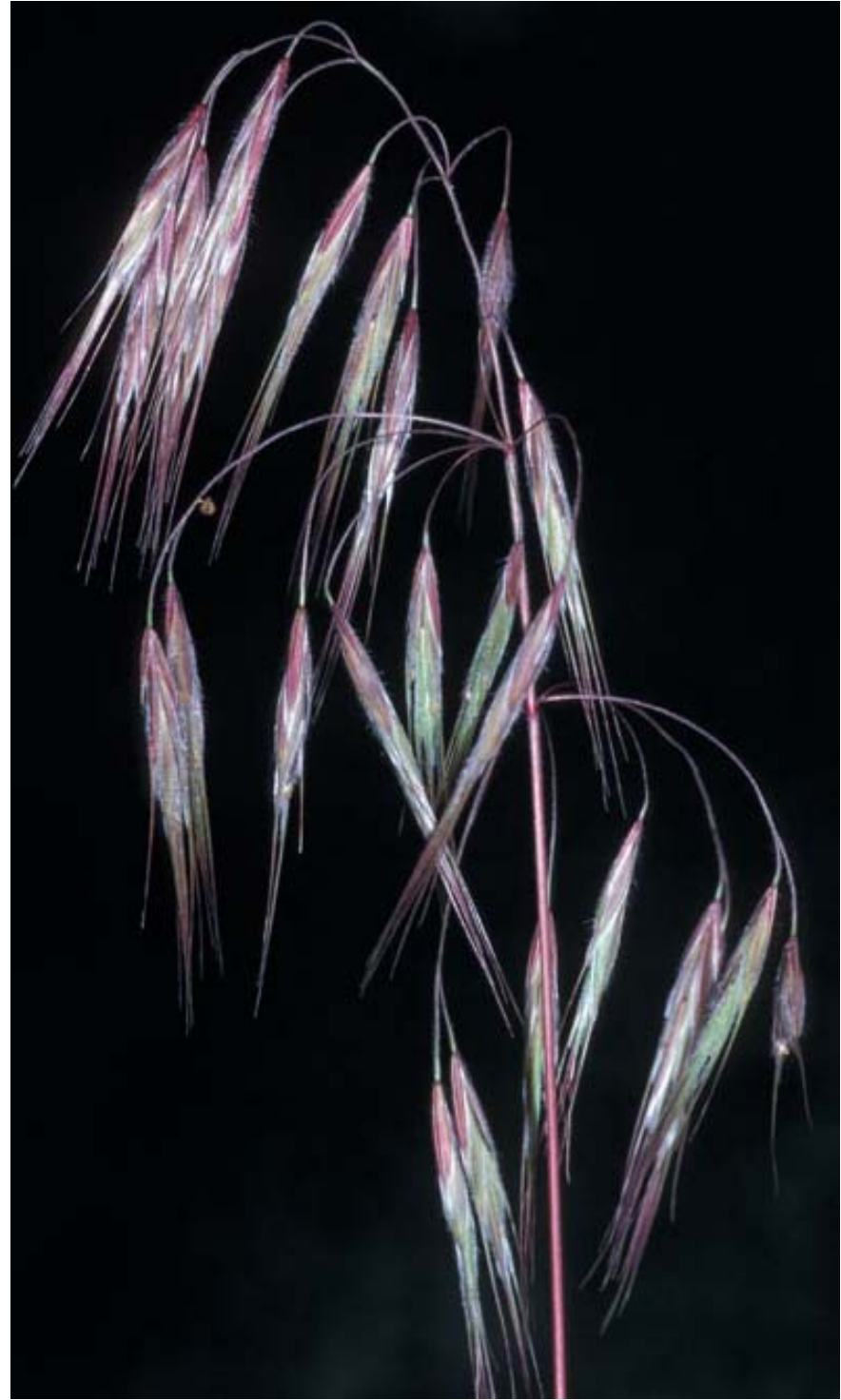

(C) 2001 Joe DiTomaso

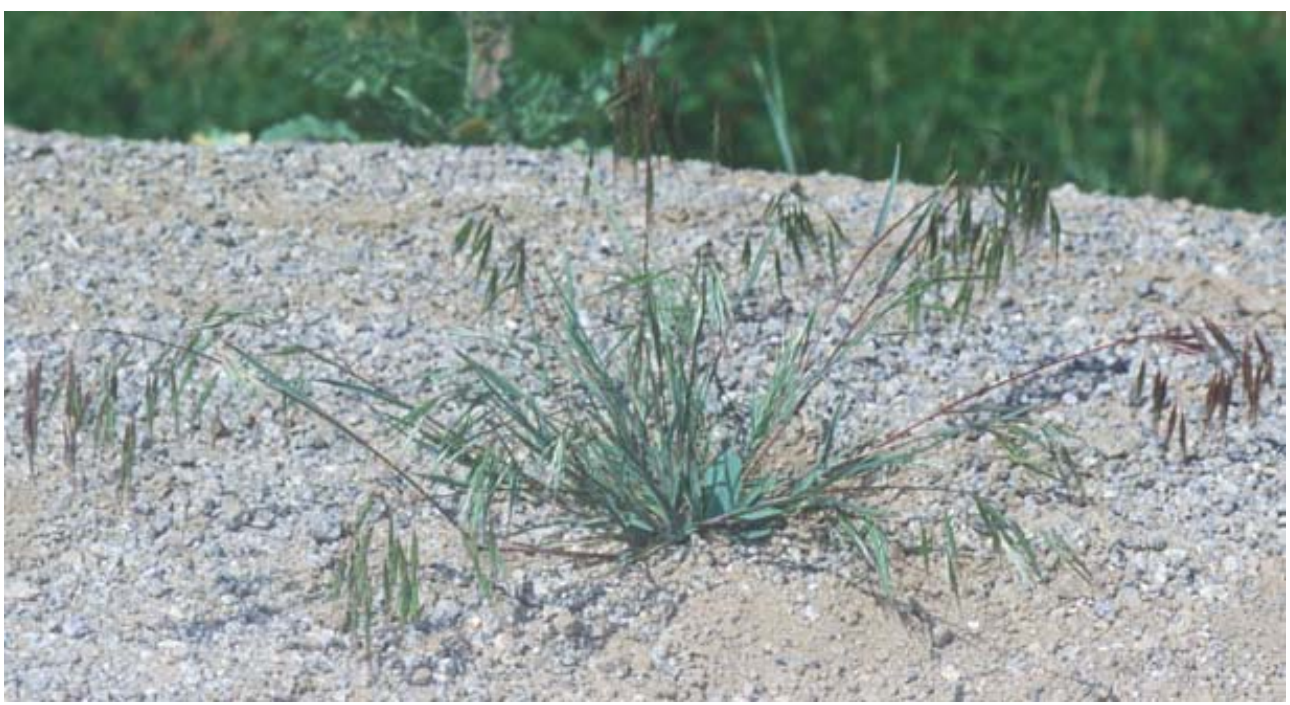

(C) 2001 Joe DiTomaso 
Centaurea solstitialis (Yellow star-thistle)

- Not native, annual

- 1-10 dm, overed with gray, matted hairs Leaves

- Alternate

- Lower are 1-2 lobed and 5-15 cm

- Scabrous-bristly

Inflorescence

- Open, palmately spiny (10-25 mm long)

- Yellow flowers

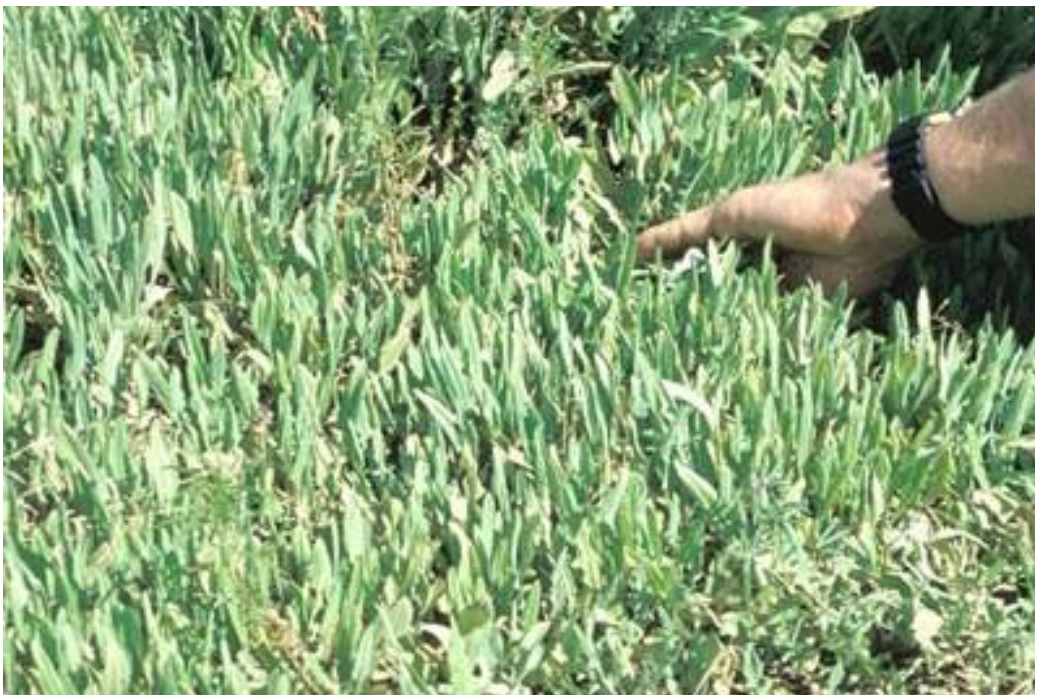

(C) John M. Randall

The Nature Conservancy
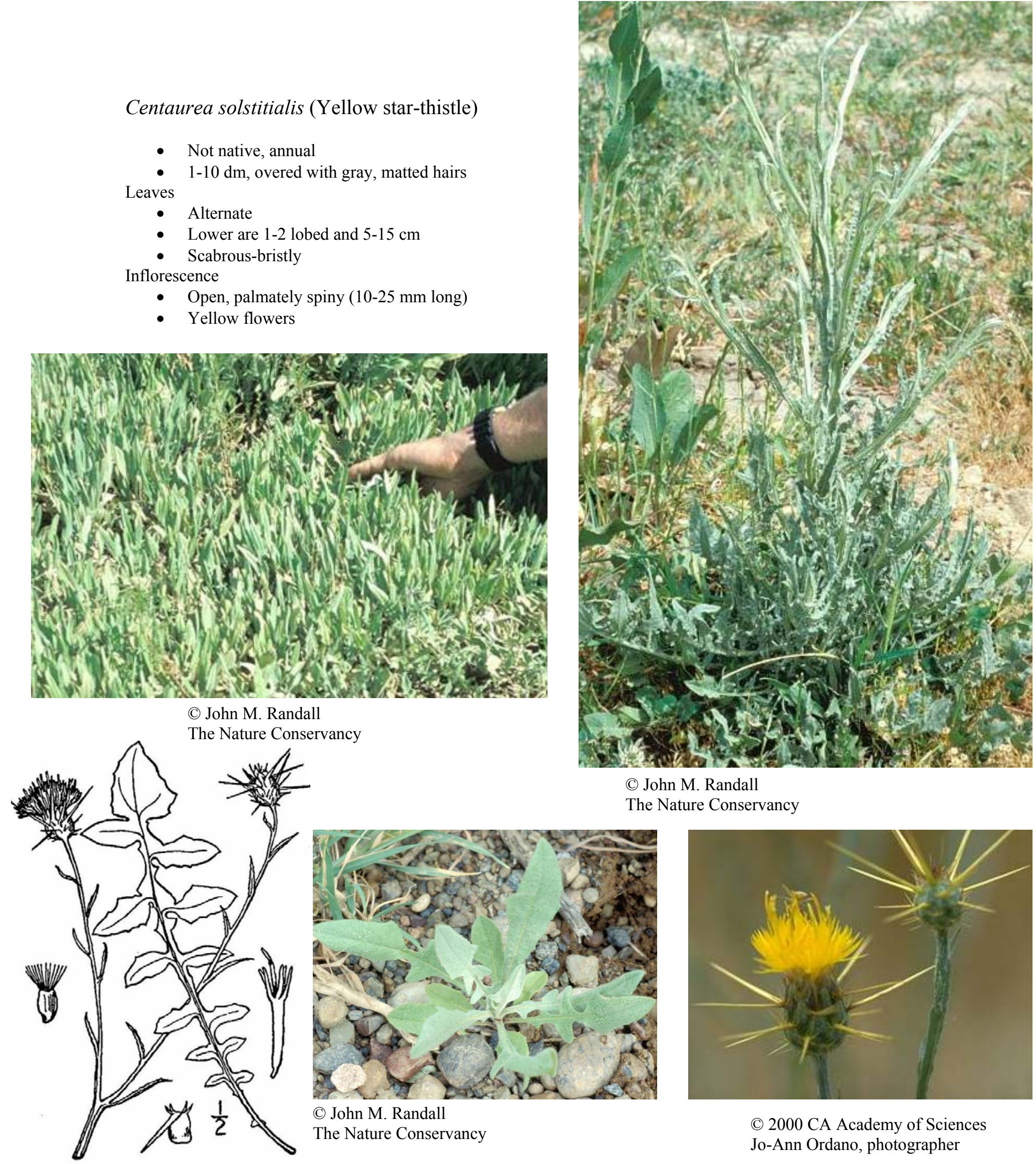

(C) John M. Randall

The Nature Conservancy

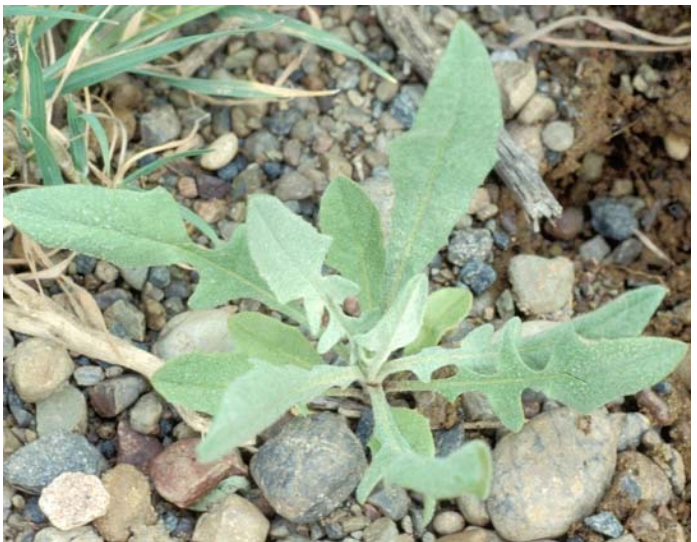

(C) John M. Randall

The Nature Conservancy

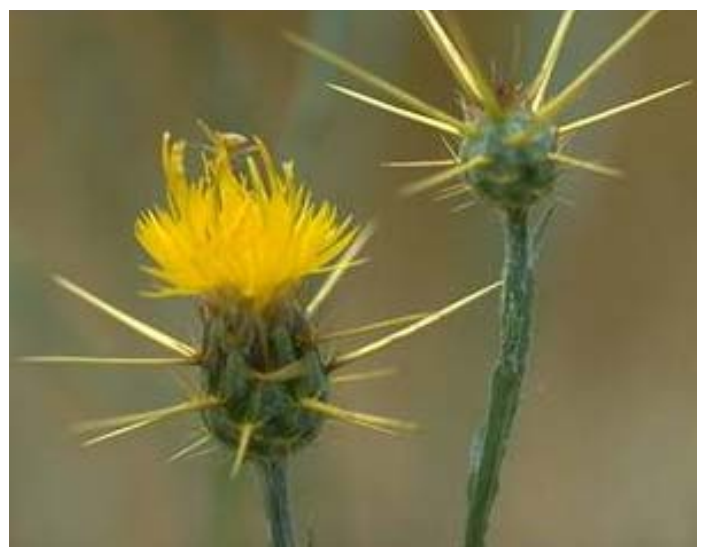

(C) 2000 CA Academy of Sciences Jo-Ann Ordano, photographer

1913 Britton, N.L., and A. Brown USDA-NRCS PLANTS Database 
Chamomilla suaveolens (Pineapple weed)

Stems

- Generally branched from the base

- $71 / 2-30 \mathrm{~cm}$ high

Leaves

- Alternate, irregularly 2-3 pinnately lobed

- Less than $5 \mathrm{~cm}$, hairless and sessile

- Gives a strong, sweet smell when crushed

- Seedlings have bright green, narrow seed leaves that are thick and fleshy

Inflorescence

- $1 \mathrm{~cm}$ diameter, shattering at maturity

- Yellow-green at ends of stems, no showy petals

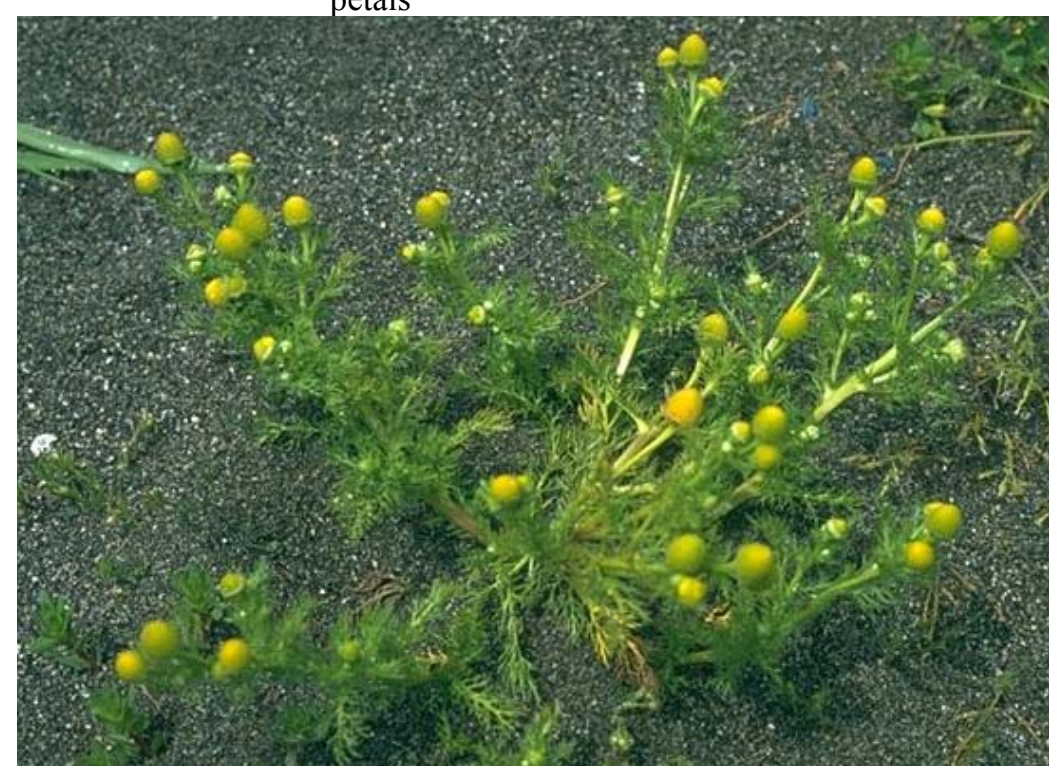

(C) 1995 Saint Mary's College of California

Br. Alfred Brousseau, photographer

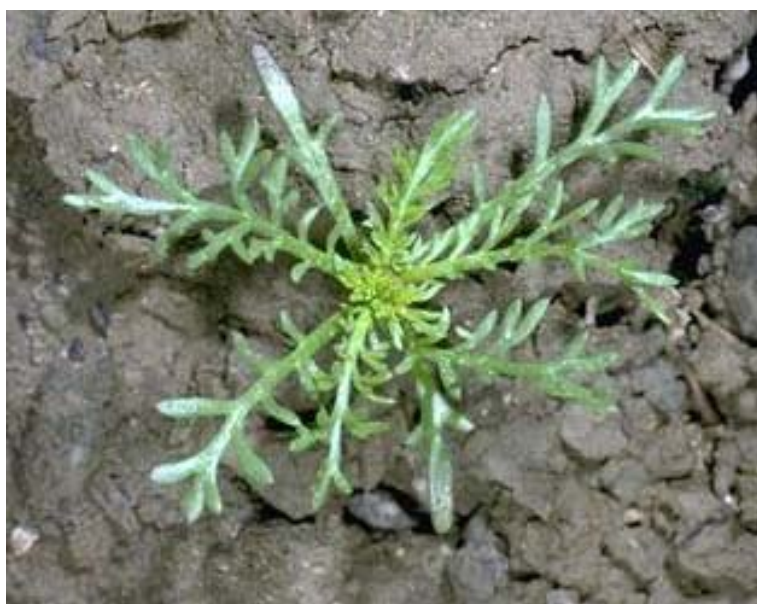

(C) 2000 Regents, University of California UC Statewide IPM Program Jack Kelly Clark, photographer

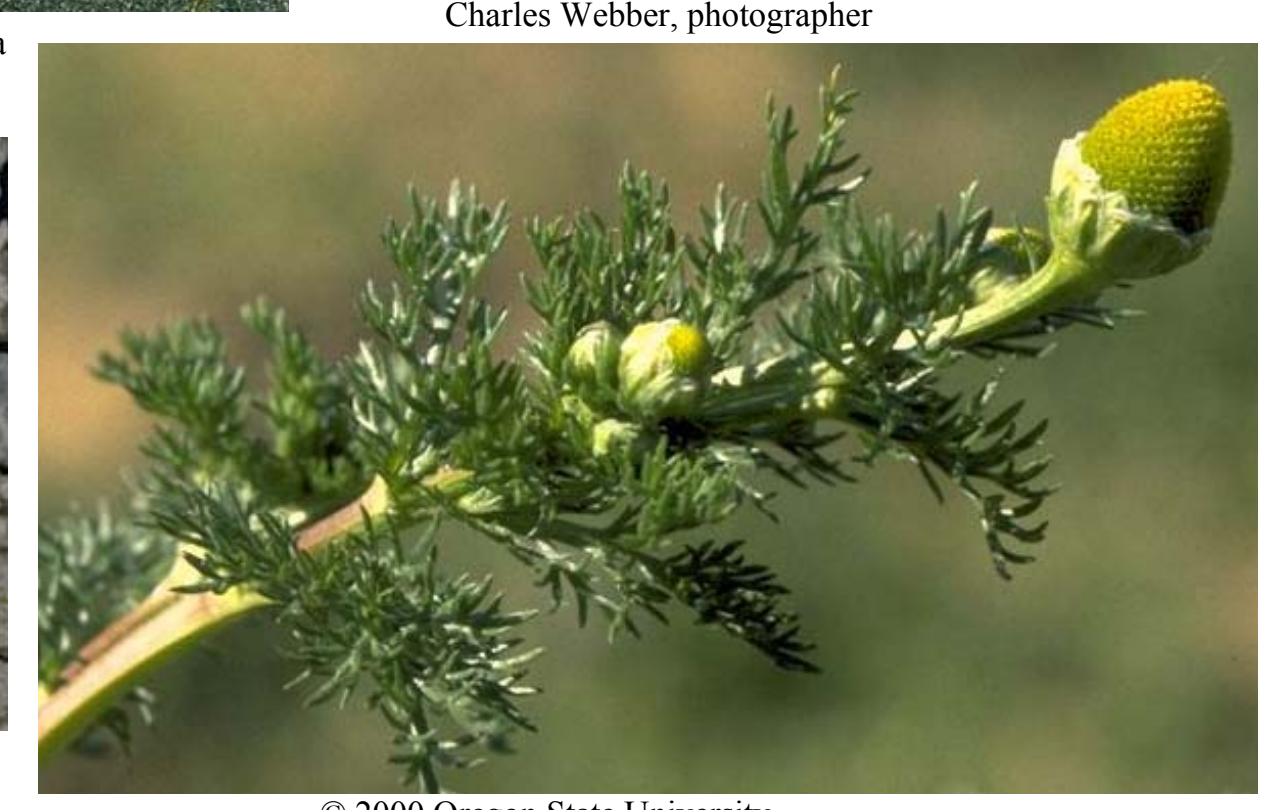

(C) 2000 Oregon State University

(C) 1998 California Academy of Sciences Charles Webber, photographer 
Chenopodium album (Lambsquarters)

$$
\begin{array}{cl}
\text { - } & \text { Annual } \\
\text { - } & 18-100+\mathrm{cm} \text { tall, erect } \\
\text { Leaves } & \\
\text { - } & \text { Blade } 1 \frac{1 / 2-7 \mathrm{~cm}}{} \\
\text { - } & \text { Lanceolate to triangular in shape } \\
\text { - } & \text { Dulire to irregularly wavy-toothed } \\
& \text { Dreen above, powdery below }
\end{array}
$$
Inflorescence

- Flowers small, greenish with white powder

- Compact flower clusters

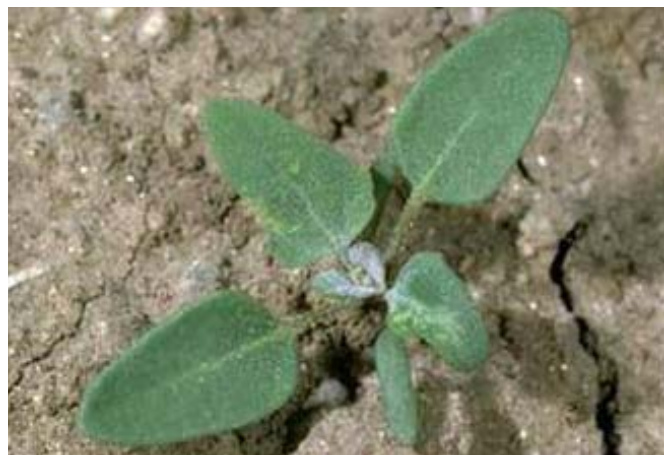

(C) 2003 The Regents of the University of California UC Statewide IPM Program

Jack Kelly Clark, photographer

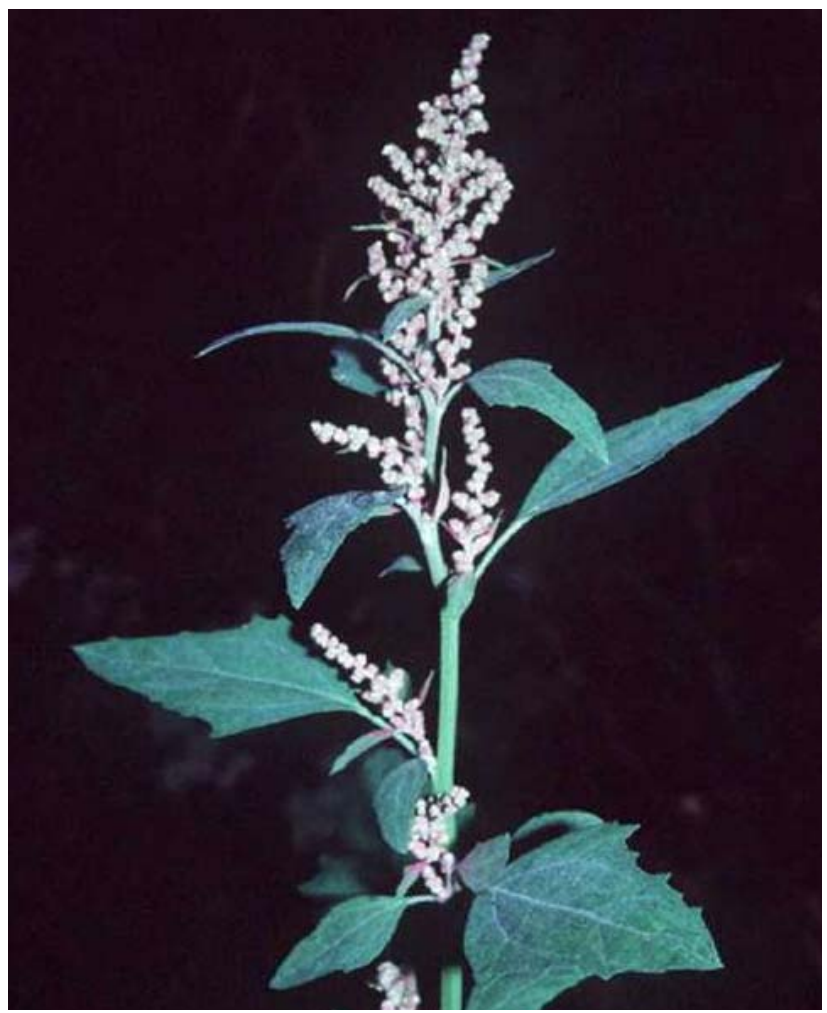

Bill Summers

USDA-NRCS PLANTS Database

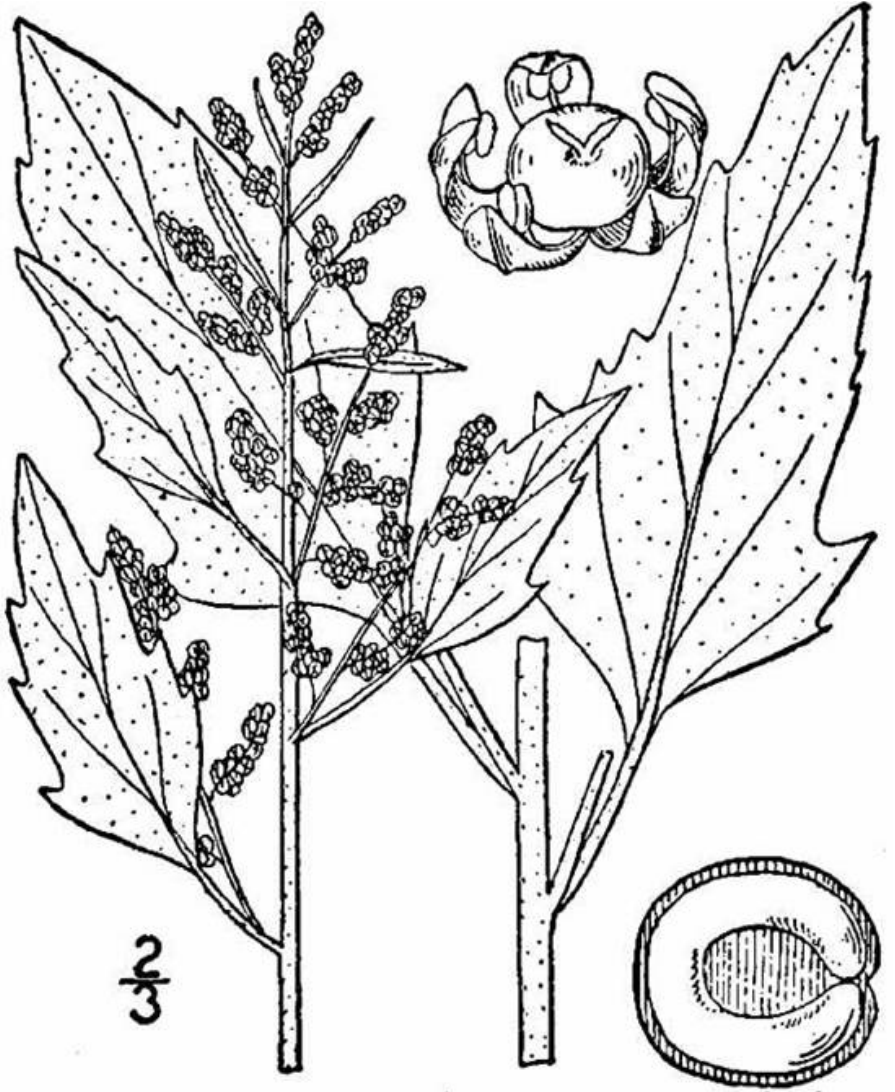

1913 Britton, N.L., and A. Brown USDA-NRCS PLANTS Database

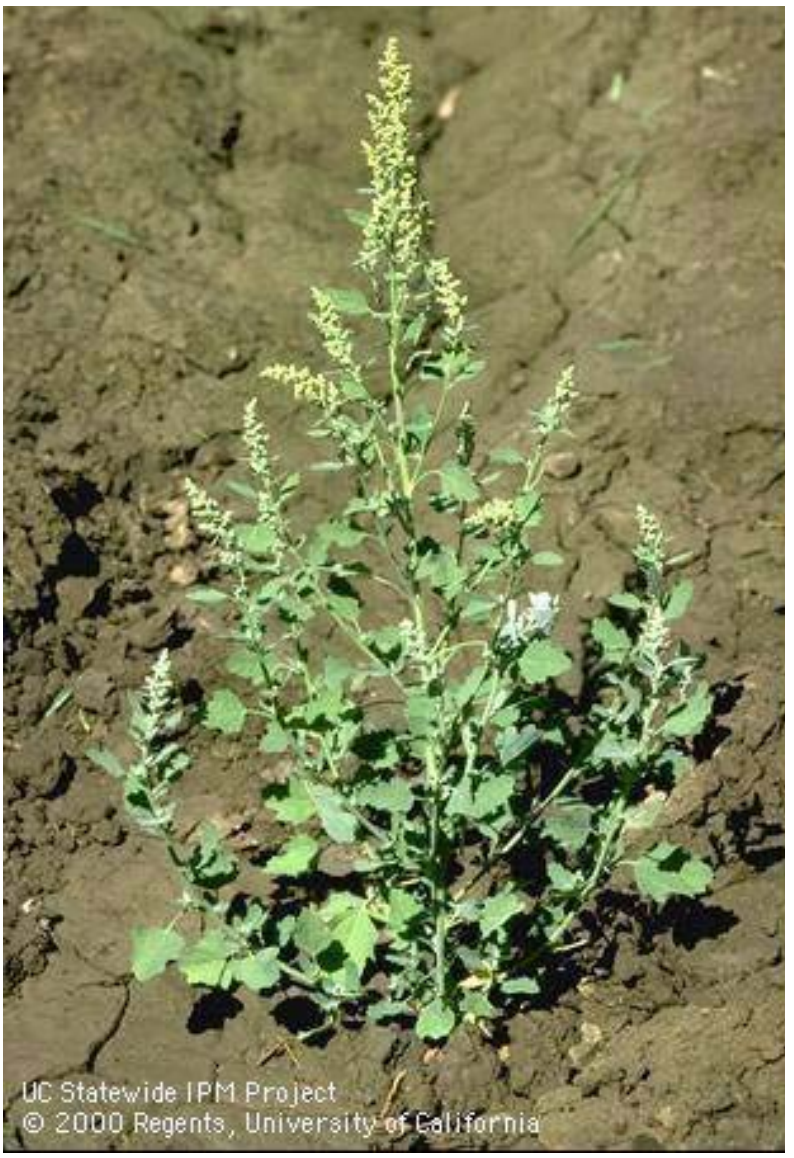

Jack Kelly Clark, photographer 
Conium maculatum (Poison hemlock)

- Biennial

- Musty-scented

Stems

- Erect, branched, hairless

- Generally purple spotted or streaked Leaves

- Blade 11/2-3 dm, widely ovate, leaflets lanceolate or oblong

- Generally 2-pinnately lobed Inflorescence

- Umbels compound, terminal and lateral

- Highly branched, peduncles 2-8 cm

- Flowers white or yellowish

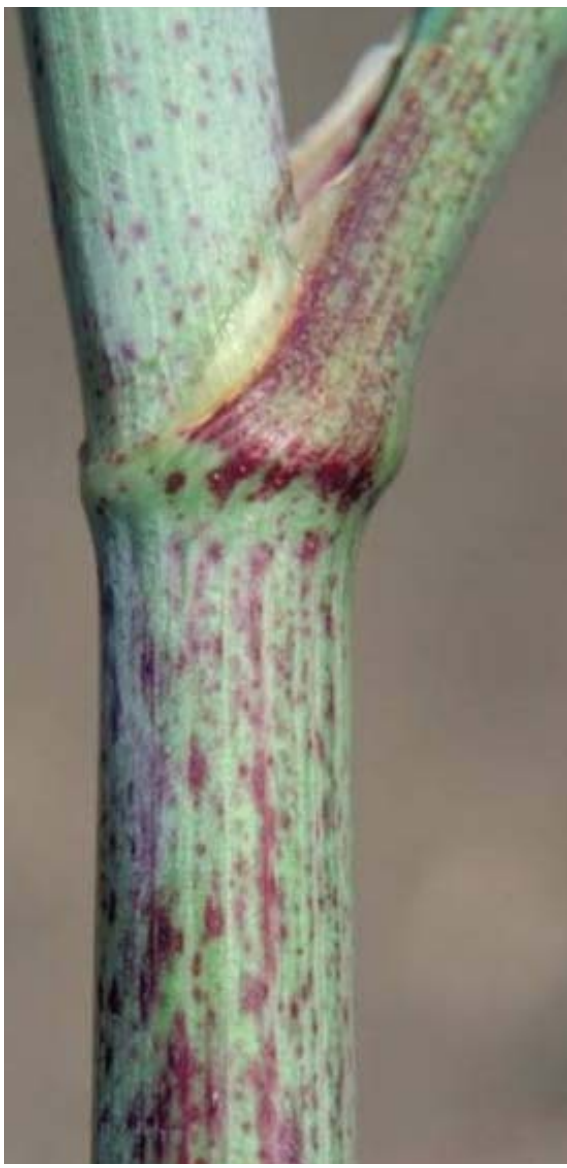

(C) 2001 CDFA

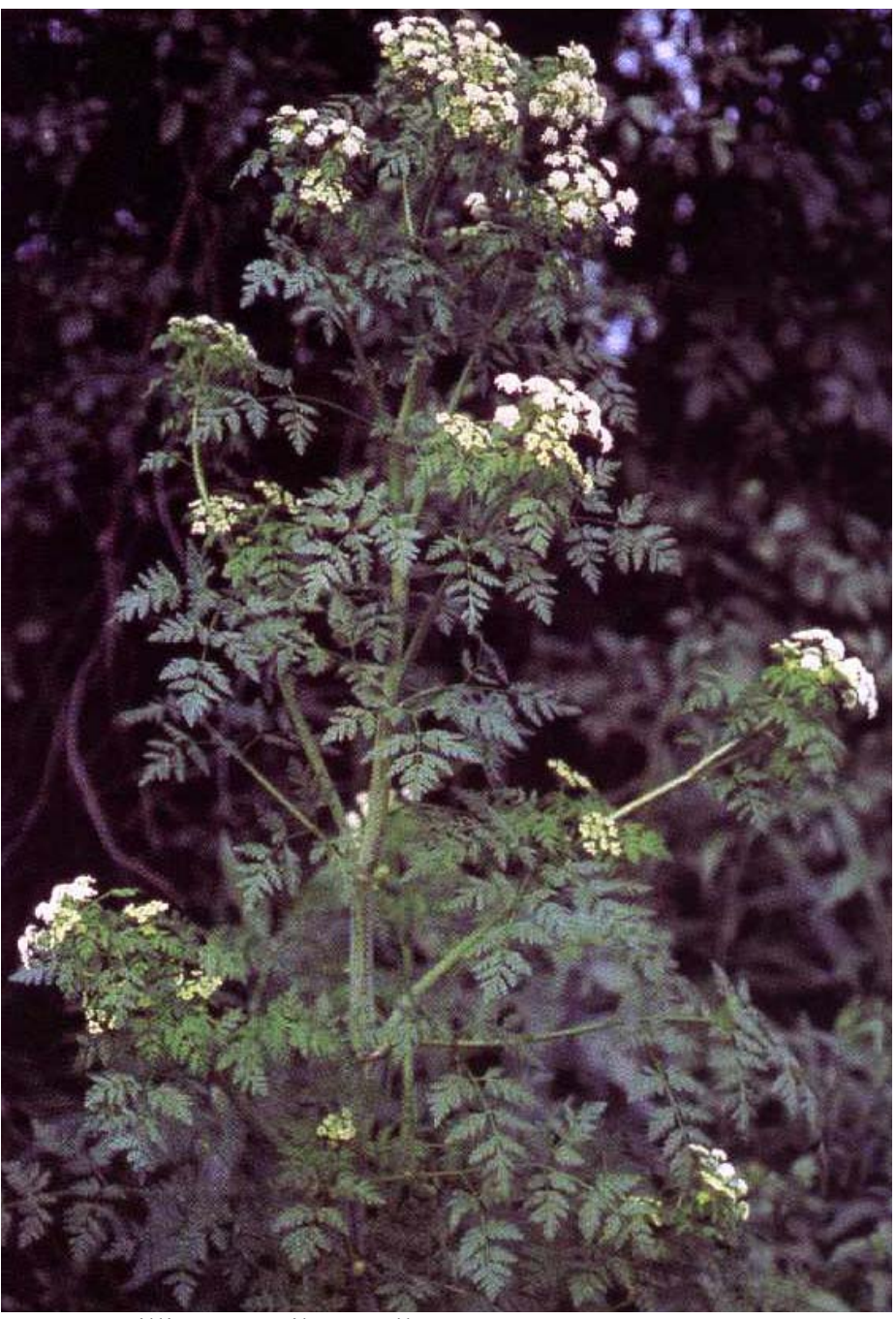

William \& Wilma Follette

USDA-NRCS PLANTS Database

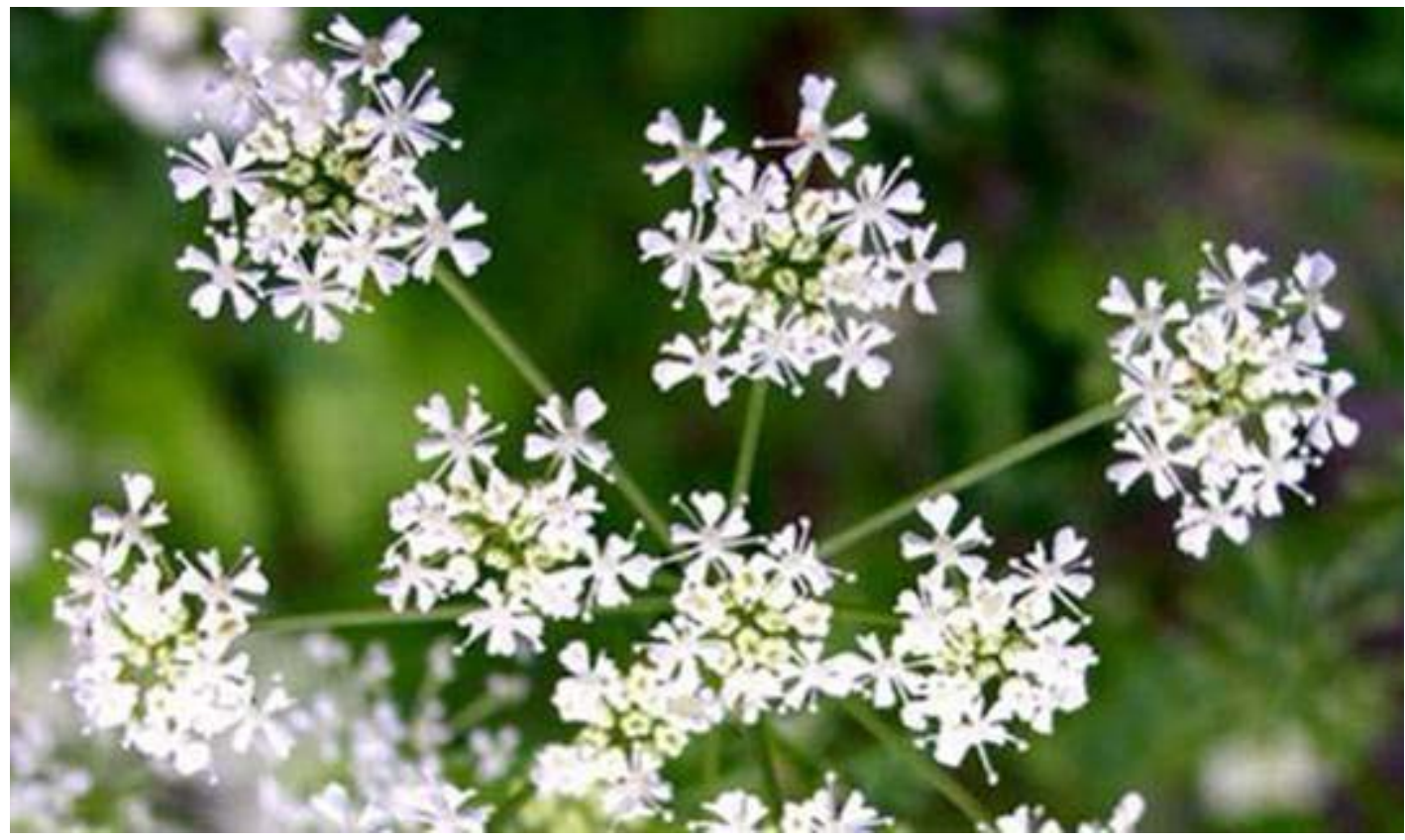

John R. Evans, photographer

University of Tennessee, Knoxville 
Cotula coronopifolia (Brass buttons)

- Perennial herb, not native

Stems

- Prostrate or decumbent, $8-50 \mathrm{~cm}$

- Smooth, hairless and somewhat succulent

- Lateral stems erect to ascending, rooting at the nodes

Leaves

- Alternate, 2-7 cm long

- Linear to oblong or lanceolate

- Deeply toothed to pinnately lobed, the lobes linear to lanceolate

- Leaf base is tapered, sheathing the stem Inflorescence (March-December)

- Disc-shaped, 6-15 mm wide

- Stalked, solitary and terminal



Reny Parker

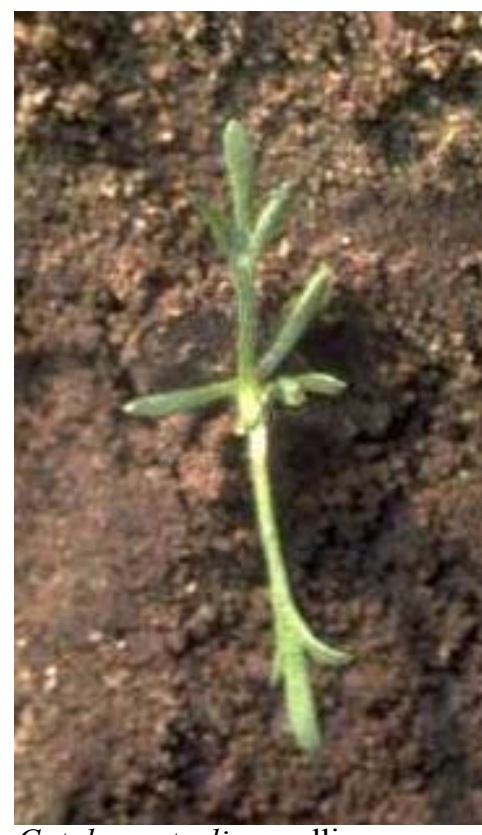

Cotula australis, seedling

(C) 2000 Regents, University of CA www.renyswildflowers.com UC Statewide IPM Program Bill Fischer, photographer

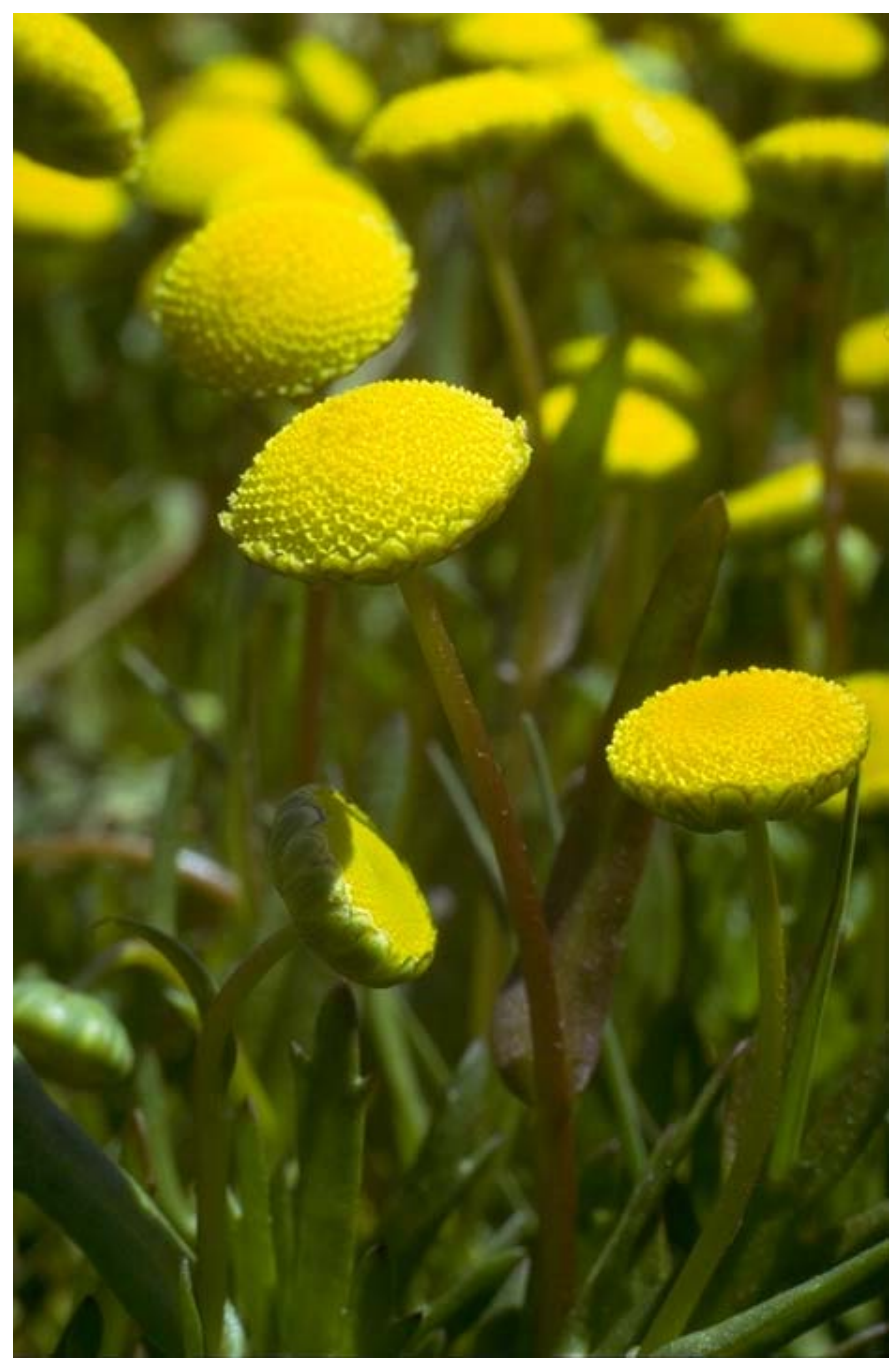

(C) 1999 California Academy of Sciences Albert P. Bekker, photographer

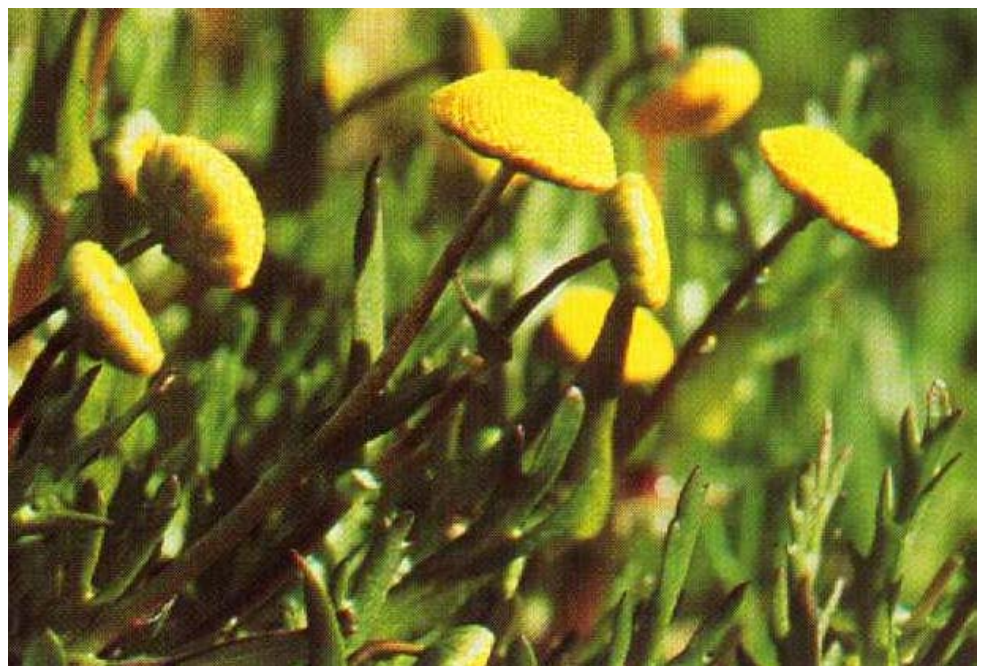

1992 William \& Wilma Follette

USDA-NRCS PLANTS Database 
Cressa Truxillensis (Alkali weed)

\section{Stems}

- Upright or lying flat (highly variable)

- Usually sprawling, but not twining

- 7-25 cm, many branches from base

- Densely covered in fine, silky, grayish-white hairs

Leaves

- Alternate, simple, no teeth

- Generally less than $1 \mathrm{~cm}$ long

- More or less sessile and elliptical in shape Inflorescence (May - October)

- Flowers solitary in axils of upper leaves

- 5 green sepals, 5 white petals that are the same length

- Calyx erect, concealing corolla tube

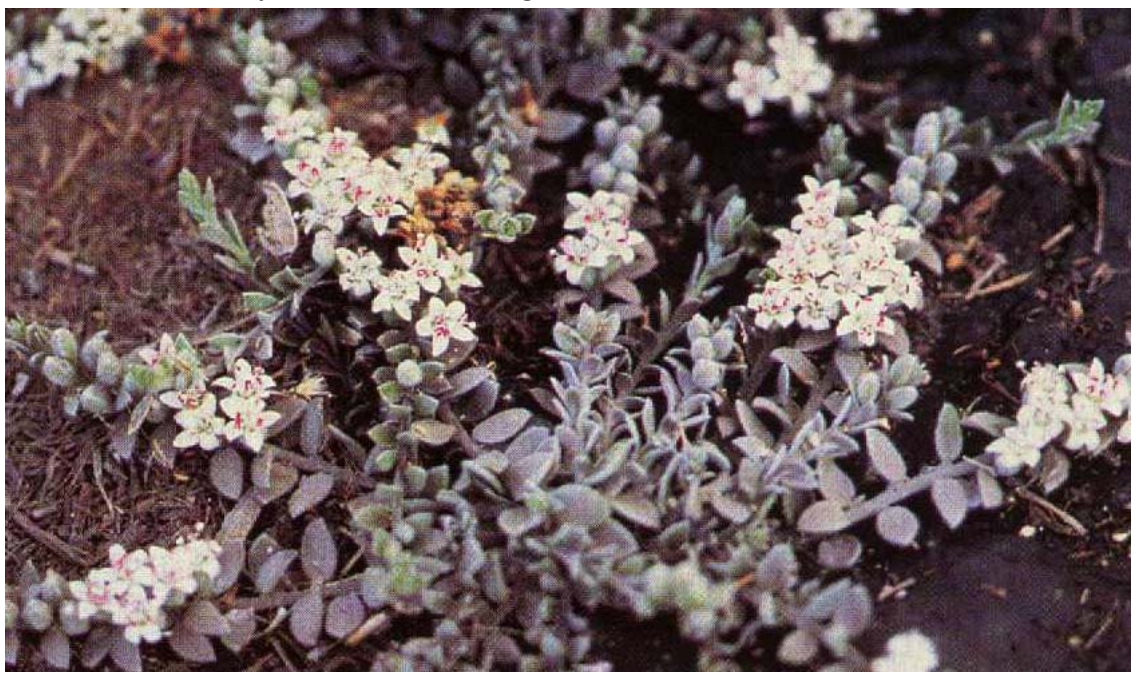

William \& Wilma Follette

USDA-NRCS PLANTS Database

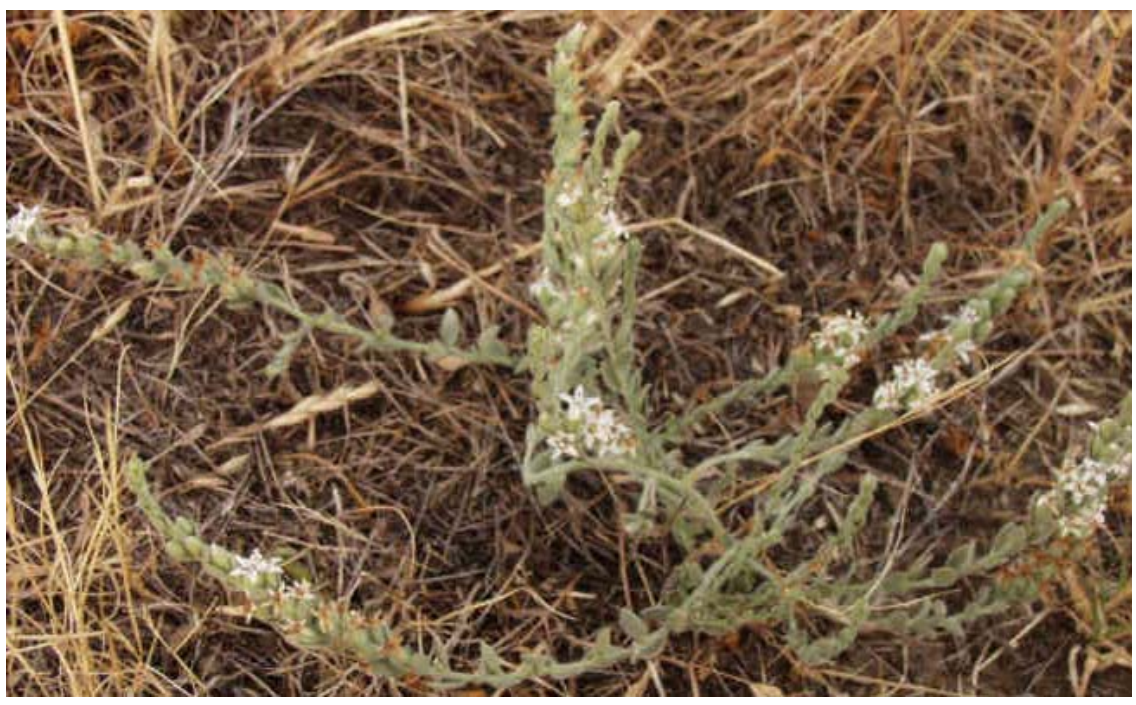

(C) 2001 James Reiter

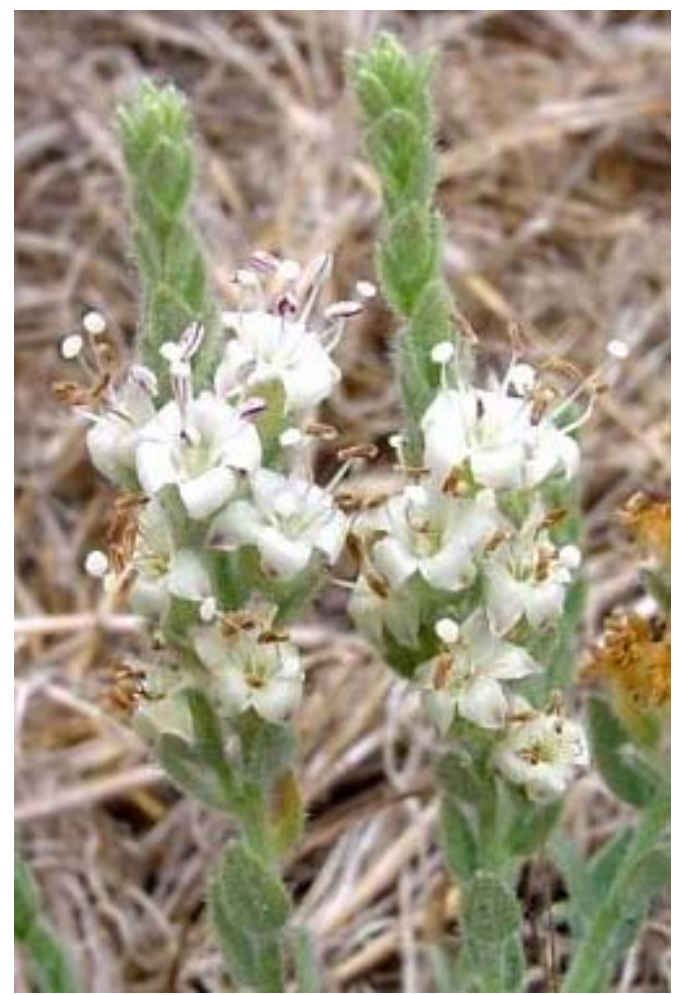

Michael Charters, www.calflora.net

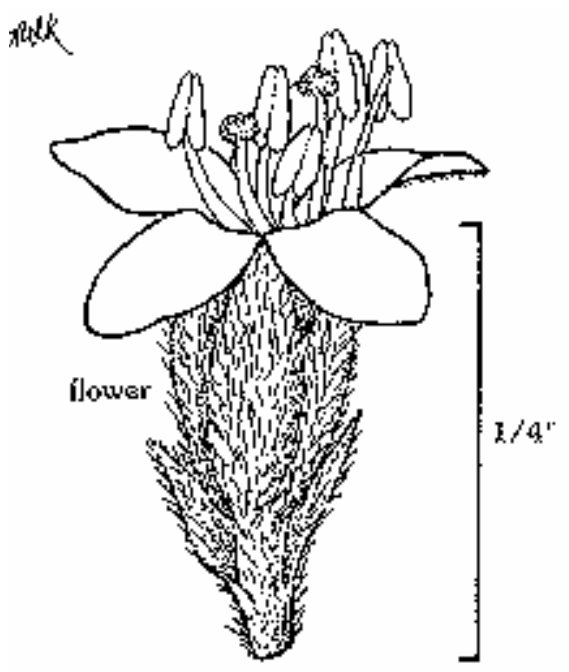

USGS, Northern Prairie Wildlife Research Center 
Crypsis Schoenoides (Swamp timothy)

- Annual, not native

Stems

- Decumbent (trailing on the ground and rising at the tip)

- $\quad 5-75 \mathrm{~cm}$

- Few branches

Leaves

- Ligule is hairy

- $\quad$ Blade is 2-10 cm, linear or narrowly lanceolate

- $\quad$ Sheath is wide, smooth and hairless Inflorescence

- 3-75 mm, 5-15 mm wide

- $\quad$ Egg-shaped to cylindrical

- Partly enclosed by subtending sheath Spikelet

- $3 \mathrm{~mm}$

- Glumes, lemma acute or short-pointed

- Glume margin is smooth and hairless

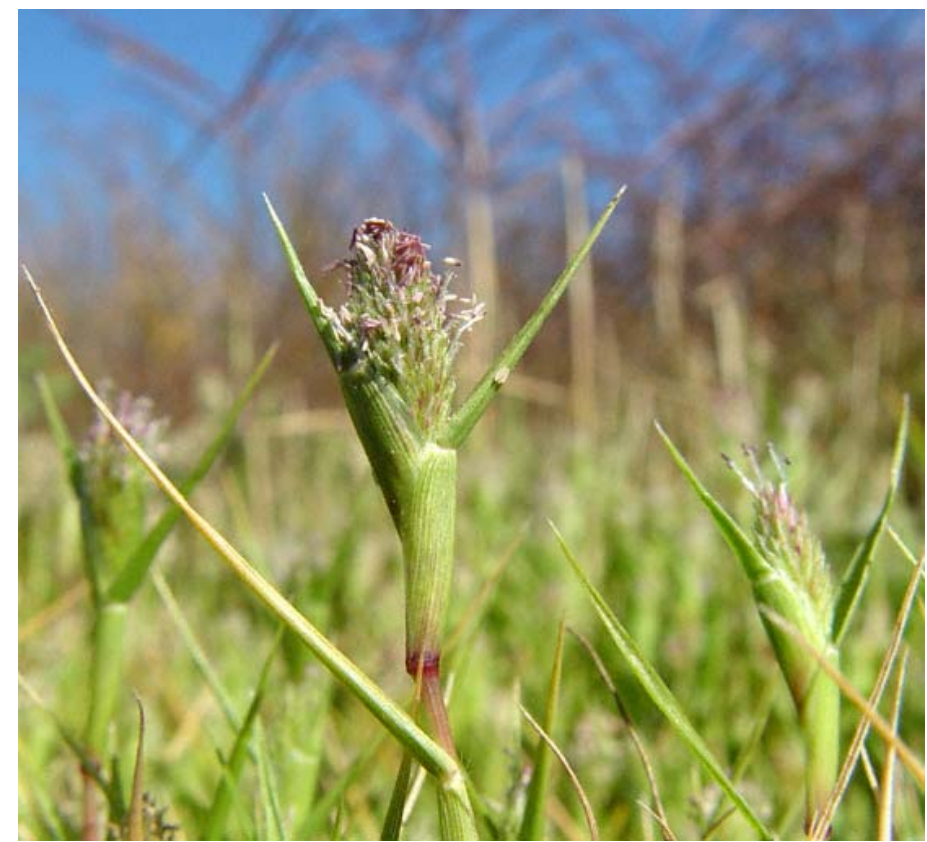

(C) 2003 George W. Hartwell
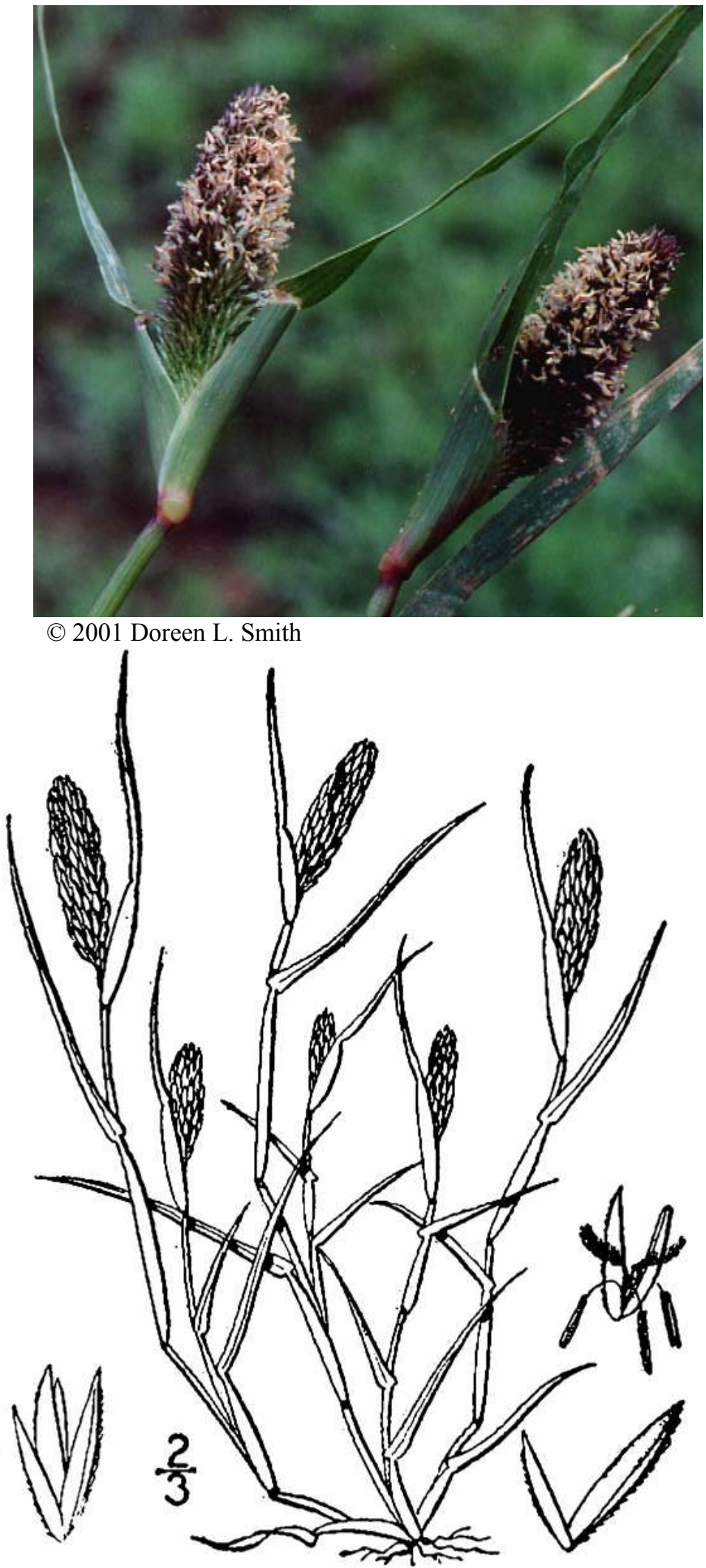

1913 Britton, N.L., and A. Brown USDA-NRCS PLANTS Database 
Cynodon dactylon (Bermuda grass)

- Not native, perennial that grows from rhizomes or stolons

- Mat-like growth

Stems

- 1-4 dm long

- Generally branched and erect

Leaves

- Short, flat, narrow and fleshy

- Blade less than $6 \mathrm{~cm}$ long

- Ligules are white-hairy

Inflorescence

- $\quad 4-7$ branches that are $2 \frac{1}{2}-5 \mathrm{~cm}$ long

- Spikelets are very small with purplish glumes and hairy lemmas

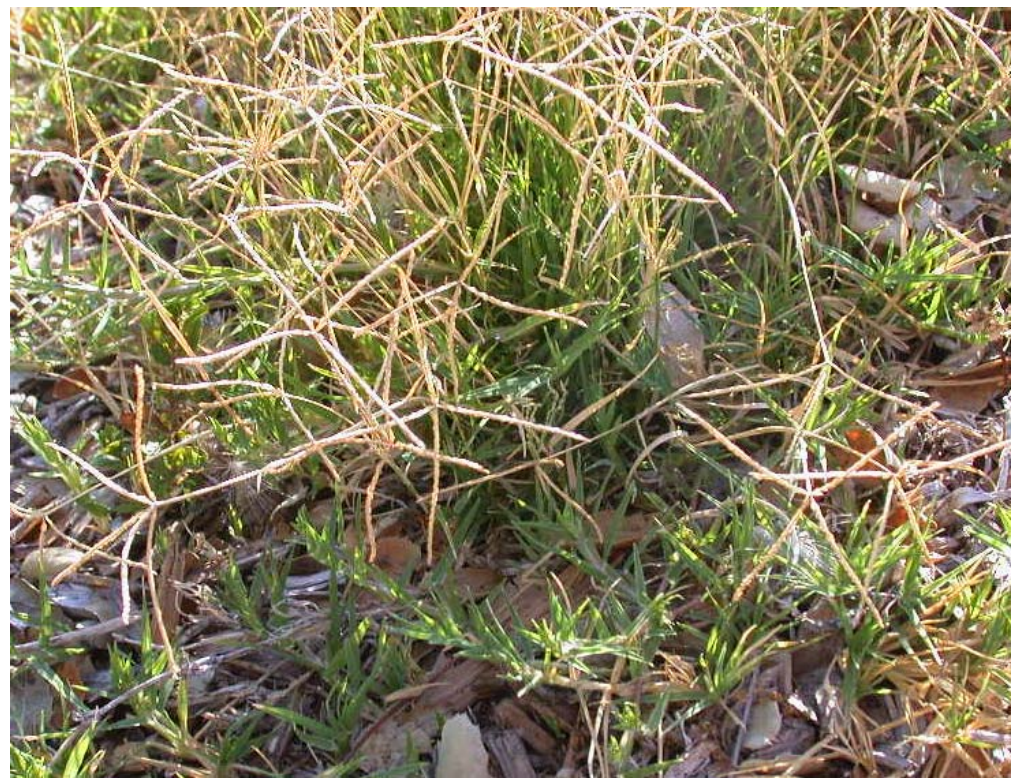

(C) 2001 Tony Morosco

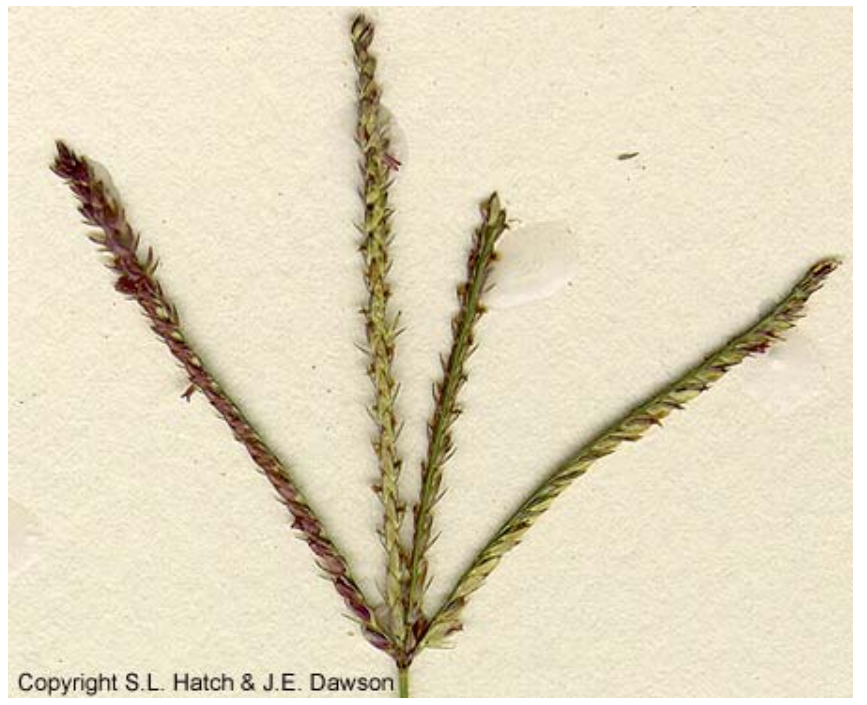

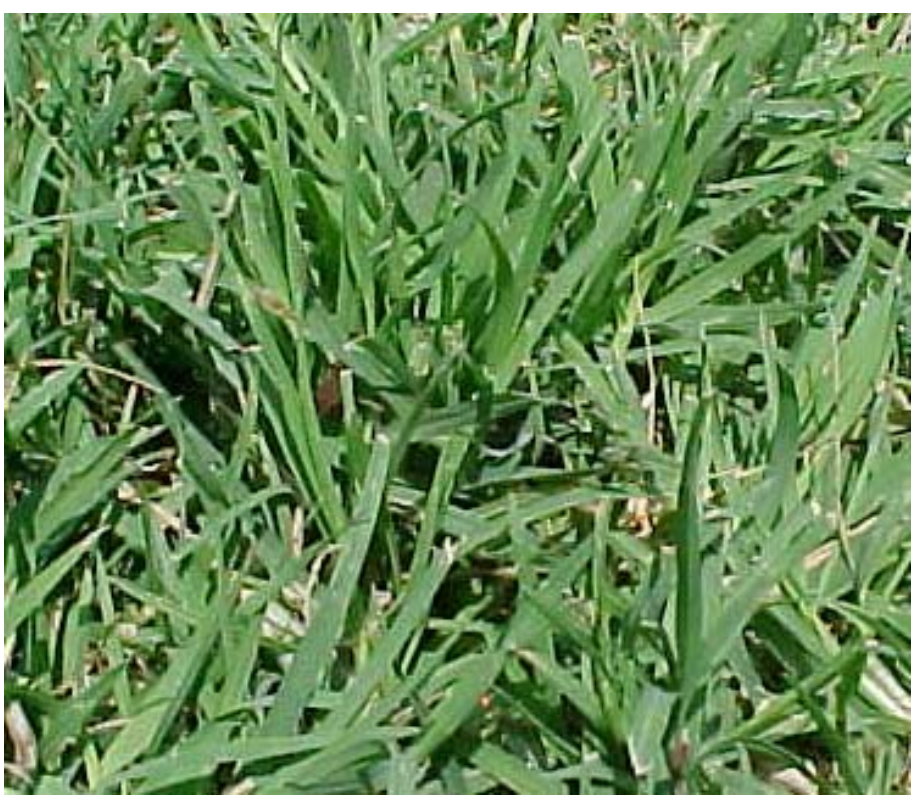

(C) 2001 Missouri Botanical Garden

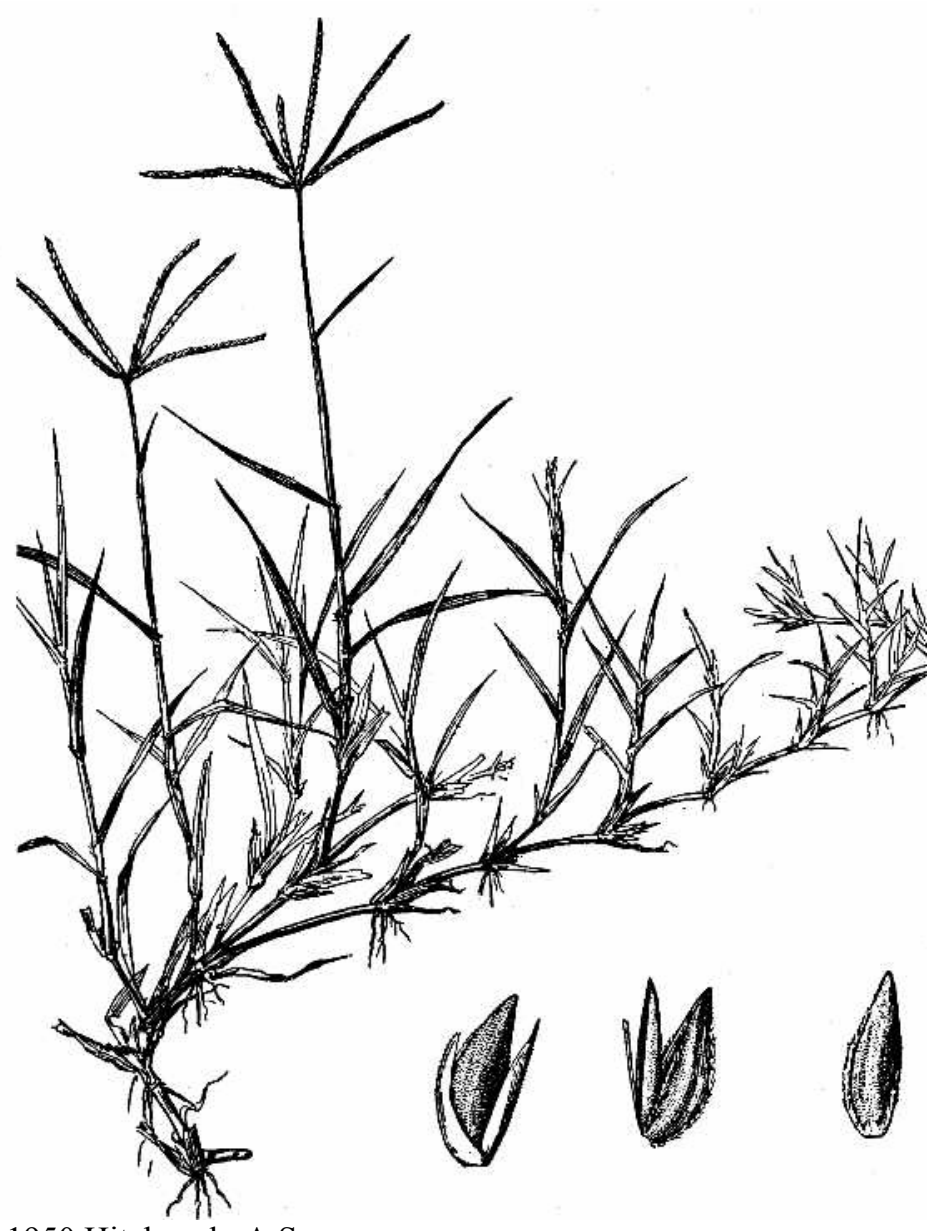

1950 Hitchcock, A.S.

USDA-NRCS PLANTS Database 
Cyperus esculentus (Chufa)

- Native perennial

- Low salinity tolerance

- Grows mainly from tubers formed on rhizomes, mostly in upper foot of soil

Stems

- Triangular in cross section

Leaves

- V-shaped in cross section

- Arranged in sets of three at the base Inflorescence

- 3-7 bracts, 5-10 rays

- Spikelets are linear, brown and in more or less open, widely elliptic spikes

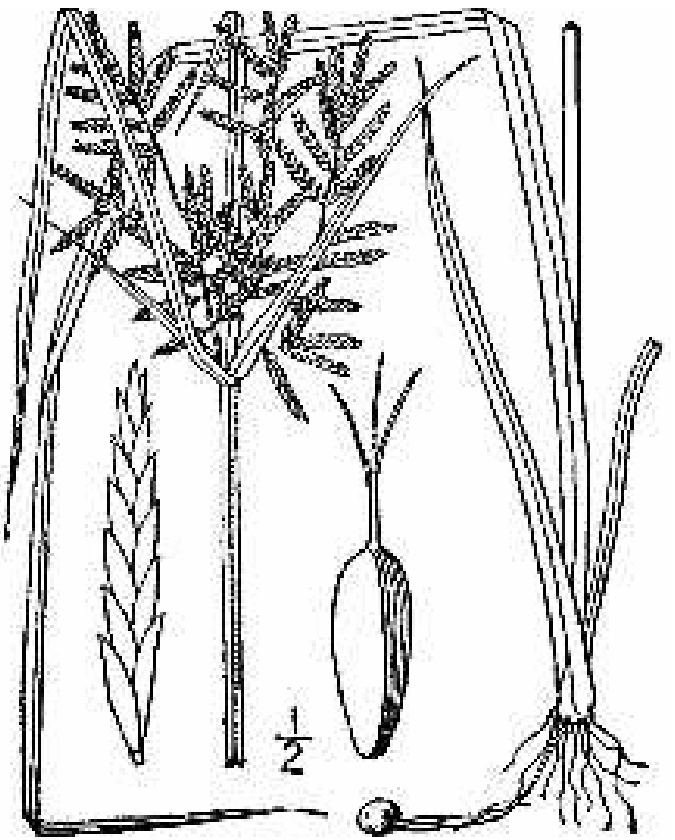

1913 Britton, N.L. and A. Brown USDA-NRCS PLANTS Database

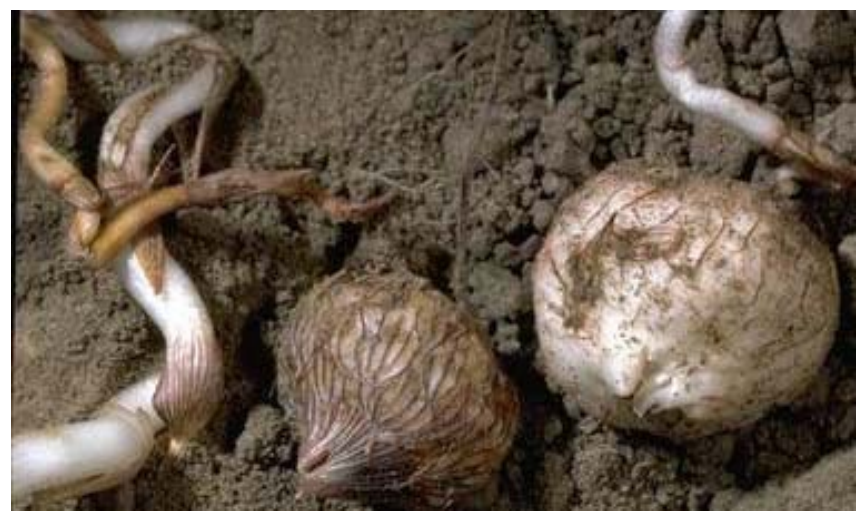

(C) 2000 Regents, University of California UC Statewide IPM Program Jack Kelly Clark, photographer

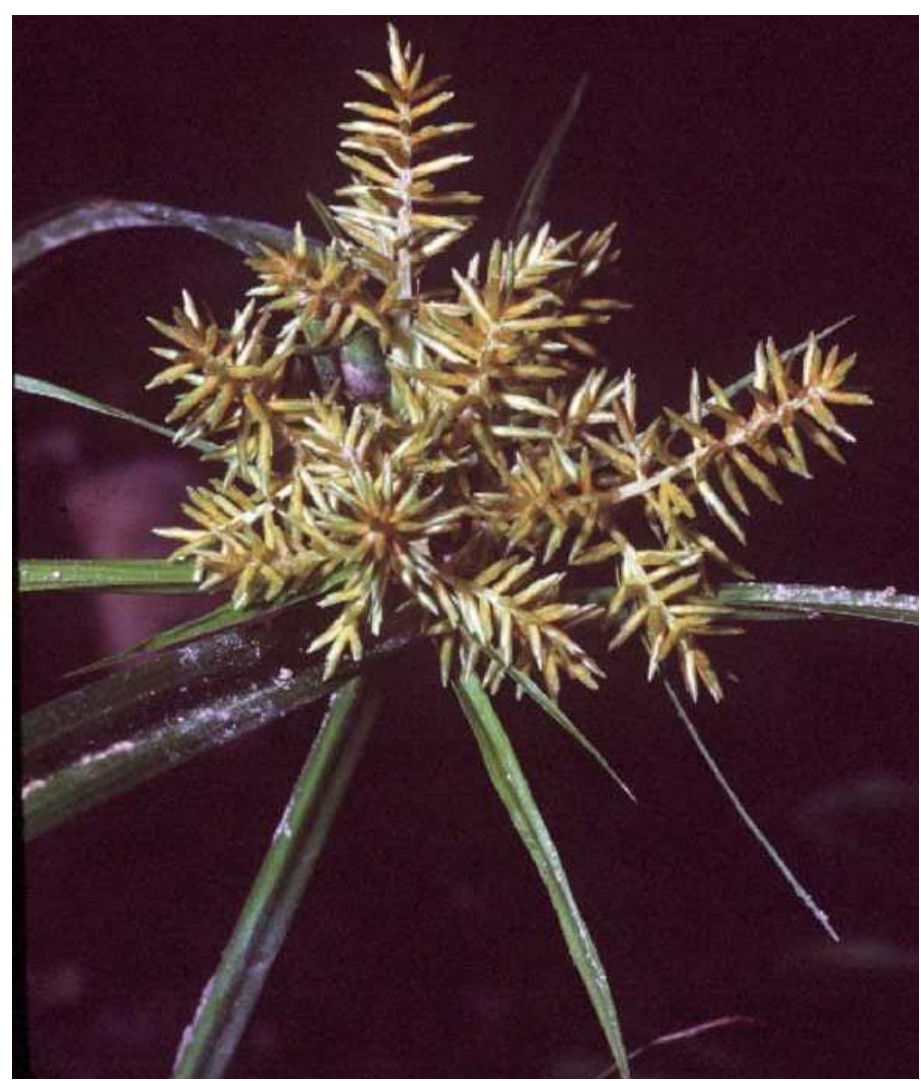

1989 Robert H. Mohlenbrock USDA-NRCS PLANTS Database

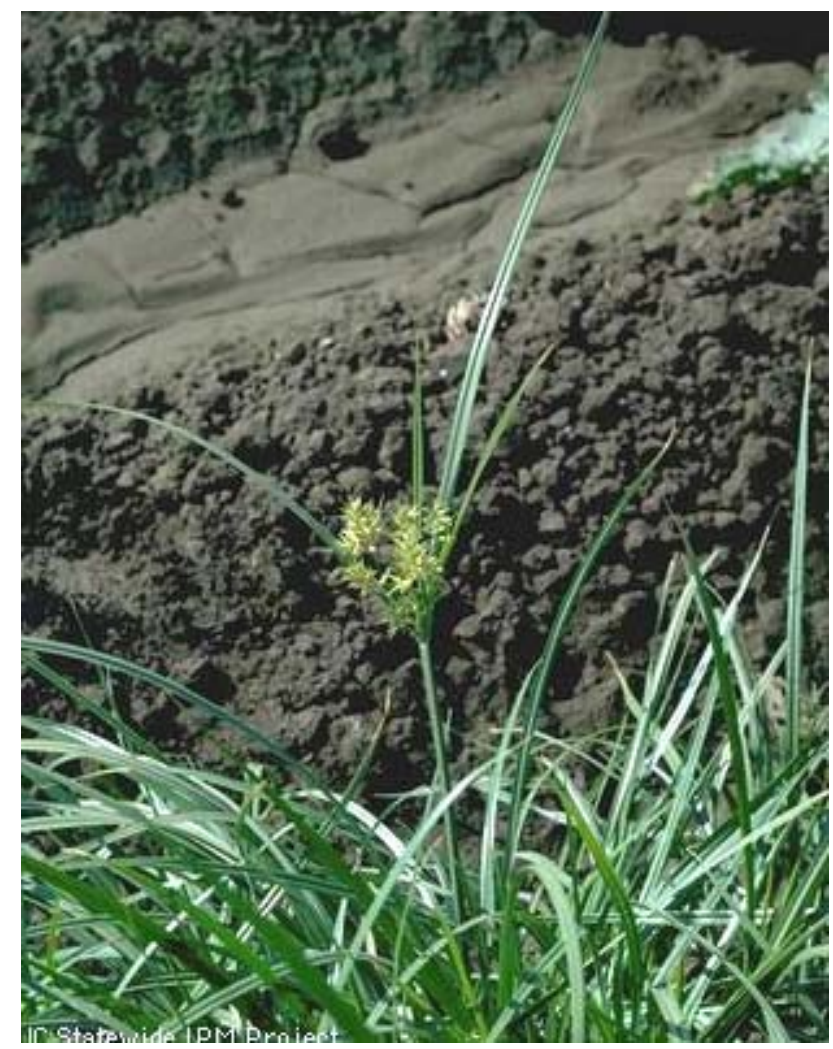

(C) 2000 Regents, University of California UC Statewide IPM Program Jack Kelly Clark, photographer 
Distichlis spicata (Saltgrass)

- Native perennial

- Grows from scaly rhizomes, stolons sometimes present

Stems

- Ascending to erect

- Smooth and hairless

Leaves

- Ligule membranous

- 2-10 cm long, 1-4 cm wide

- Stiff

Inflorescence

- Spikelet is 6-20 mm long

- Panicle or raceme-like

- Straw-colored to purplish

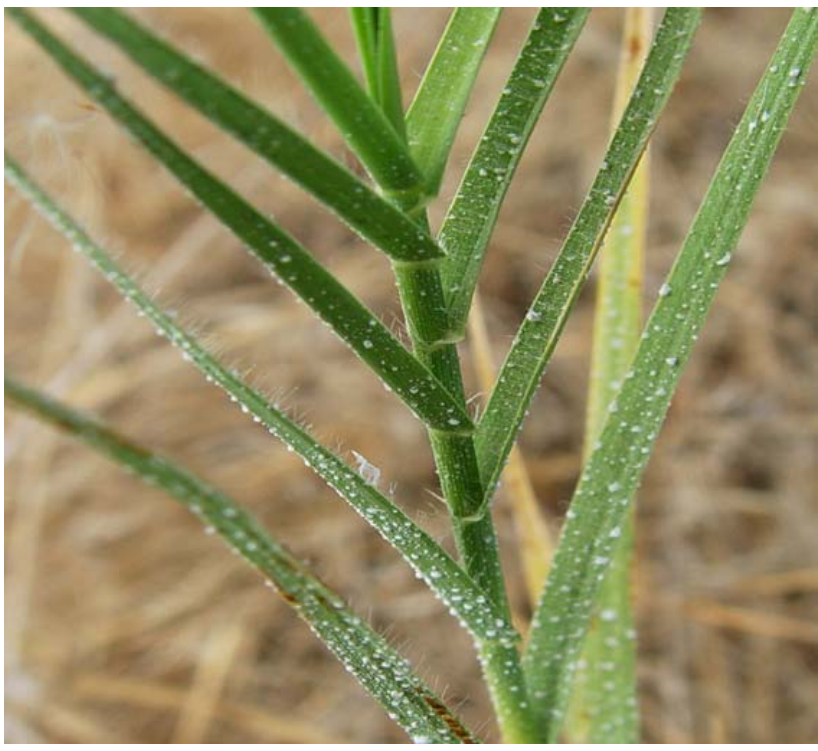

(C) 2003 George W. Hartwell

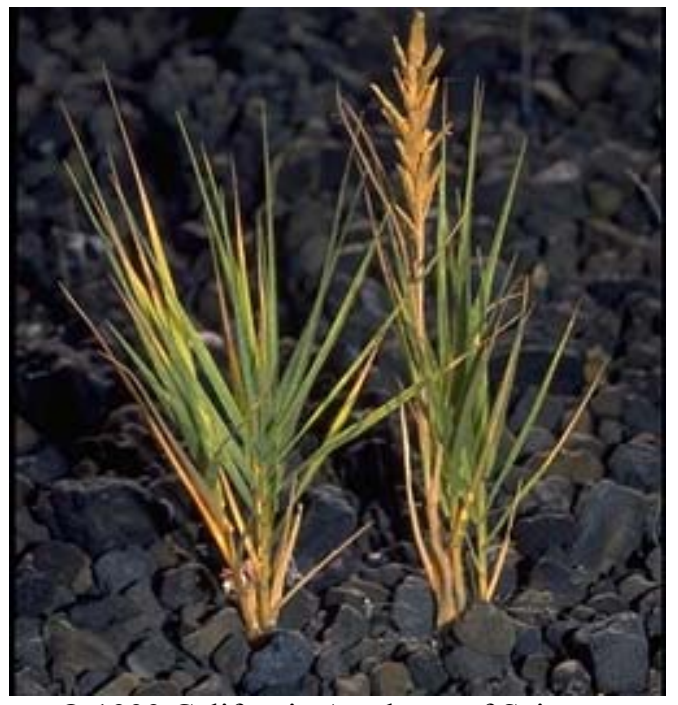

(C) 1999 California Academy of Sciences Gerald and Buff Corsi, photographers

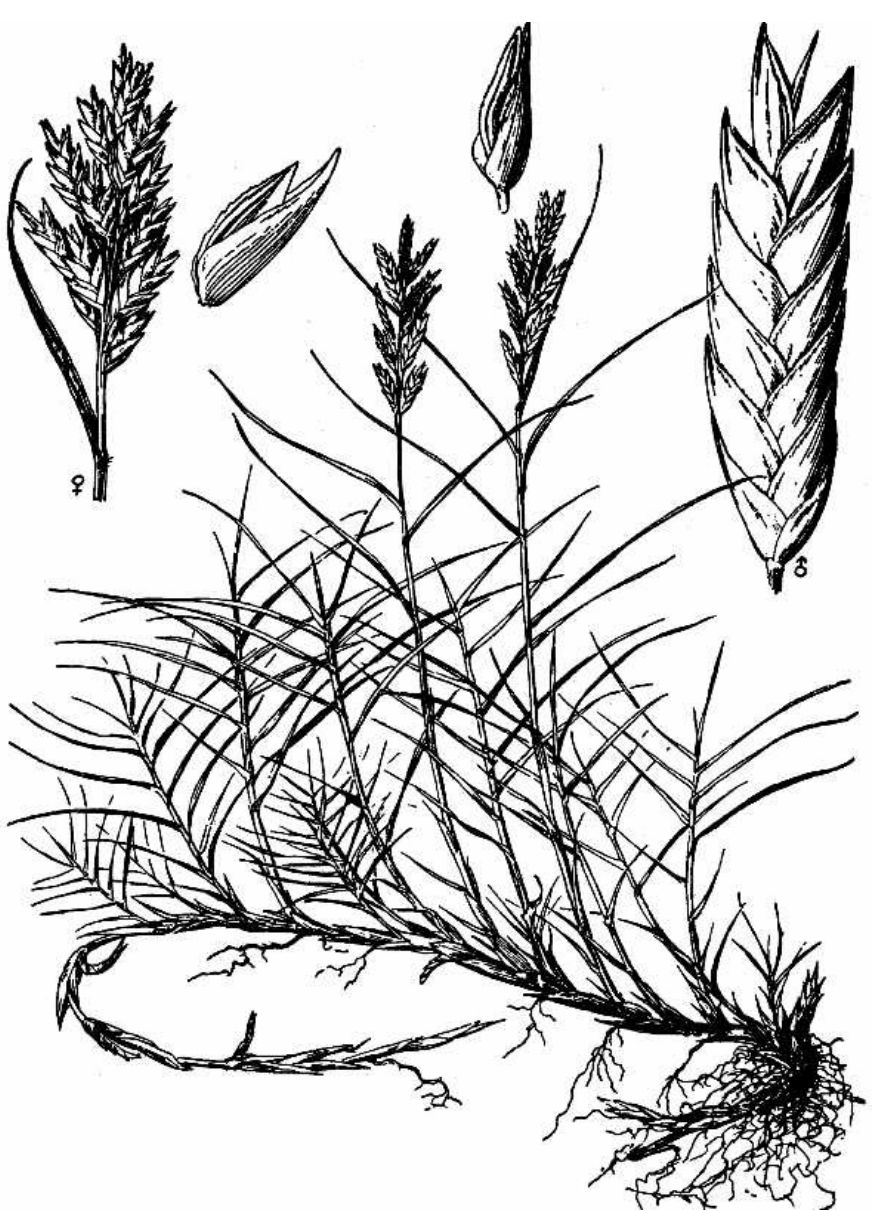

1950 Hitchcock, A.S.

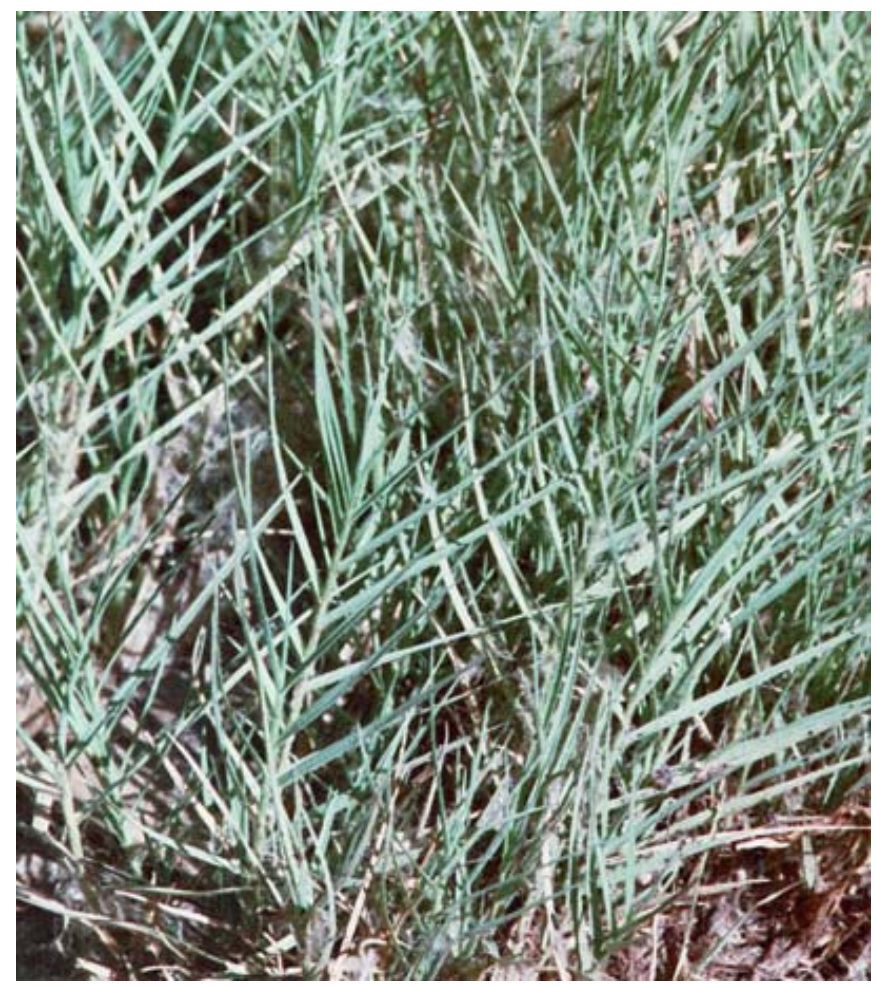

(C) 2001 Alison M. Sheehey 


\section{Downingia spp.}

- Endemic to vernal pools

- Annual herbs that germinates under water

Stems

- Decumbent to erect

- $20-40 \mathrm{~cm}$

Leaves

- Alternate, simple, narrowly lanceolate

- Up to $2 \frac{1}{2} \mathrm{~cm}$ long, pointed at the tip, tapering to the base and smooth, w/o teeth

- Range from $1 / 2-2 \mathrm{~mm}$ wide

Flower

- 5 petals with upper 2 smaller than lower 3

- 7-18 mm diameter

- Mainly blue with white, yellow or other colors

- Flowers sessile, but appear stalked because of the very slender floral tube

- Downingia bicornuta usually has larger flowers than the other two species

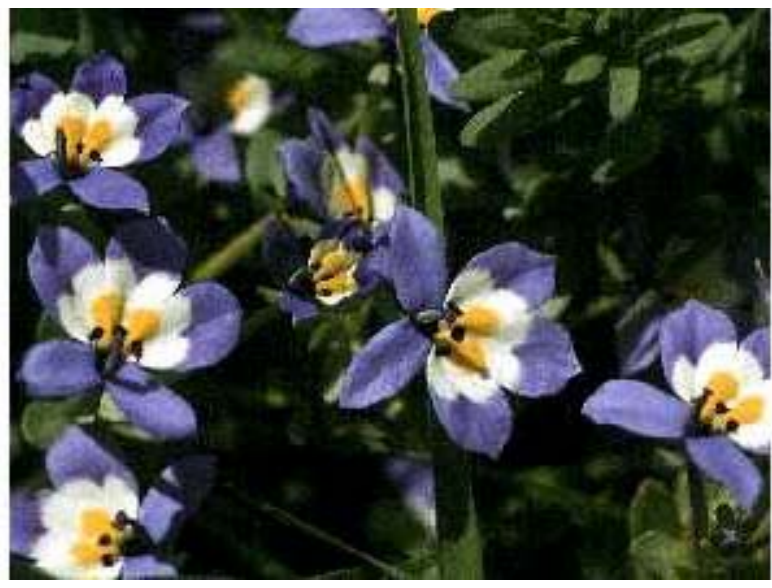

Downingia pulchella

(C) Saint Mary's College of California

Br. Alfred Brousseau, photographer

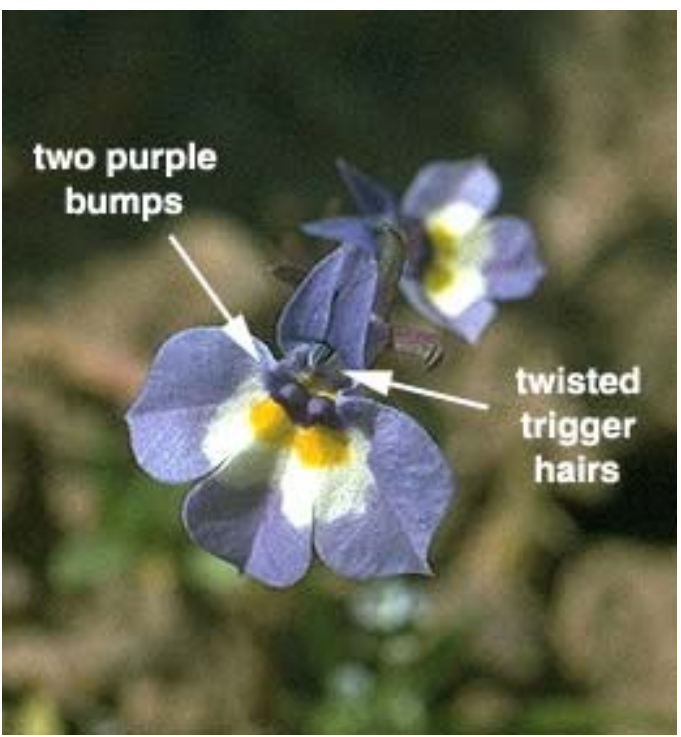

Downingia bicornuta

(C) Saint Mary's College of California Br. Alfred Brousseau, photographer

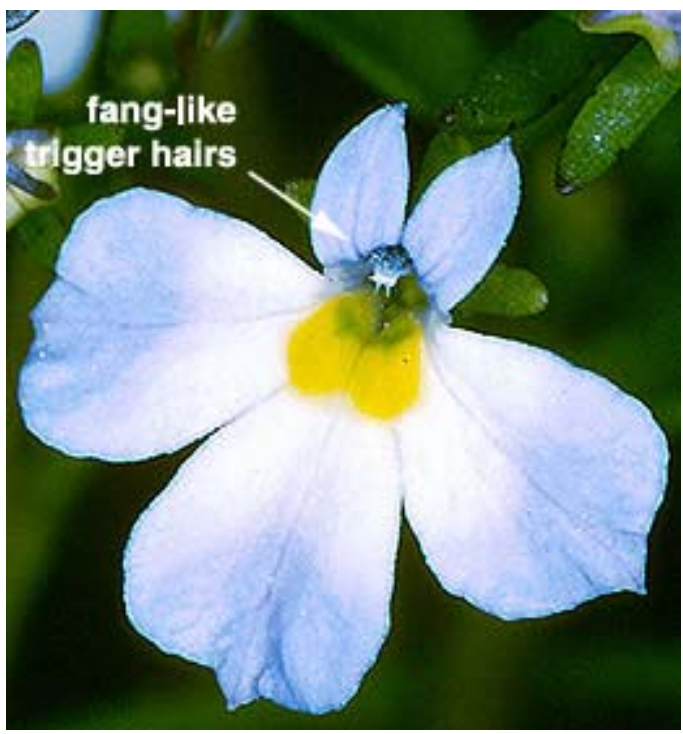

Downingia cuspidata

(C) John Game 
Echinochloa crusgalli (Watergrass)

- Annual

Stems

- Usually erect, thick, without hairs, often branched at the lower nodes

- May be tinted red to maroon at the base

- Stems of young plants often grow outward along the ground before turning upward

- Stems are flattened near the base

Leaves

- Only common summer grass that has no hairs or membranes at the collar region and lacks a ligule and auricles

- Sheaths are 3-7 cm, blades are 1-30 cm Inflorescence

- Flower heads are extremely variable, but they often droop slightly with lower flower branches further apart than upper ones

- Terminal panicle $6-10 \mathrm{~cm}$ in length

- Panicles are green to purple in color and are comprised of individual spikelets that may develop a 2-10 $\mathrm{mm}$ long terminal awn

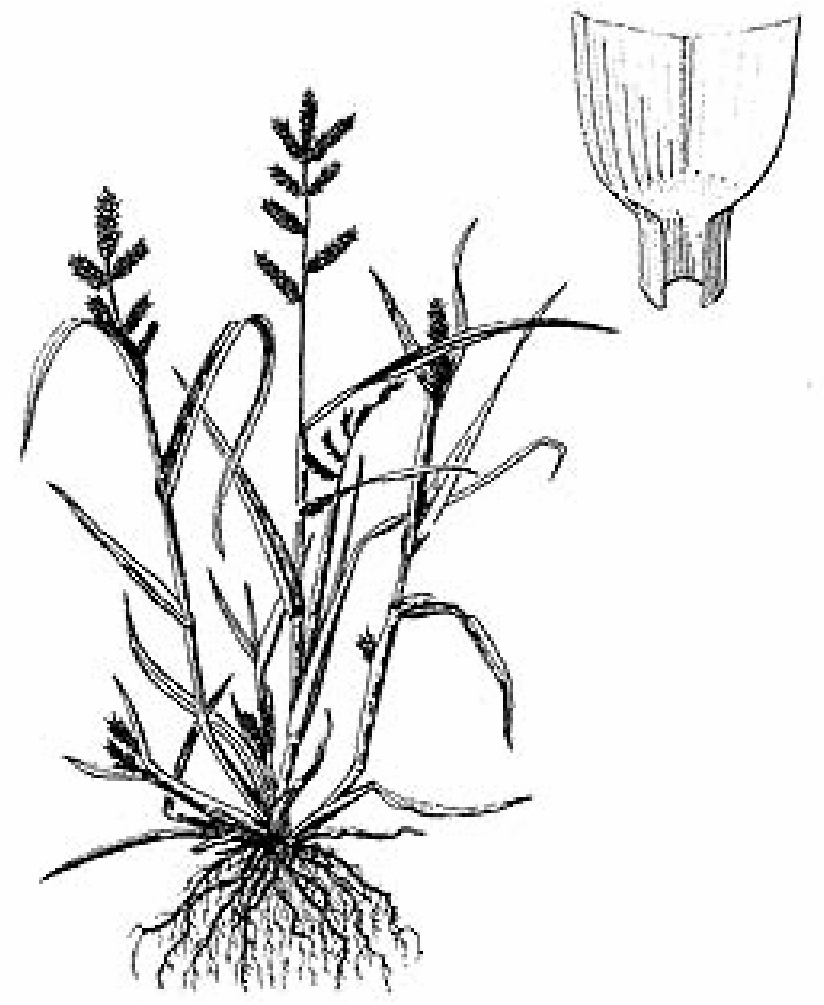

USDA Yearbook of Agriculture

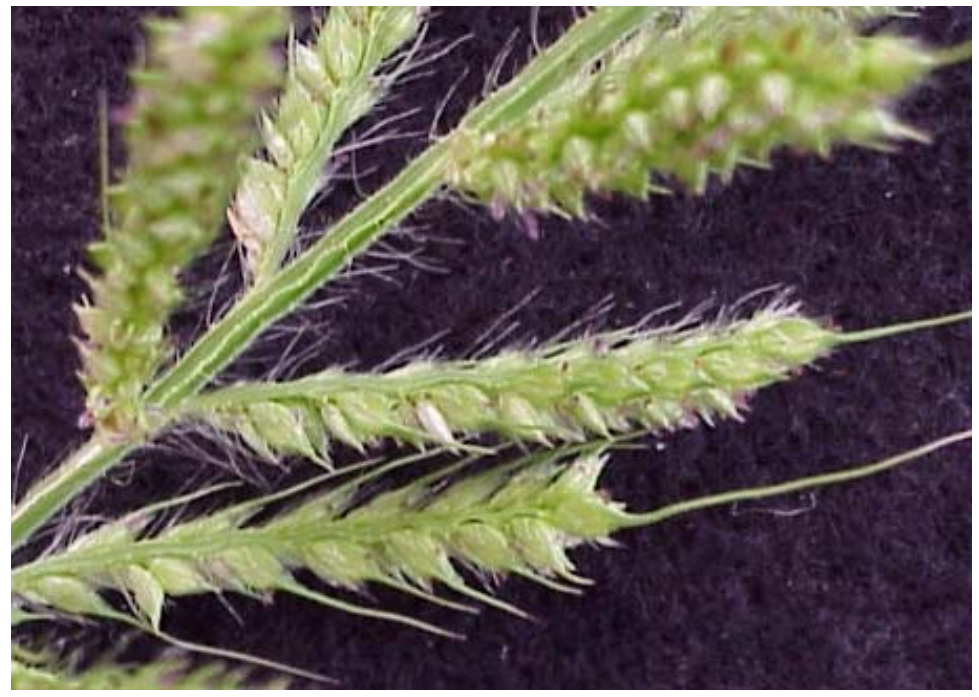

Virginia Tech Weed Identification Guide

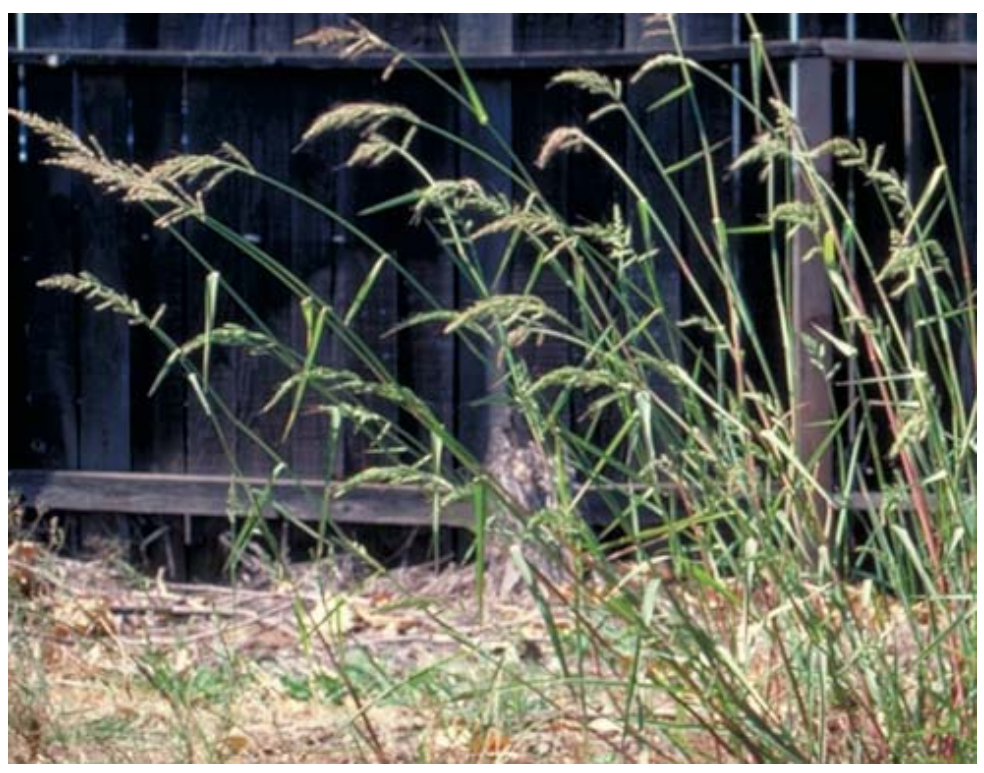

2001 California Dept. of Food \& Agriculture, Botany Lab

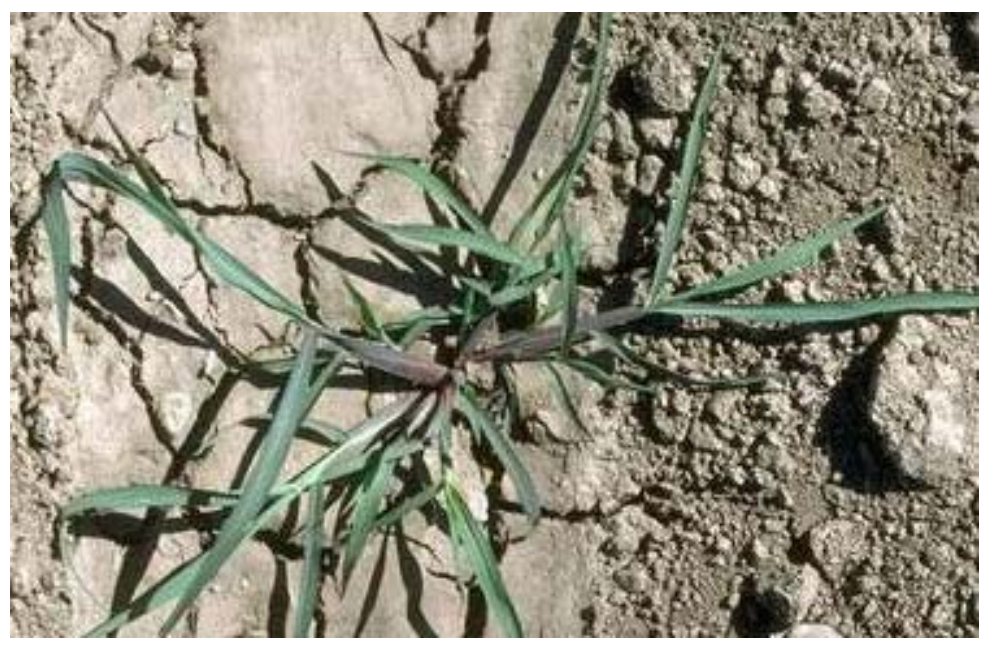

2000 Regents, University of California

UC Statewide IPM Program

Jack Kelly Clark, photographer 


\section{Echinodorus berteroi (Burhead)}

- Native annual or short-lived perennial

- Grows mostly from seed in shallowly flooded areas where the stand is thin

- Mature plant is 3-6 dm tall Leaves

- Long, angled petioles

- Blade with transparent lines, coarsely veined

- Emergent blades elliptic to heart-shaped at the base (6-14 cm long, 3-15 cm wide)

- Submerged blades linear and wavy

Inflorescence

- Flowers with 3 widely spaced white petals, and dark green sepals

- Generally more than 3 flowers per node

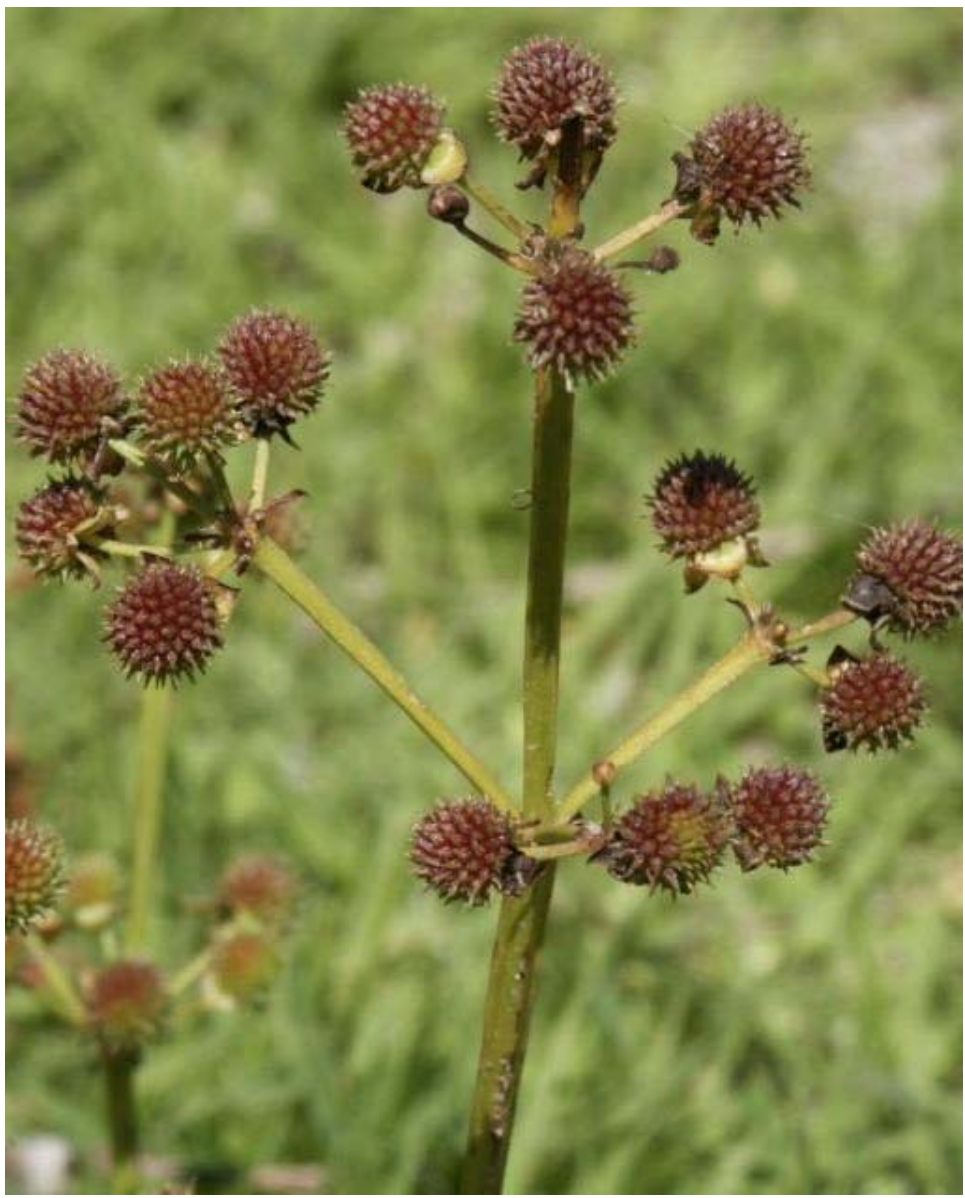

Michael Charters, www.calflora.net

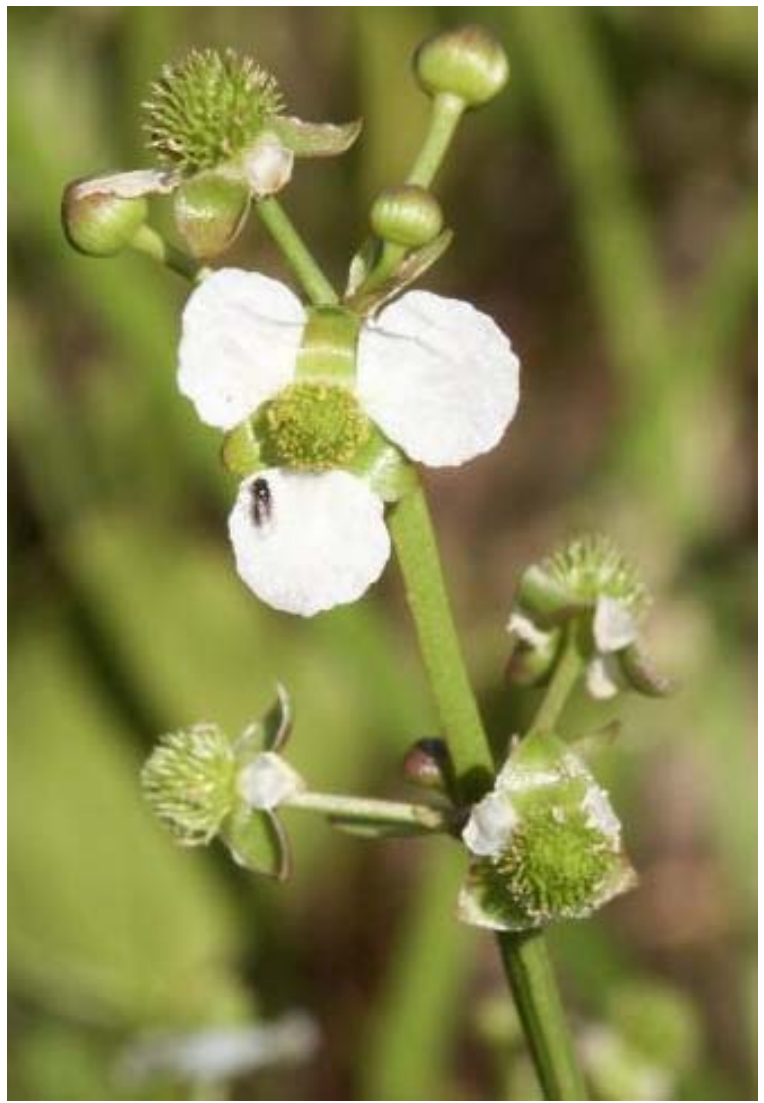

Michael Charters, www.calflora.net

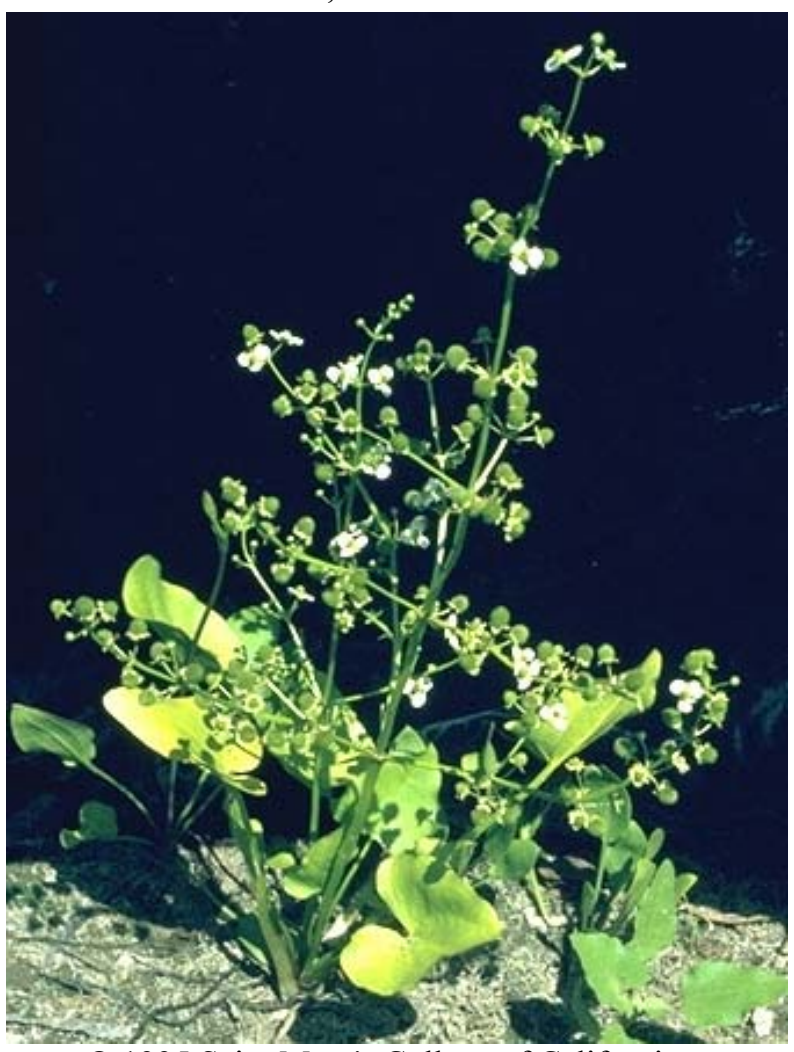

(C) 1995 Saint Mary's College of California

Br. Alfred Brousseau, photographer 


\section{Eleocharis spp. (Spikerush)}

- Usually found in shallow water, but submerged forms do occur

Stems

- Generally round, ridged and grooved

- Stems are usually cylindrical, but some may be triangular (E. obtusa)

- Generally solid

- Range in height from 1-12 dm with varying diameters

Leaves

- Leaves are reduced to a sheath at the base of the stem

- No blades

Inflorescence

- Mature stems are tipped with a brown to black, scaly, lance-shaped spikelet

- Spikelet is solitary, terminal and erect, w/o bract

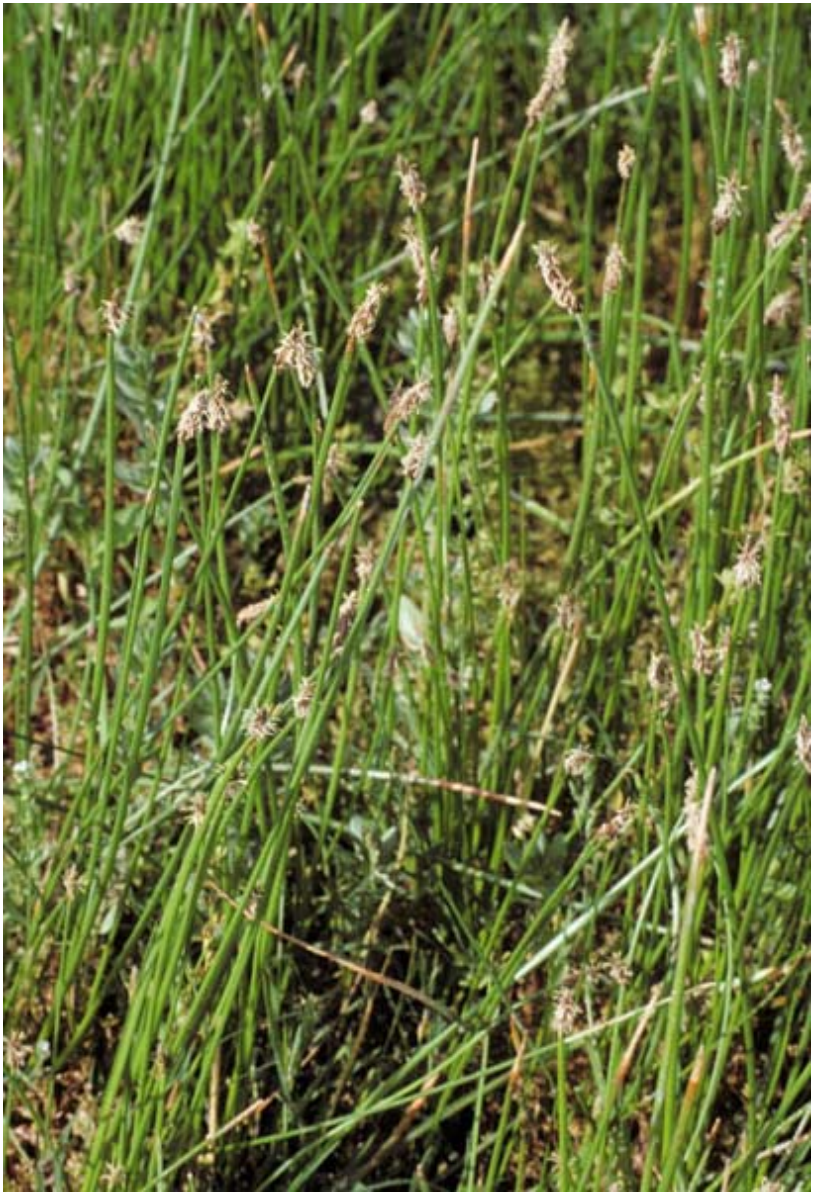

Eleocharis macrostachya

(C) 1992 Robert E. Preston, Ph.D



Eleocharis obtusa

University of California Statewide IPM Program Jack Kelly Clark, photographer

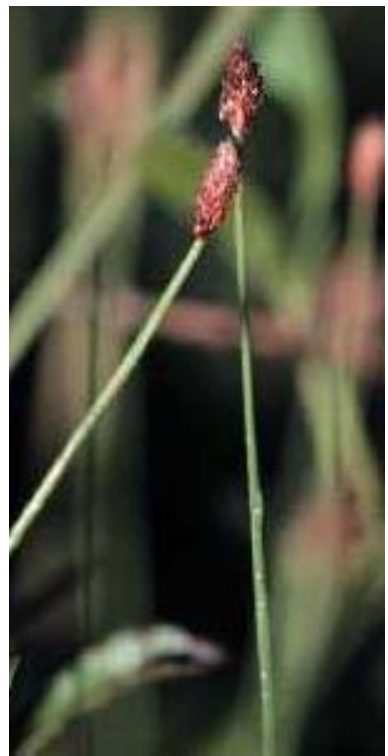

Eleocharis montevidensis

(C) Larry Allain

USDA-NRCS PLANTS Database

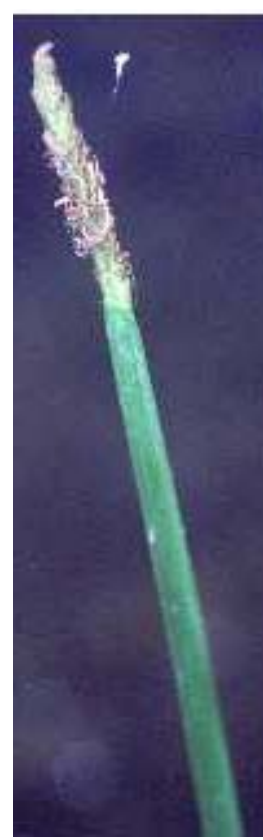

E. quadrangulata

Robert H. Mohlenbrock

USDA-NRCS PLANTS database 
Frankenia salina (Alkali heath)

- Perennial subshrub

Stems

- More or less prostrate

- 1-6 dm

- Twig smooth or hairy

Leaves

- Leaves are opposite and may be smooth to densely hairy

- $\quad$ The lower leaves are obovate (egg-shaped) and upper ones are narrow

- Axillary fascicles are often present

Inflorescence (June-October)

- Solitary rose-purple flowers are about $1 \mathrm{~cm}$ wide and are sessile in the upper leaf axils

- 5-cleft calyx is tubular with acute teeth, and the corolla contains 5 petals with 4-7 stamens

- Normally 3 style branches

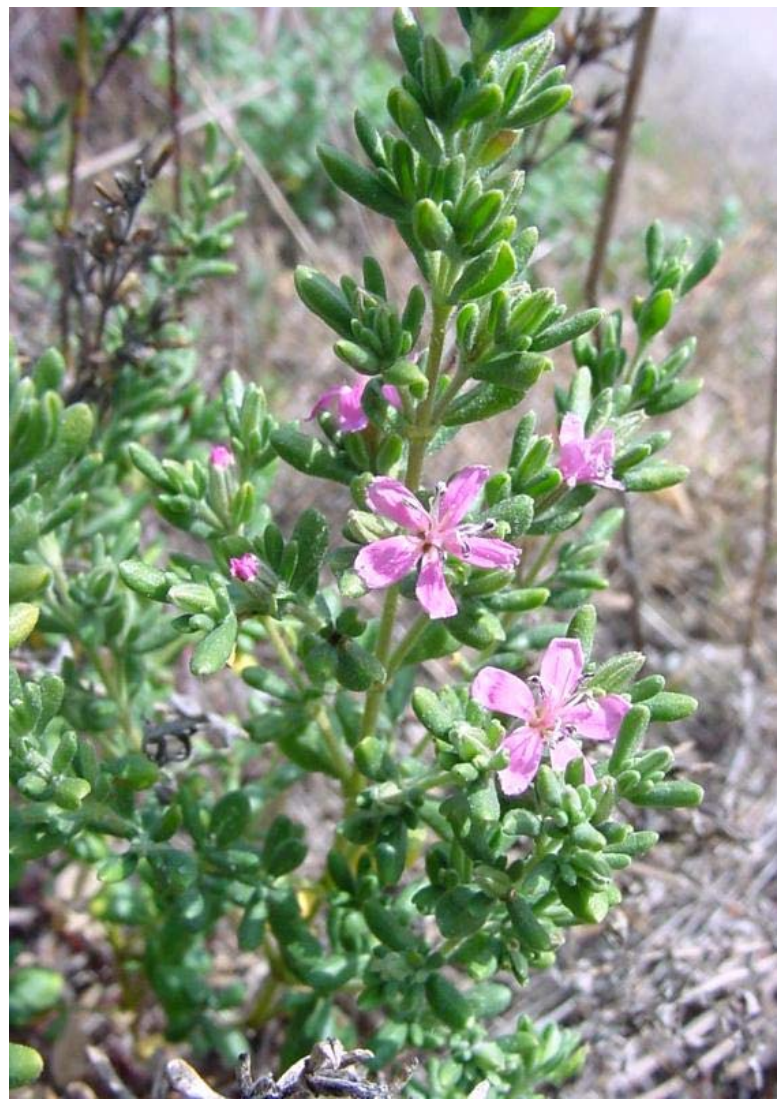

Michael Charters, www.calflora.net

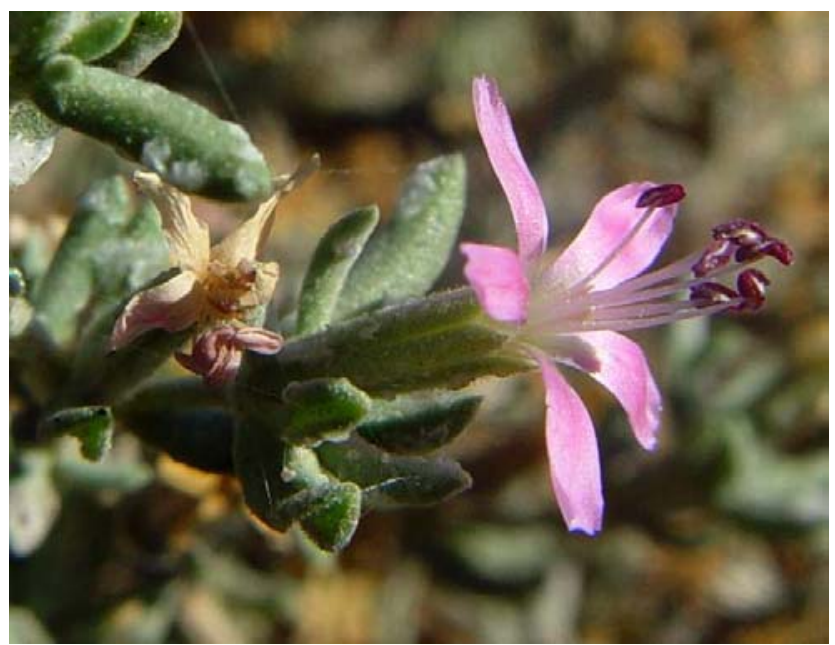

(C) 2002 Franco Folini

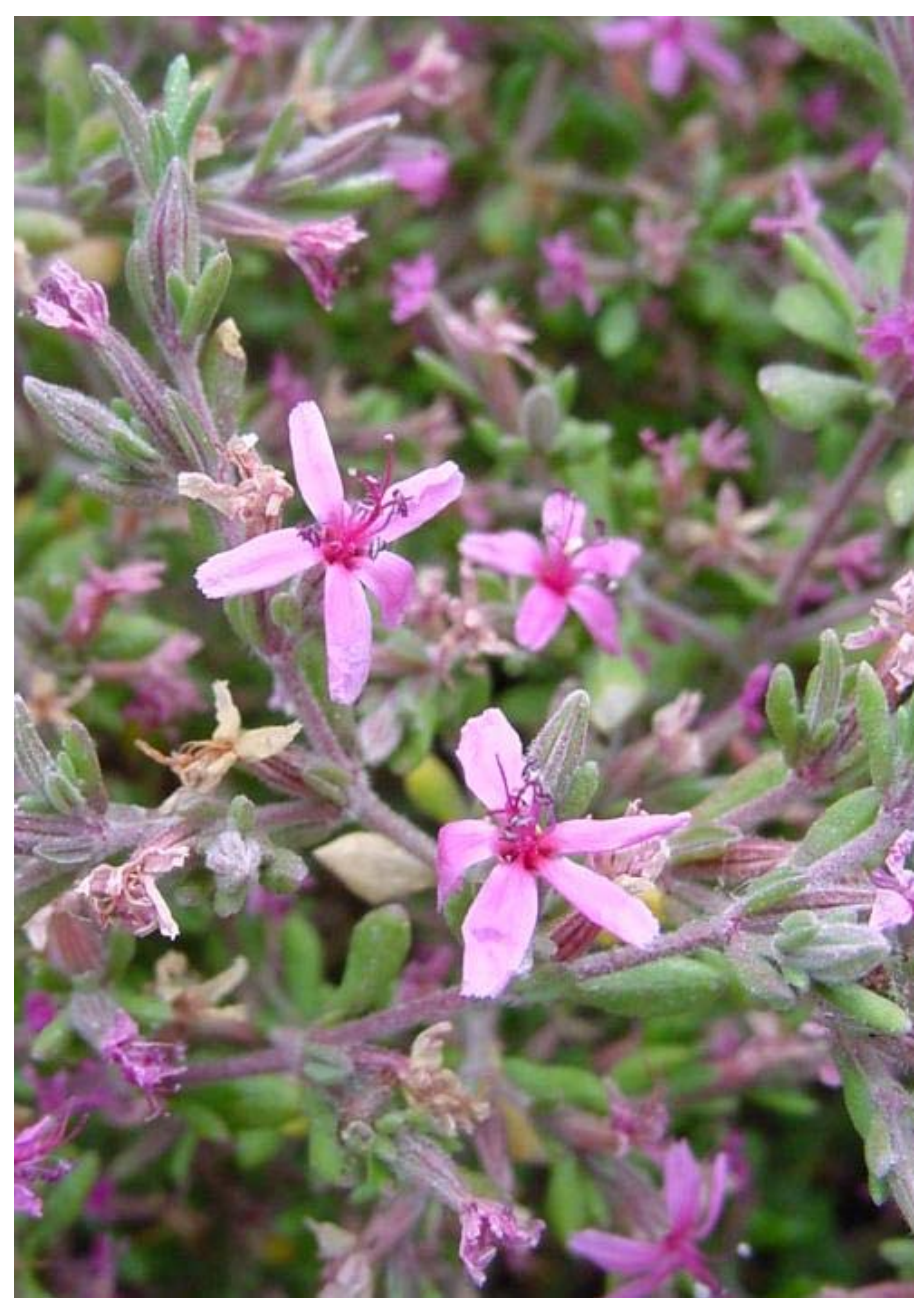

Michael Charters, www.calflora.net 
Grindelia squarrosa (Curlycup gumweed)

- Native biennial

- Toxic, concentrates selenium

Stems

- 1-6 dm tall

- Decumbent to erect, branched and hairless Leaves

- $\quad 1 \frac{1}{2}-7 \mathrm{~cm}$, oblong to ovate and dentate

- Gray-green and hairless

Inflorescence

- Heads sometimes subtended by bracts

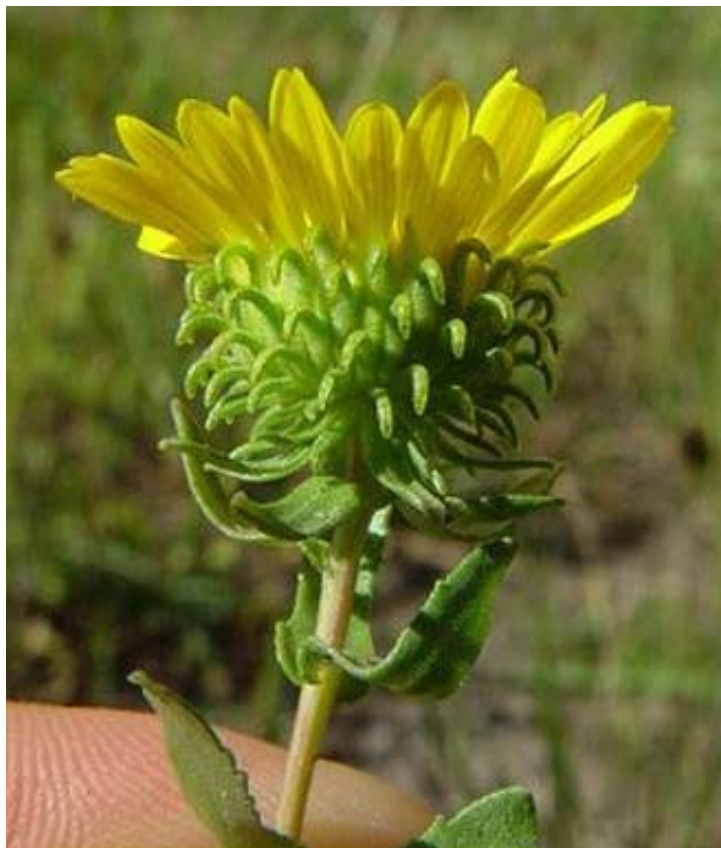

Dan Tenaglia, www.missouriplants.com

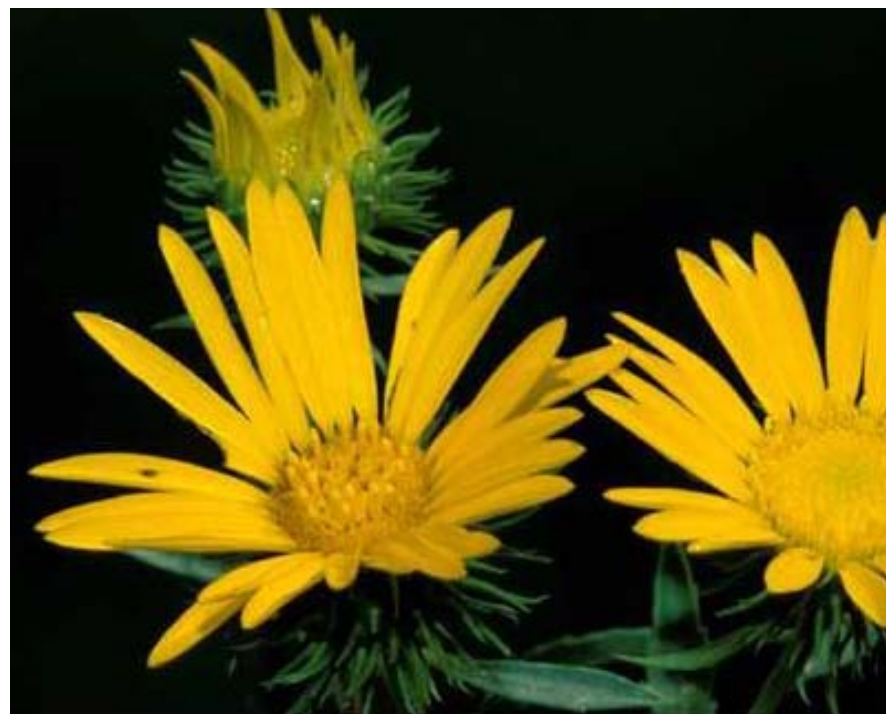

(C) 2004 Thomas G. Barnes

USDA-NRCS PLANTS Database

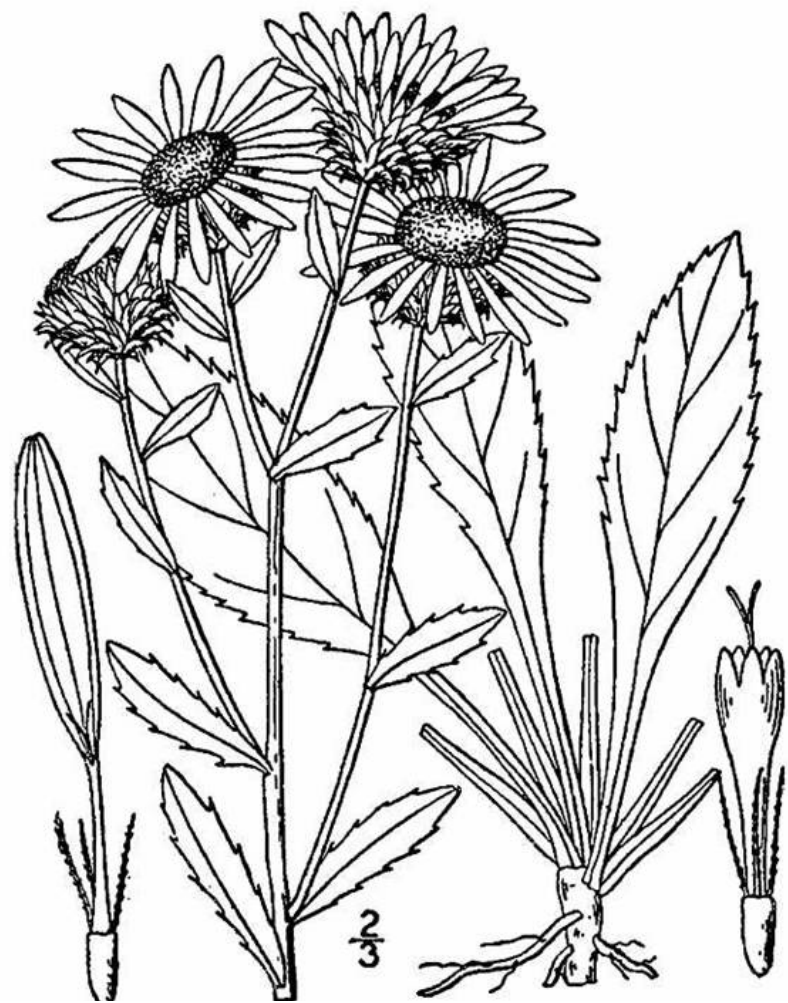

1913 Britton, N.L. and A. Brown USDA-NRCS PLANTS Database

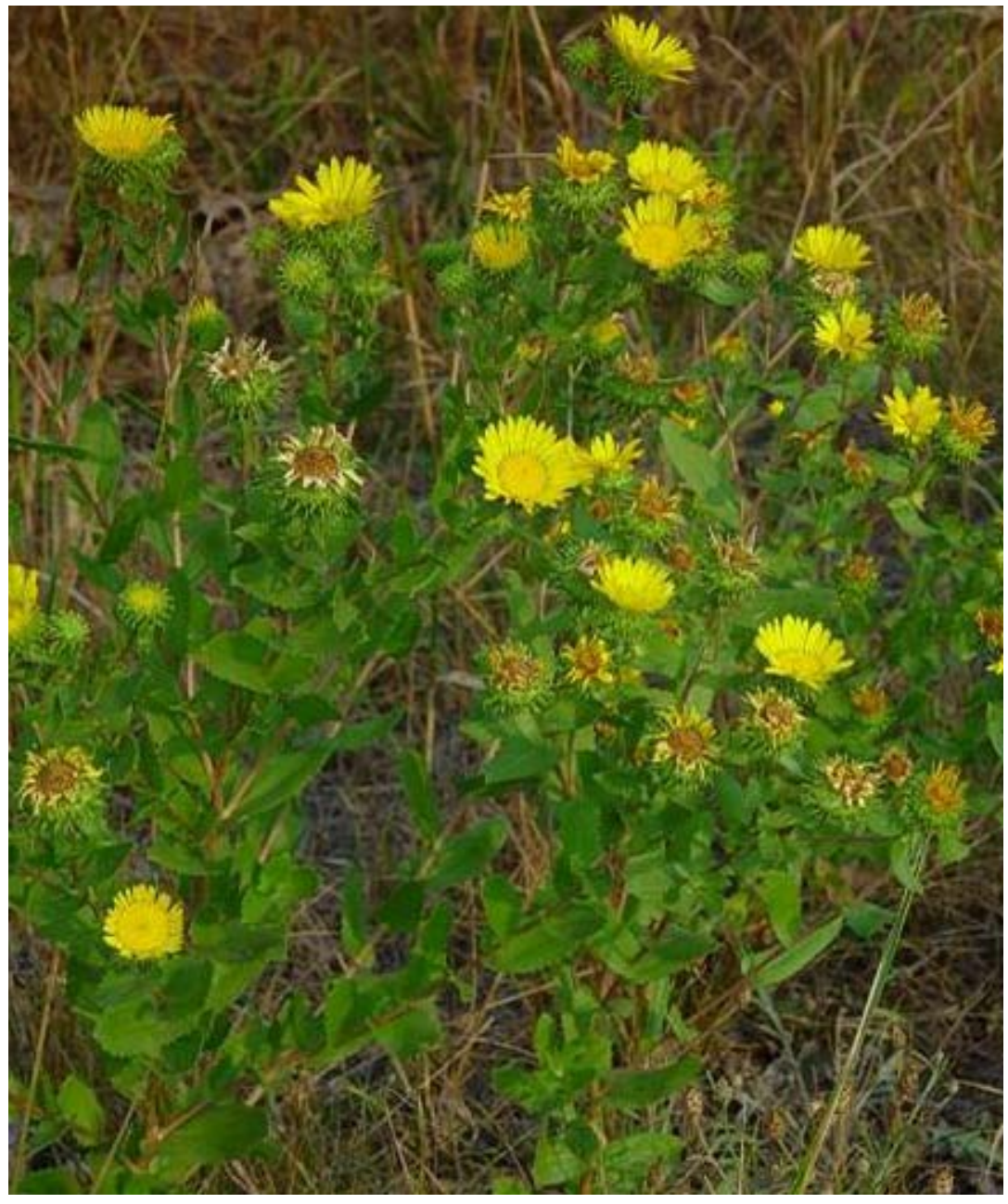

Dan Tenaglia, www.missouriplants.com 
Hordeum jubatum (Foxtail barley)

- Short-lived native perennial

- Grows in dense bunches

Stems

- 2-6 dm long

- Usually upright, but sometimes bent at base

- Densely tufted

Leaves

- Sheathes may be smooth or hairy

- Sheathes are loose and shorter than internodes

- Collar region has membranous ligules and no auricles (in contrast to hare barley)

- Leaves are erect, rough and narrow

- Gray-green in color

- $13-30 \mathrm{~cm}$ long, less than $5 \mathrm{~mm}$ wide Inflorescence

- Heads or spikes are 3-10 cm long

- May be pale green or yellow with a slight red highlight

- Nodding head is distinctive

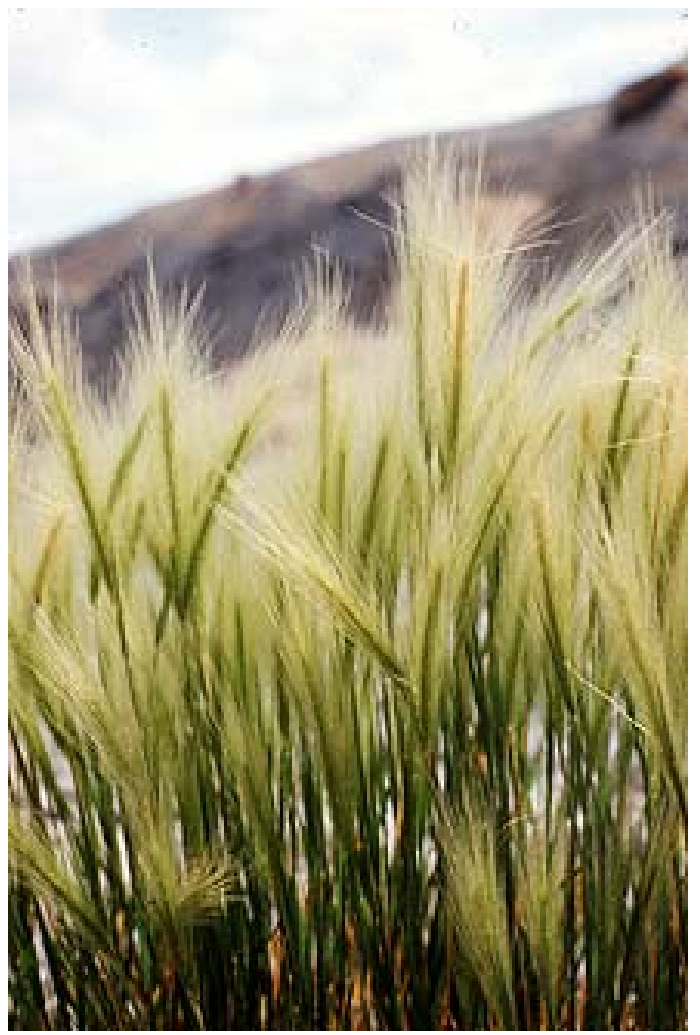

(C) W.L. Wagner

USDA-NRCS PLANTS Database

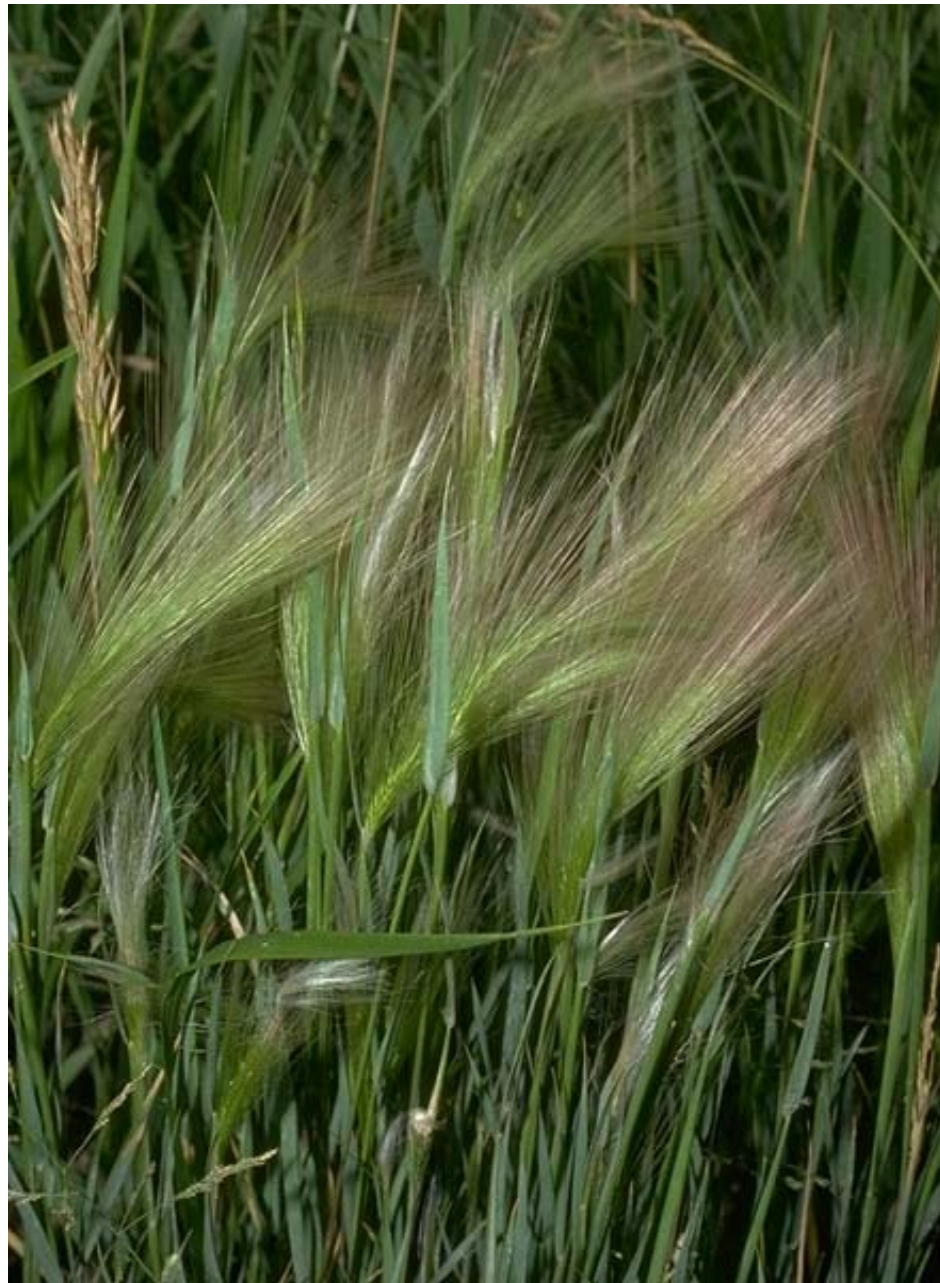

(C) 1999 California Academy of Sciences

Gladys Lucille Smith, photographer

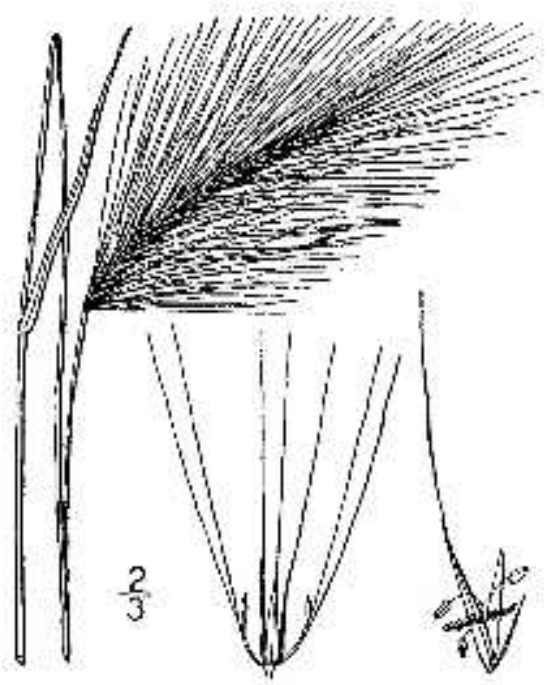

1913 Britton, N.L., and A. Brown USDA-NRCS PLANTS Database 
Hordeum murinum (Hare barley)

- Not native, annual

Stems

- 1-11 dm long

- Branched, spreading or nearly prostrate Leaves

- Papery ligules and characteristic long, narrow auricles clasping the stem (in contrast to foxtail barley without auricles)

- Leaf blades are 2-13 cm long, 2-5 mm wide Inflorescence

- Flower heads are dense and bristly with conspicuous awns

- Florets break from head in groups of 3

- Each floret is awned with ciliated glumes (Central floret has shorter awns than lateral floret on H. leporinum)



University of California Statewide IPM Program Jack Kelly Clark, photographer

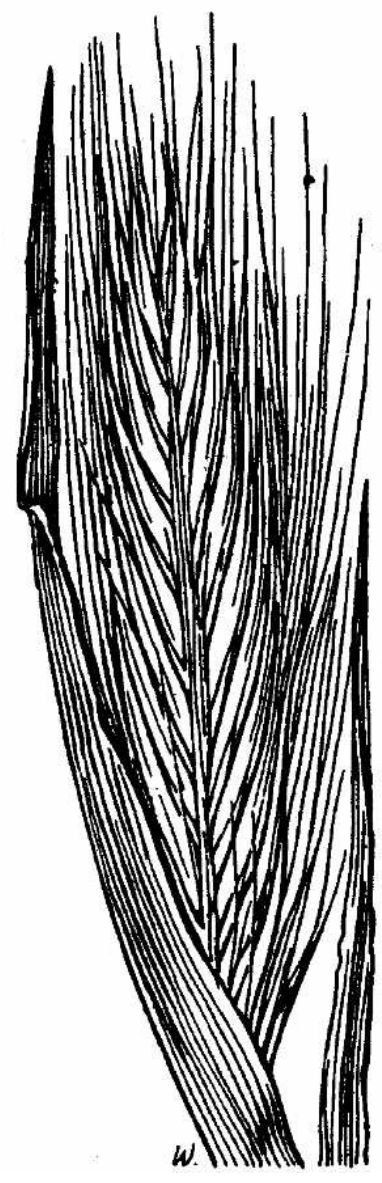

1950 A.S. Hitchcock USDA-NRCS PLANTS Database

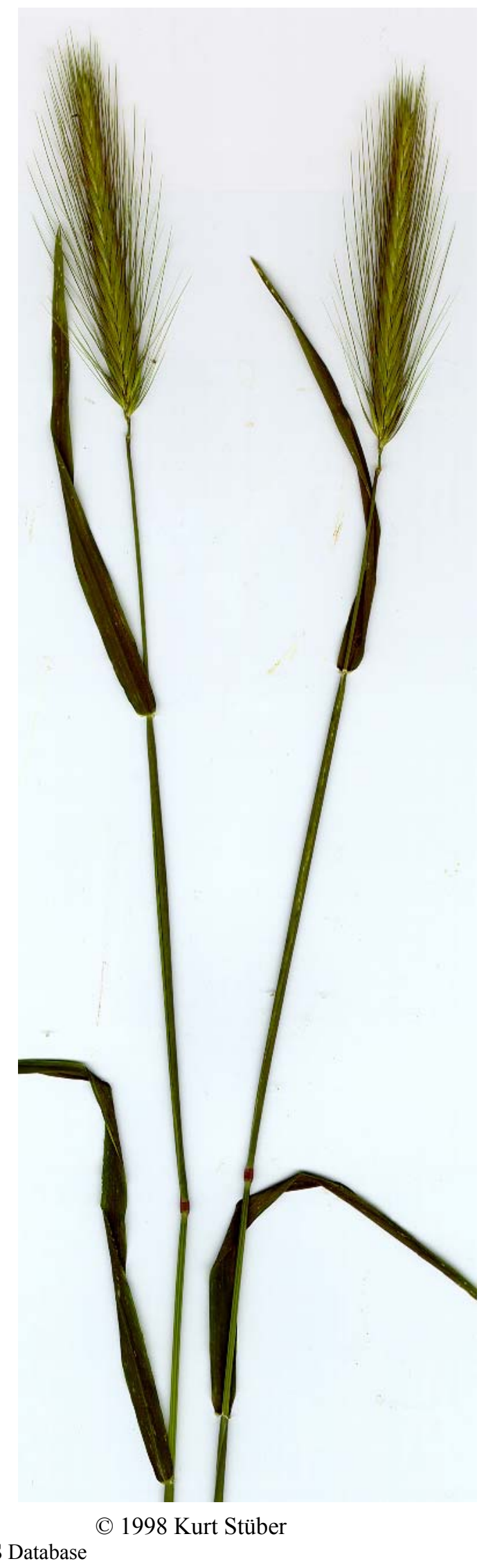


Juncus balticus (Baltic rush)

- Native perennial, rhizomatous

- Grass-like, usually tufted herbs with terete leaves.

Stems

- 1-6 mm wide, generally cylindrical

Leaf Sheaths

- No leaf blades

- Sheaths are clustered at the base, $2-15 \mathrm{~cm}$ long and variable in color

Inflorescence

- Lowest bract of inflorescence is round and 2-20 cm long, bract appear to be a continuation of the stem

- Forms a loose to compact panicle of 10-50 flowers up to $6 \mathrm{~cm}$ long

- Flowers are greenish or brownish (3 sepals, 3 petals, 2 to 6 stamens and a pistil with 3 slender styles)

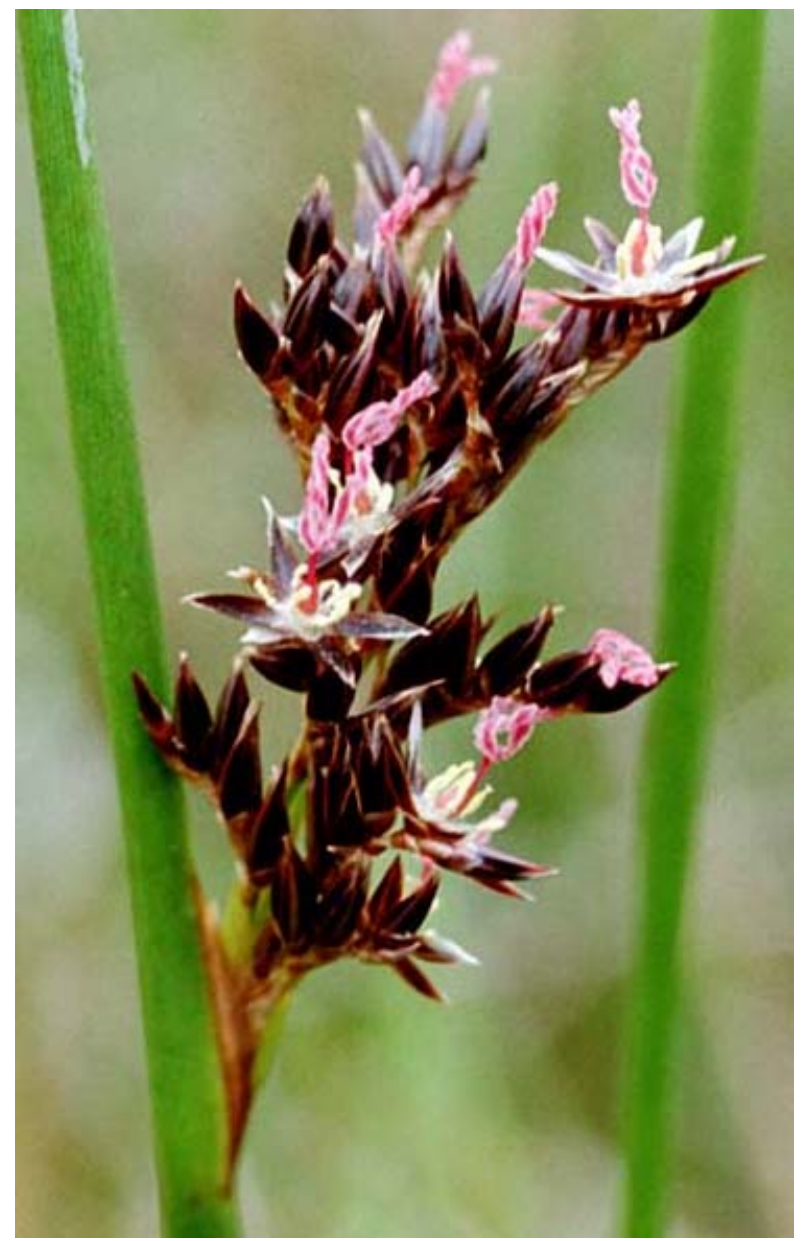

(C) 1998-2003 Chuck Kozak

http://plants.montara.com/
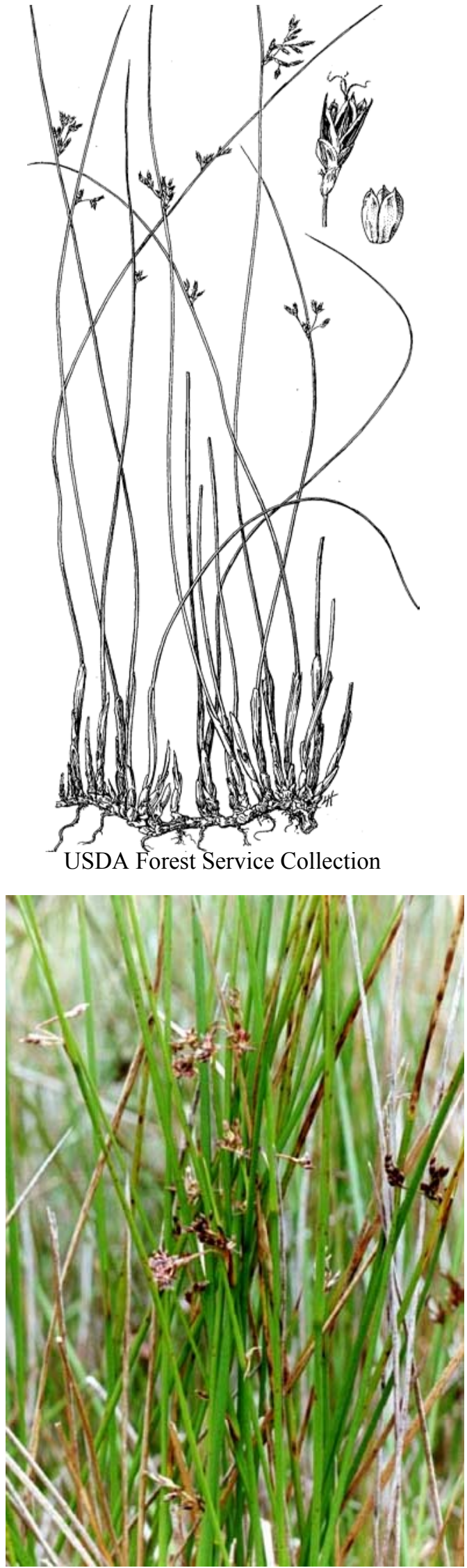

(c) 1998-2003 Chuck Kozak

http://plants.montara.com/ 
Juncus bufonius (Toad rush)

Stems

- Approx $1 \mathrm{~mm}$ wide, branched from base

- $2-30 \mathrm{~cm}$

Leaves

- More or less cauline

- 1-3 per stem, $1 / 2-1 \frac{1}{2} \mathrm{~mm}$ wide

- Sheath margins fused or overlapping, generally with 2 ear-like extensions at blade junction

Inflorescence

- Flowers 1 to few in small clusters

- Lowest bracts leaf-like

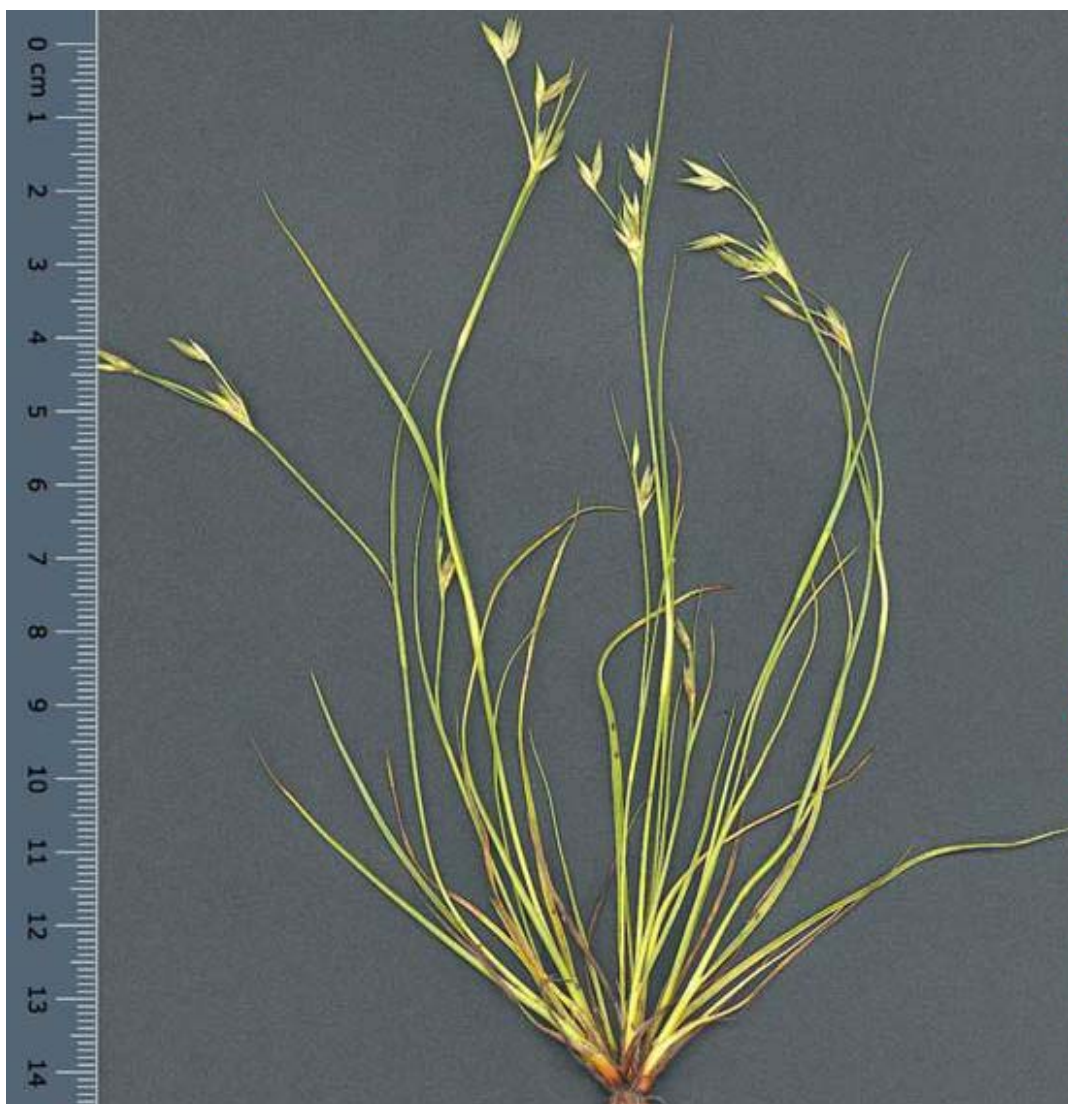

(C) 2000 Herbari Virtual Universitat Illes Balears

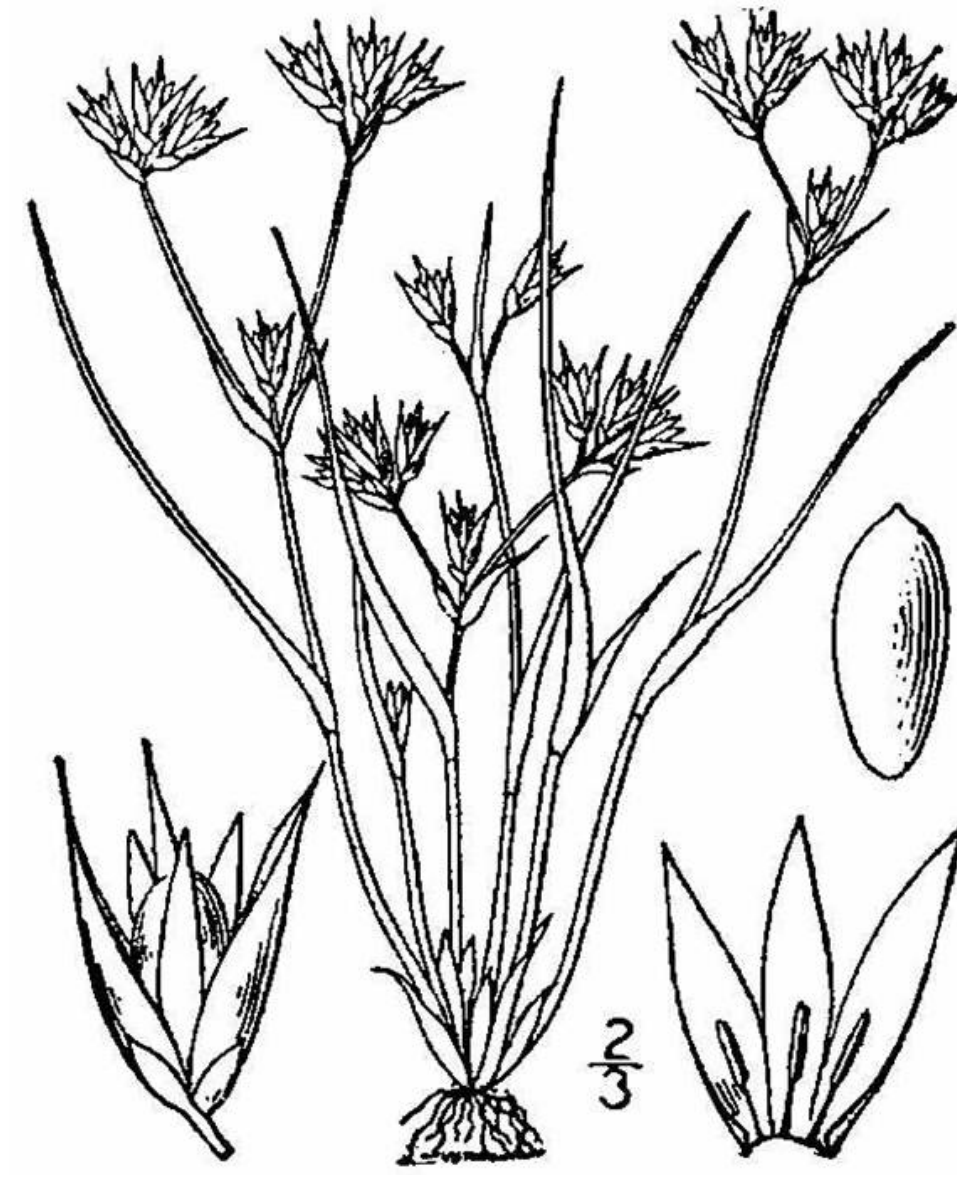

1913 Britton, N.L., and A. Brown USDA-NRCS PLANTS Database

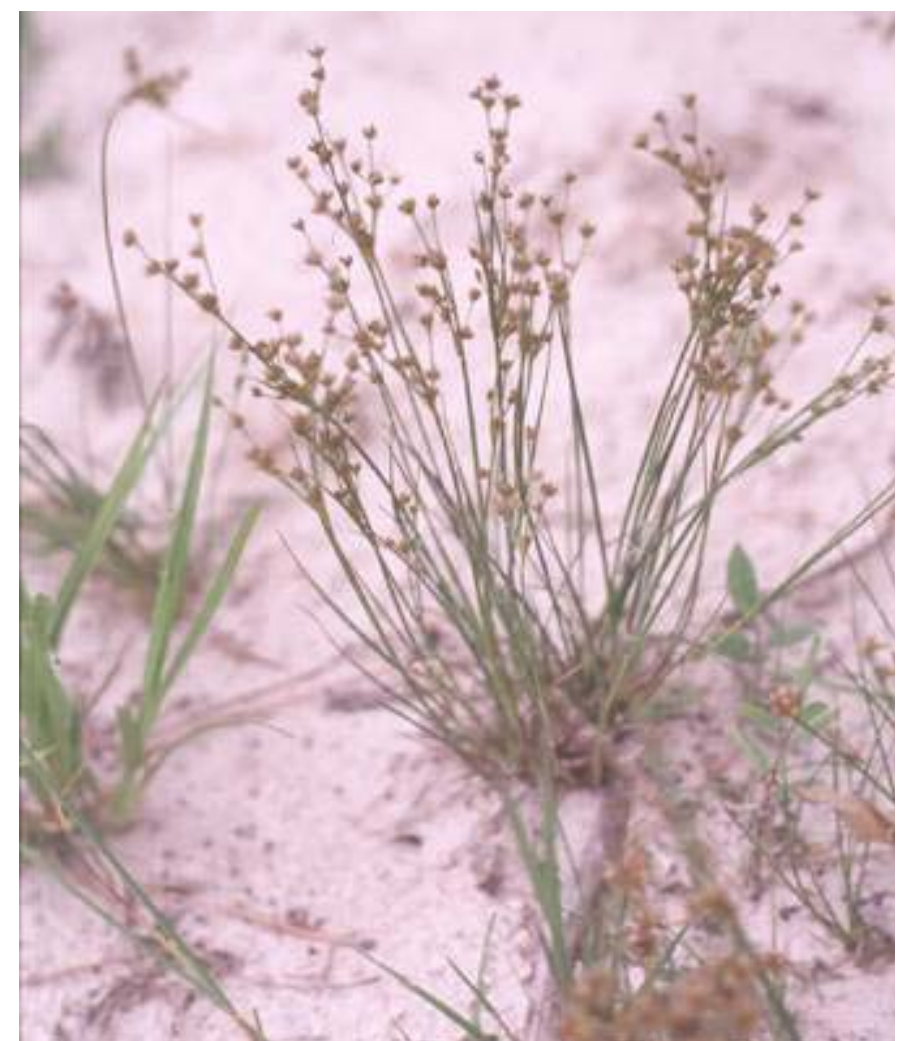

Dr. John A. Haarstad and Barbara C. Delaney University of Minnesota 
Lactuca serriola (Prickly lettuce)

- Not native, annual from taproot, $1 / 2-1 \frac{1}{2} \mathrm{~m}$

Stems

- Erect, prickly-bristly

Leaves

- Basal and cauline

- Alternate

- Dentate to coarsely lobed, prickly on the mid-vein

Inflorescence

- Open panicle with branches often widely spreading

- Heads ligulate

- Flowers 14-20 in number and pale yellow

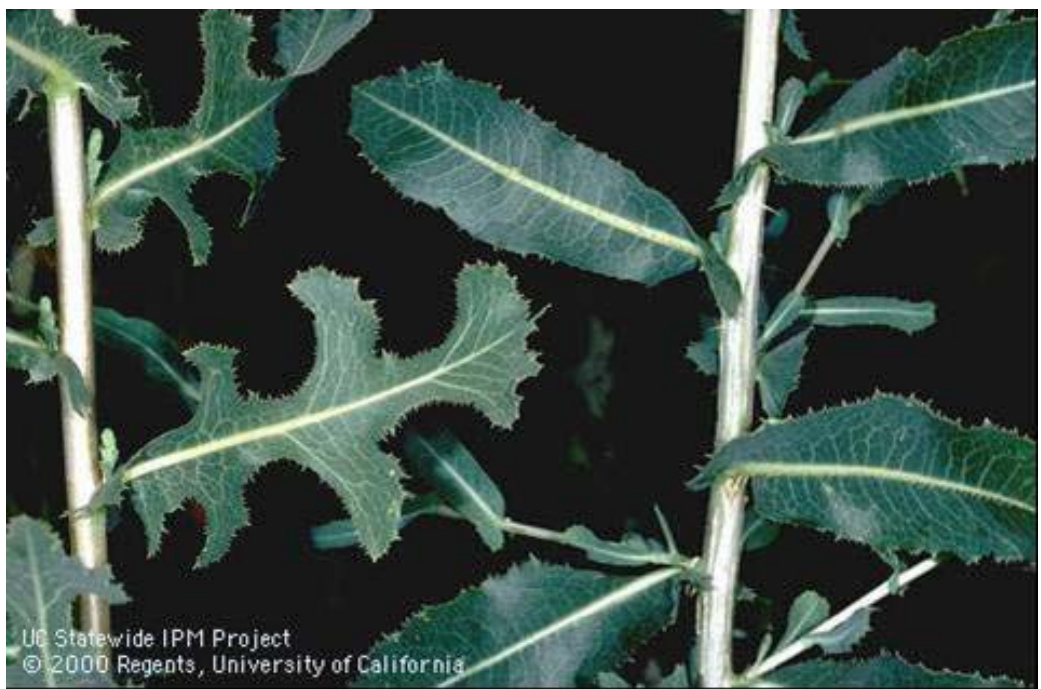

Jack Kelly Clark, photographer

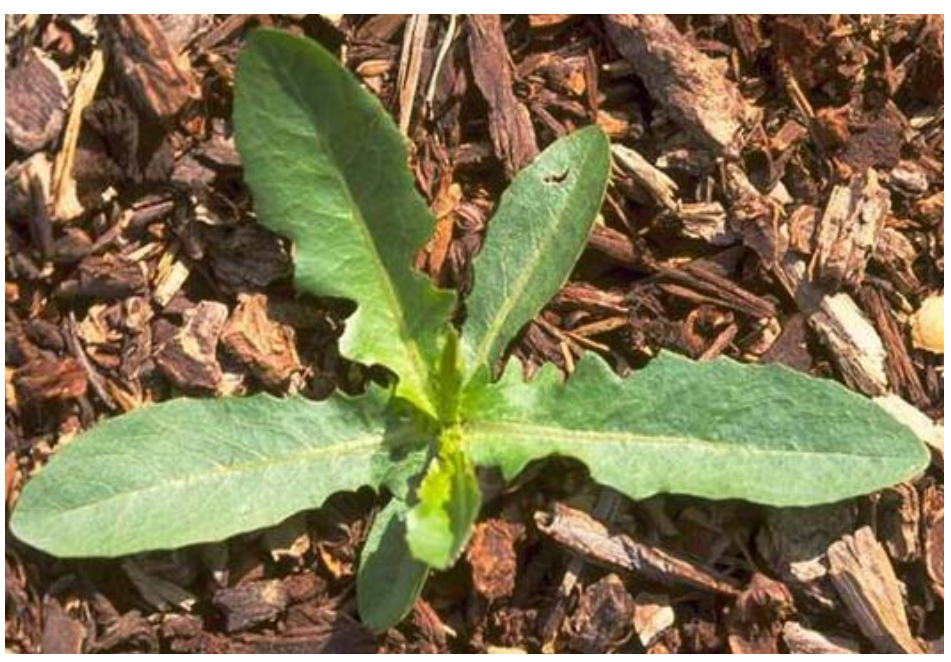

(C) 2000 Oregon State University

Weed Science Program

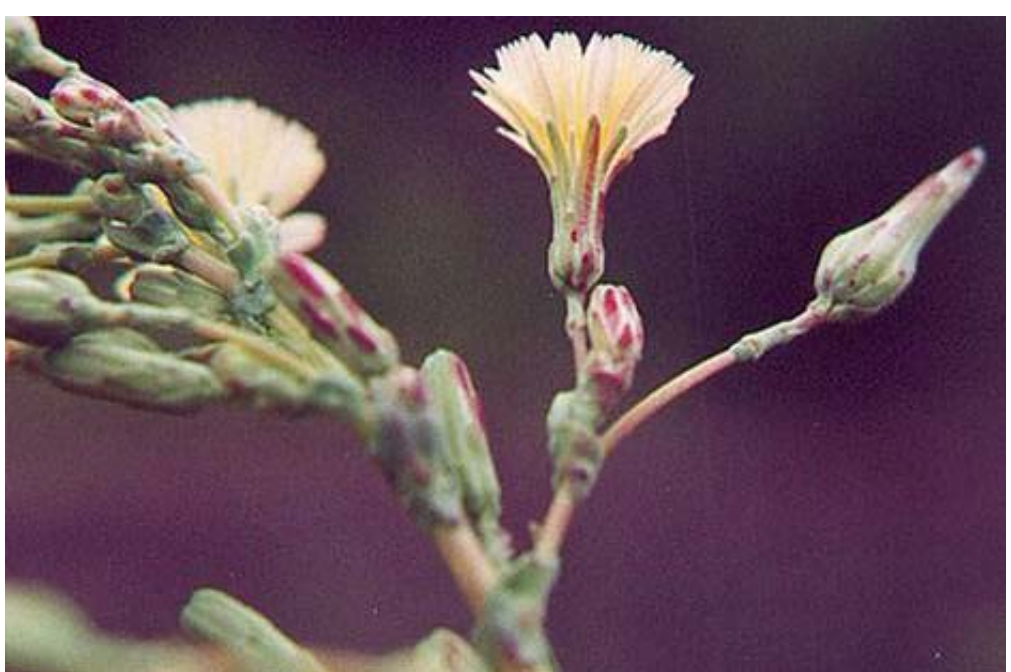

Dan Tenaglia, www.plantatlas.usf.edu

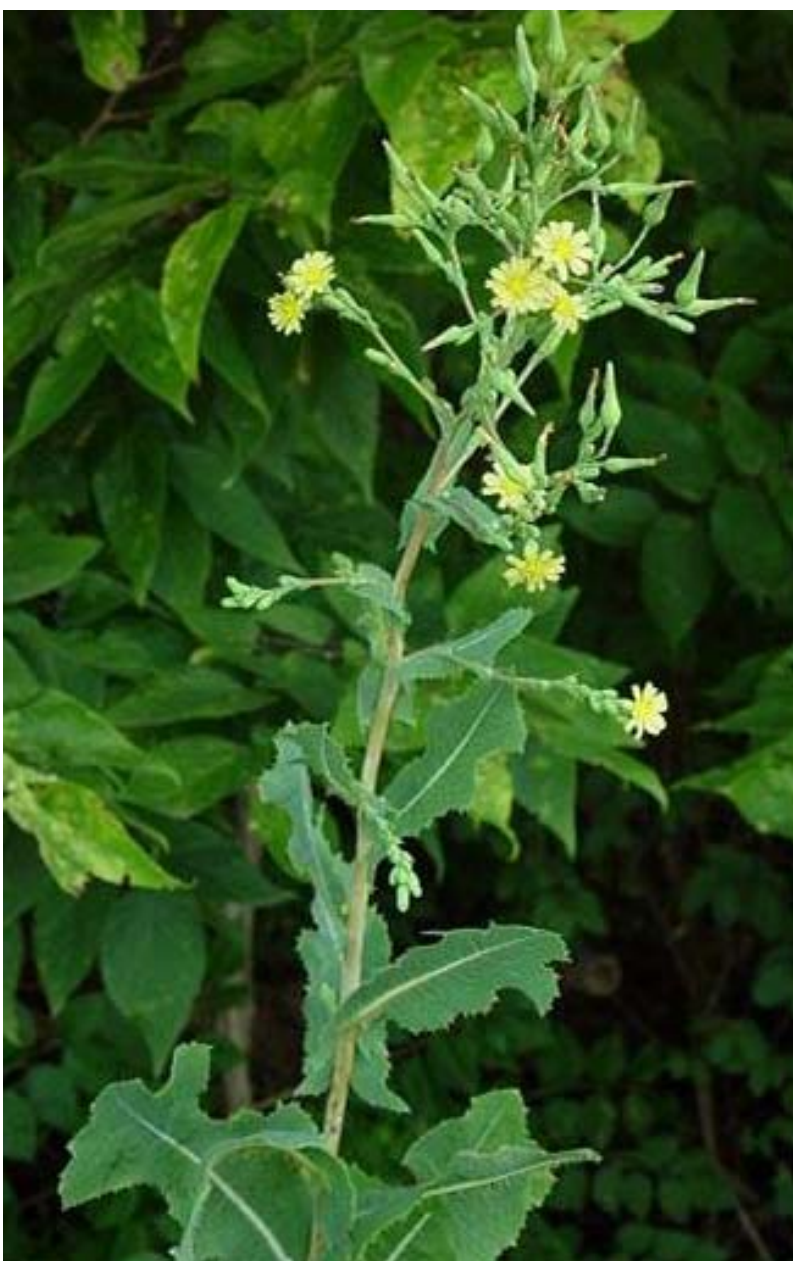

Dan Tenaglia, www.missouriplants.com

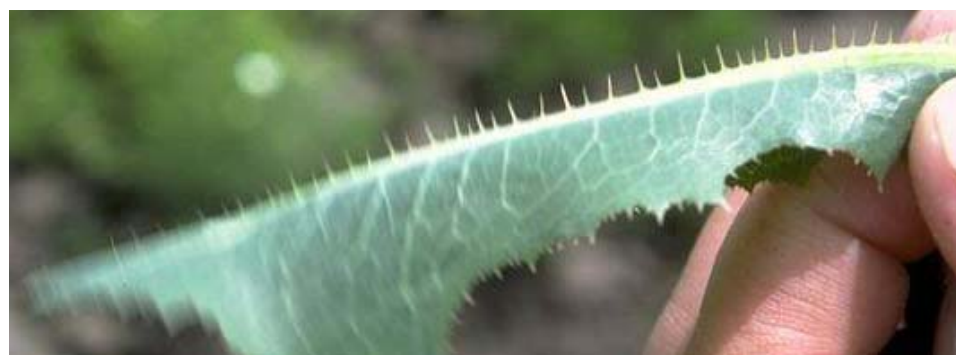

C 2000 Oregon State University

Weed Science Program 


\section{Lasthenia spp. (Goldfields)}

\section{Stems}

- Generally branched and erect

- Less than $60 \mathrm{~cm}$

Leaves

- Opposite

- Less than $20 \mathrm{~cm}$

- Shapes vary among species from entire (without lobes or teeth) to pinnate

Inflorescence

- Heads radiate, solitary or in cymes

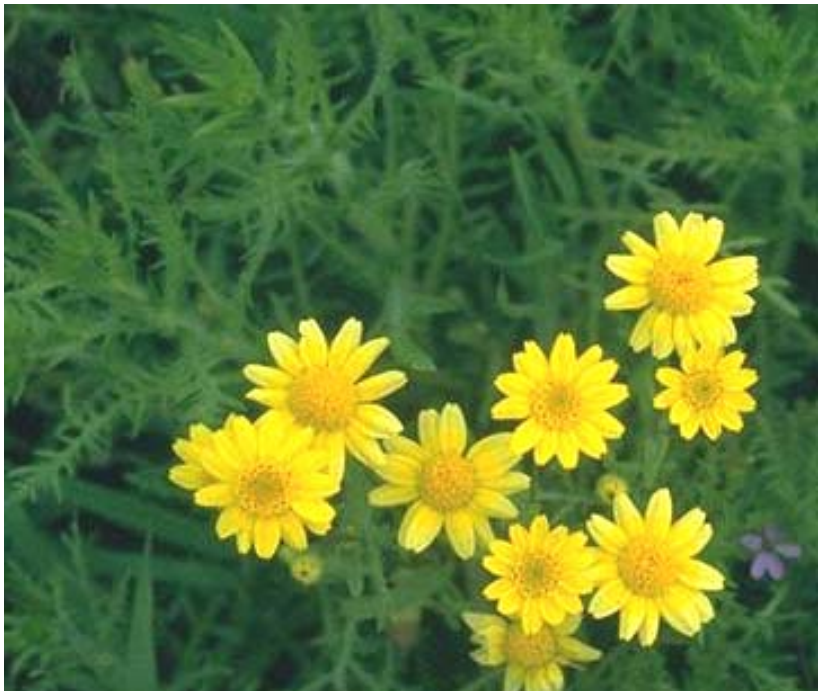

Lasthenia glabrata

(C) 1995 Saint Mary's College of California

Br. Alfred Brousseau, photographer

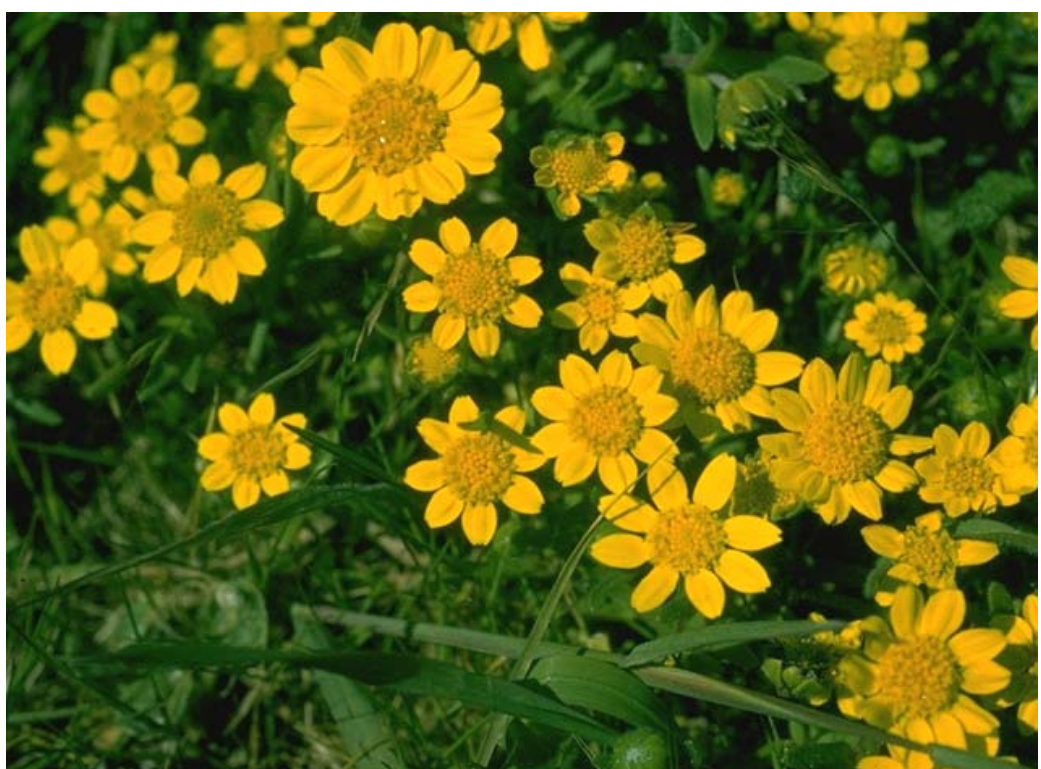

Lasthenia fremontii

(C) 1995 St Mary's College

Br. Alfred Brousseau, photographer

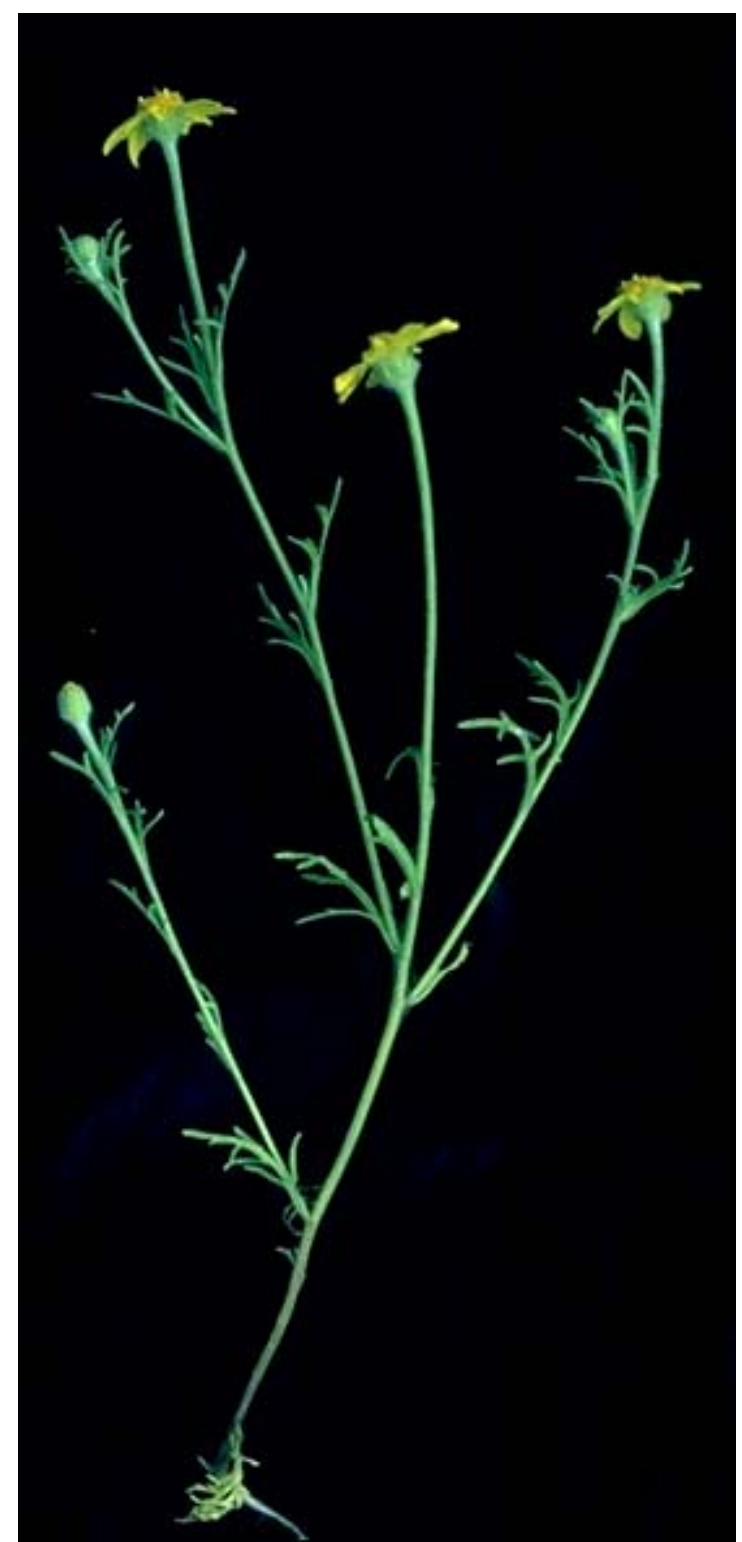

Lasthenia platycarpha

(C) 1995 Saint Mary's College of California

$\mathrm{Br}$. Alfred Brousseau, photographer 
Leptochloa fascicularis (Sprangletop)

- Native annual

Stems

- Spreading to erect

- 3-10 dm long

Leaves

- Seedlings and mature plants have auricles and long, thin, membranous ligules that tear easily

- Mature plants have rough sheaths and leaf blades

- Lower sheaths may be straw colored to reddish

Inflorescence

- Flowering heads are branched and change from dark green when young to straw colored at maturity

- Distinguished from other sprangletops in CA by short awns on the tip of each flower

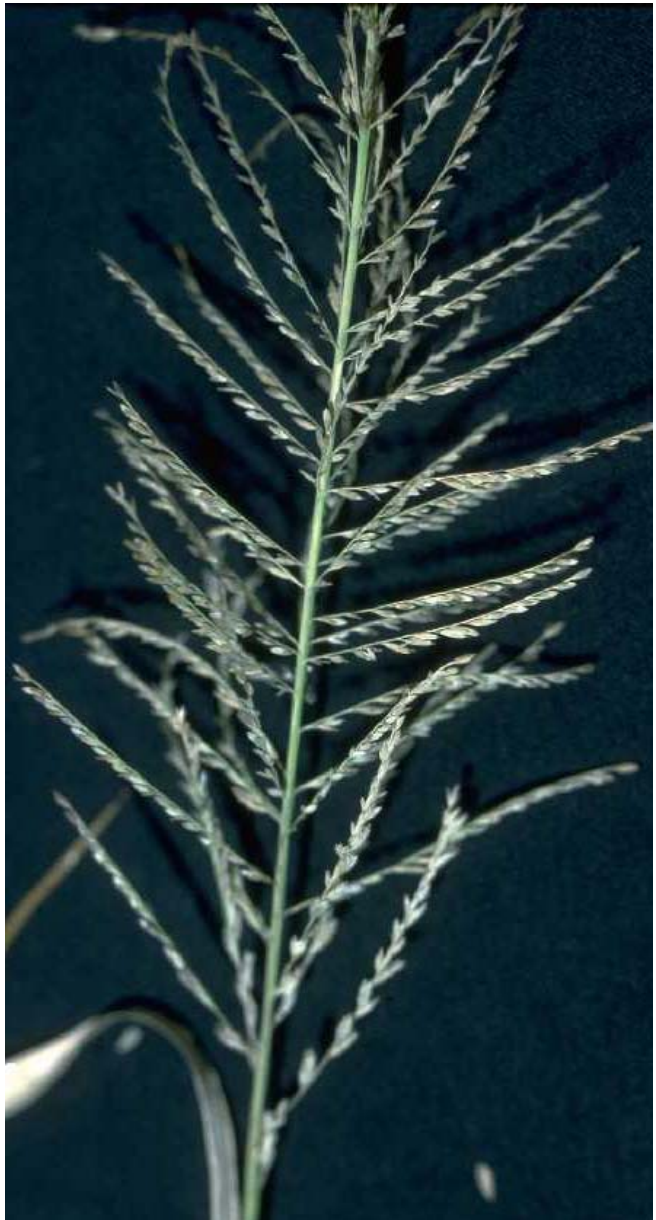

Robert H. Mohlenbrock

USDA-NRCS PLANTS Database

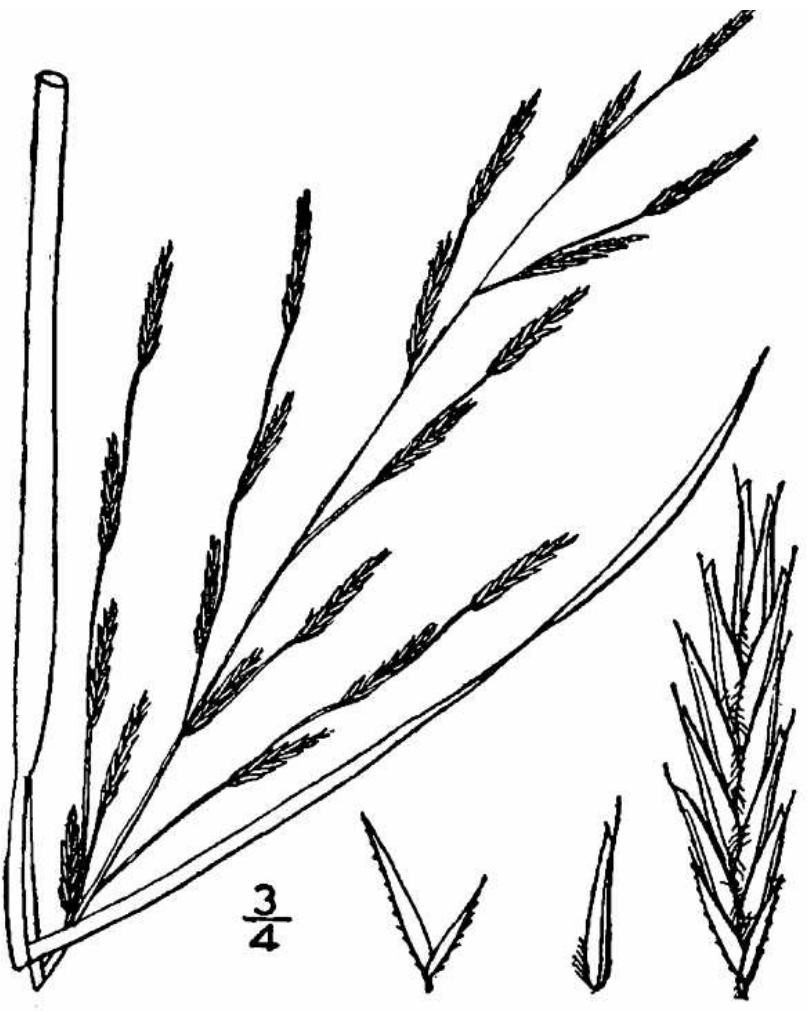

1913 Britton, N.L., and A. Brown USDA-NRCS PLANTS Database
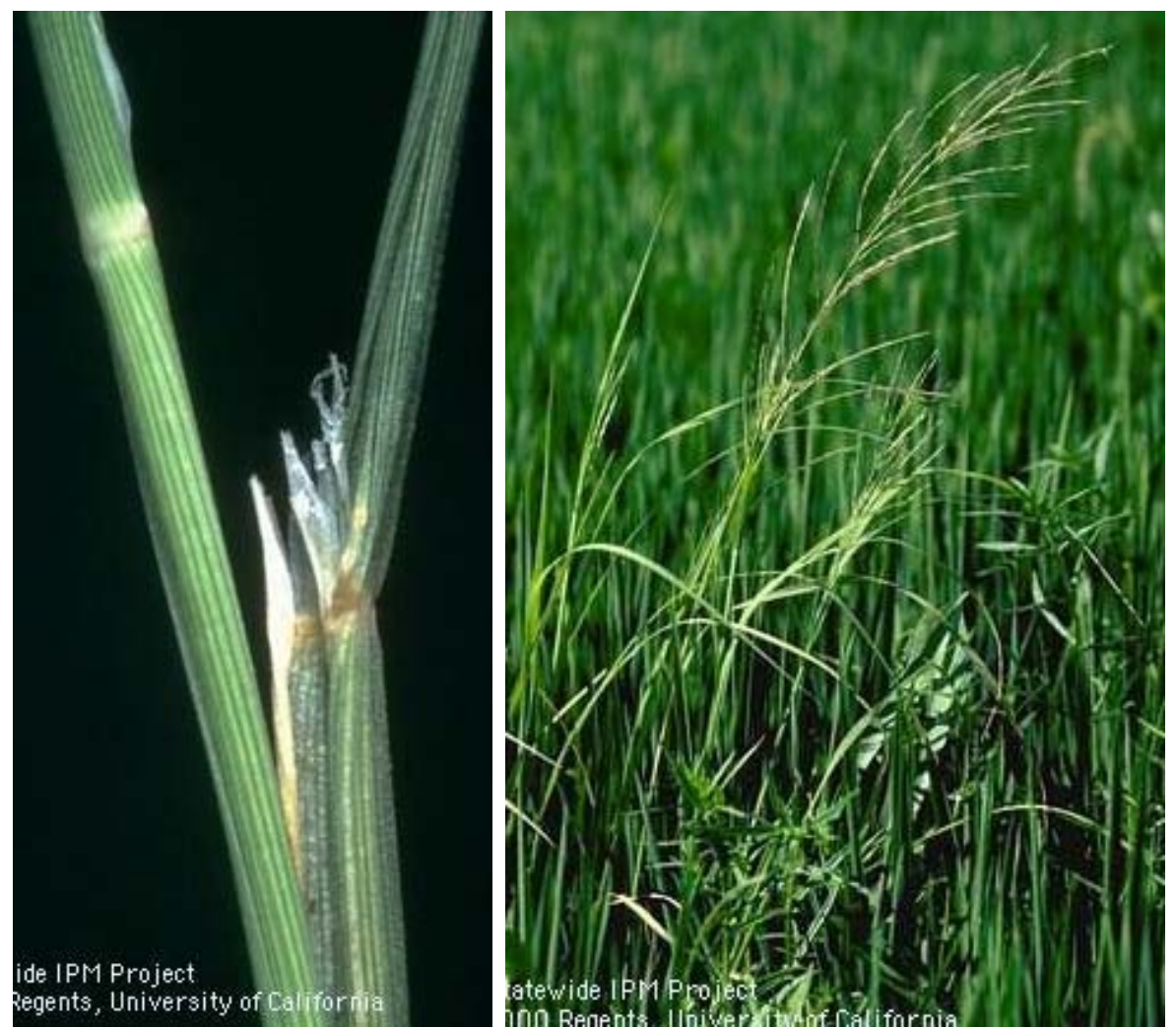

(C) 2000 Regents, University of California UC Statewide IPM Program

Jack Kelly Clark, photographer 
Leymus triticoides (Creeping wildrye)

- Native perennial found in moist, often saline soil

Stems

- $41 / 2-13 \mathrm{dm}$, may or may not be hairy

Leaves

- Blue-green color

- Ligule membranous

- Blade flat or rolled, strongly ribbed above

- Lean away from main stem, 45-75 degrees Inflorescence

- 5-20 cm, narrow

- 1-3 spikelets per node

- Often sterile, plant usually reproduces through underground rhizomes

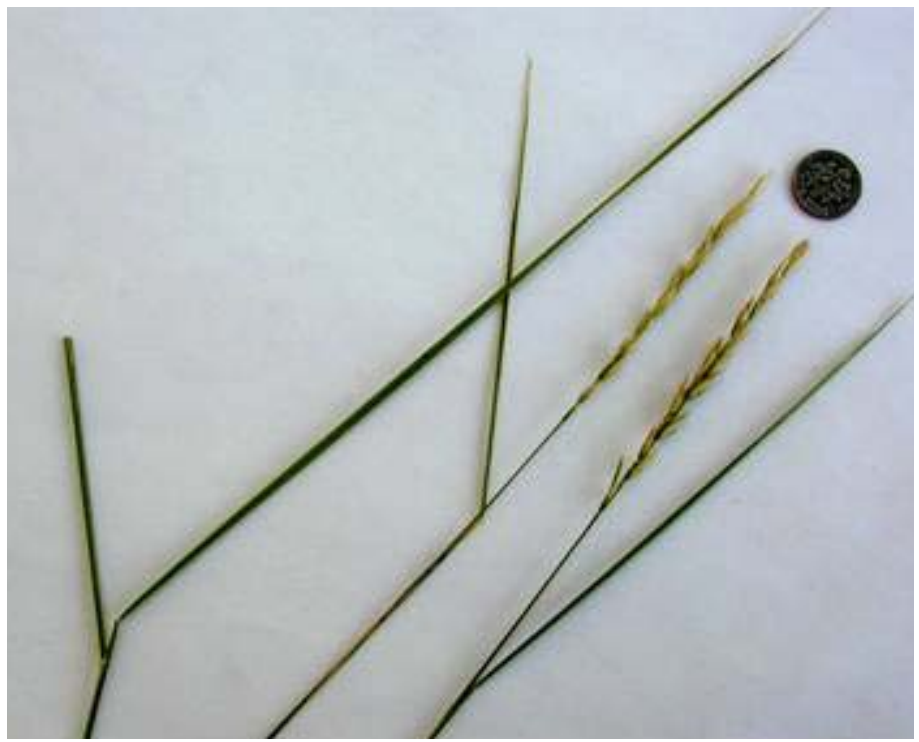

Mark Stromberg and Paul Kephart www.hastingsreserve.org

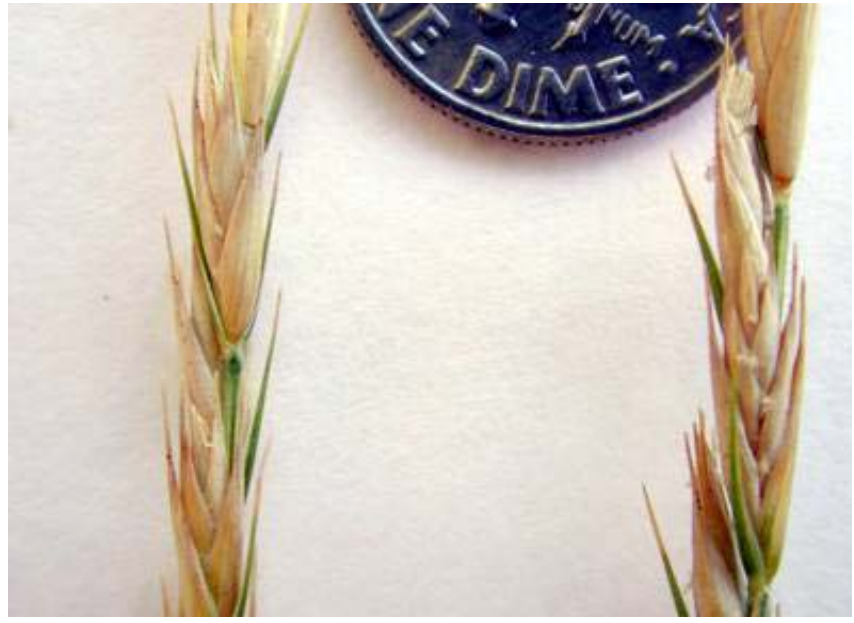

Mark Stromberg and Paul Kephart www.hastingsreserve.org

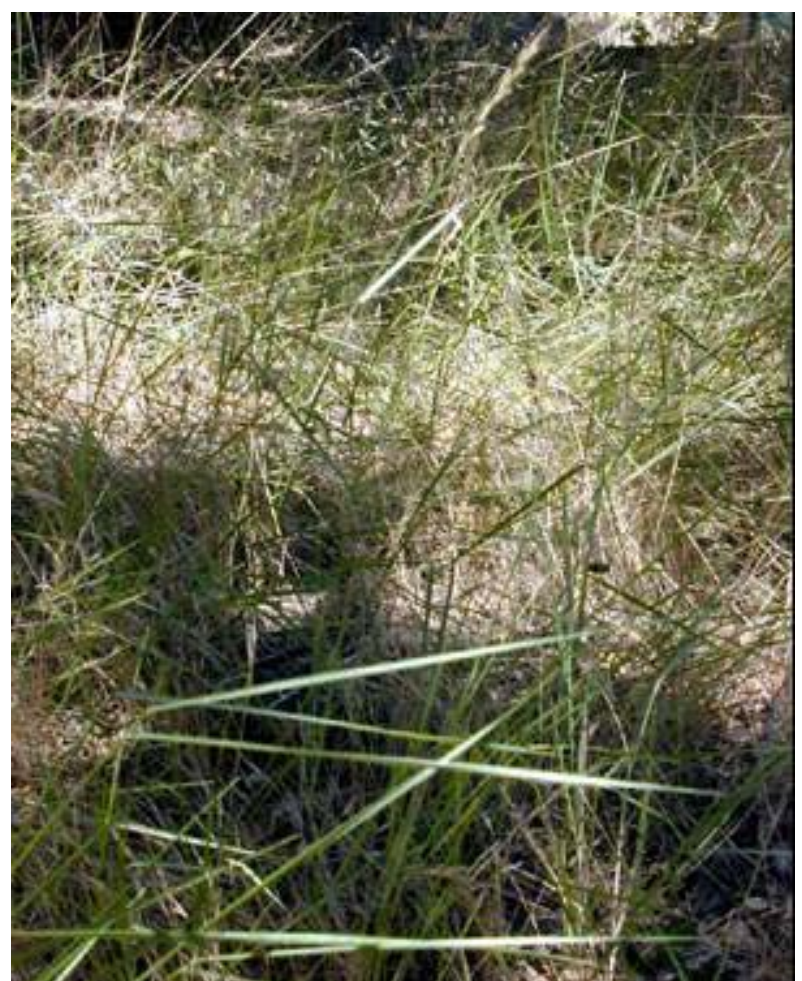

Mark Stromberg and Paul Kephart www.hastingsreserve.org

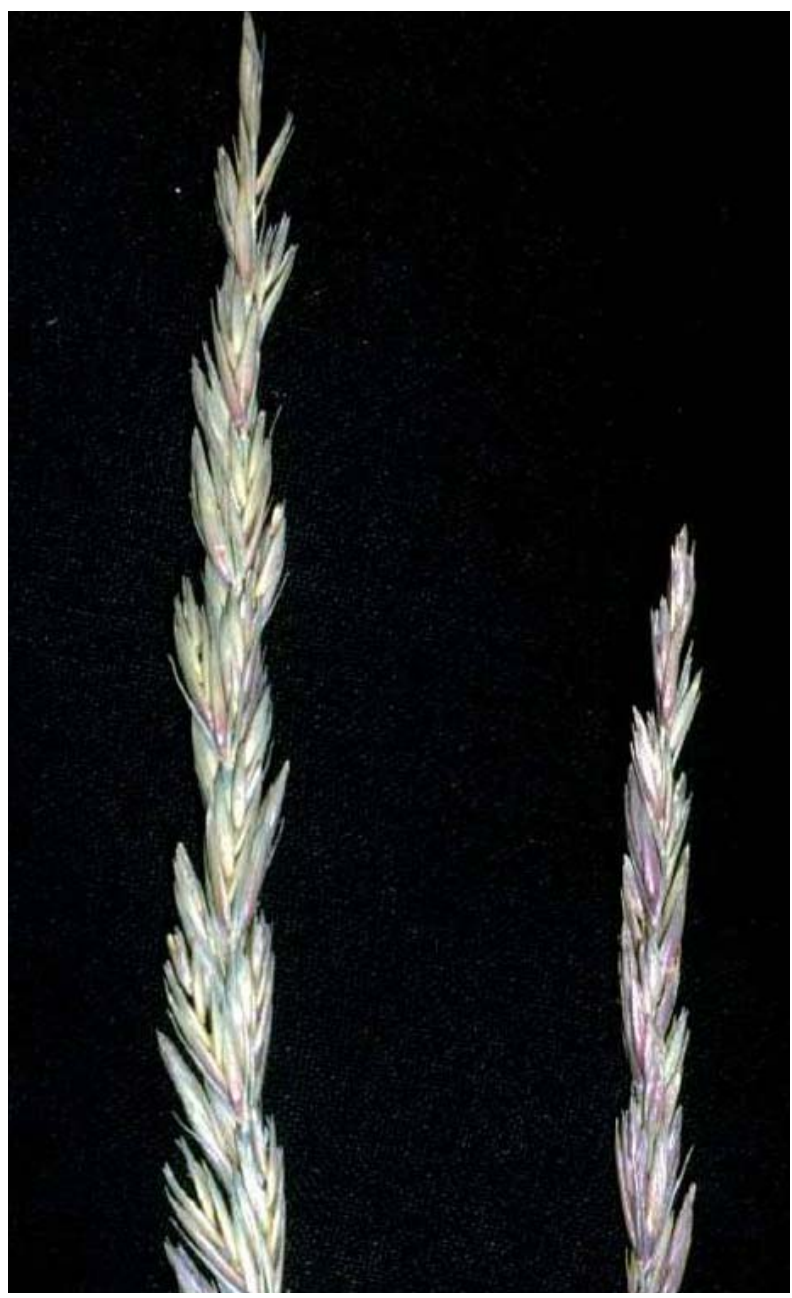

Robert H. Mohlenbrock

USDA-NRCS PLANTS Database 
Lotus corniculatus (Trefoil)

- Not native, perennial

Stems

- Decumbent or ascending Leaves

- Stipule gland-like

- 5 leaflets; 3 palmately arranged at leaf tip, 2 opposite at node

- Linear to egg-shaped

Inflorescence

- Flowers in groups of 3-8

- Sepals 2-31/2 mm

- Corolla 8-14 mm and bright yellow

- Fruit is $1 \frac{1}{2}-3 \frac{1}{2} \mathrm{~cm}$ and narrowly oblong

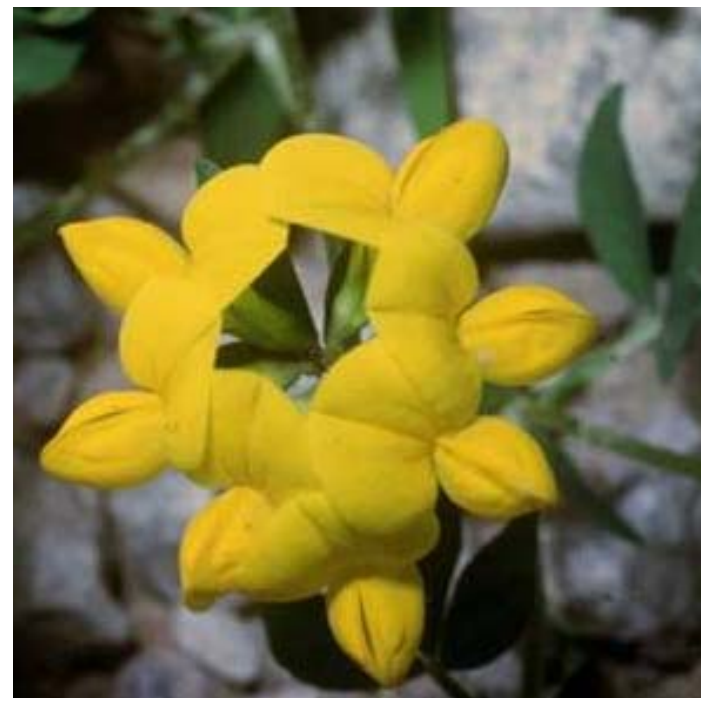

Robert H. Mohlenbrock USDA-NRCS PLANTS Database

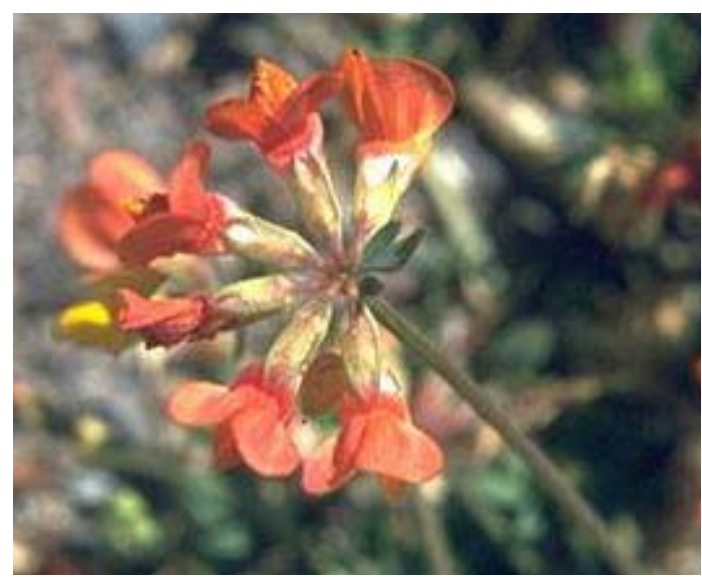

(C) 1995 Saint Mary's College of CA Br. Alfred Brousseau, photographer

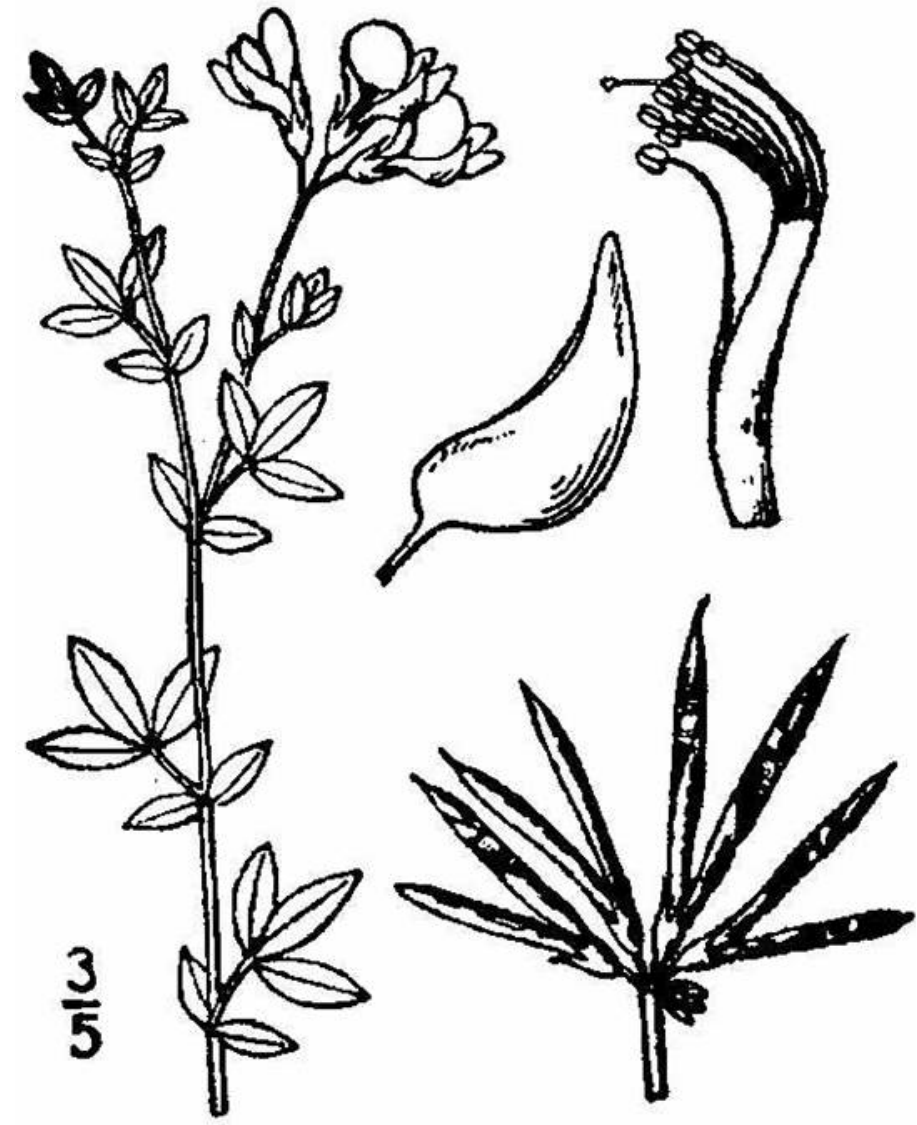

1913 Britton, N.L., and A. Brown USDA-NRCS PLANTS Database

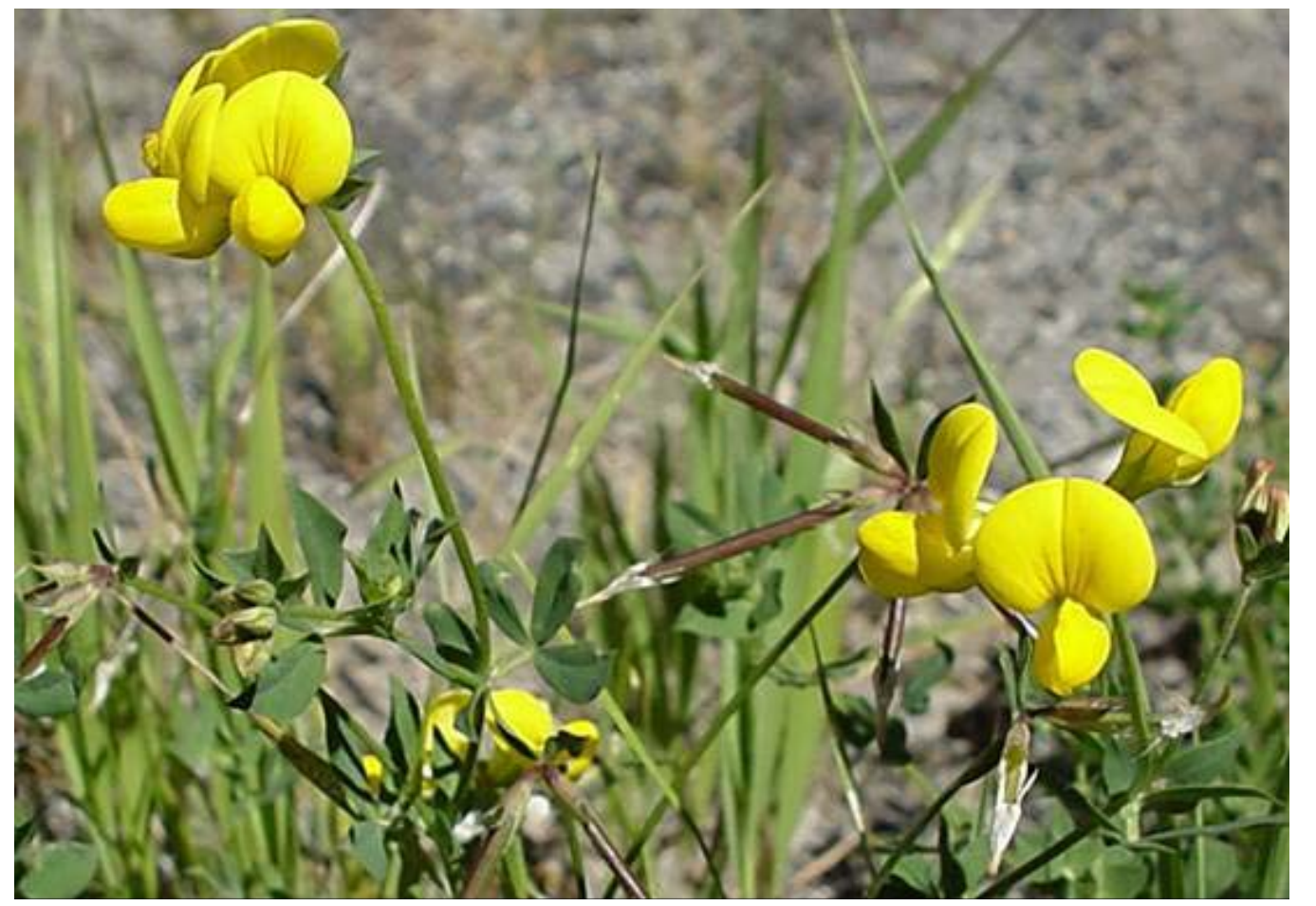

(C) 2001 Jeff Abbas 


\section{Malva spp.}

- Not native, annual or biennial

\section{Malva neglecta}

- Stems decumbent and 2-6 dm long

- Generally densely stellate-hairy

- Leaf blade 2-6 cm wide without lobes or with 5-7 obscure lobes

- Rounded teeth around edges

- 5 petals 8-13 mm, pale pink, lilac or white

- Corolla subtended by 5 acuminate sepals and 3 broadly linear bracts

\section{Malva parviflora}

- Stems erect and 2-8 dm long

- Stellate-hairy near stem tips, smooth below

- Leaf blade 2-8 $\mathrm{cm}$ wide with 5-7 lobes

- Rounded teeth around edges

- 2-4 flowers per axil, crowded

- Flowers with 5 petals, $4-5 \mathrm{~mm}$, white to pink

- Corolla subtended by 5 egg-shaped sepals and linear bracts

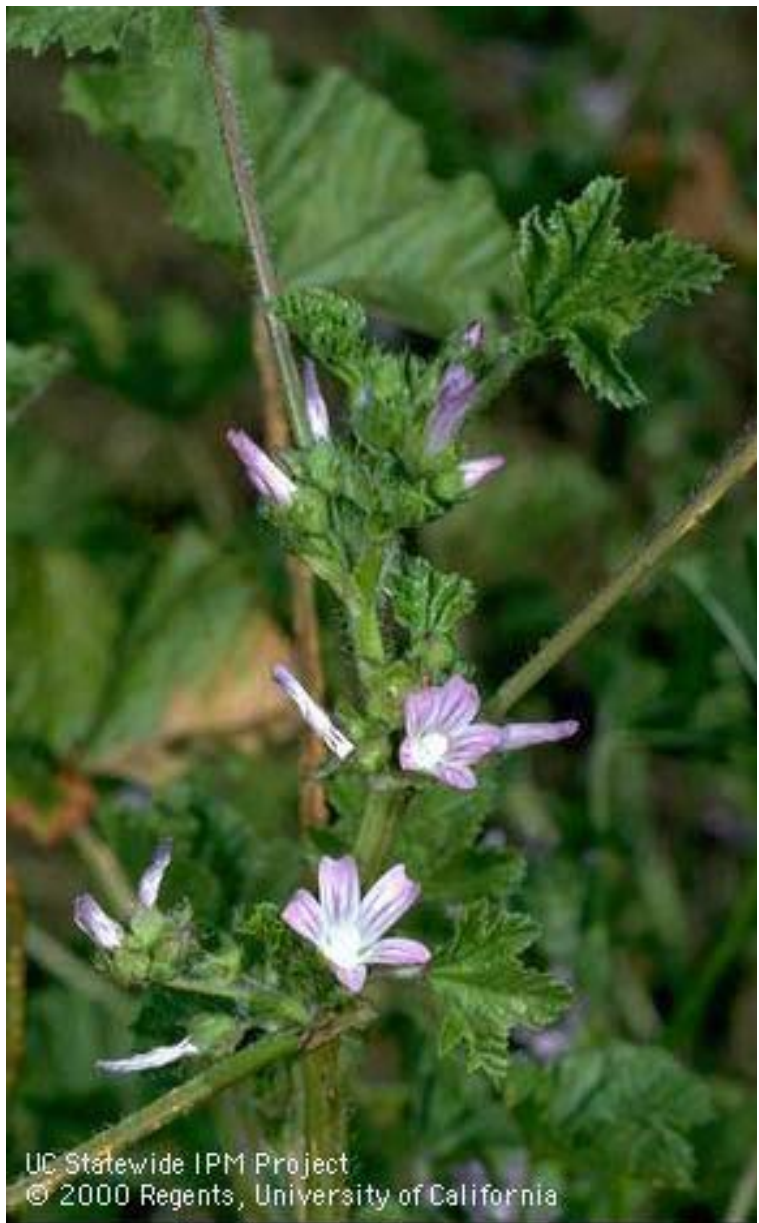

Malva parviflora

Jack Kelly Clark, photographer

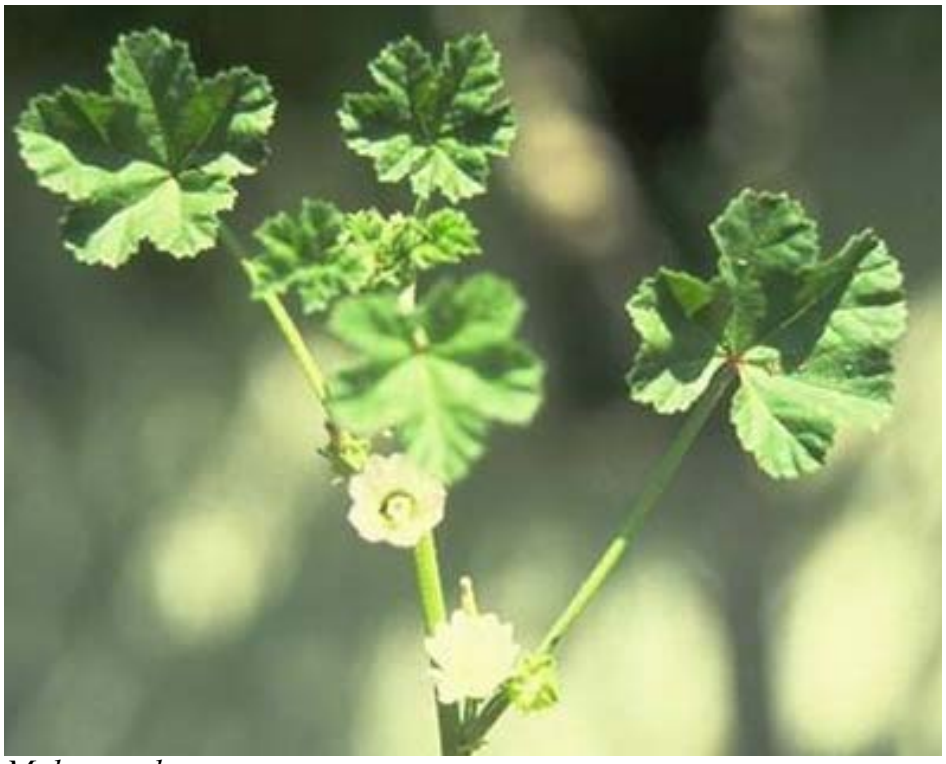

Malva neglecta

(C) 2000 Oregon State University

Weed Science Program

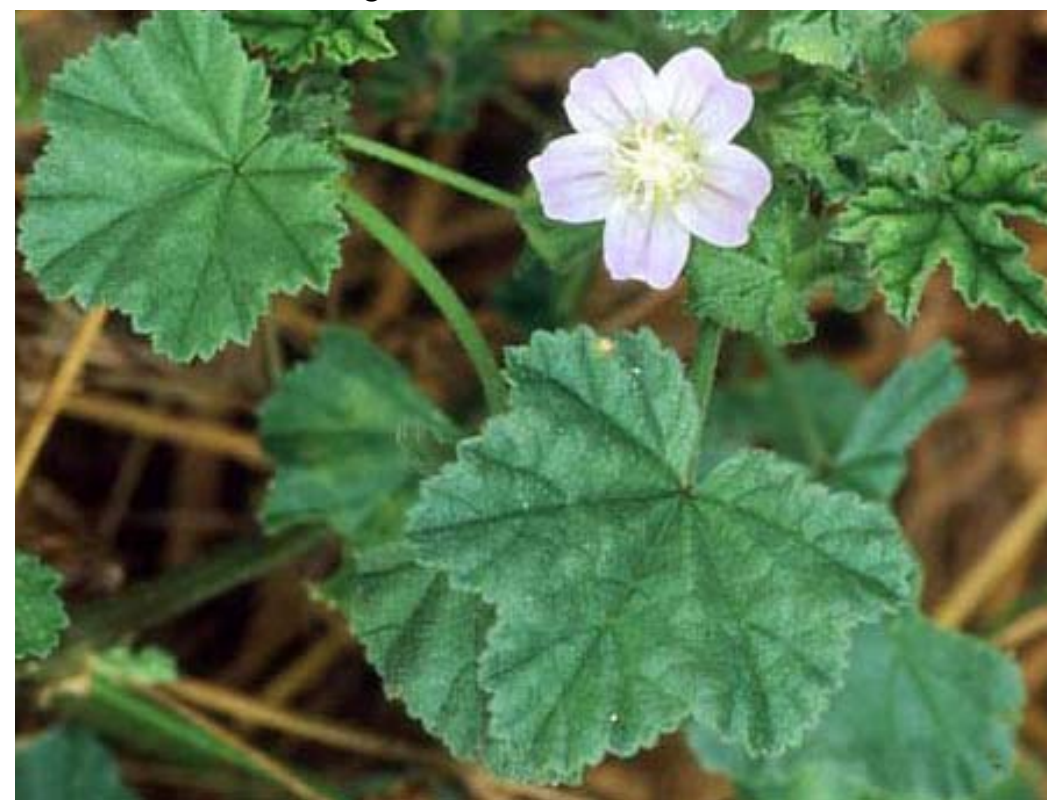

Malva neglecta

Dennis D. Horn, photographer

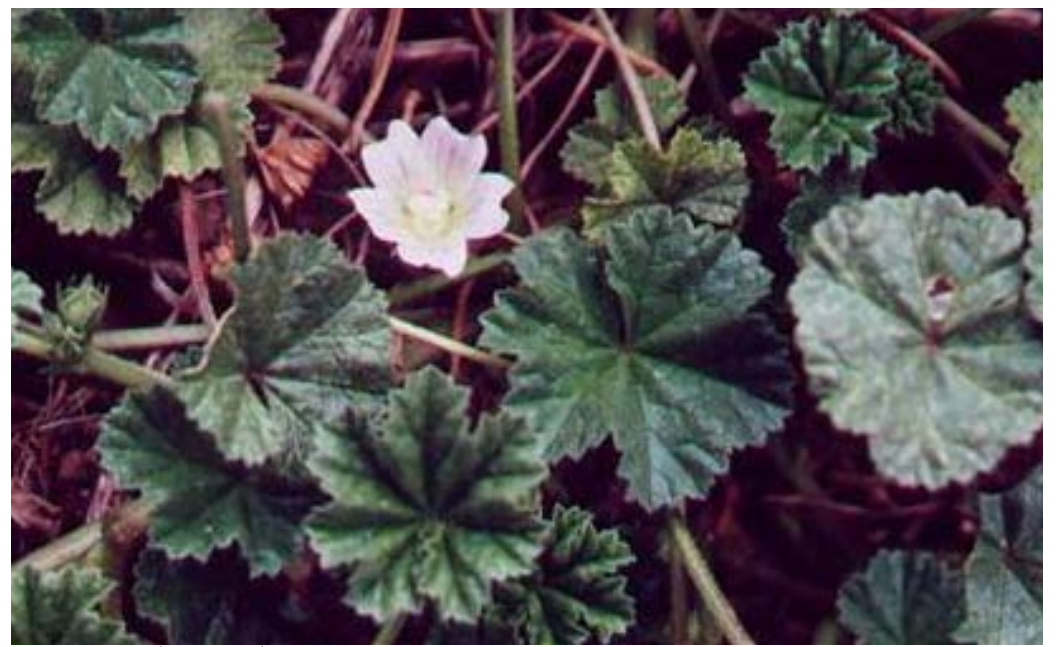

Malva neglecta

Dan Tenaglia, www.missouriplants.com 
Melilotus officinalis (Yellow sweetclover)

- Biennial, not native

Stems

- Generally erect

- $1 / 2-2$ meters tall with spreading branches Leaves

- $\quad$ Odd 1-pinnate, with 3 leaflets

- Leaflet are $1-2 \frac{1}{2} \mathrm{~cm}$, elliptic-oblong to obovate and toothed

Inflorescence

- Small, yellow-flowered clusters at the ends of slender stalks

- Axis 3-8 cm long when flowering

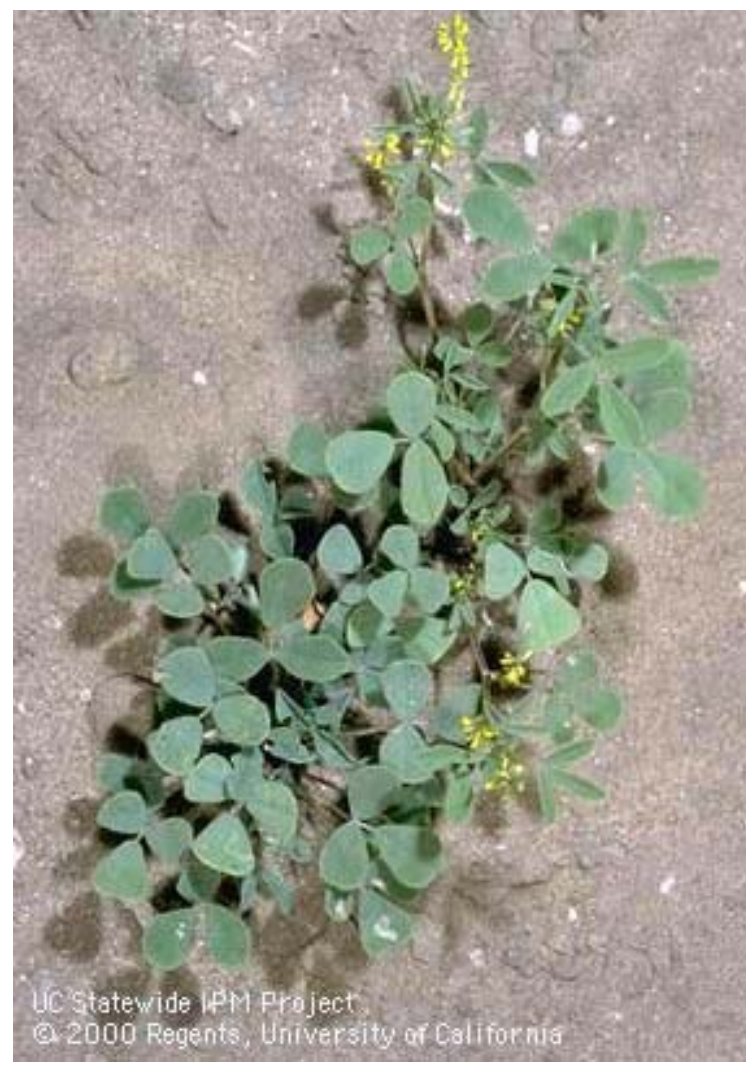

University of California Statewide IPM Program Jack Kelly Clark, photographer

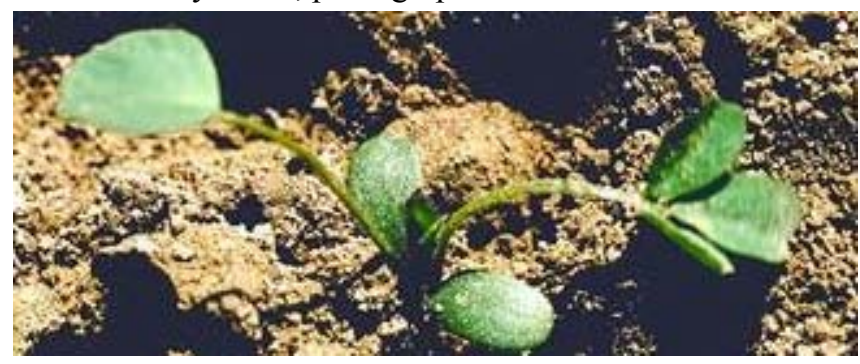

C 2000 Regents, University of California

UC Statewide IPM Program

Jack Kelly Clark, photographer

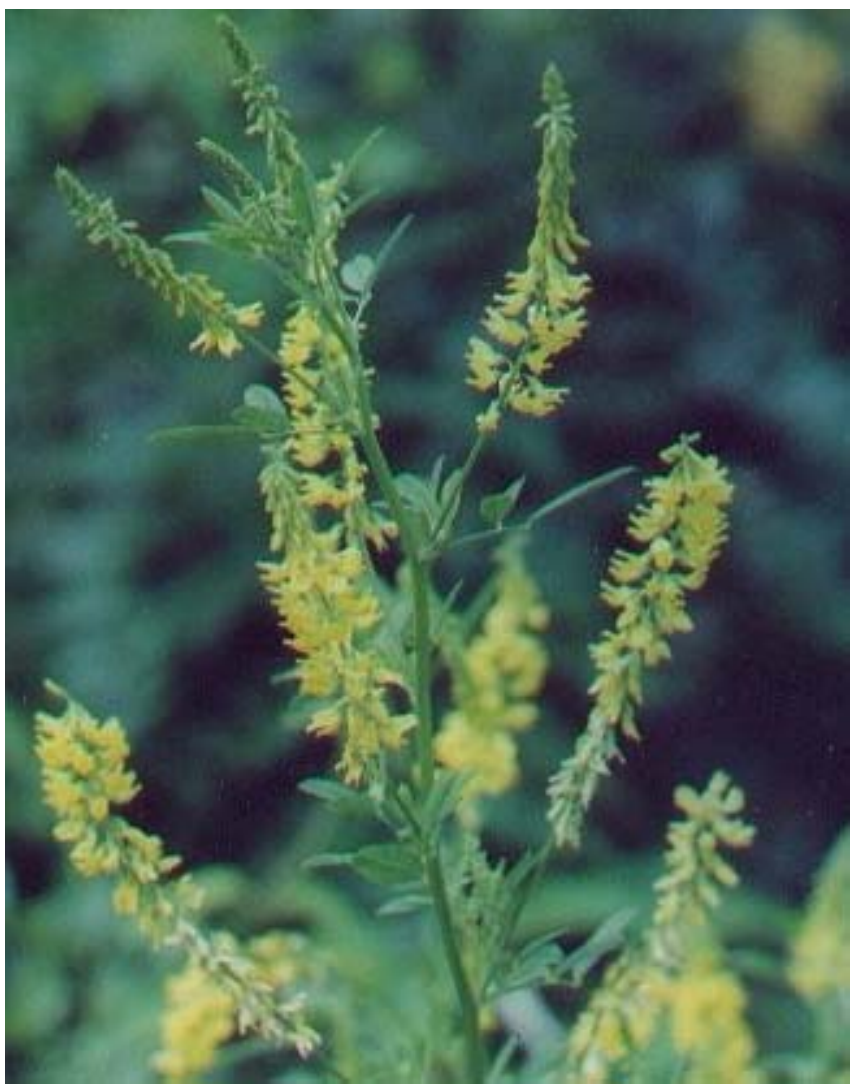

Dan Tenaglia, www.missouriplants.com

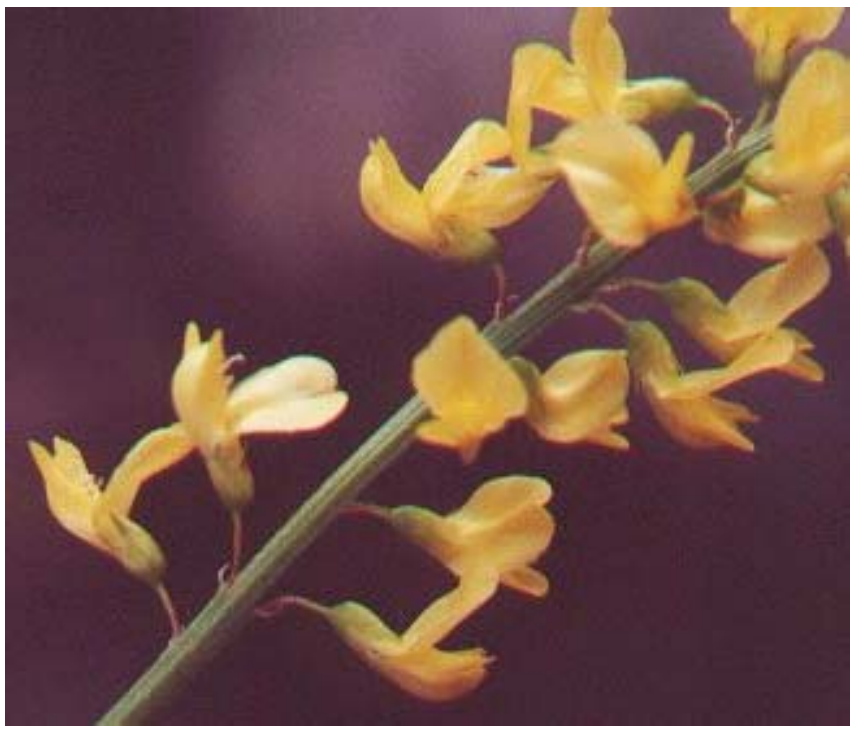

Dan Tenaglia, www.missouriplants.com 
Paspalum distichum (Jointgrass)

- Perennial

- Grows from stolons and rhizomes

Stems

- Decumbent to erect

- 1-6 dm high

- 5-15 nodes

Leaves

- Sheath and blades are hairless

- Blades 2-22 cm long, 2-7 mm wide

- Sheath 3-20 cm

Inflorescence

- 2-3 branches from main axis

- Pale green and elliptical
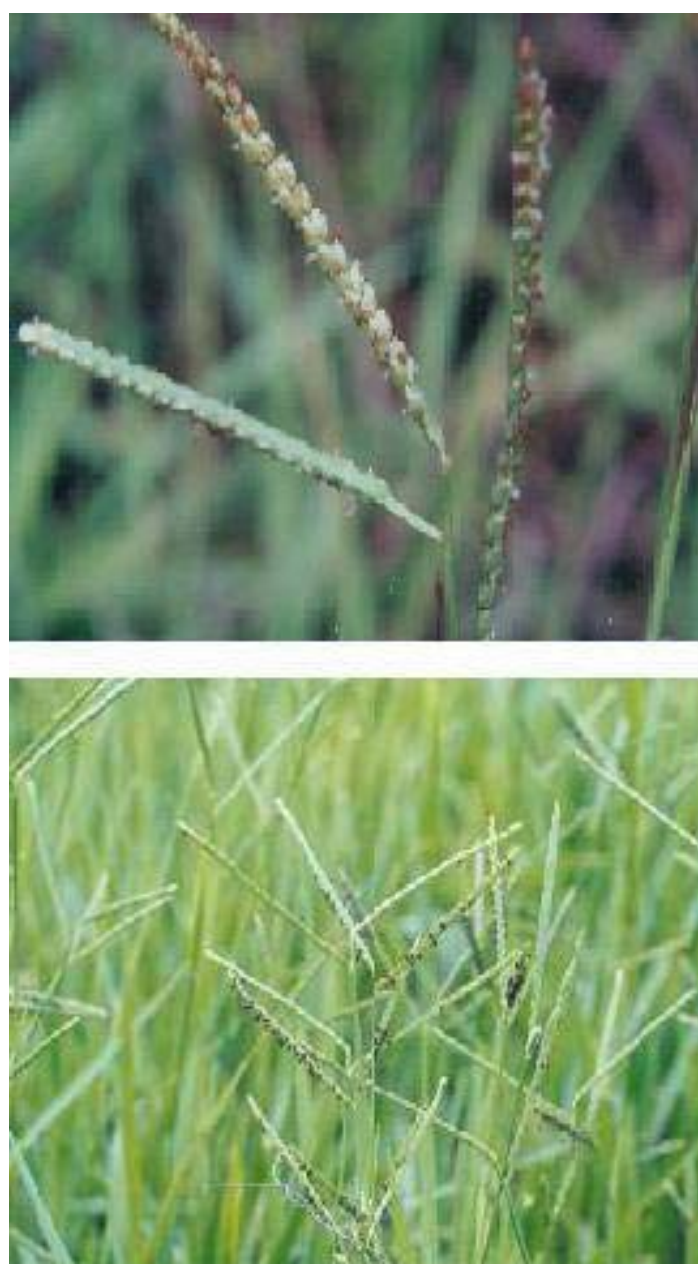

Copyright information unknown

Source: www.dld.go.th

Dept of Livestock Development
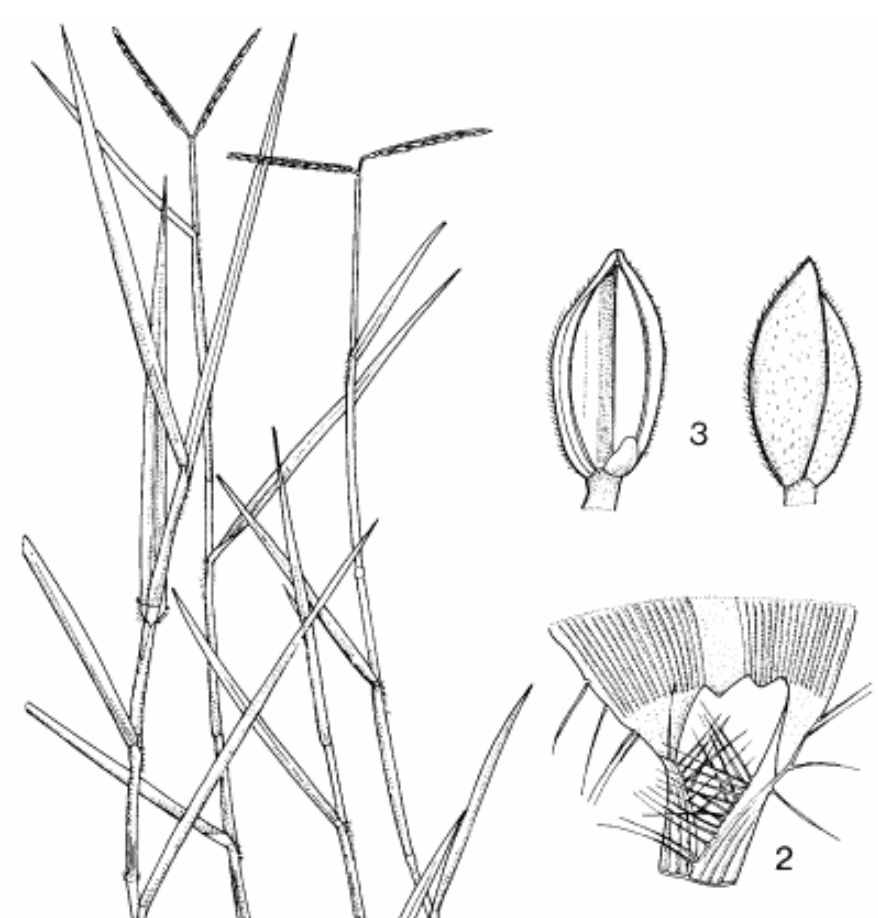

Paspalum distichum L. -- 1, habit flowering plant; 2, ligule; 3 , spikelet in two views.

Copyright information unknown

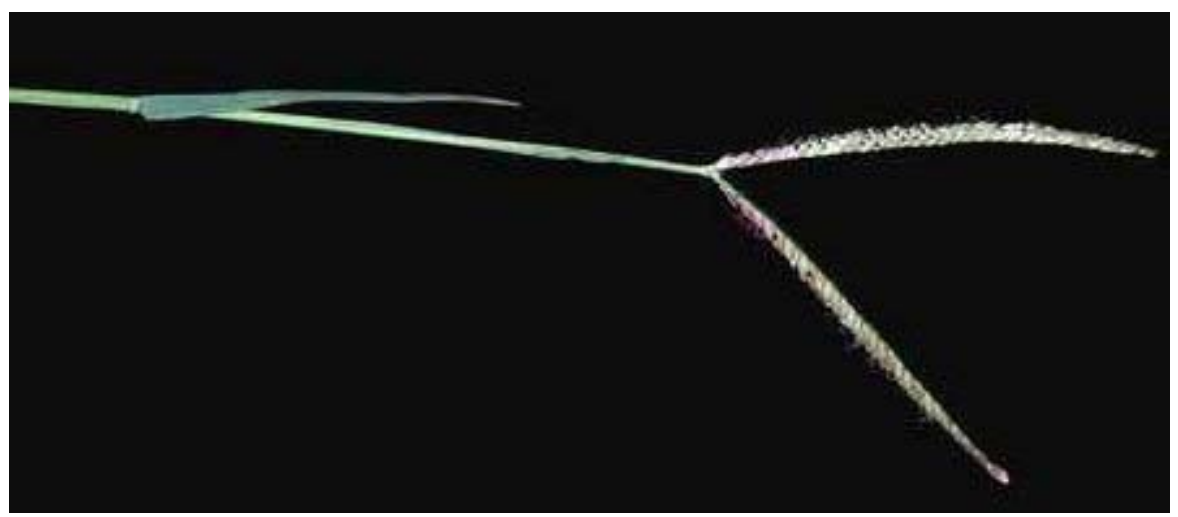

(C) 2000 Regents, University of California

UC Statewide IPM Program

Jack Kelly Clark, photographer 
Phragmites australis (Common Reed)

- Native perennial

- Grows from rhizomes, stolons possible Stems

- 2-4 m tall, stiff, smooth, erect stems are hollow, round, and unbranched

- Can be almost woody, sometimes purplish Leaves

- Blades 25-45 cm long, 1-5 cm wide, taper to a long point, narrow slightly toward the stem

- Broad, stiff and flat with rough margins

- Surface is hairless and ridge-veined above, and hairless or sparsely hairy below

- Sheath is smooth, except for fine hairs along the margins, usually overlap and purple Inflorescence (July-September)

- $\quad 15-50 \mathrm{~cm}$ dense panicle

- Purplish to whitish

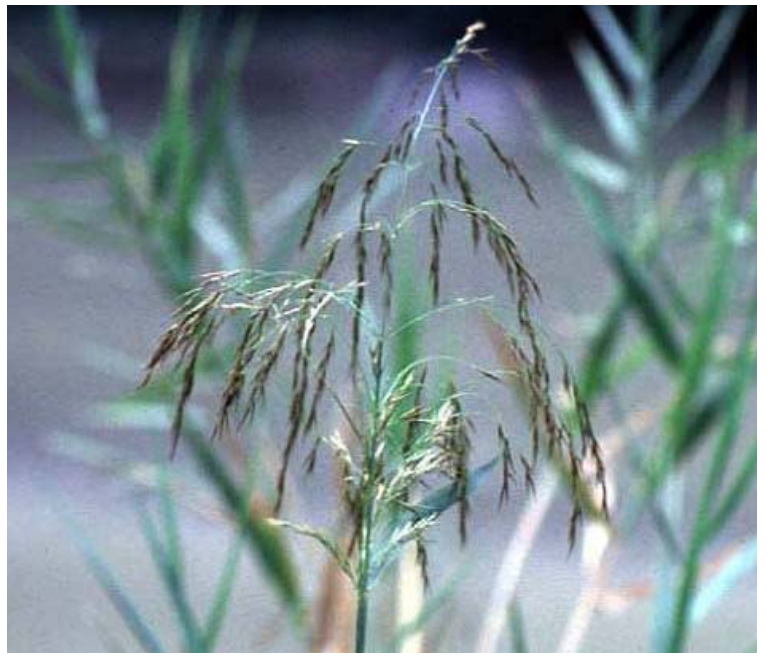

(C) James Manhart

Texas A\&M University

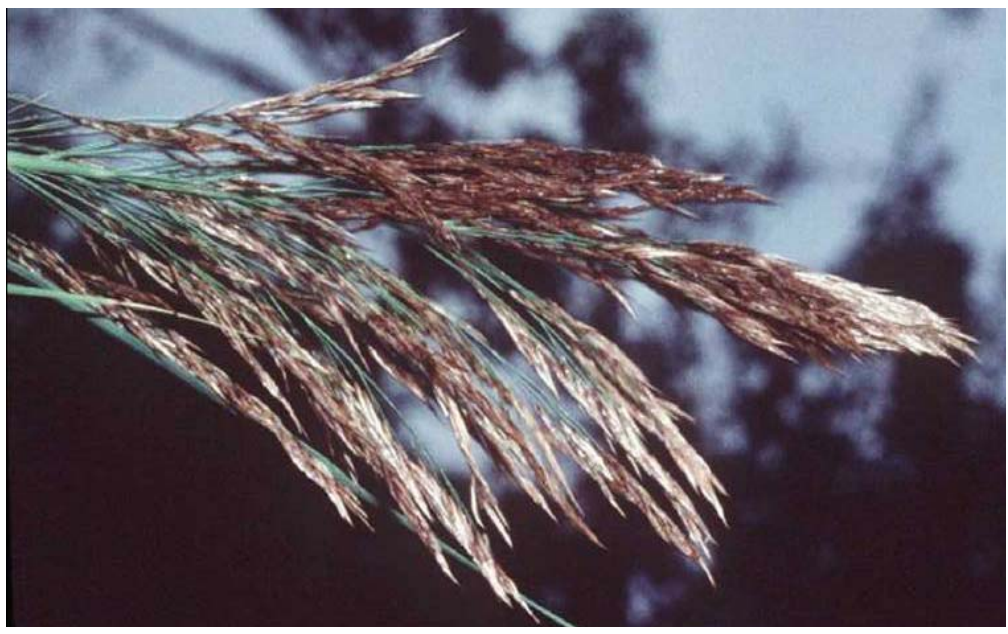

USDA, NRCS, 1995-Midwestern Wetland Flora

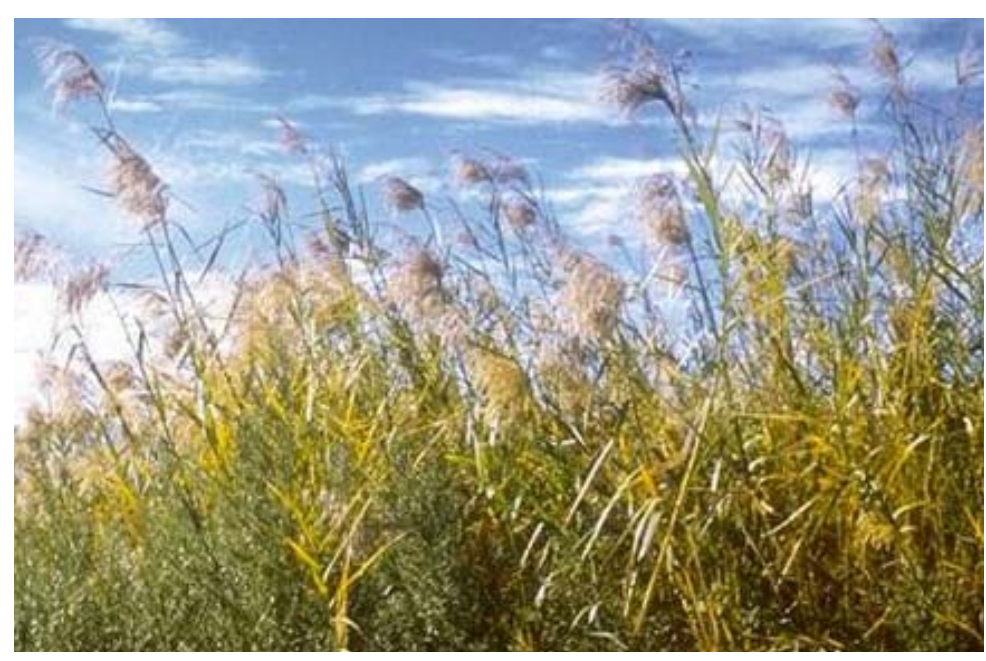

Charles Webber

California Academy of Sciences

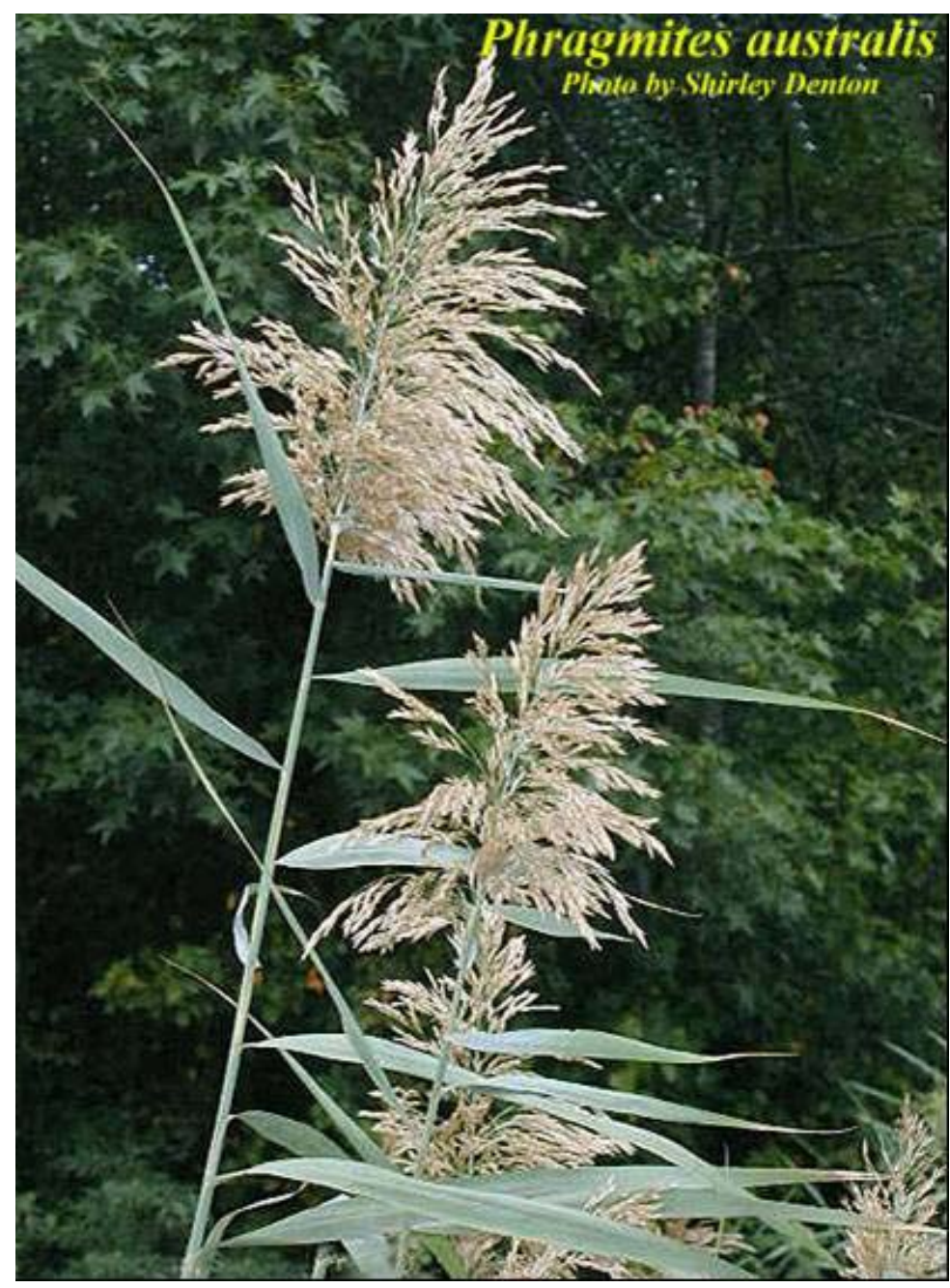

C 2002 Institute for Systematic Botany 
Polygonum lapathifolium (Pale smartweed)

$\begin{aligned} & \text { - Native, annual } \\ & \text { Stems } \text { Ascending to erect, up to } 1 \frac{112}{2} \text { meters } \\ & \text { - } \text { Red and swollen at the nodes }\end{aligned}$ Leaves

- Alternate, petioled, up to $20 \mathrm{~cm}$ long

- Blades lanceolate, often hairy below

- Sheaths are w/o bristles

Inflorescence (July-October)

- Range in color from white to pale pink

- Born in stalks, on long (3-8 cm), dense, drooping spikes

- Flowers never open

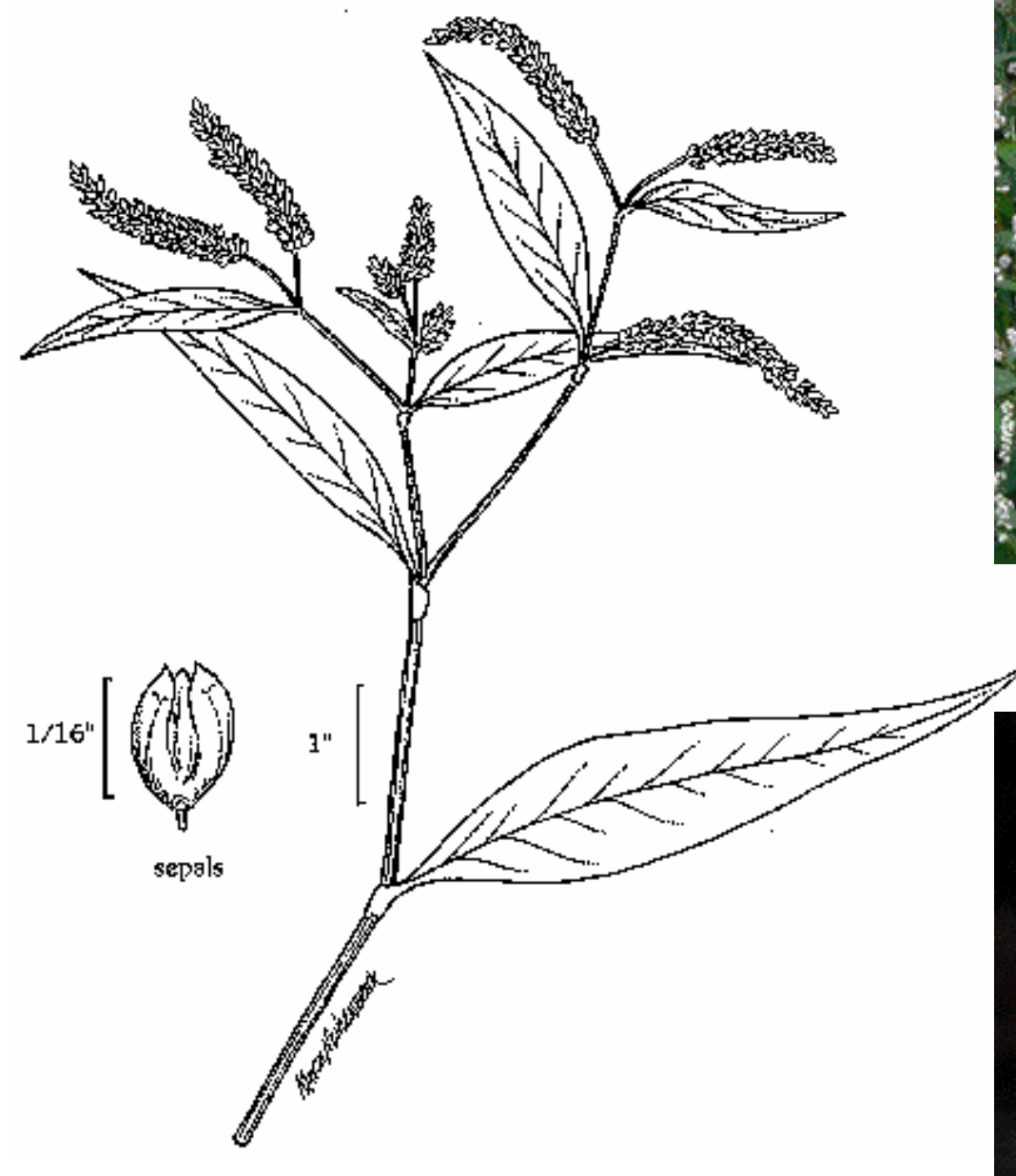

USGS, Northern Prairie Wildlife Research Center

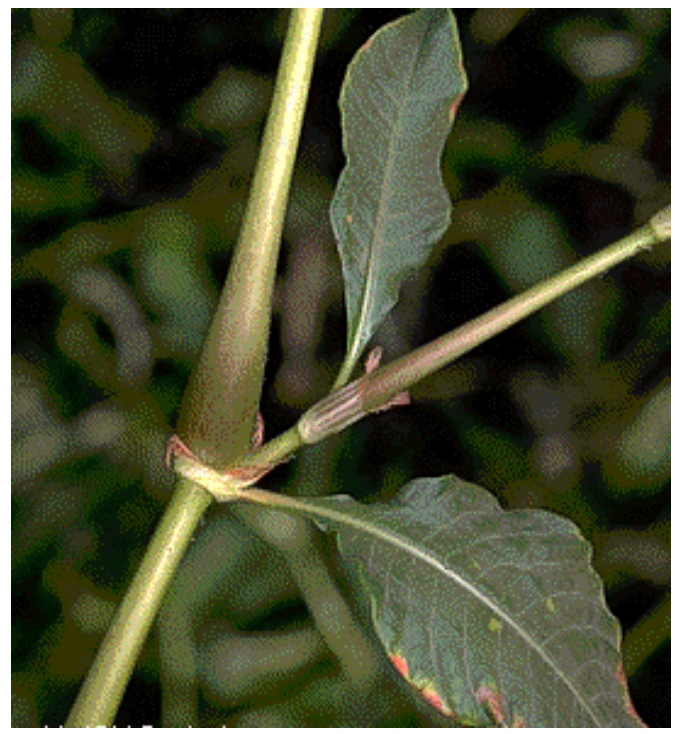

(C) 1996 Regents, University of California UC Statewide IPM Program Jack Kelly Clark, photographer

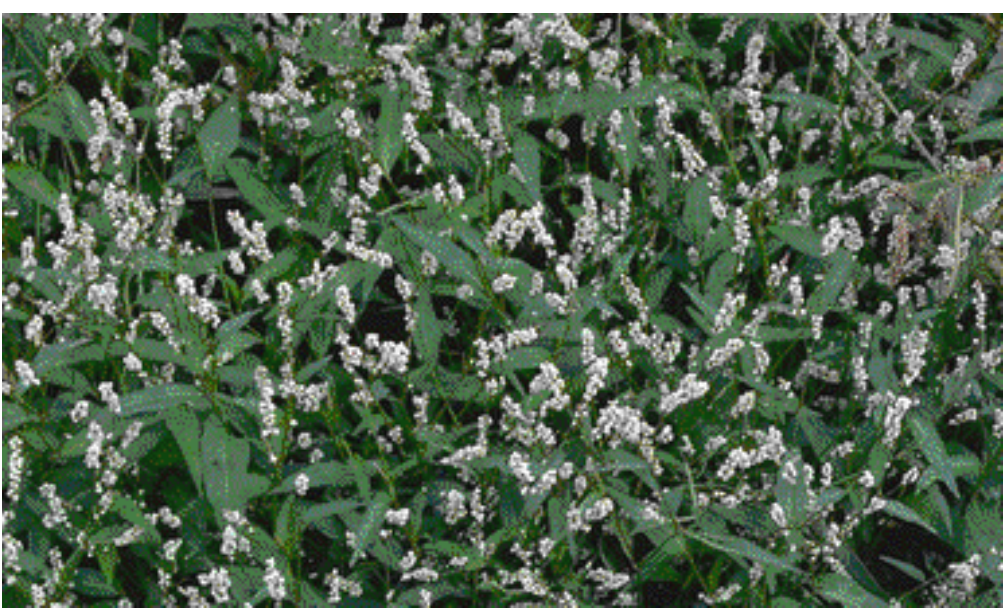

(C) 1996 Regents, University of California UC Statewide IPM Program Jack Kelly Clark, photographer

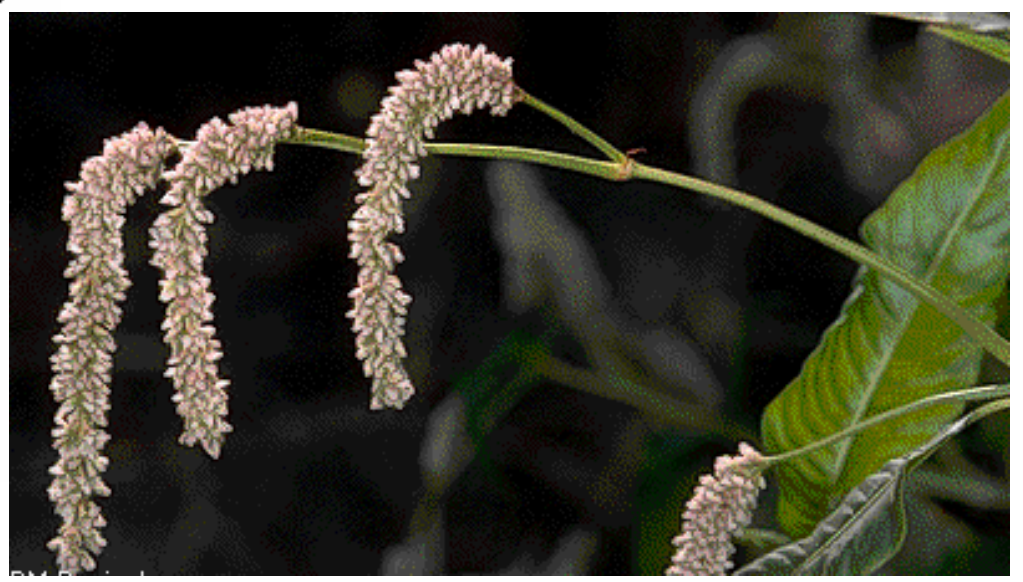

C 1996 Regents, University of California UC Statewide IPM Program Jack Kelly Clark, photographer 
Polygonum punctatum (Dotted smartweed)

- Native, perennial

- Lower branches sometimes rooting at the nodes, usually bearing rhizomes and stolons

Stems

- Upright, usually slender, up to $3 \mathrm{~m}$ tall, but usually shorter

- Usually smooth

Leaves

- Bristly sheaths on the stem

- Alternate, simple, elliptic to lanceolate

- Up to $15 \mathrm{~cm}$ long, $2 \mathrm{~cm}$ wide

- Usually smooth, but occasionally with stiff, sharp hairs on lower surface

Inflorescence (July-October)

- Many flowers arching or erect, interrupted racemes, the racemes $5-8 \mathrm{~cm}$ long

- 6 sepals that are partly united, white to greenish white, petal-like, the surface covered with black dots

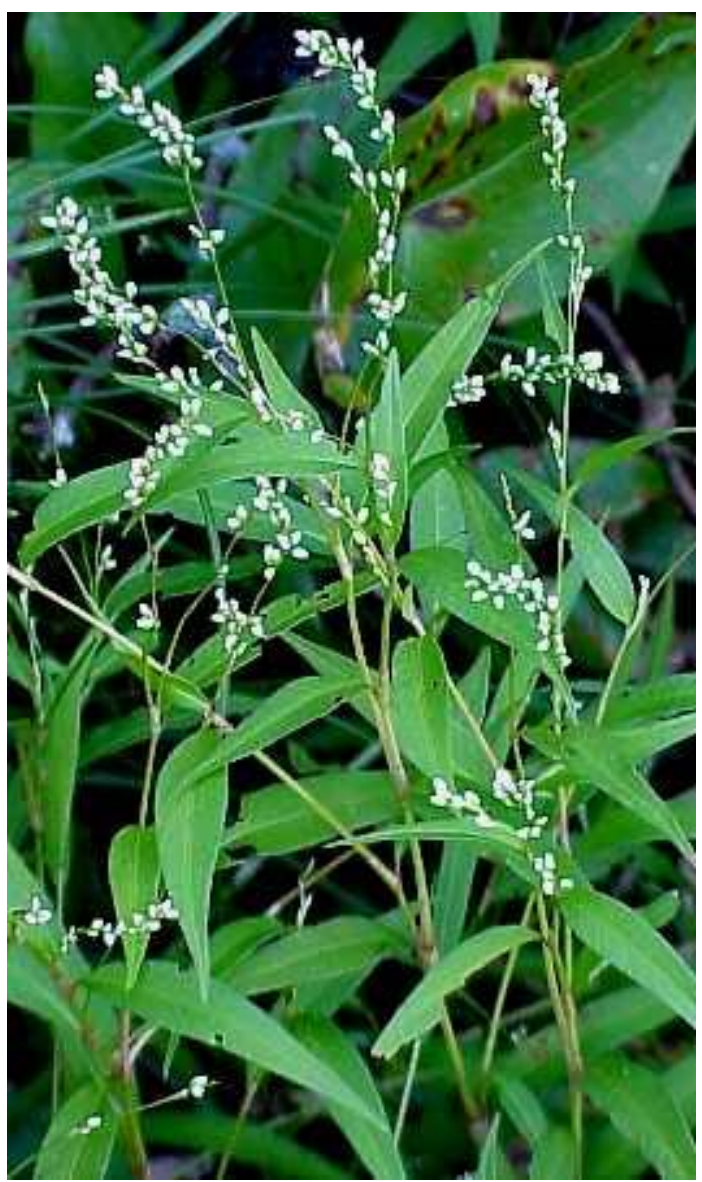

1999 Wisconsin Department of Natural Resources



Robert H. Mohlenbrock 


\section{Polypogon Monspeliensis (Rabbitsfoot grass)}

- Non-native annual

Stems

- Decumbent to erect

- $2-10 \mathrm{dm}$

Leaves

- Leaves are rough along edges, but otherwise smooth - also conspicuously ridged on the upper surface

- Ligule is irregularly toothed and minutely hairy

- No auricles present

- Narrow blades are up to $20 \mathrm{~cm}$ long and 4-6 mm wide

Inflorescence (May to September)

- Both glumes and lemmas are awned (lemma awn is very short)

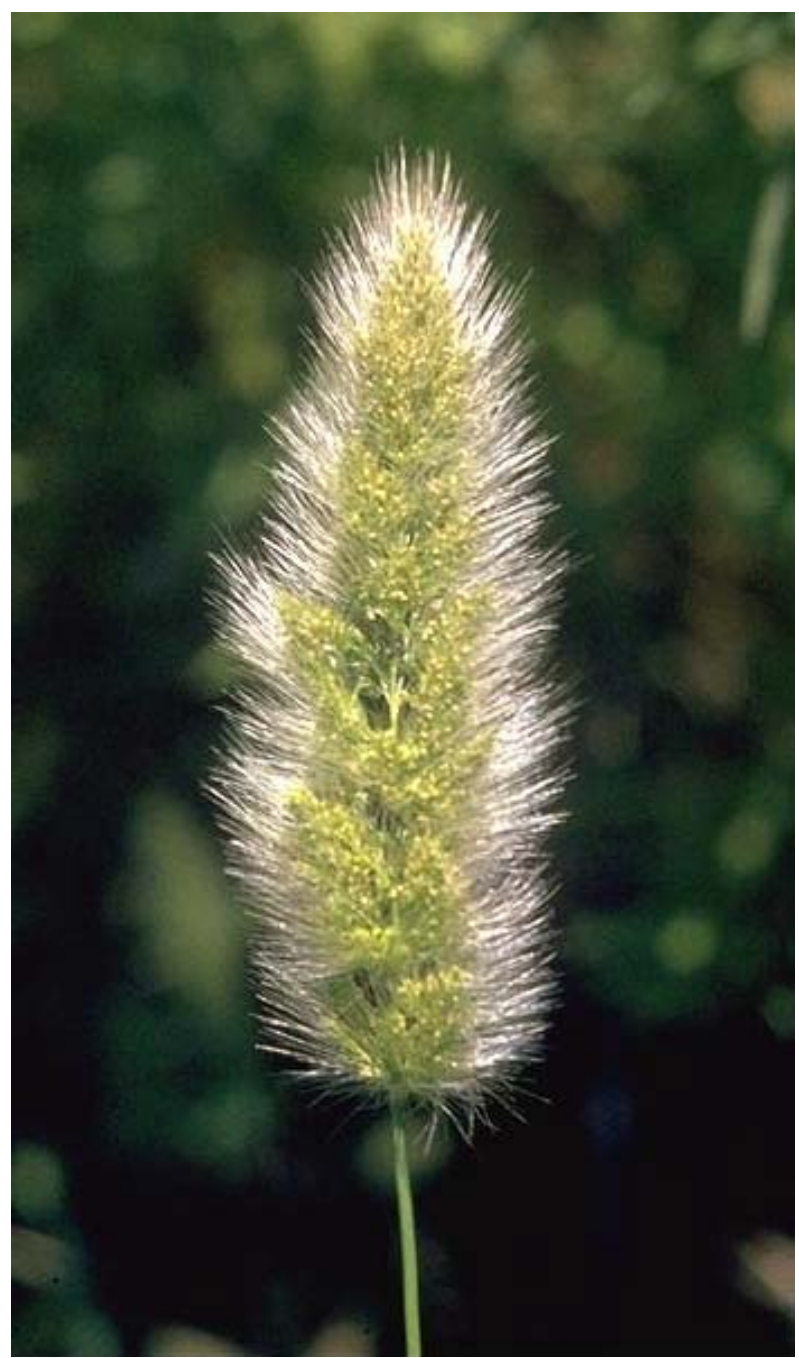

(C) 1995 Saint Mary's College of California Br. Alfred Brousseau, photographer



(C) 1995 Saint Mary's College of California Br. Alfred Brousseau, photographer

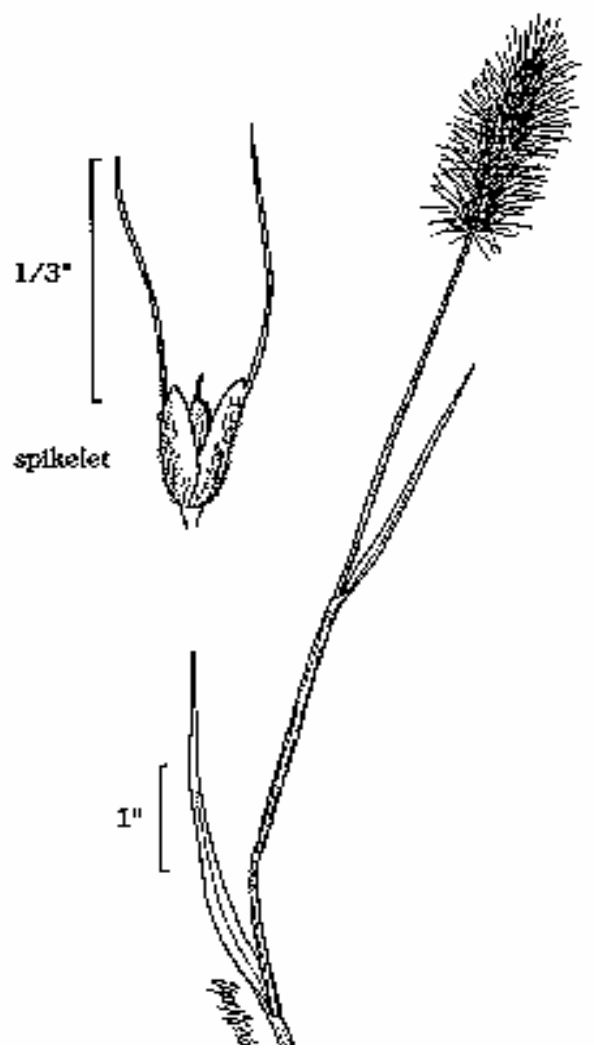

USGS, Northern Prairie Wildlife Research Center 


\section{Portulaca oleracea (Common purslane)}

- Not native, annual

\section{Stems}

- Prostrate, spreading

- Up to $30 \mathrm{~cm}$ long

Leaves

- Stalkless (sessile), alternate or opposite

- 1-5 cm long, ovate or spoon-shaped

- Generally succulent, smooth, shiny and flat Inflorescence

- Flowers solitary or in clusters of 2-5 at stem tips

- Flowers 3-5 mm, yellow with 5 petals

- Sepals 3-5 mm, green or reddish

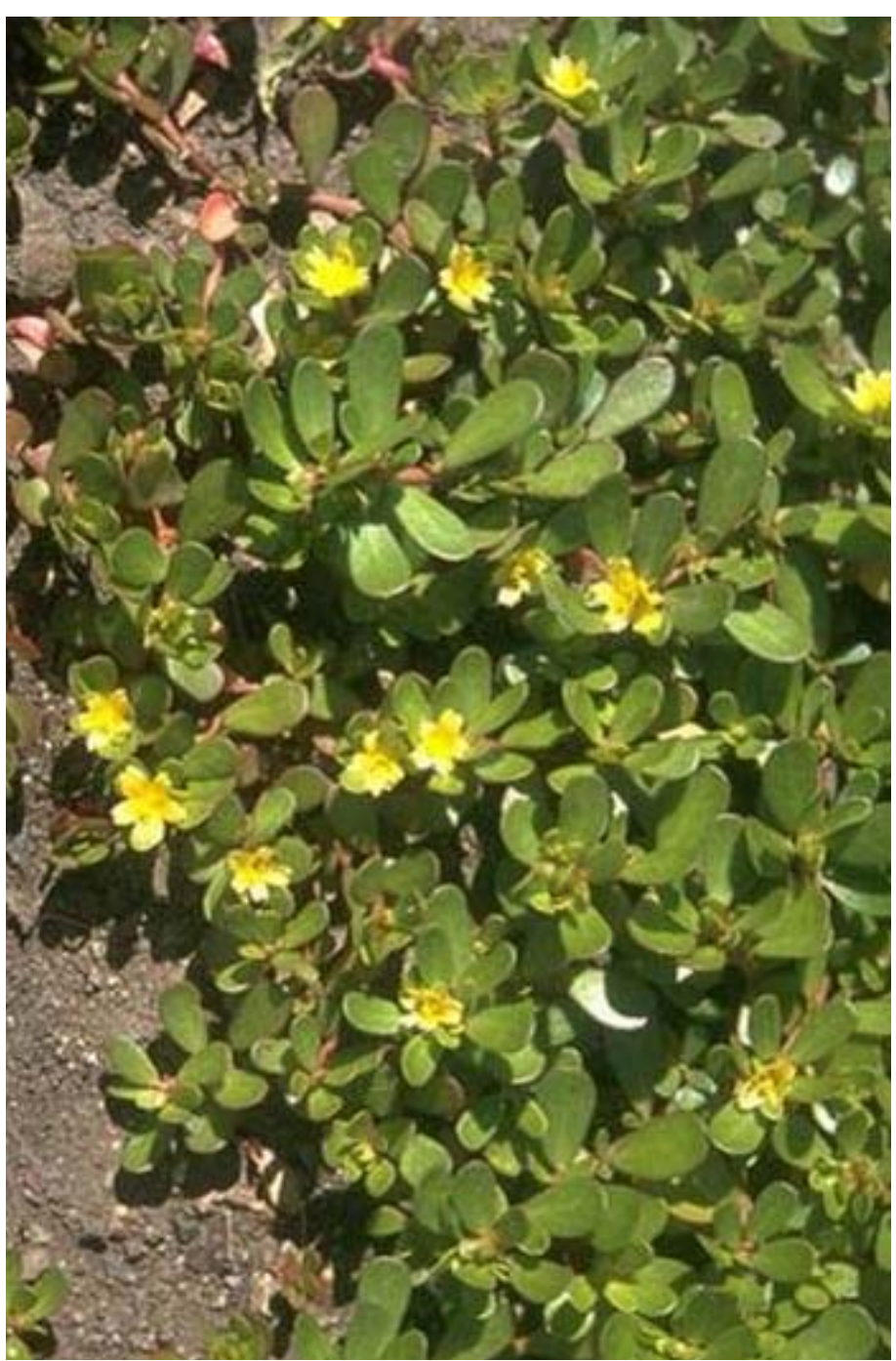

(C) 1995 Saint Mary's College of California Br. Alfred Brousseau, photographer

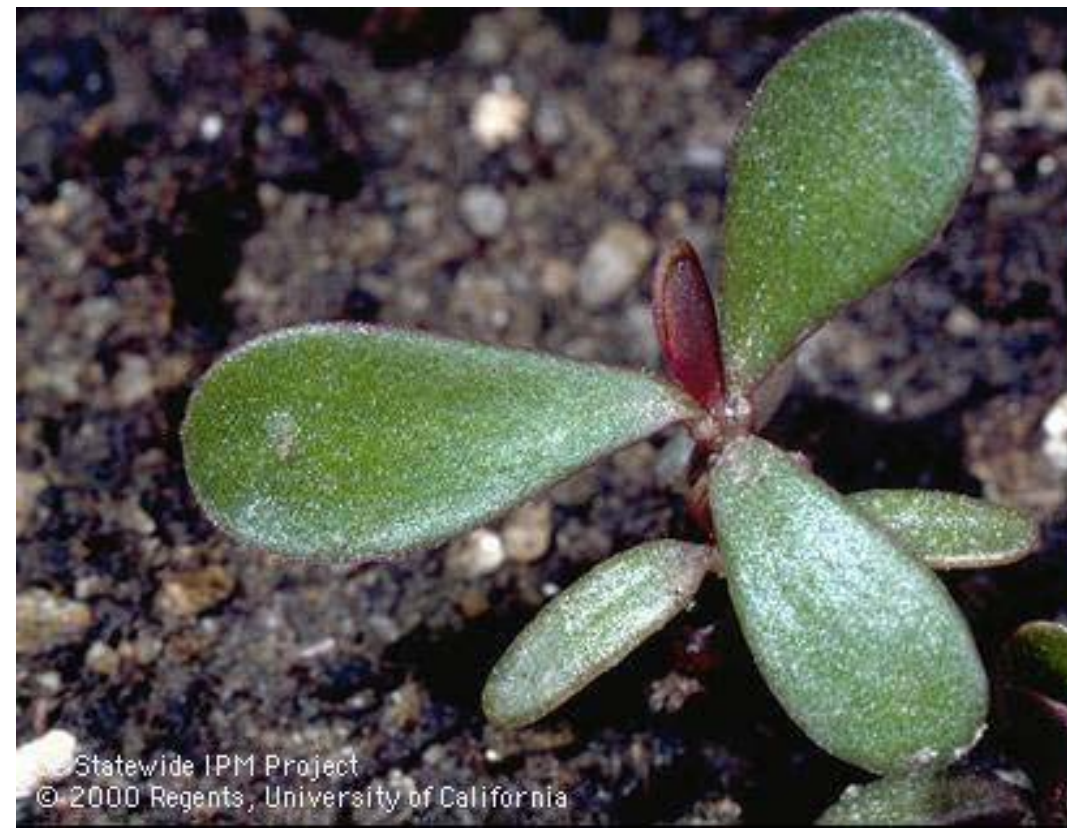

Jack Kelly Clark, photographer

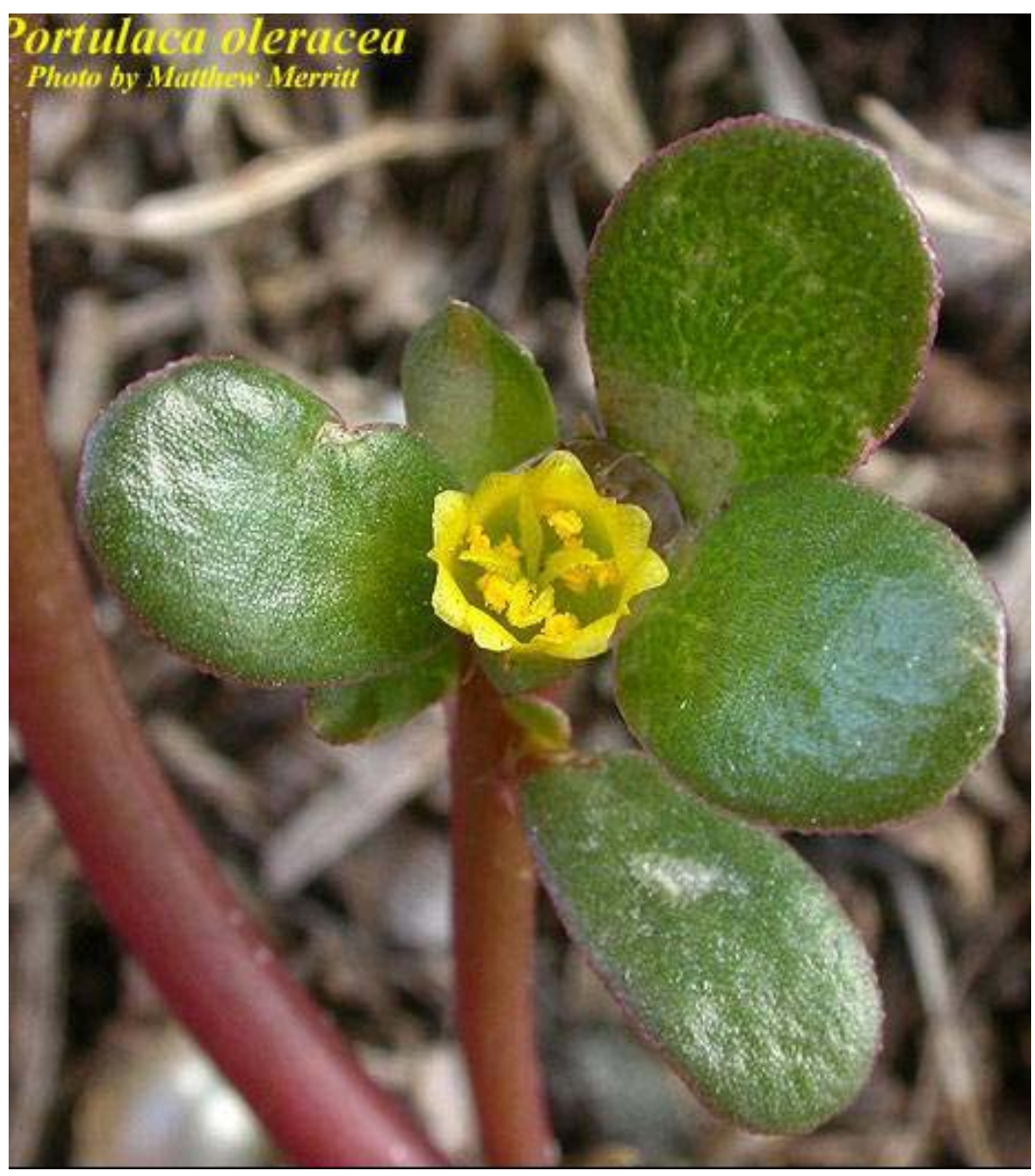

(C) 2002 Institute for Systematic Botany University of South Florida Matthew Merritt, photographer 
Psilocarphus spp. (Woolly Marbles)

- Annual

- Gray to green in color

- Often covered in densely matted hairs

Stems

- Generally several from base and spreading

- Less than $20 \mathrm{~cm}$

Leaves

- Simple, generally opposite and sessile

- Uppermost appear alternate or whorled, generally pressed against heads

- Less than $3 \mathrm{~cm}$

- More or less obtuse, entire

Inflorescence

- Heads disc-shaped, solitary or in small groups

- Bracts like leaves

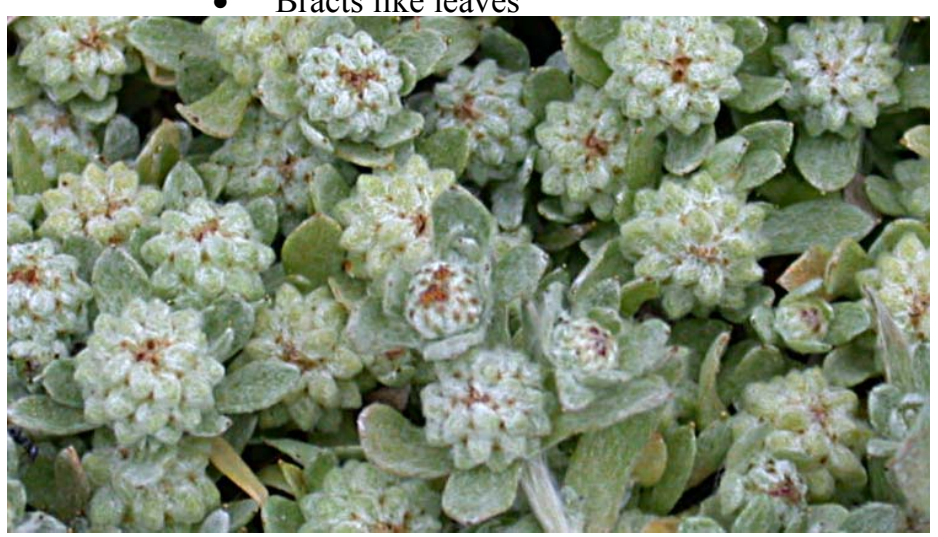

Psilocarphus tenellus

(C) 2002 Dean Wm. Taylor

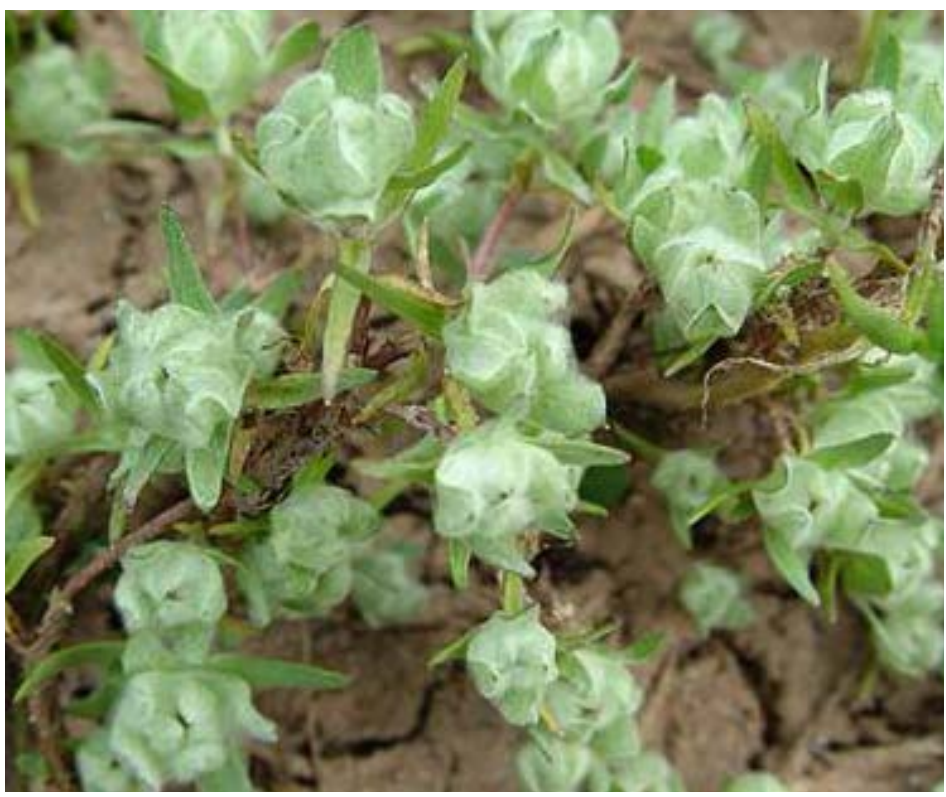

Psilocarphus brevissimus var. brevissimus

(C) 2004 Carol W. Witham

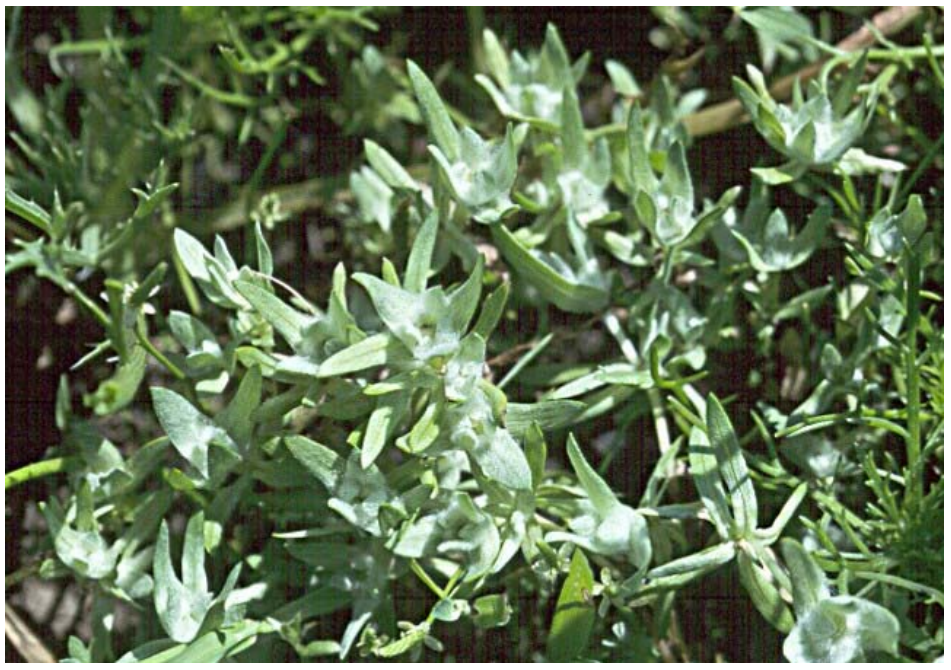

Psilocarphus brevissimus

(C) 1998 Dean Wm. Taylor

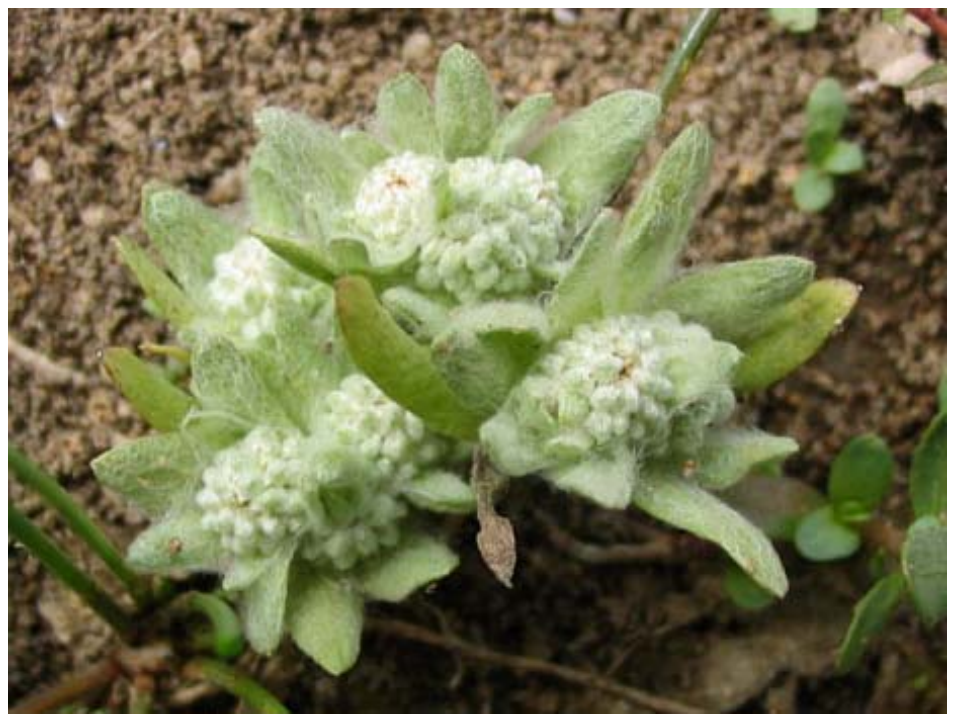

Psilocarphus brevissimus

(C) 2003 Vince Scheidt

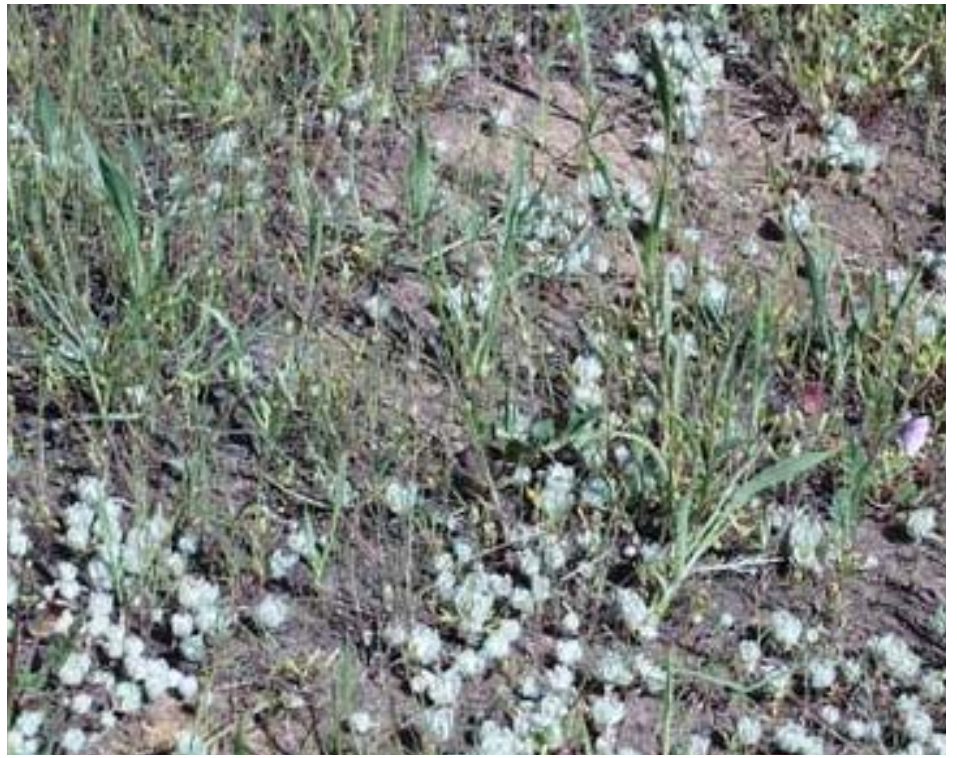

Psilocarphus brevissimus var. brevissimus

(C) 2001 Craig Moore

California Department of Transportation 


\section{Rumex spp. (Dock)}

\section{Stems}

- Generally upright and unbranched below inflorescence

- Less than 2 meters tall

- Ridged with swollen nodes

Leaves

- Alternate, with petioles

- Blades are less than $50 \mathrm{~cm}$

- Generally clustered near ground

Inflorescence

- Bracted clusters generally arrayed in upright panicles

- Individual flowers generally less than $3 \mathrm{~mm}$ in diameter

- Flowers don't fall off (persistent)

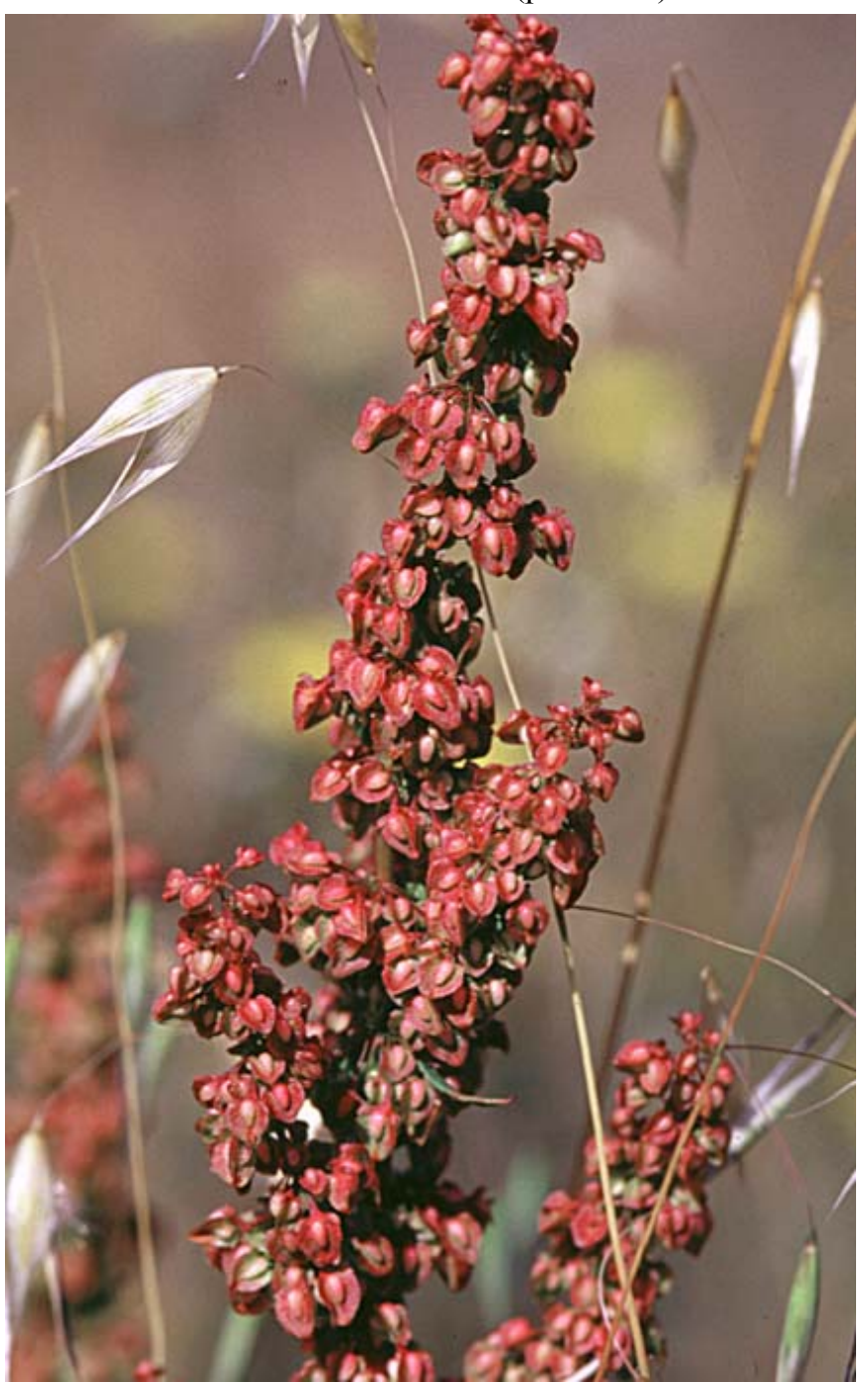

Rumex crispus

(C) 2000 Joseph Dougherty

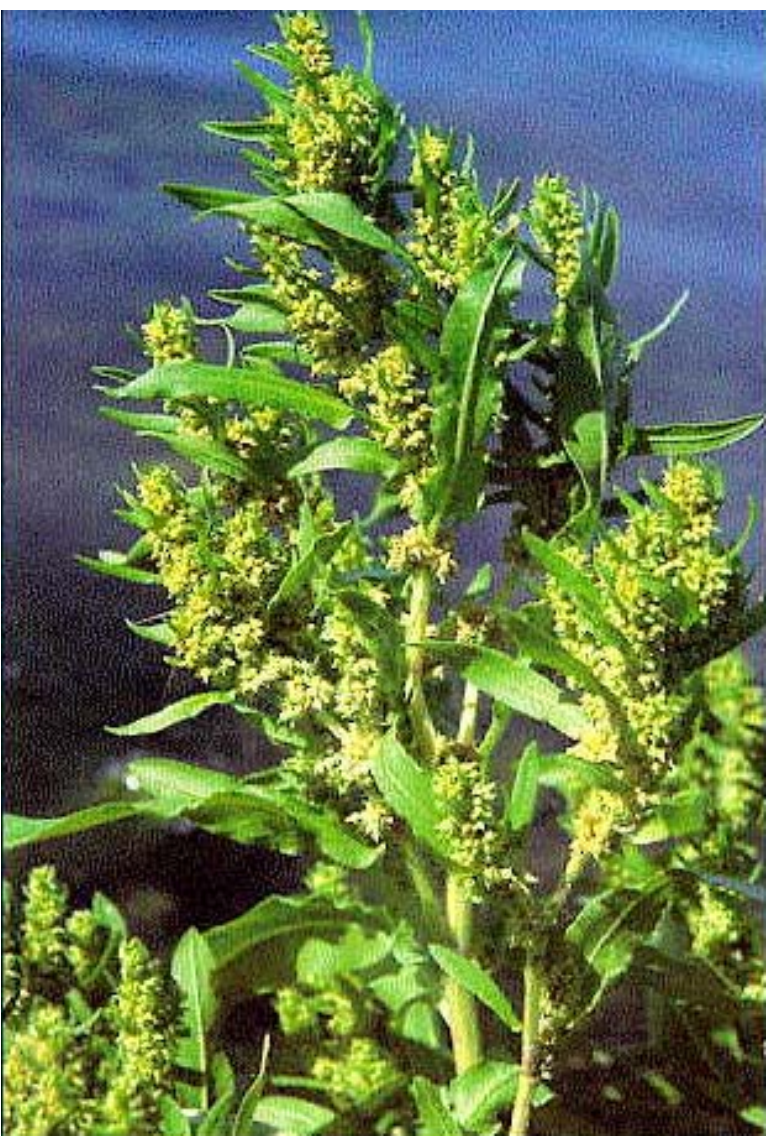

Rumex maritimus

Joe F. Duft, photographer

Northern Prairie Wildlife Research Center

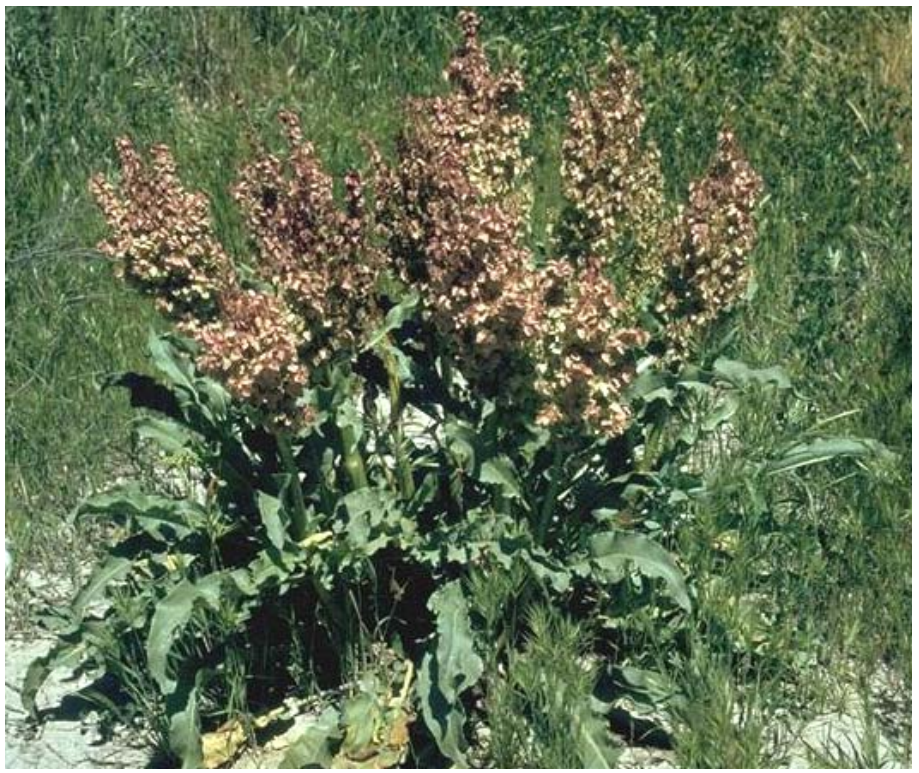

Rumex hymenosepalus

(C) 1995 Saint Mary's College of California

Br. Alfred Brousseau, photographer 
Sagittaria calycina (Hooded arrowhead)

- Native, annual

Leaves

- Petiole un-angled

- Emergent blades arrowhead shaped, 5-15 cm Inflorescence

- Single plant with two different flowers (bisexual and staminate)

- Lowest node with 2 bisexual flowers; white petals with green-yellow spot at base

- Staminate flowers above; filaments papillate

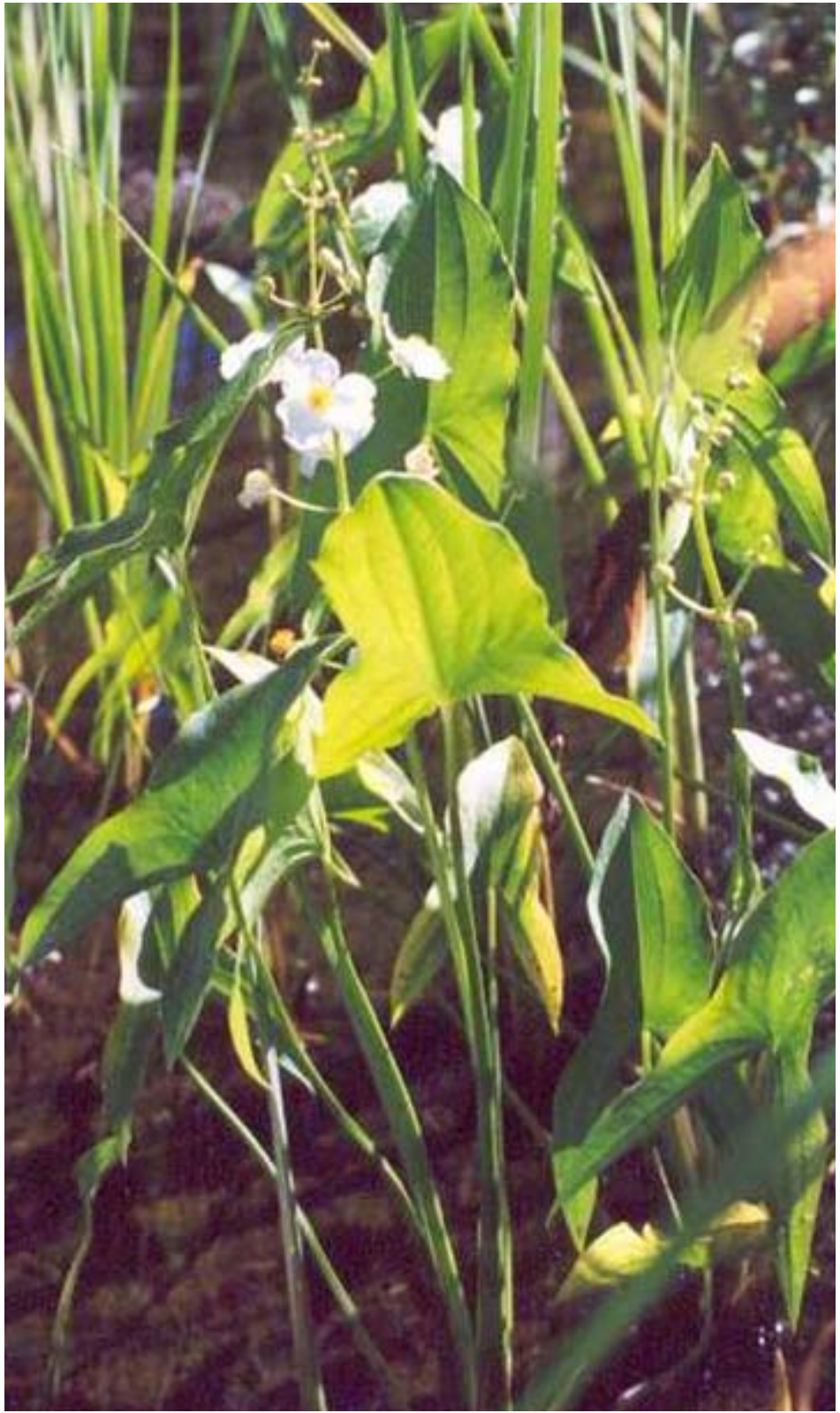

Jennifer Anderson

USDA-NRCS PLANTS Database

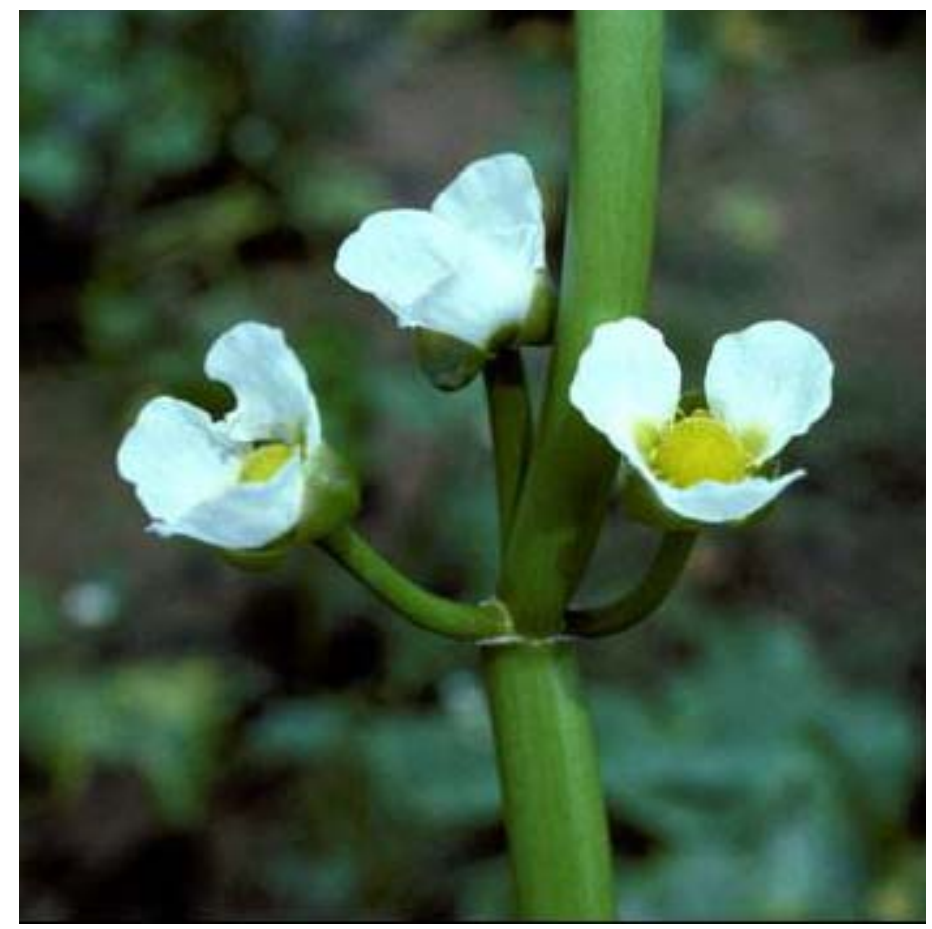

Edward W. Chester, photographer

Austin Peay State University

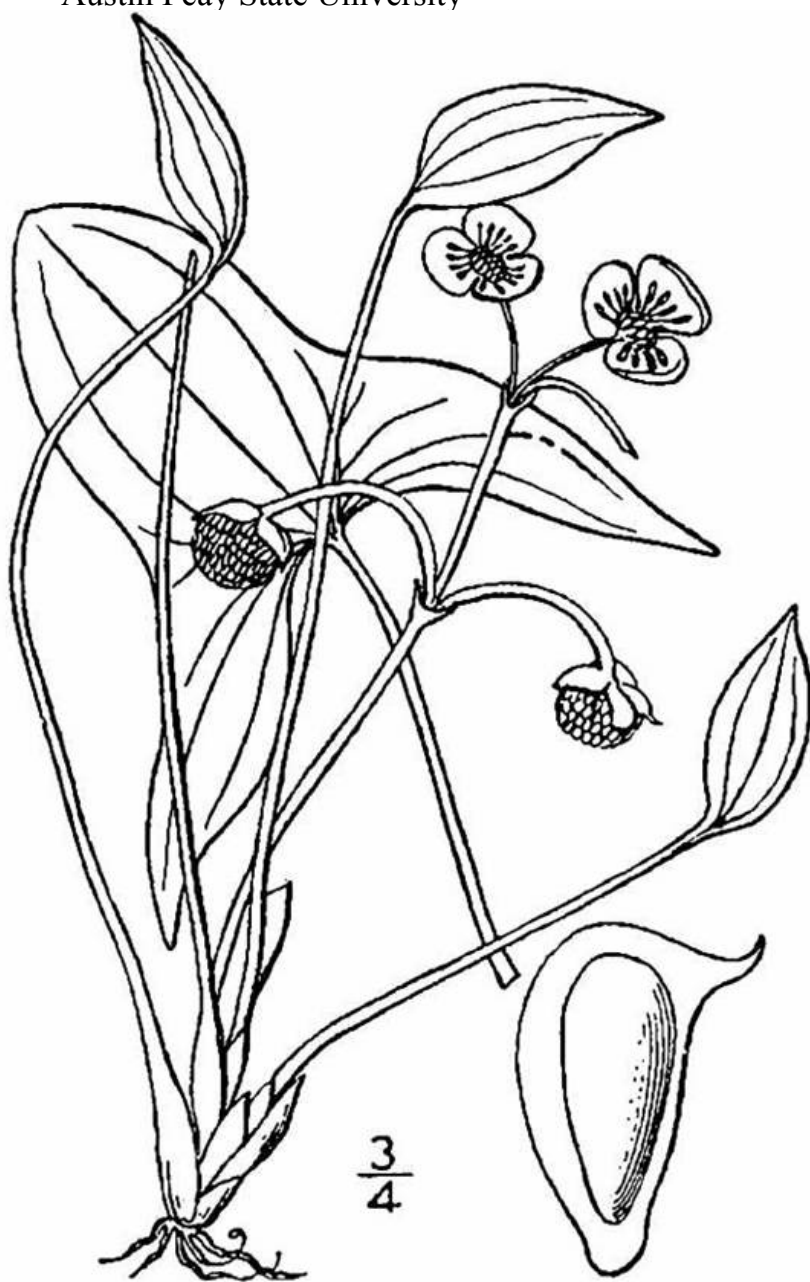

1913 Britton, N.L., and A. Brown USDA-NRCS PLANTS Database 
Salicornia spp. (Pickleweed)

- Annual to subshrub

Stems

- Generally many branched, jointed

- Internodes green, hairless and fleshy Leaves

- Opposite, sessile and decurrent Inflorescence (April-September)

- $\quad$ Spike, terminal, cylindrical and dense

- Bracts are scale-like

- Flowers generally 3 per axil, sessile to sunken into axis

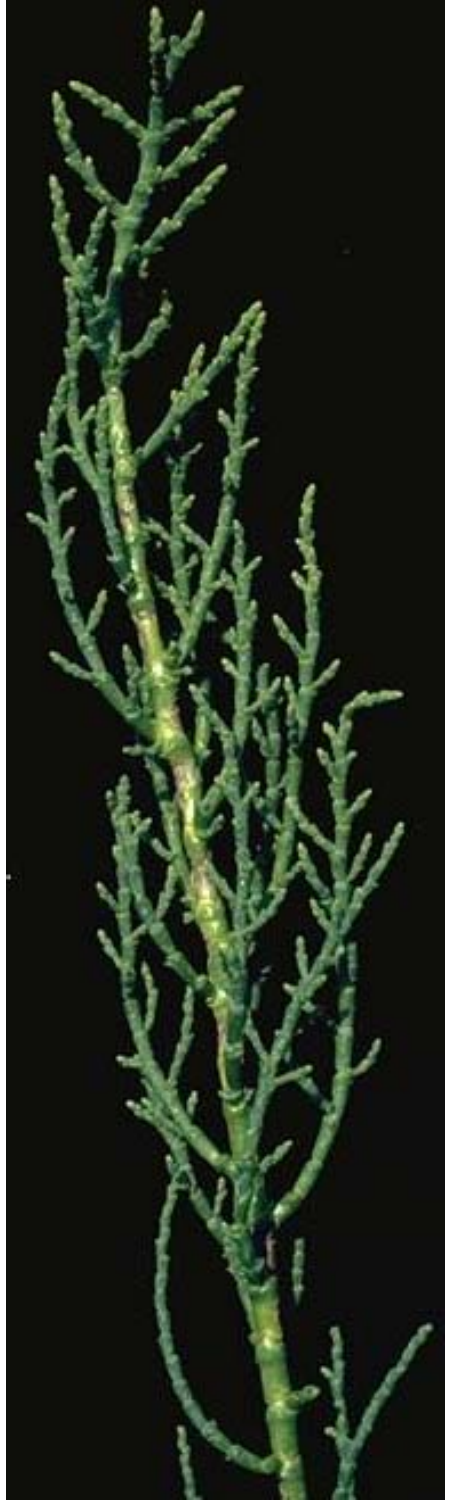

Salicornia virginica

(C) St. Mary's College

Br. Alfred Brousseau

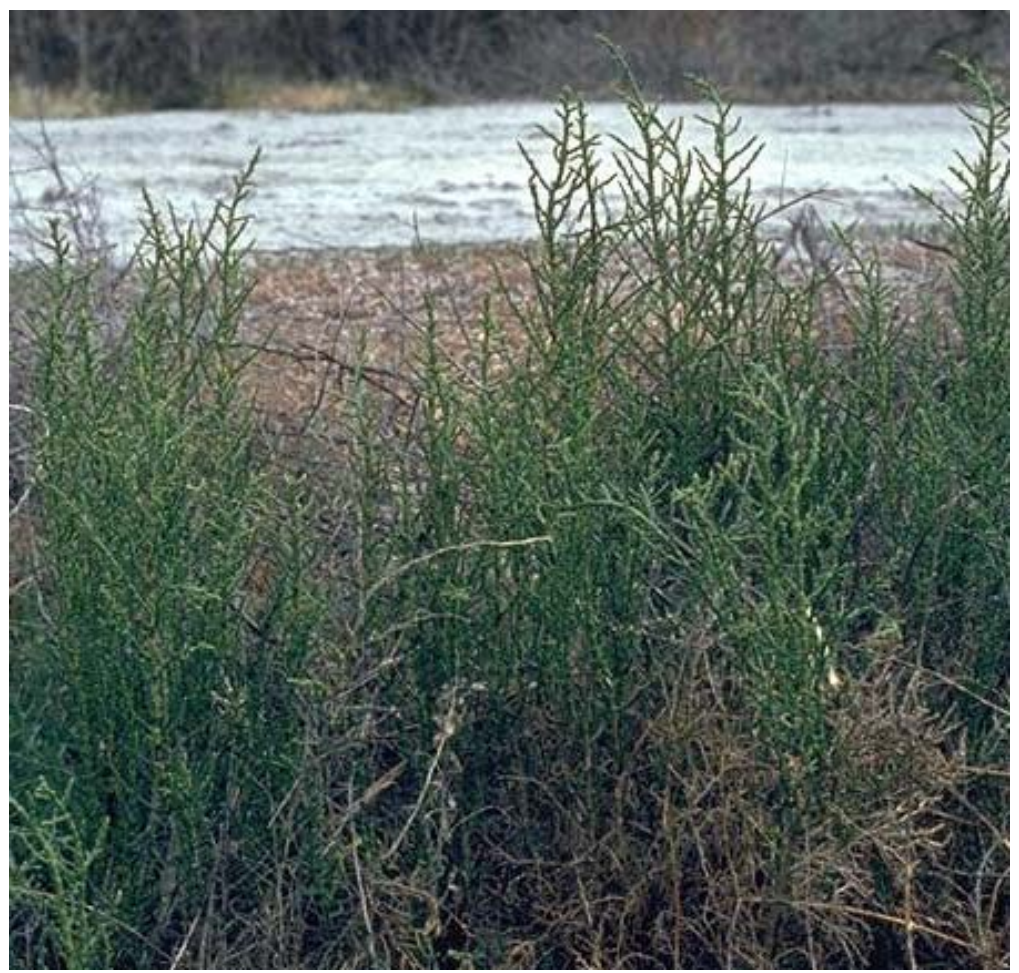

(C) Saint Mary's College of California

Br. Alfred Brousseau, photographer

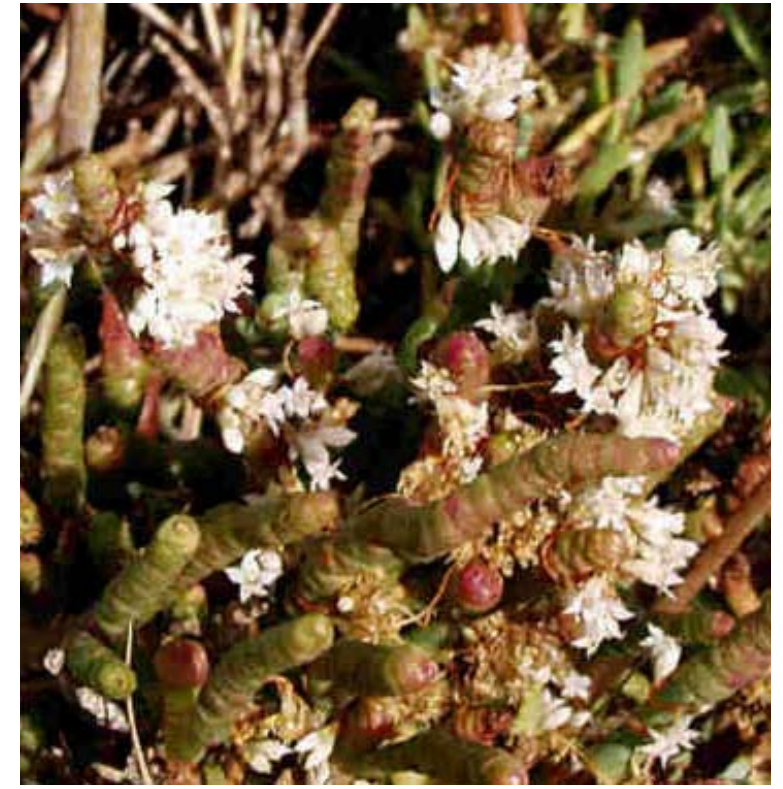

Salicornia virginica

(C) 2001 James Reiter

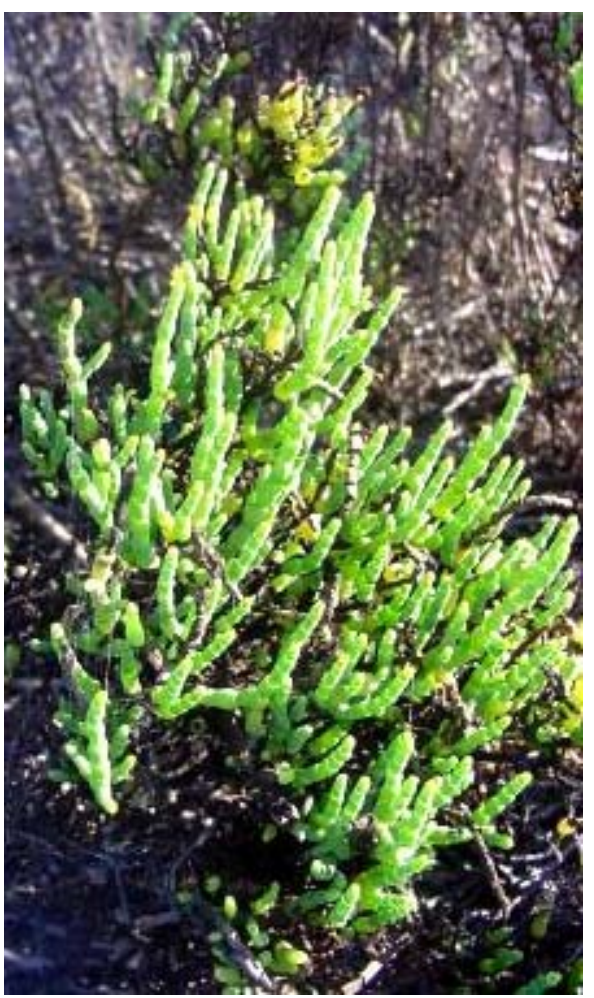

Salicornia subterminalis

Michael Charters

www.calflora.net 
Scirpus maritimus (Alkali bulrush)

- Native, perennial

- Emergent, forming large dense stands in alkaline or saline environments

Stems

- Erect, 3-8 mm wide, up to $1 \frac{1}{2} \mathrm{~m}$ tall

- Triangular with smooth sides

Leaves

- Alternate, more or less cauline with closed sheaths

- 3-12 mm wide, flat to $\mathrm{v}$-shaped

Inflorescence

- Spikelets 4 to many, often in 1 sessile, dense cluster at tip of stem and nestled in 3 or more leafy bract

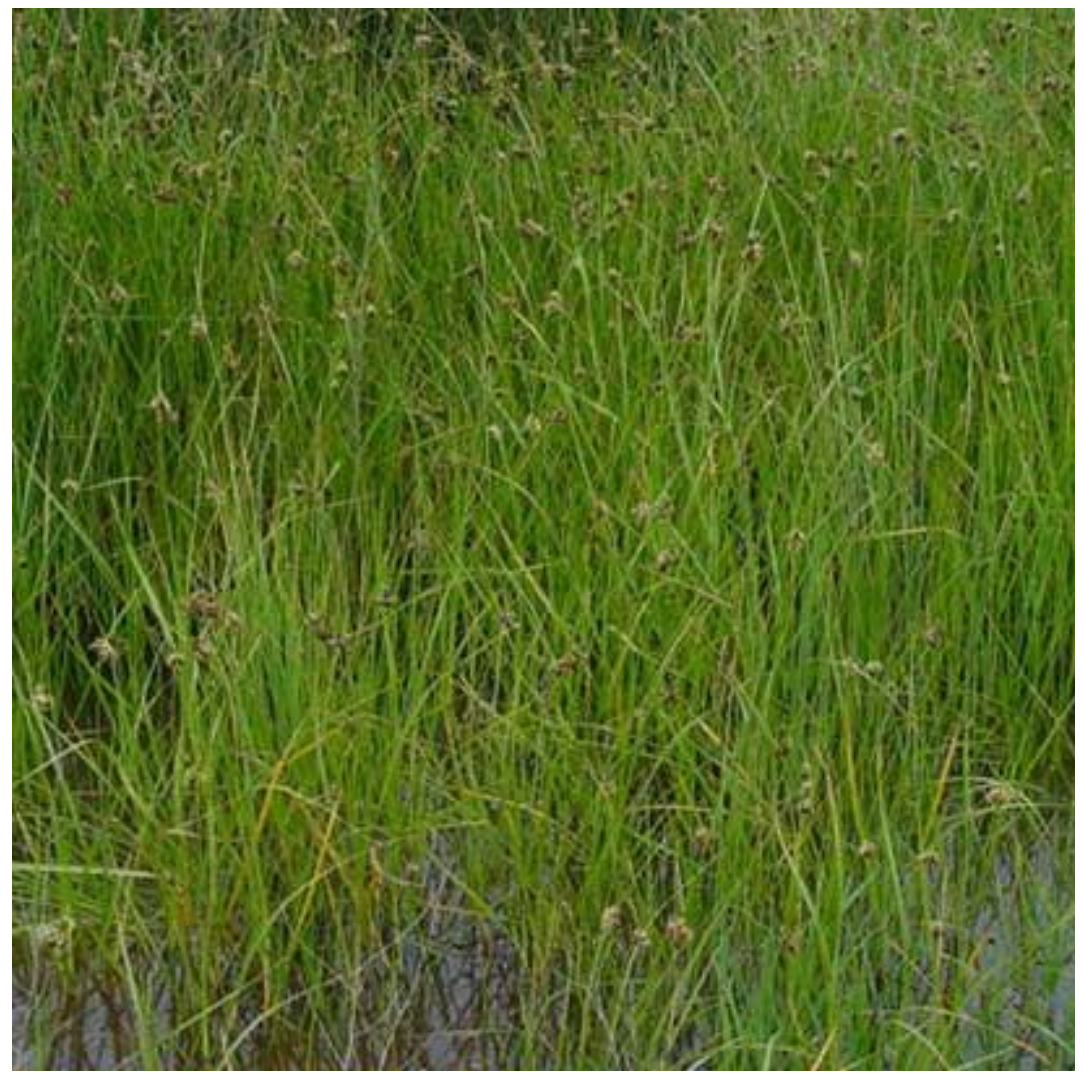

(C) 2000 Herbari Virtual Universitat Illes Balears

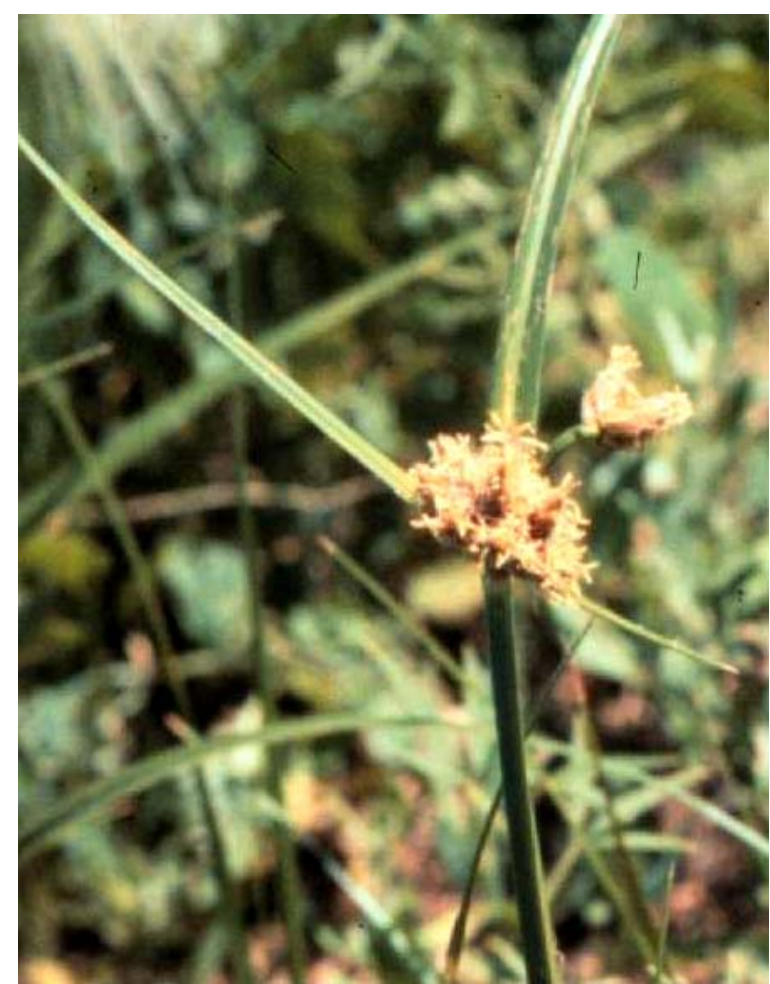

(C) Larry Allain

USDA-NRCS PLANTS Database

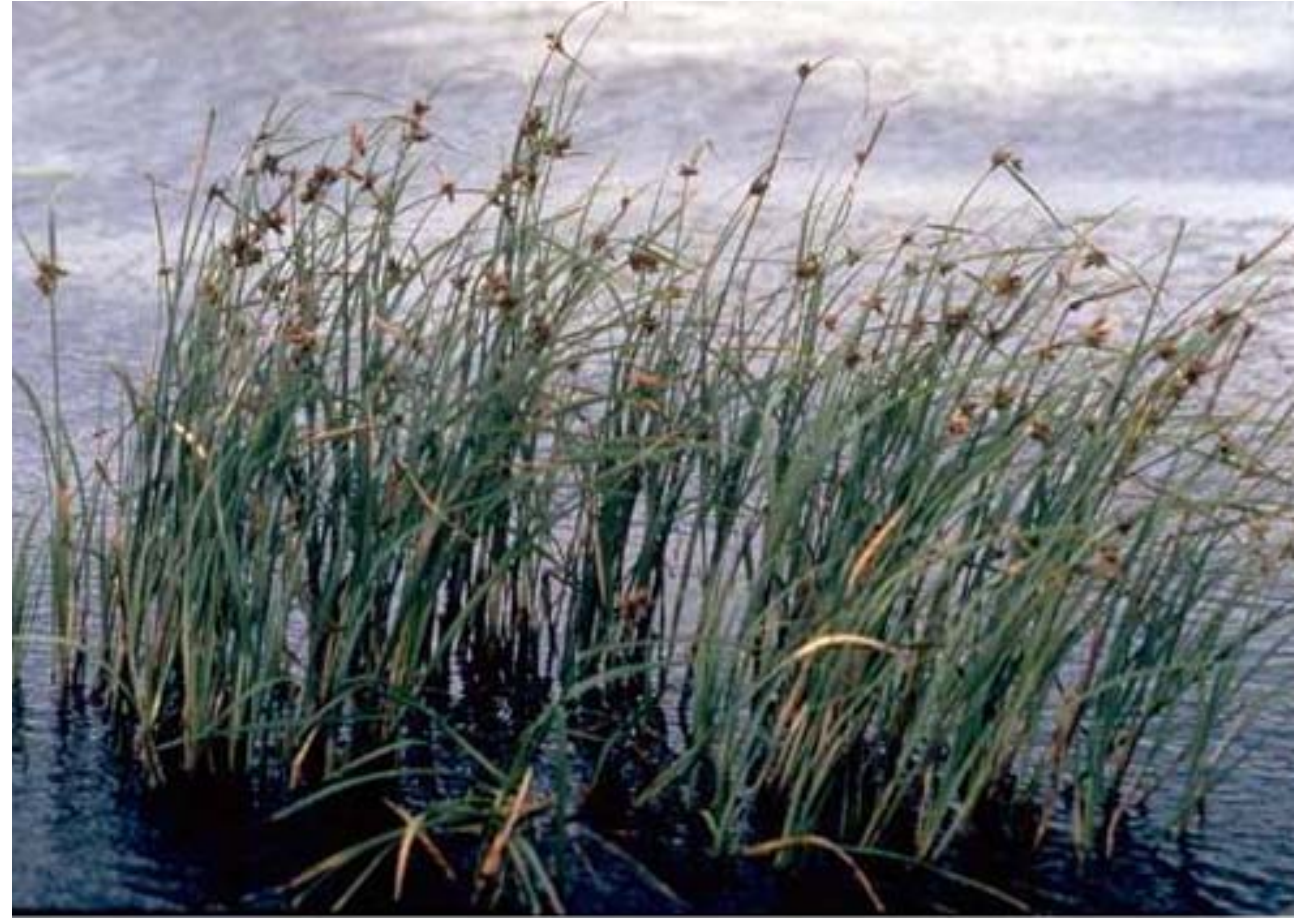

Robert H. Mohlenbrock

USDA-NRCS PLANTS Database 
Scirpus spp. (Bulrush)

\section{Scirpus acutus}

- Stems are green, cylindrical, $1 \frac{1 / 2-4}{\mathrm{~m}}$ tall and 2-12 $\mathrm{mm}$ wide in middle

- Leaves reduced to prominent membranous sheaths at base of stem

- Brownish, inconspicuous flower cluster, or inflorescence is terminal, but appears to be borne at the side of the upper stem, the tip or continuation of which is actually a single, erect bract subtending the inflorescence

Scirpus californicus

- Stems triangular, may be cylindrical at base, $2-4 \mathrm{~m}$ tall and $<10 \mathrm{~mm}$ wide in middle

Scirpus robustus

- Stems $1 / 2-1 \frac{1}{2} \mathrm{~m}$ tall and 4-6 mm wide, sharply triangular

- Leaves cauline, with sheathes clearly veined at top, flat or $\mathrm{v}$-shaped

- Like maritimus $\mathrm{w} /$ larger spikelets

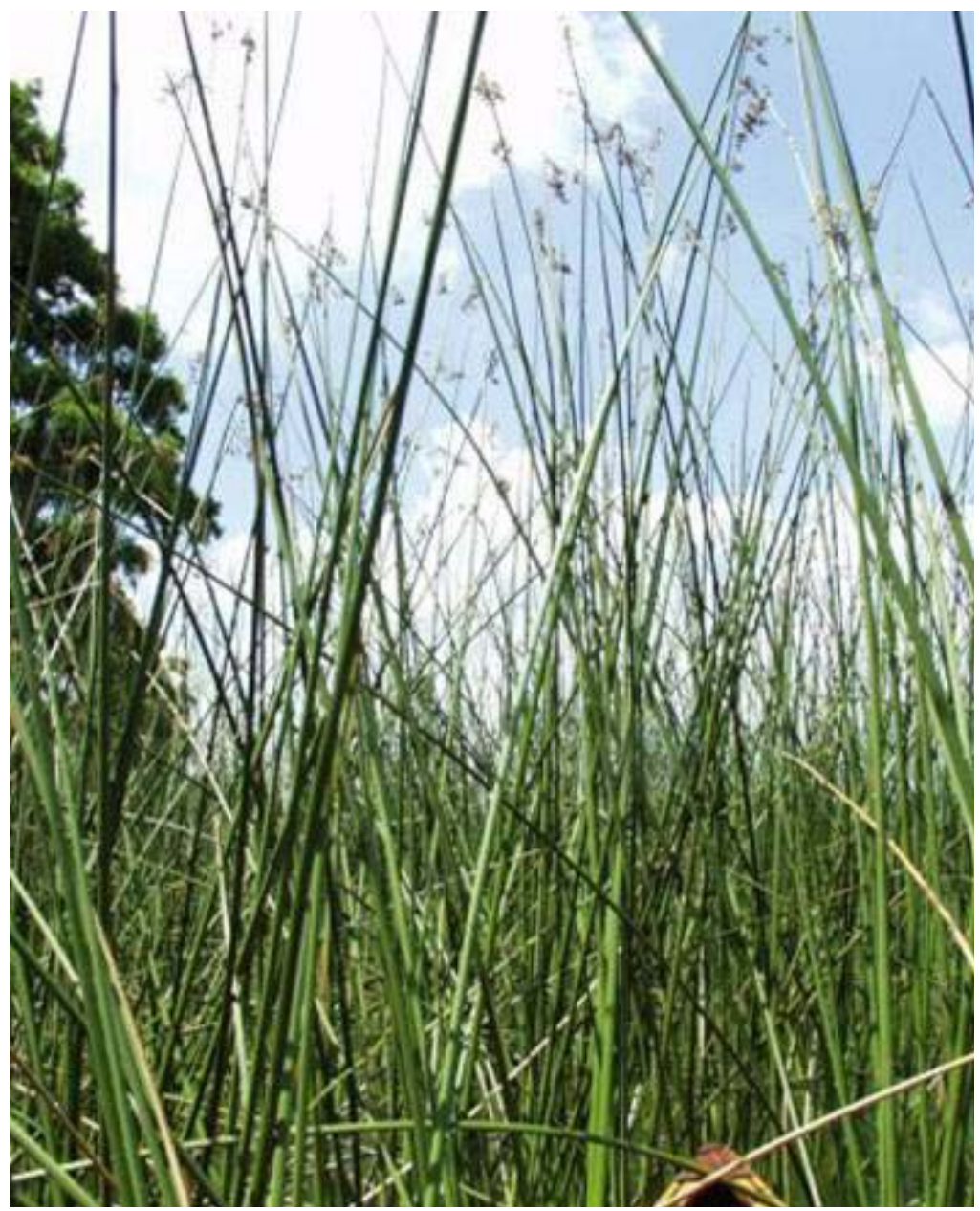

Scirpus californicus

(C) 2002 Institute for Systematic Botany

University of South Florida

Shirley Denton, photographer

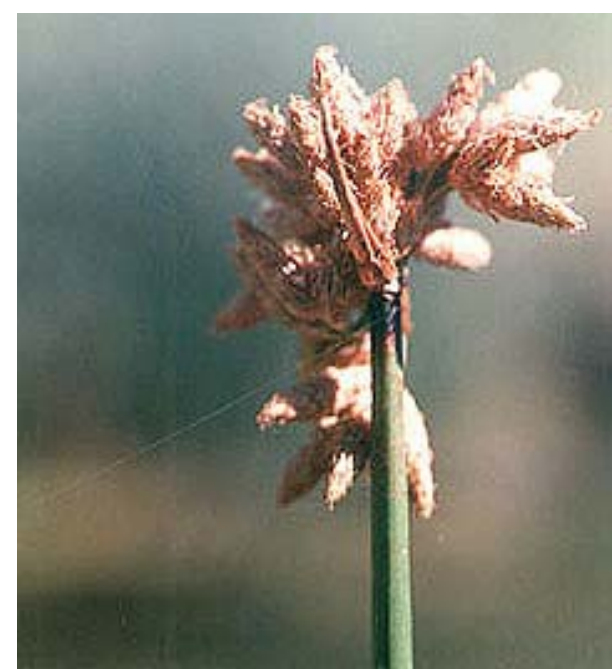

Scirpus acutus

UCLA Botanical Garden

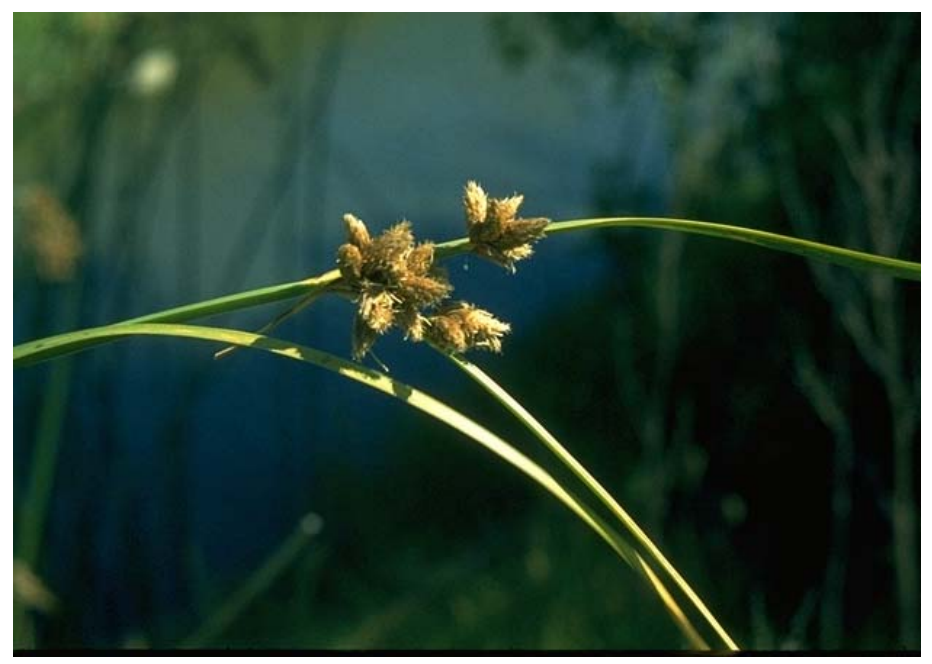

Scirpus robustus

(C) 1995 Saint Mary's College of California

Br. Alfred Brousseau, photographer

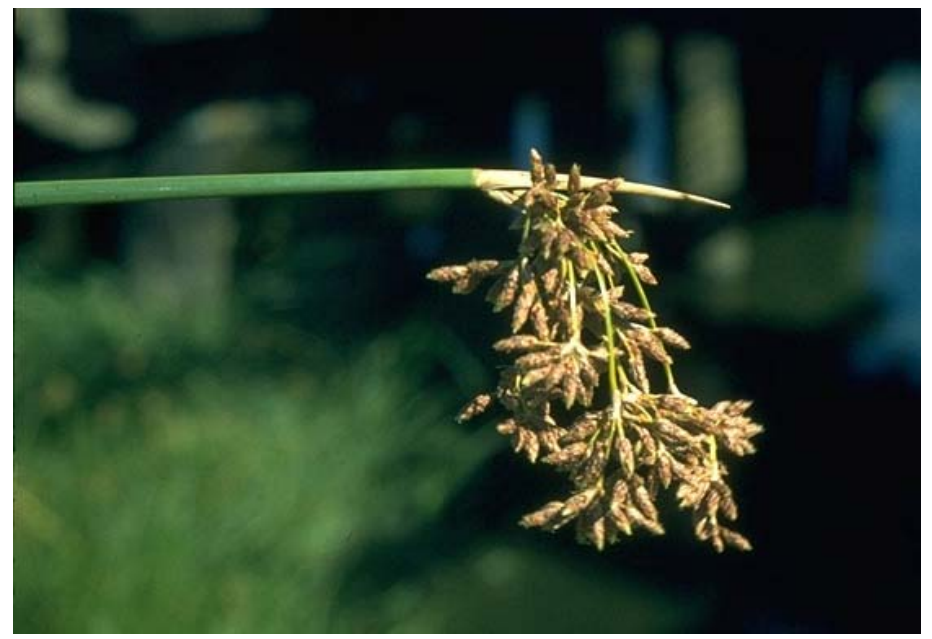

Scirpus californicus

(C) 1995 Saint Mary's College of California

Br. Alfred Brousseau, photographer 
Sorghum halepense (Johnson grass)

- $\quad$ Perennial with rhizomes

Stems

- $\quad$ Erect, internodes generally solid

- $\quad 1 / 2-2 \mathrm{~m}$ long

Leaves

- $\quad$ Flat, linear, drooping and somewhat narrowed toward the rounded base

- Rough margins, usually glabrous

- Conspicuous light-colored midrib and often purple spots occur on the leaf

- Blade flat or folded, $1 / 2-2 \mathrm{~cm}$ wide

- Sheaths generally less than internodes

- Ligule membranous with fringe

Inflorescence

- Panicle-like, generally open, 1-5 dm

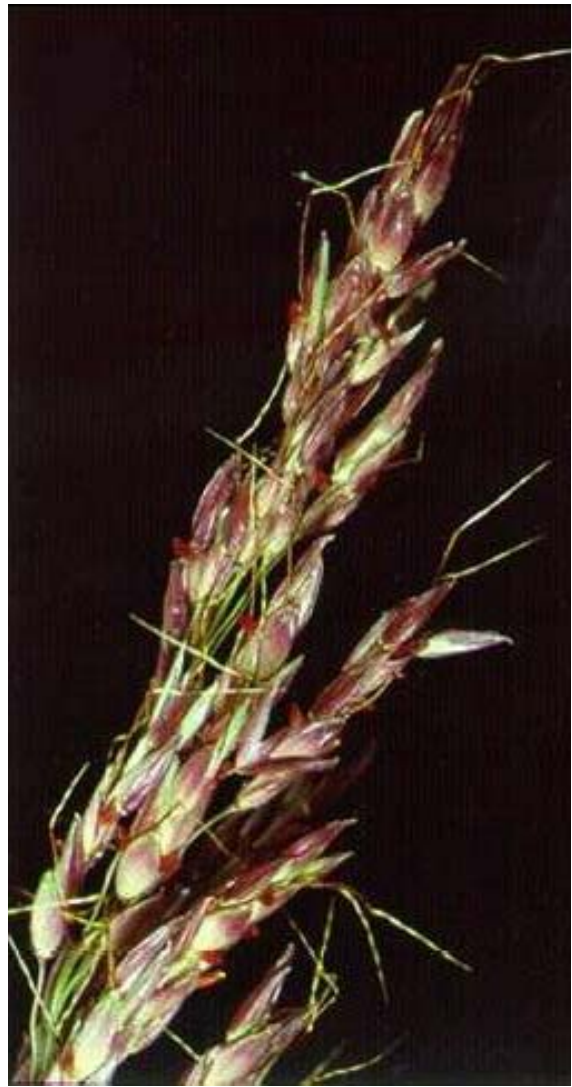

(C) Barry A. Rice

The Nature Conservancy
James Henson

USDA-NRCS PLANTS Database

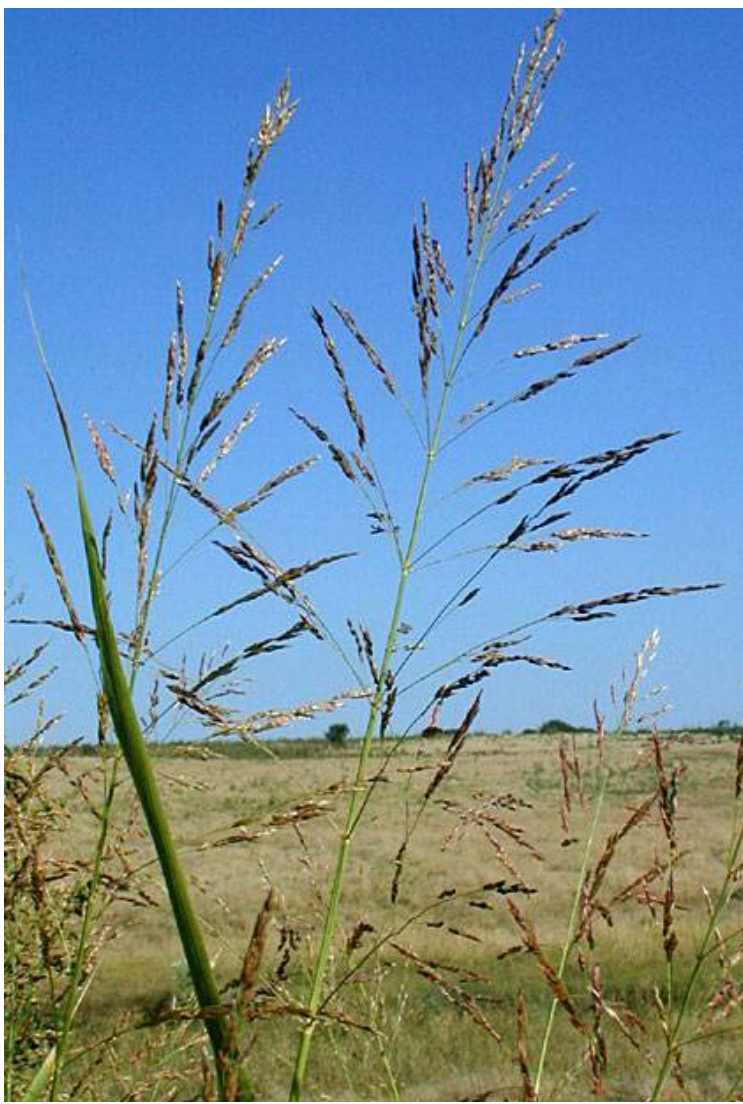

(C) 2001-2002 Mike Haddock 


\section{Spergularia spp. (Sandspurry)}

- Native and non-native species Leaves

- Generally lanceolate and acuminate

- Scarious and entire (smooth edges)

- Blade thread-like to linear with 1 vein Inflorescence

- Generally cyme and terminal

- 5 free (not fused) sepals, $1 \frac{1}{2}-11 \mathrm{~mm}$ long

- 5 petals, .6-9 mm long, entire

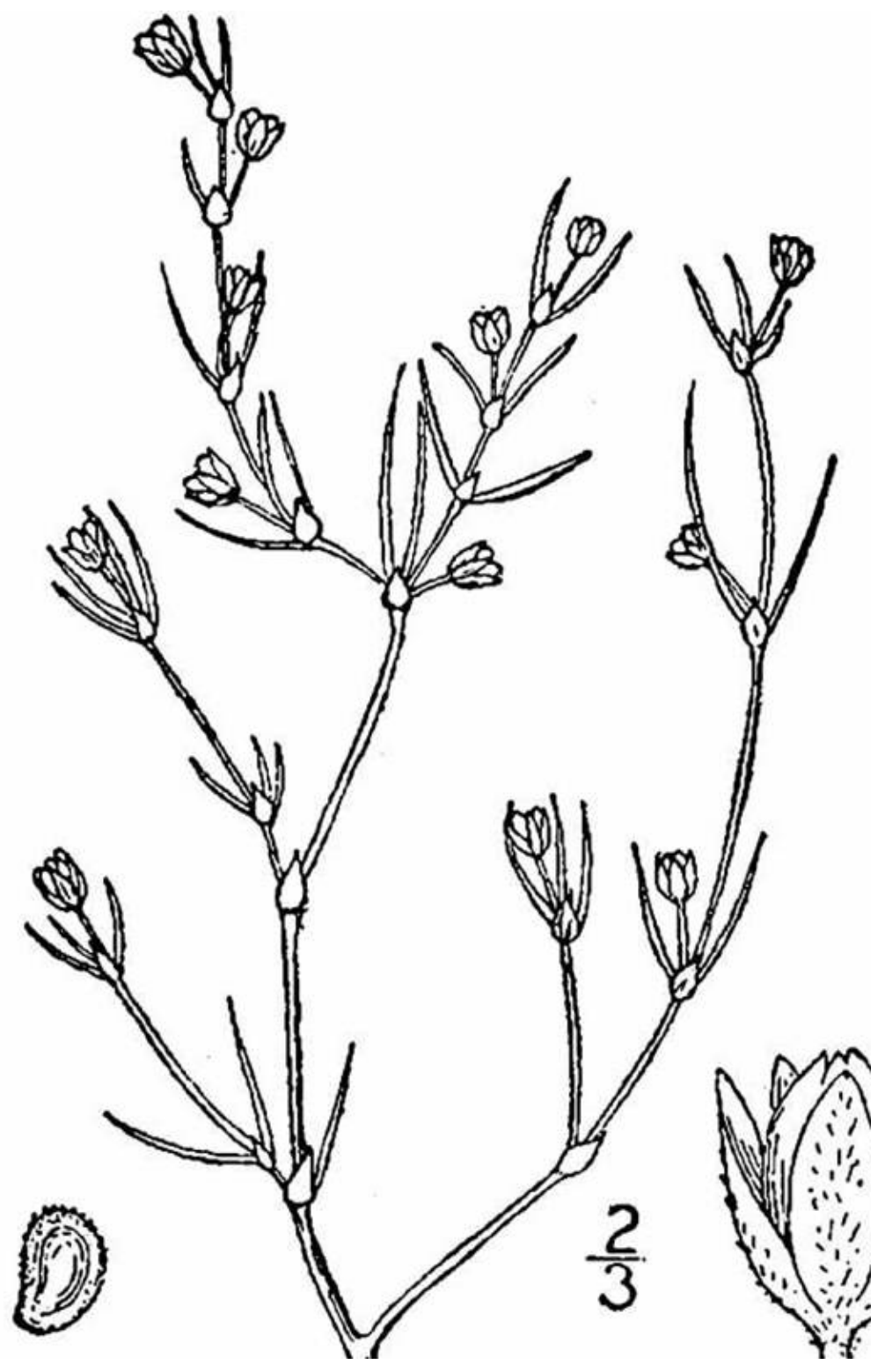

Spergularia salina

1913 Britton, N.L. and A. Brown

USDA-NRCS PLANTS Database

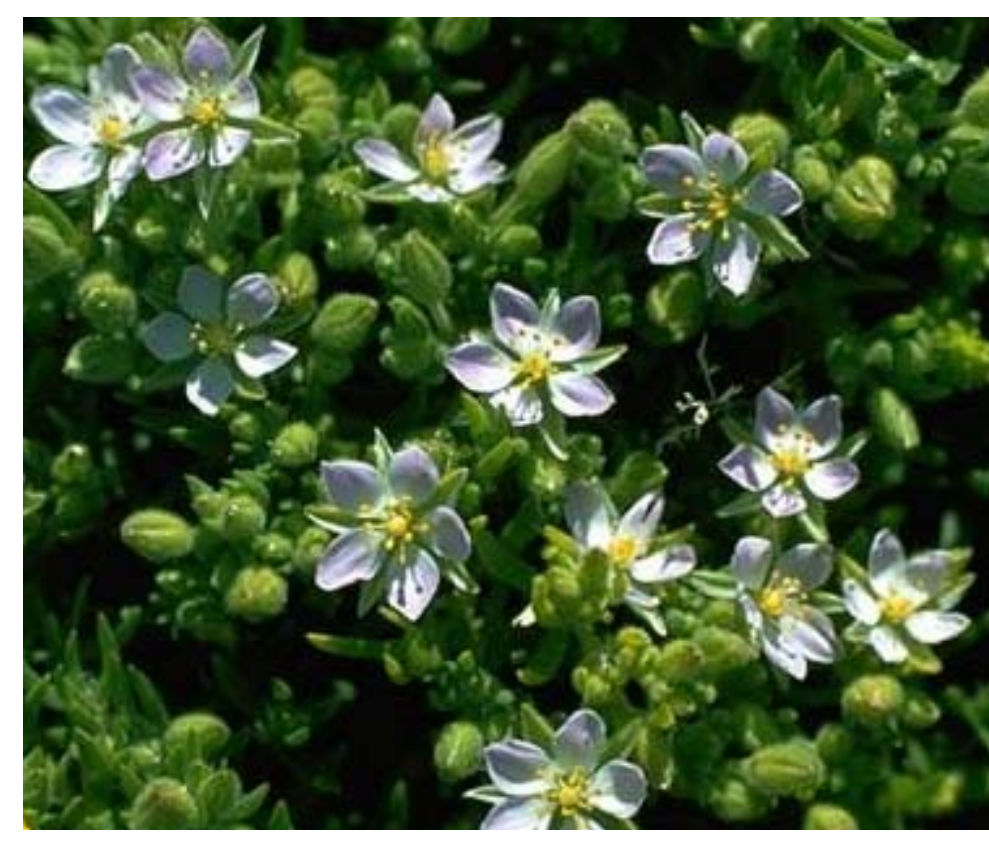

Spergularia macrotheca

(C) 1995 Saint Mary's College of California

Br. Alfred Brousseau, photographer

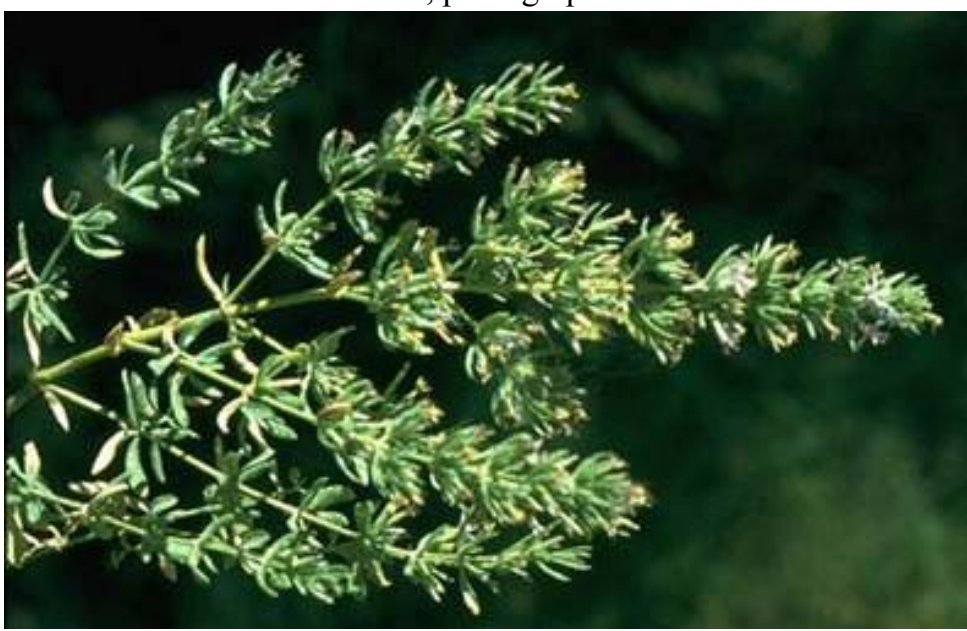

Spergularia rubra

(C) 1995 Saint Mary's College of California

Br. Alfred Brousseau, photographer

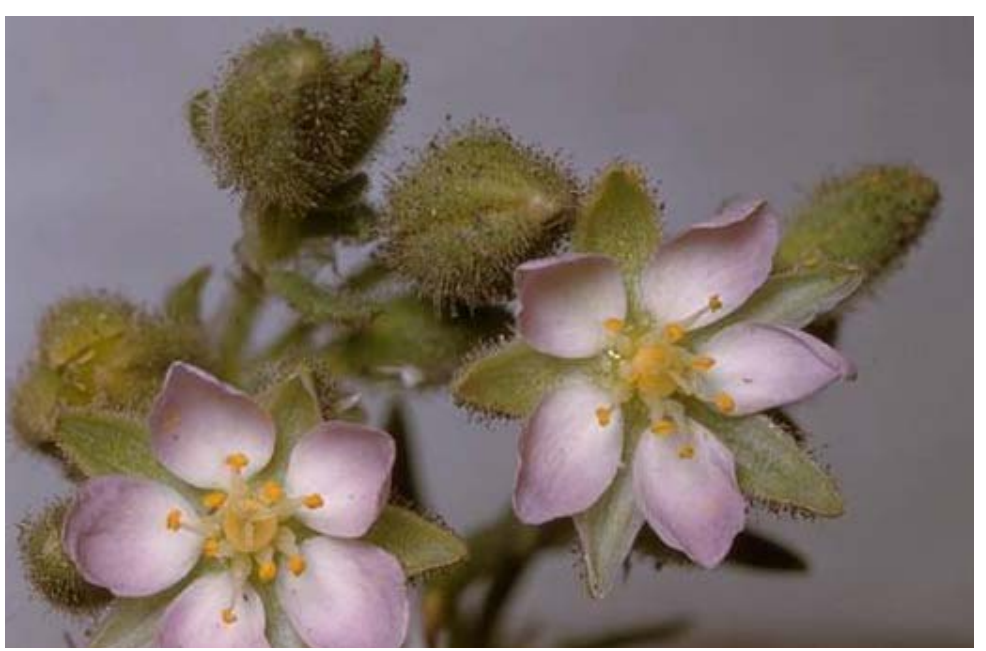

Spergularia macrotheca

C 1998 California Academy of Sciences

Charles Webber, photographer 
Sporobolus airoides (Alkali sacaton)

- Native perennial

Stems

- Ascending to erect, bunched at base

- $3-20 \mathrm{dm}$

Leaves

- Rolled, drooping, narrow and pointed

- Sheaths may be smooth or hairy

- Ligules less than $1 / 2 \mathrm{~mm}$ and fringed

- Blades 12-40 cm long, 2-4 mm wide Inflorescence (May-October)

- Generally terminal, 1-6 dm

- Base 4-25 cm wide

- Panicle, pyramid-shaped

- Each spikelet is 1-3 mm and contains a single floret

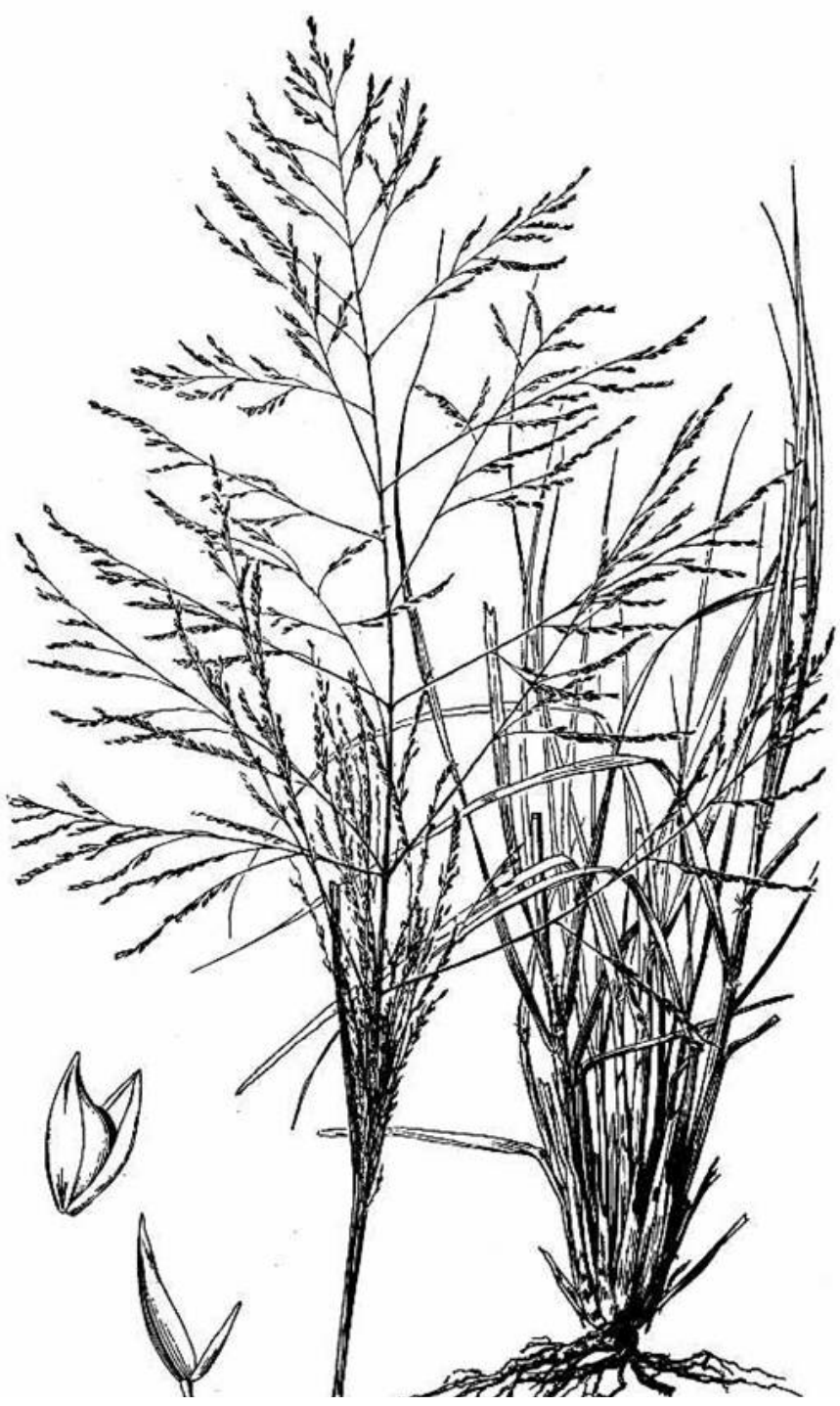

1950 A.S. Hitchcock

USDA-NRCS PLANTS Database

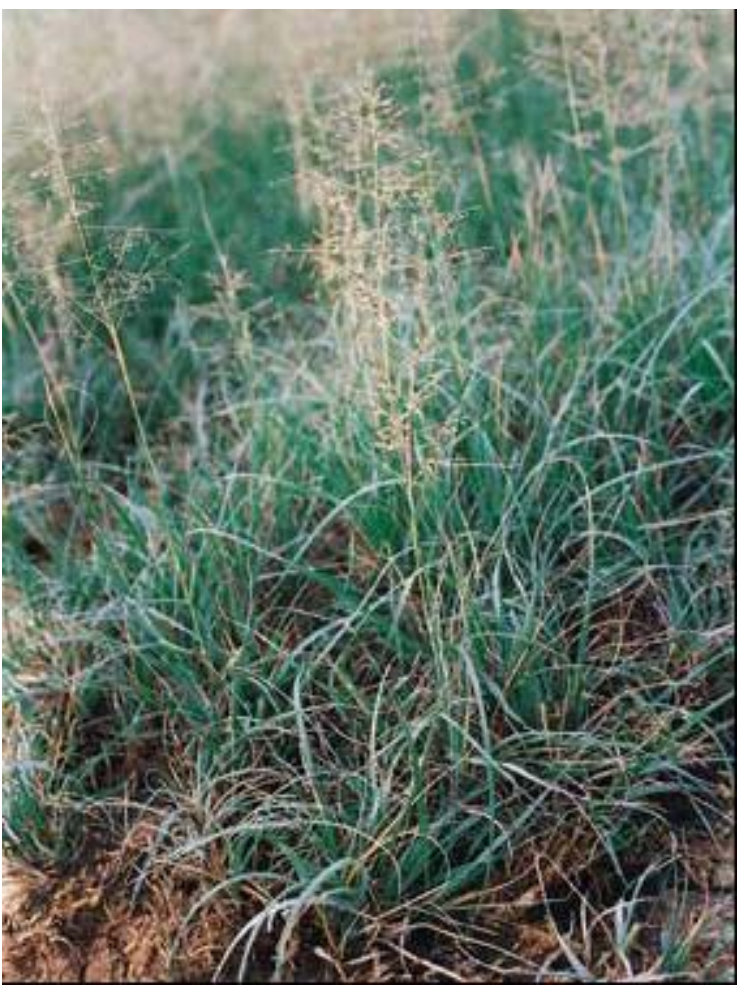

(C) 2004 The Samuel Roberts Noble Foundation, Inc.

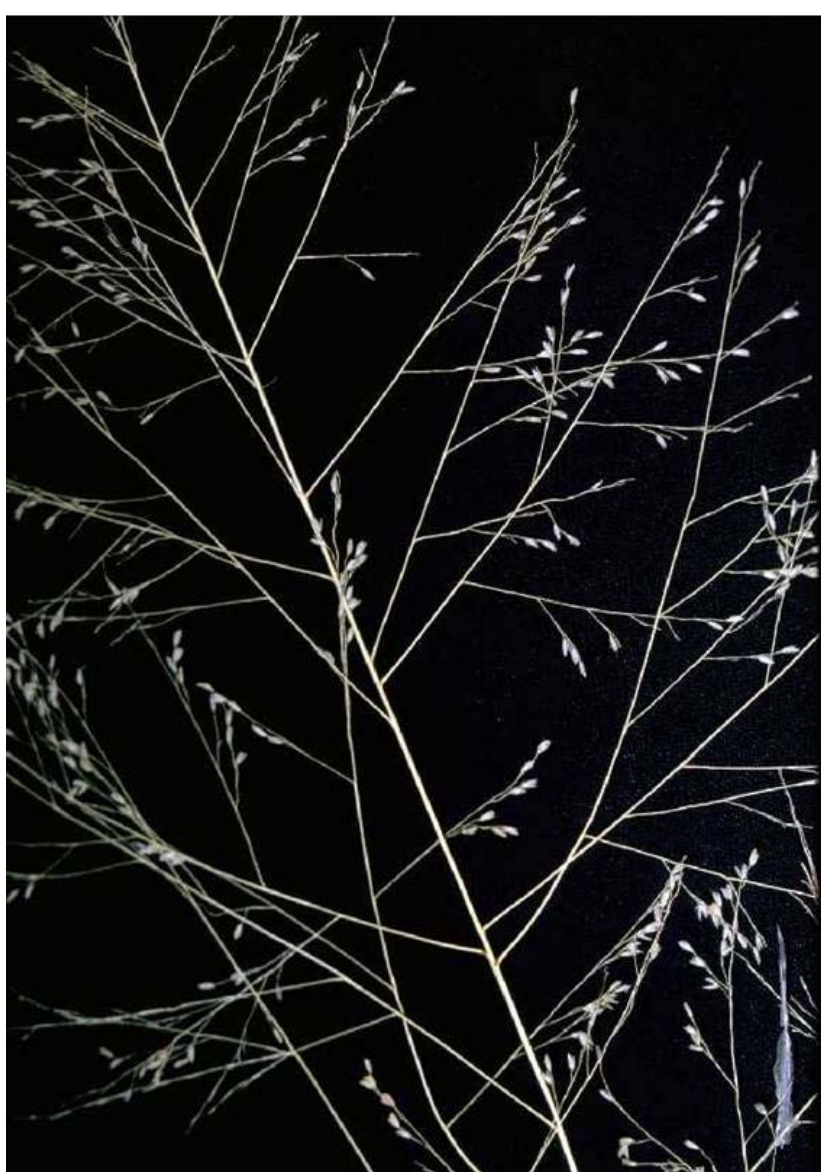

Robert H. Mohlenbrock

USDA-NRCS PLANTS Database 
Typha spp. (Cattail)

- Native perennial

- Up to $3 \mathrm{~m}$ tall

- May grow in water $1 \mathrm{~m}$ deep

Stems Leaves

- Upright, simple and hard

- Ribbon like, flat, and about $2 \frac{1}{2} \mathrm{~cm}$ wide

- Sheath open, blade linear Inflorescence

- $\quad$ Spike-like, terminal, cylindrical

- On stalks that are usually taller than the leaves

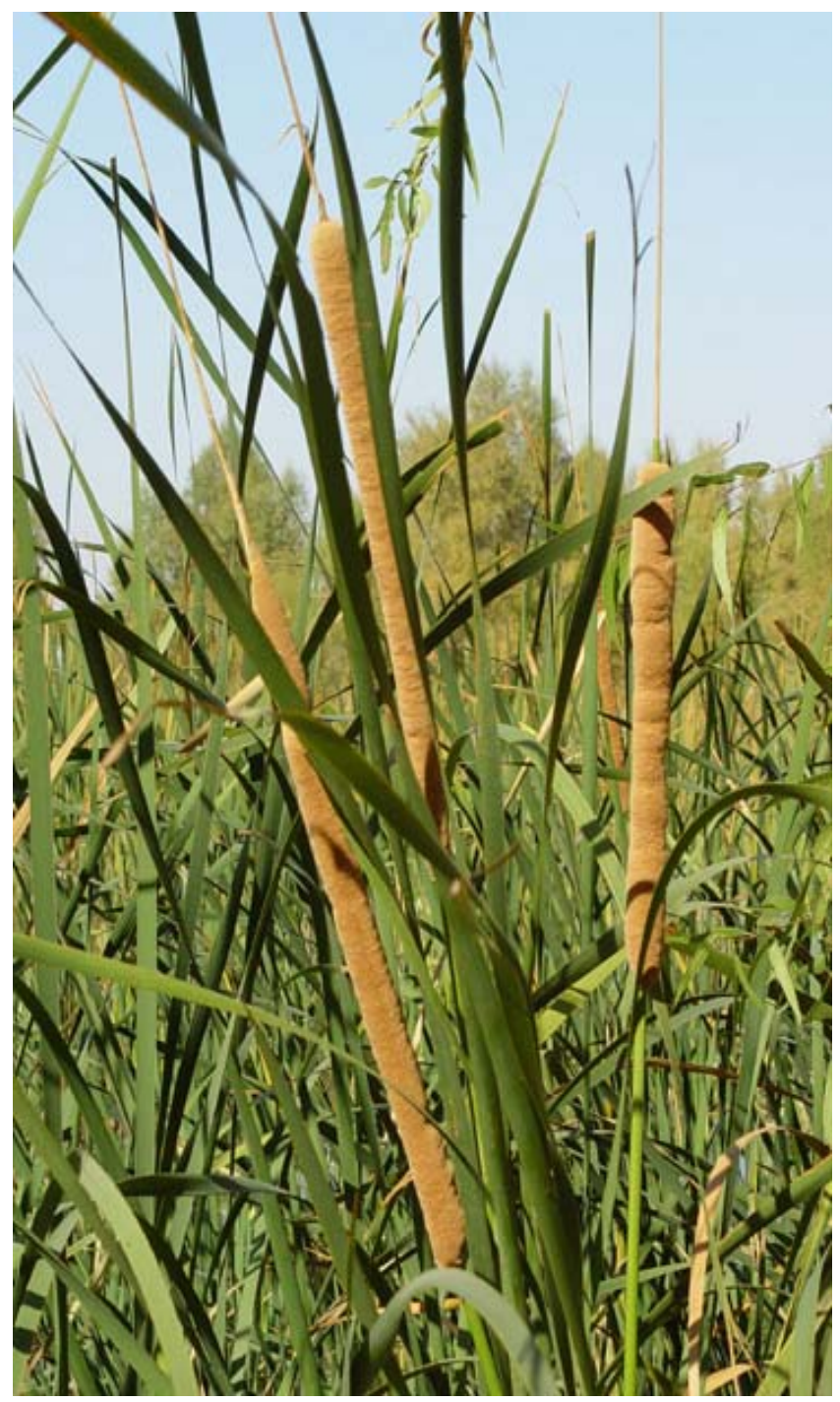

Typha latifolia

(C) 2003 George W. Hartwell



Typha domingensis

C Larry Allain

USDA-NRCS PLANTS Database

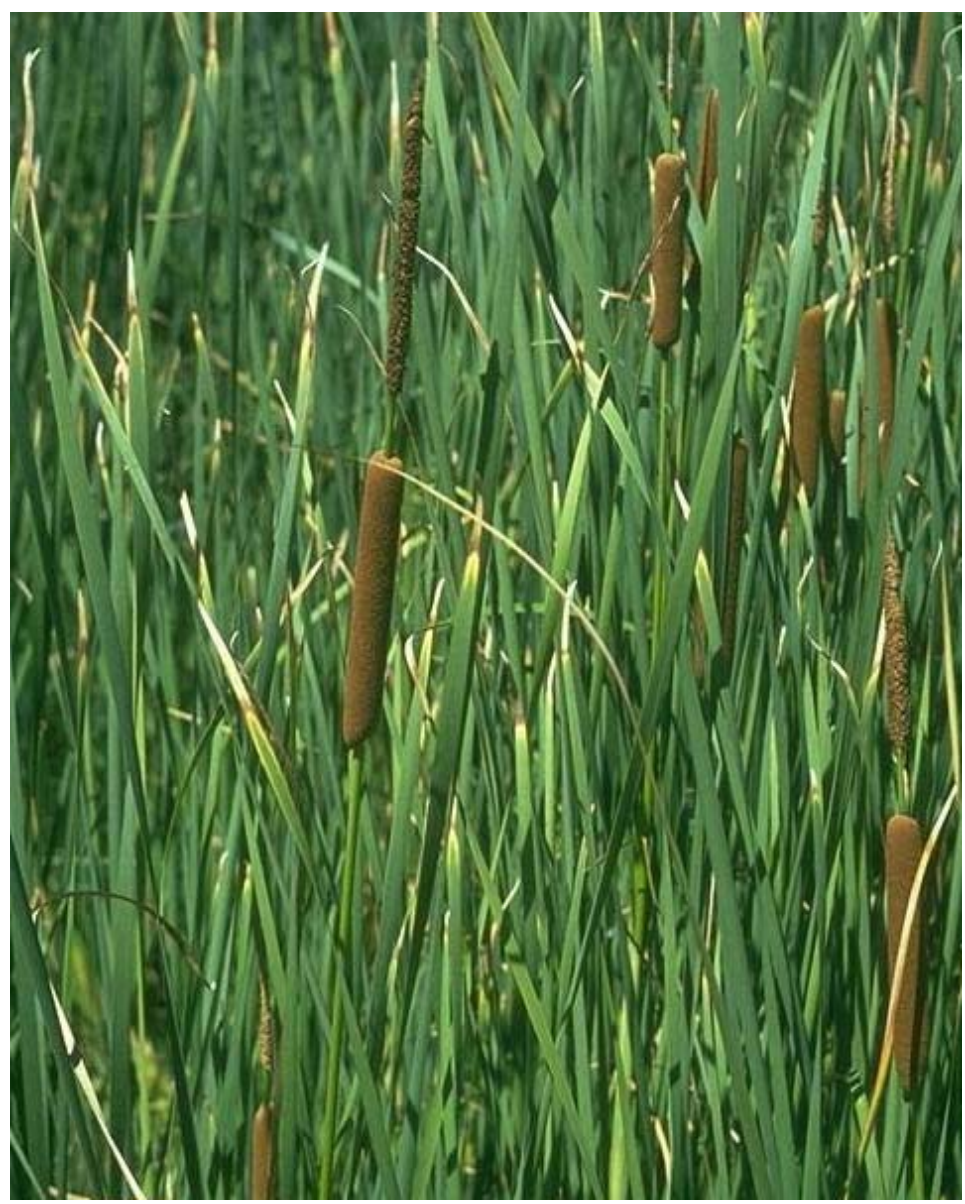

Typha domingensis

(C) 1995 Saint Mary's College of California Br. Alfred Brousseau, photographer 


\section{Xanthium strumarium (Cocklebur)}

\section{Stems}

- Up to $15 \mathrm{dm}$ long

- Generally thick and fleshy with black or red spots

Leaves

Without prickles, spines or thorns

- Blades less than $15 \mathrm{~cm}$ long

- Long petioles, widely triangular, 3-lobed and coarsely toothed

Inflorescence

- Clusters of green male flowers at the top

- Female flowers occur in burs on short stalks where the leaf axils meet the stem

- Each bur contains two flowers, and is oval-shaped with a pair of beak-like hooks

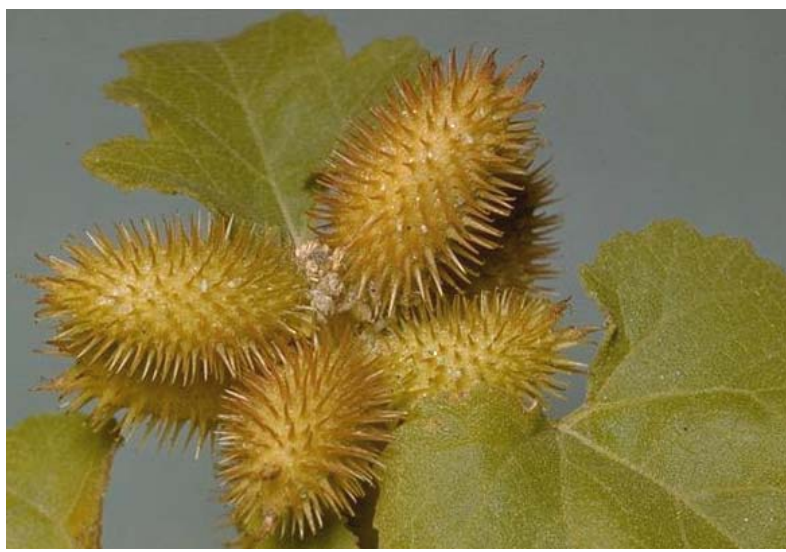

C 1998 California Academy of Sciences Charles Webber, photographer

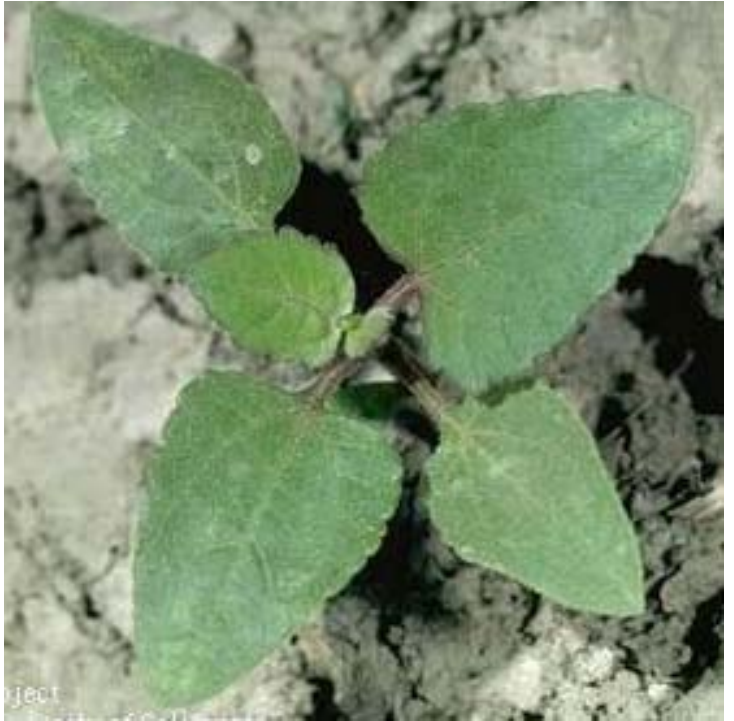

(C) 2000 Regents, University of California UC Statewide IPM Program Jack Kelly Clark, photographer

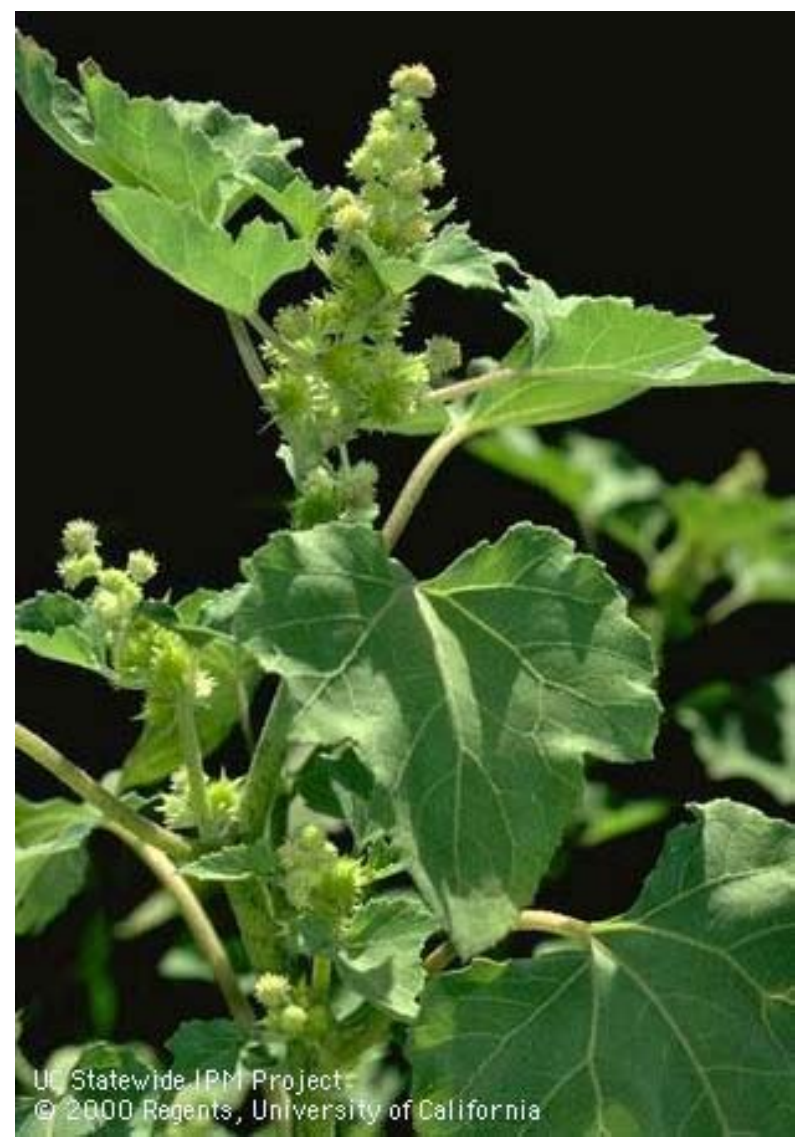

Jack Kelly Clark, photographer

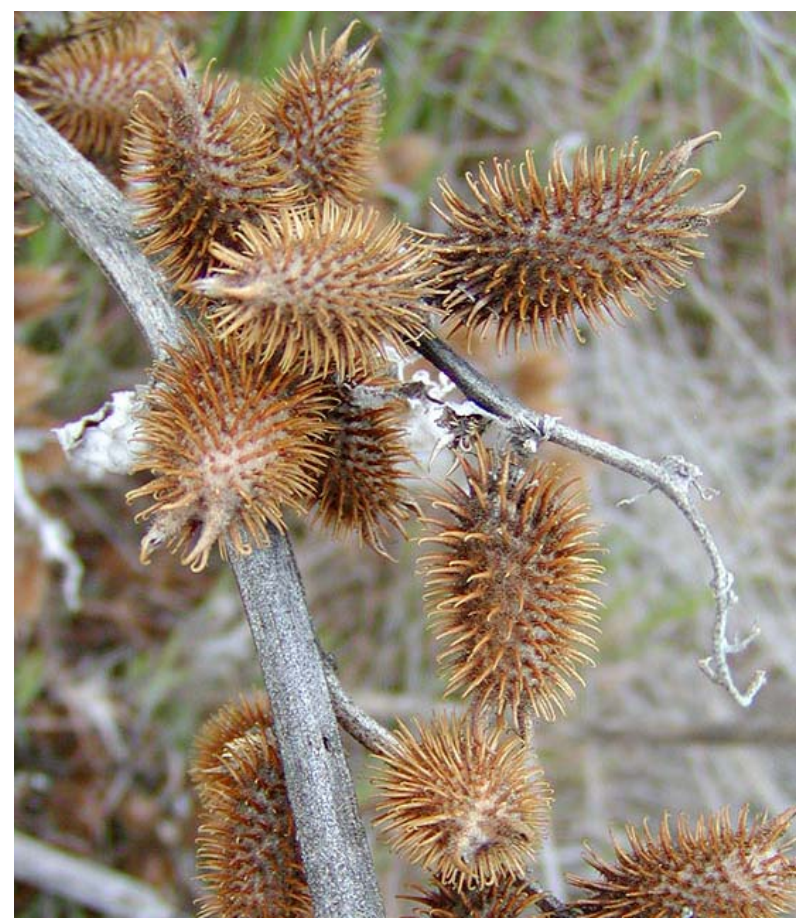

(C) 2003 BonTerra Consulting 


\section{ILLUSTRATIONS}

\section{A Grass Plant}
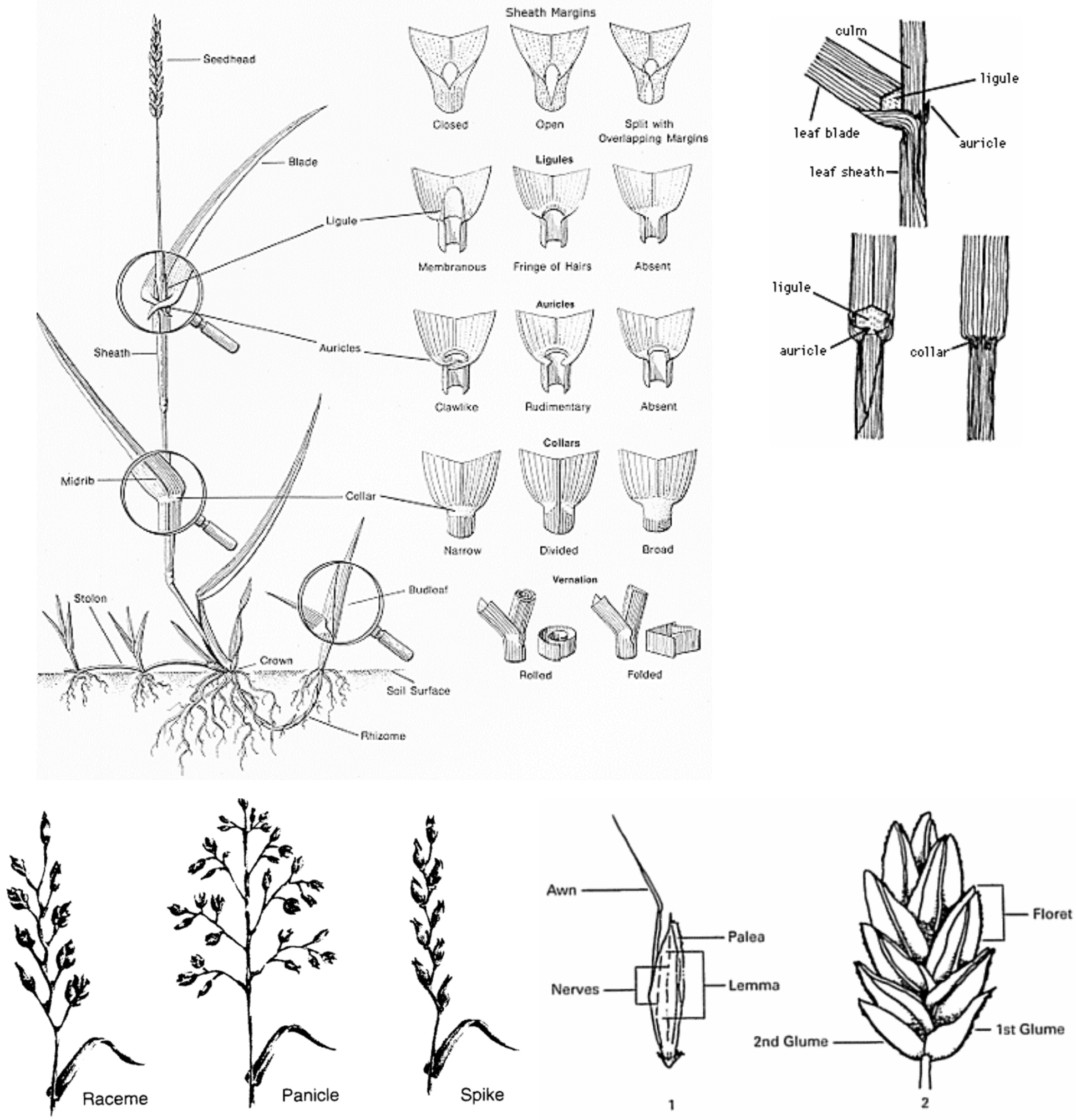

Inflorescence types

Figure 3.17 Grass spikelet and floret: (1) floret: (2) spikelet. 

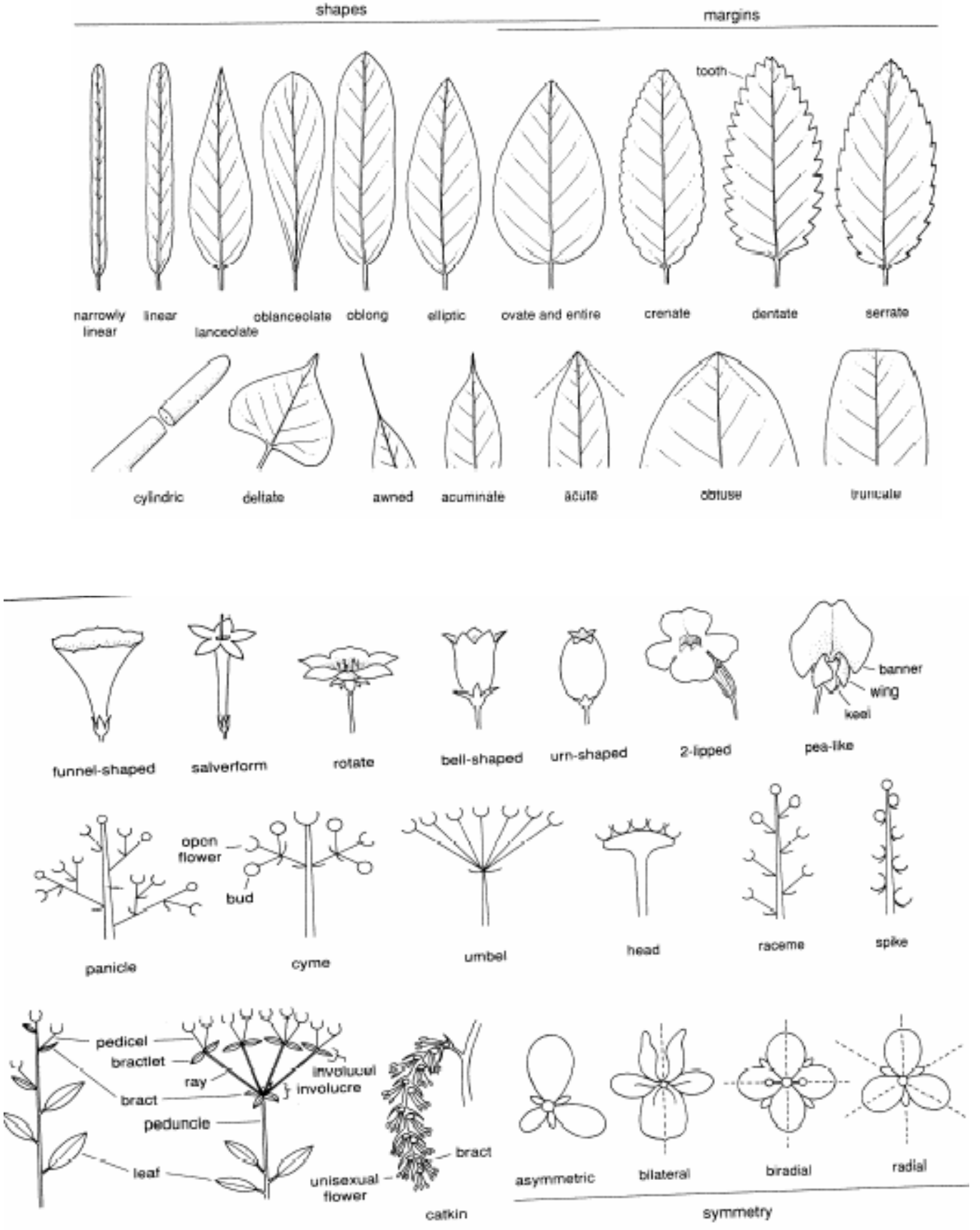


\section{PLANT TERMS}

Acuminate - (adj.) having a long-tapered, sharp tip, the sides of which are concave. See leaf sketches.

Auricle - (n.) any ear-like lobed appendages. See grass illustrations.

Awn - (n.) a stiff, bristle-like appendage, usually at the end of a structure. See grass illustrations.

Bract - (n.) a modified leaf, growing at the base or on the stalk of a flower. It usually differs from the other leaves in shape, size or color. See inflorescence sketches.

Cauline - (adj.) borne on a stem; not basal. Said especially of leaves borne along an aboveground stem.

Collar - (n.) region between blade and leaf sheath of grasses. See grass illustrations.

Cyme - (n.) a cluster of flowers in which each main and secondary stem bears a single flower, the bud on the main stem blooming first; determinate inflorescence in which each growing point ends in a flower. See inflorescence sketches.

Decumbent - (adj.) trailing on the ground and rising at the tip, as some stems.

Decurrent - (adj.) extending downward, applied usually to leaves in which the blade is apparently prolonged downward as two wings along the petiole or along the stem.

Dentate - (adj.) having margins with sharp, relatively coarse teeth pointing outward, not tipward. See leaf sketches.

Fascicle - (n.) a small bundle or tuft, as of fibers, leaves, etc.

Floret - (n.) one of the small individual flowers of a crowded inflorescence; flower with lemma and palea, of grasses.

Glaucous - (adj.) covered with a generally whitish or bluish, waxy or powdery film that is sometimes easily rubbed off.

Glume - (n.) generally two sheathing bracts that are the lowermost parts of a spikelet. See grass illustrations.

Hypanthium - (n.) structure derived from the fused lower portions of sepals, petals and stamens and from which these parts seem to arise, the whole generally in the shape of a tube, cup or plate.

Internode - (n.) the portion of a stem between nodes.

Lanceolate - (adj.) shaped like a lance; broadest toward the base and narrowed to the apex several times longer than wide. See leaf sketches.

Ligulate - (adj.) In Asteraceae, a bixexual, bilateral flower with the long, outer portion of the corolla (called the ligule) 5-lobed. Appears only with other ligulate flowers in a ligulate head. 
Ligule - (n.) in grasses or other grass-like plants, an appendage at the juncture of leaf sheath and blade, generally with a membranous or fringed margin. See grass illustrations.

Node - (n.) joint of a stem from which leaves, roots, shoots, or flowers may arise. A node will contain one or more buds.

Oblanceolate - (adj.) a leaf shaped like a lance point reversed, that is, having the tapered point next to the leafstalk. See leaf sketches.

Palmate - (adj.) radiating from a common point. Generally said of veins, lobes, or leaflets of a leaf.

Panicle - (n.) a branched racemose inflorescence often applied more widely to any branched inflorescence. See inflorescence sketches.

Papillate - (adj.) bearing small, rounded or conic protuberances (papillae). Said especially of a leaf or fruit surface.

Petiole - (n.) leaf stalk, connecting leaf blade to stem

Pinnate - (adj.) feather-like, with two rows of structures on opposite sides of an axis. Generally said of veins, lobes, or leaflets arranged in two dimensions along either side of an axis. A leaf is odd-pinnate if there is a terminal leaflet, even-pinnate if there is not, and either may be 1pinnate (blade divided into primary leaflets), 2-pinnate (primary leaflets divided into secondary leaflets), etc.

Puberulent- (adj.) having hairs normally visible only when magnified.

Pubescent- (adj.) a general term for hairiness; covered with soft hair or down.

Racemose - (adj.) an inflorescence whose growing points continue to add to the inflorescence and in which there are no terminal flowers, and the branching is monopodial, as racemes, or spikes.

Ray - (n.) a primary, radiating axis, as a primary branch in a compound umbel; the stalk of an individual flower or fruit.

Rhizome - (n.) a subterranean horizontal root-like stem sending out leaves and shoots from its upper surface and roots from its lower surface. See grass illustrations.

Scabrous - (adj.) rough to the touch, generally owing to short stiff hairs.

Scarious - (adj.) thin, dry, pliable, dark-colored or translucent but not green. Often like dry onion peel.

Sessile - (adj.) sitting directly on base without support, stalk, pedicel, or peduncle; attached or stationary as opposed to free living or motile. 
Sheath $-(n$.) a protective covering; lower part of leaf enveloping the stem. See grass illustrations.

Spike - (n.) a long flower cluster attached directly to the stalk. See inflorescence sketches.

Spikelet - (n.) a small spike of a large one; a subdivision of a spike; as the spikelets of grasses. See grass illustrations.

Stellate - (adj.) star-like. Generally said of a hair with three or more branches radiating from a common point.

Stolon - (n.) a stem that grows from a stem above the ground, taking root at the tip, and ultimately developing a new plant. See grass illustrations.

Terete - (adj.) nearly cylindrical in cross-section, as stems.

Tuber- (n.) (L. tuber, a swelling or knob on plants) the short, thickened fleshy food-storing portion of an underground stem with many surface buds, generally shaped like a rounded protuberance.

Urn-shaped- (adj.) pertaining to a fused calyx or corolla that is gradually or abruptly narrowed toward the tip. See inflorescence sketches. 


\section{REFERENCES}

Arizona State University Vascular Plant Herbarium. 2003. (http://svl.la.asu.edu/herbarium/)

Fagg, M. 2003. Australian National Botanic Gardens website. (http://www.anbg.gov.au/anbg).

Britton, N.L., and A. Brown. 1913. Illustrated flora of the northern states and Canada. Vol. 1: 190.

The CalFlora Database Project. 2003. (http://www.calflora.org/)

California Dept. of Food \& Agriculture, Botany Laboratory. 2001.

Charters, Michael L. 2003. (http://www.calflora.net/)

Cole, Peter. 1996. A Botanical Glossary. (http://www.flytrap.demon.co.uk/cpgloss.htm)

Haarstad, John A. and Delaney, Barbara C. 1999.

(http://cedarcreek.umn.edu/flora/plantcover.html)

Hickman, James C. 1993. The Jepson Manual: Higher Plants of California. University of California Press, Berkeley, CA.

Haddock, Mike. 2002. (http://www.lib.ksu.edu/wildflower/)

Hitchcock, A.S. (rev. A. Chase). 1950. Manual of the grasses of the United States. USDA Misc. Publ. No. 200. Washington, DC.

Julie S. 2001. Botany World.com the Encyclopedia of Plants. (http://www.botanyworld.com)

Kozak, Chuck. 1998-2003. Native Plants of Montara Mountain website.

(http://plants.montara.com/)

Manhart, James. 2003. Texas A\&M University Department of Biology.

(http://www.iisgcp.org/EXOTICSP/)

Missouri Botanical Garden. 2003. (http://www.mobot.org/)

Mohlenbrock, Robert H. 1989. Midwest wetland flora: Field office illustrated guide to plant species. Midwest National Technical Center, Lincoln, NE.

National Museums and Galleries of Northern Ireland and Environment and Heritage Service. 2000-2004. (http://www.habitas.org.uk/flora/index.html)

The Nature Conservancy. 2003 Wildland Invasive Species Team (http://tncweeds.ucdavis.edu/photosa-c.html)

Ohio State University. 2004. Agricultural and Research Development Center. (http://www.oardc.ohio-state.edu/weedguide/listall.asp) 
Oregon State University, Weed Science Program. 2000.

(http://cropandsoil.oregonstate.edu/weeds)

Parker, Reny. 2001-2002. Wildflowers - A Closer Look. (www.renyswildflowers.com)

The Samuel Roberts Noble Foundation, Inc. 2004. (http://www.noble.org/Index.html)

Sutton, David. 1999. (http://aquat1.ifas.ufl.edu/glossary.html)

Tenaglia, Dan. 2003. Missouri Flora Website. (http://www.missouriplants.com/)

University of California, Berkeley. Digital Library Project. (http://elib.cs.berkeley.edu/)

University of California, Hastings Natural History Reservation

University of California Statewide Integrated Pest Management Program. 2003.

(http://www.ipm.ucdavis.edu)

University of Florida. 2001. Center for Aquatic and Invasive Plants. (http://plants.ifas.ufl.edu/)

University of South Florida. 2002. Institute for Systematic Botany.

(http://www.plantatlas.usf.edu/)

University of Tennessee Herbarium and Austin Peay State University. 2004.

(http://tenn.bio.utk.edu/vascular/vascular.html)

University of Wisconsin, Madison Herbarium. 2003. (http://www.botany.wisc.edu/herbarium/)

USDA Forest Service Collection. (http://huntbot.andrew.cmu.edu/USDA/USDA-Drawings$\underline{\text { 08.html) }}$

USDA-NRCS, 2003. The PLANTS Database (http://plants.usda.gov/plants). National Plant Data Center, Baton Rouge, LA 70874-4490 USA.

USGS. 2002. Western Wetland Flora Field Office Guide to Plant Species

(http://www.npwrc.usgs.gov/resource/othrdata/westflor/species.htm). Northern Prairie Wildlife

Research Center.

Virginia Tech Department of Plant Pathology, Physiology \& Weed Science. Virginia Tech Weed Identification Guide. (http://www.ppws.vt.edu/weedindex.htm)

Wisconsin Department of Natural Resources. Wisconsin Plant of the Week. 2002. (http://www.klines.org/joanne/index.html) 